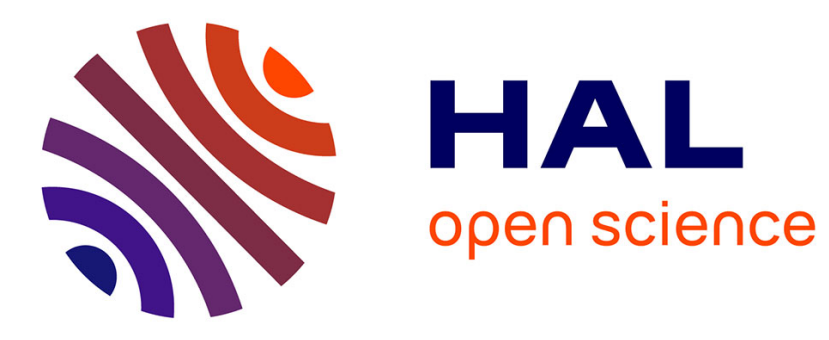

\title{
Molecular phylogeny and revised classification of the Buccinoidea (Neogastropoda)
}

\author{
Yuri I Kantor, Alexander E. Fedosov, Alisa R Kosyan, Nicolas Puillandre, \\ Pavel Sorokin, Yasunori Kano, Roger Clark, Philippe Bouchet
}

\section{- To cite this version:}

Yuri I Kantor, Alexander E. Fedosov, Alisa R Kosyan, Nicolas Puillandre, Pavel Sorokin, et al.. Molecular phylogeny and revised classification of the Buccinoidea (Neogastropoda). Zoological Journal of the Linnean Society, In press, 10.1093/zoolinnean/zlab031 . hal-03321428

\section{HAL Id: hal-03321428 \\ https://hal.science/hal-03321428}

Submitted on 17 Aug 2021

HAL is a multi-disciplinary open access archive for the deposit and dissemination of scientific research documents, whether they are published or not. The documents may come from teaching and research institutions in France or abroad, or from public or private research centers.
L'archive ouverte pluridisciplinaire HAL, est destinée au dépôt et à la diffusion de documents scientifiques de niveau recherche, publiés ou non, émanant des établissements d'enseignement et de recherche français ou étrangers, des laboratoires publics ou privés. 


\section{LINNEAN ZOCIETY ZOOLOGICAL -

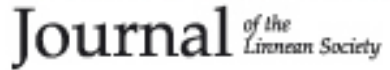

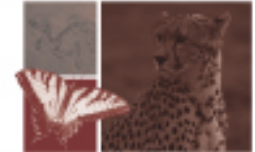

\section{Molecular phylogeny and revised classification of the Buccinoidea (Neogastropoda)}

\begin{tabular}{|c|c|}
\hline Journal: & Zoological Journal of the Linnean Society \\
\hline Manuscript ID & ZOJ-01-2021-4449.R1 \\
\hline Manuscript Type: & Original Article \\
\hline Keywords: & $\begin{array}{l}\text { anatomy < Anatomy, Bayesian inference }<\text { Phylogenetics, zoogeography } \\
<\text { Geography, shell morphology < Anatomy, COI mtDNA < Genetics, } \\
\text { molecular phylogeny < Genetics }\end{array}$ \\
\hline Abstract: & $\begin{array}{l}\text { The superfamily Buccinoidea is distributed in the world's oceans from the } \\
\text { Arctic Ocean to the Antarctic, from intertidal to abyssal depths. It } \\
\text { encompasses about } 3,340 \text { Recent species in } 337 \text { genera. The latest } \\
\text { taxonomic account recognized eight full families. For the first time the } \\
\text { monophyly of the superfamily and the relationships among the families } \\
\text { are tested with molecular data supplemented by anatomical and radula } \\
\text { data. Five genetic markers were used: fragments of mitochondrial cox } 1 \text {, } \\
16 \mathrm{~S} \text { rRNA, } 12 \mathrm{~S} \text { rRNA, and nuclear H3 and } 28 \mathrm{~S} \text { rRNA genes (for } 225 \\
\text { species of } 117 \text { genera). Our analysis recovered Buccinoidea } \\
\text { monophyletic in the Bayesian analysis. The relationships between the } \\
\text { formerly recognized families and subfamilies are drastically revised and a } \\
\text { new classification of the superfamily is here proposed, now including } 20 \\
\text { taxa of family rank and } 23 \text { subfamilies. Five new families (Eosiphonidae, } \\
\text { Retimohniidae., Chauvetiidae, Dolicholatiridae, Prodotiidae) and one } \\
\text { subfamily of Nassariidae (Tomliniinae) are described. Austrosiphonidae } \\
\text { and Tudiclidae are resurrected from synonymy and employed in a new } \\
\text { taxonomical extension. All but } 37 \text { recent genera are reclassified. Our } \\
\text { results demonstrate that anatomy is rather uniform within the } \\
\text { superfamily. With exceptions, the rather uniform radular morphology } \\
\text { alone does not allow allocating genera to a particular family without } \\
\text { additional molecular data. }\end{array}$ \\
\hline $\begin{array}{r}\text { AUTHORS: Yuri I Kantor, } \\
\text { Pavel A. Sorok }\end{array}$ & $\begin{array}{l}\text { Alexander E. Fedosov, Alisa R. Kosyan, Nicolas Puillandre, } \\
\text { kin, Yansunori Kano, Roger Clark, Philippe Bouchet }\end{array}$ \\
\hline
\end{tabular}


1 Abstract.

2 The superfamily Buccinoidea is distributed in the world's oceans from the Arctic Ocean to the 3 Antarctic, from intertidal to abyssal depths. It encompasses about 3,340 Recent species in 337 4 genera. The latest taxonomic account recognized eight full families. For the first time the monophyly of the superfamily and the relationships among the families are tested with molecular data supplemented by anatomical and radula data. Five genetic markers were used: fragments of mitochondrial cox1, 16S rRNA, 12S rRNA, and nuclear H3 and 28S rRNA genes (for 225 species of 117 genera). Our analysis recovered Buccinoidea monophyletic in the Bayesian analysis. The relationships between the formerly recognized families and subfamilies are drastically revised and a new classification of the superfamily is here proposed, now including 20 taxa of family rank and 23 subfamilies. Five new families (Eosiphonidae, Retimohniidae., Chauvetiidae, Dolicholatiridae, Prodotiidae) and one subfamily of Nassariidae (Tomliniinae) are described. Austrosiphonidae and Tudiclidae are resurrected from synonymy and employed in a new taxonomical extension. All but 37 recent genera are reclassified. Our results demonstrate that anatomy is rather uniform within the superfamily. With exceptions, the rather uniform radular morphology alone does not allow allocating genera to a particular family without additional molecular data.

Zoobank registration: To be added after reviews. 


\section{INTRODUCTION}

The superfamily Buccinoidea is one of the largest and most successful groups of Neogastropoda. It currently encompasses 3,351 accepted Recent species classified in 337 genera (MolluscaBase, 2020, accessed 19/12/2020). Among neogastropods, only the superfamily Conoidea, with 5,267 described Recent species and 379 genera (MolluscaBase, 2020, accessed 19/12/2020), outnumbers Buccinoidea in taxonomic diversity.

Buccinoidea are distributed from the Arctic Ocean to the Antarctic, from the intertidal to depths of more than 8,000 $\mathrm{m}$ (Kantor et al., 2020b), and include several genera penetrating brackish waters and even freshwater (Strong et al., 2017). They exhibit a broad range of feeding ecologies: while a majority are carrion feeders, scavengers or active predators (Taylor et al., 1980), some have transitioned to herbivory (some Nassariidae and Columbellidae; Brown, 1969, Marcus \& Marcus, 1962); one lineage of buccinids is composed exclusively of specialized dwellers of biogenic substrates and hot vents (Kantor et al., 2013); members of the Colubrariidae, known as vampire snails, suck blood from sleeping fishes (Bouchet \& Perrine, 1996; Oliverio \& Modica, 2010); and at least some species of the enigmatic genus Chauvetia have been found in association with starfishes (Oliver \& Rolan, 2008). A number of buccinoidean species are the target of commercial fisheries in northern Europe and the North Pacific, and several species have become model organisms for the study of gastropod embryology and development (e.g. Smith \& Thatje, 2013).

The superfamily has had a complex classification history, with as many as 57 family group names based on Recent genera currently attributed to the Buccinoidea. Thiele (1929) recognized five families within his "Stirps Buccinacea": Columbellidae, Buccinidae, Galeodidae [= Melongenidae], Nassidae [= Nassariidae], and Fasciolariidae. Essentially, this was the arrangement that prevailed during the subsequent decades, with some authors additionally recognizing a separate family Buccinulidae, which was erected mostly for Southern Hemisphere Buccinoidea (Finlay, 1928).

This taxonomic hierarchy was radically revisited by Golikov \& Starobogatov (1975), who raised the ranks of the taxa and recognized four superfamilies within the currently accepted extension of Buccinoidea: Fasciolarioidea, Buccinoidea (unexpectedly including, among others, the Vexillidae [= Costellariidae] and Pseudolividae), new superfamily Beringioidea, and Pyrenoidea. In total they recognized 10 families, two of which, Anachidae and Pyrenidae, were placed in different superfamilies but included genera currently classified in the family Columbellidae (see Table 1). These viewpoints were further developed in Golikov \& Starobogatov (1988), where these authors proposed a new classification of prosobranch gastropods at the rank of suborder and above. Their order Bucciniformes included the suborders Buccinoidei, Triphoroidei, Olivelloidei, and Muricoidei, while Pyrenoidei were classified in the order Mitriformes of the superorder Coniformii. Golikov and Starobogatov's classification with inflated ranks was barely followed or even discussed by subsequent authors, especially as Ponder and Warén (1988) simultaneously recognized only two families in the Buccinoidea: Columbellidae and Buccinidae (with the subfamilies Buccininae, Nassariinae, Melongeninae, Fasciolariinae), the latter including 29 synonyms, some of which were later excluded from the Buccinoidea (e.g., Dipsaccinae, now a synonym of Ancillariidae, Olivoidea; and Latrunculinae, now a synonym of Babyloniidae). 
The state of the art of Buccinoidea systematics, partly based on the molecular phylogenies then available, is that presented by Bouchet et al. (2017) (Table 1), who recognized eight families: Buccinidae (with six subfamilies and nine tribes), Belomitridae, Colubrariidae, Columbellidae (with two subfamilies), Fasciolariidae (with three subfamilies), Melongenidae, Nassariidae (with seven subfamilies), and Pisaniidae.

The recent molecular phylogenetic studies are, however, all partial and focused on individual families: Belomitridae (Kantor, Puillandre, Rivasseau \& Bouchet, 2012), Fasciolariidae (Couto et al., 2016), Nassariidae (Galindo et al., 2016), Colubrariidae (Oliverio \& Modica, 2010) or lower level taxa (Kantor et al., 2013; 2020a; 2020b), or even biogeographic assemblages (Vaux et al., 2017). The superfamily Buccinoidea in its entirety has in fact never been the subject of a comprehensive molecular phylogenetic analysis. As a consequence, in the absence of molecular data, the placement of many polar or temperate water lineages of the superfamily, such as the subfamily Beringiinae or the buccinid tribes Colini Gray, 1857, Volutopsiini Habe \& Sato, 1973 or Prosiphonini Powell, 1951, has remained tentative.

In the present study, we reconstruct a phylogeny of the Buccinoidea based on the analysis of an unprecedented dataset, comprising five molecular markers and a total of 116 genera and 231 species that cover rather comprehensively the geographic and taxonomic diversity of the superfamily. The outcome is a revised classification of the superfamily.

\section{MATERIAL AND METHODS}

\section{TAXON SAMPLING}

When assembling the dataset, we tried to include representatives of as many accepted and potentially valid family group taxa as possible. The core material for the present study was collected during several biodiversity surveys organized mainly by the Muséum National d'Histoire Naturelle (MNHN), Pro-Natura International (PNI) and the Institut de Recherche pour le Développement (IRD), as part of the Our Planet Reviewed and Tropical Deep-Sea Benthos programs (see Bouchet et al., 2008 and the BasExp database at http://expeditions.mnhn.fr/). Additional material was obtained from a number of museums, institutions and private sources (see list of repositories). A list of sequenced material included in the analysis, with collection details and not-aligned gene sequences, is provided in Suplementary material Table S1.

We generated original DNA sequence data or accessed published sequences for representatives of 28 nominal families and subfamilies of Buccinoidea (not counting the family group taxa introduced in this paper), but we lack members of the subfamilies Atiliinae Cossmann, 1901 (Columbellidae), Liomesinae P. Fischer, 1884, and Truncariinae Cossmann, 1901 (all probably Buccinidae).

Within the genus group, we consider only full genera. In total, we use in our analysis sequences (either original, or published) of 118 genera out of 339 , or $35 \%$ of the recognized diversity. Two families are particularly diverse at the genus level: Fasciolariidae (66 recognized genera, 17 of which are included in the current analysis) and Columbellidae (76 recognized genera, 6 included in the current analysis). The former was recently studied using molecular phylogenetic methods and found monophyletic (Couto et al., 2016), with the exception of several genera attributed herein to a separate family. The latter is currently being revised by E. Strong and M. deMaintenon and found monophyletic except one genus (personal 
communication) and is not treated here in detail. If we only consider buccinoidean genera outside these families (194 in total), our coverage reaches $48 \%$ of the recognized diversity.

A genus-level revision of the families of Buccinoidea is beyond the scope of the present work, since representatives of half of the valid genera were not available for molecular study and for some even the radula is unknown. So, no new genus names are proposed herein, even when an accepted genus is demonstrated to be non-monophyletic; these cases are, however, discussed in the remarks in the taxonomic treatment of individual families. Nevertheless, we attempt to allocate all known buccinoidean genera to the family group taxon as defined herein, based either on molecular and/or morphological data. Based on the data available, we use three levels of confidence for the allocation of a genus to a family group:

(1) genera classified in a family based on molecular and morphological data (mostly radula); marked ${ }^{(1)}-103$ genera;

(2) genera classified based on radula morphology only, and congruence between radula and molecular characters for those sequenced genera; marked ${ }^{(2)}-30$ genera.

(3) genera assigned to a family based on shell characters alone, and phenetic resemblance to those genera with radula and/or molecular characters available; marked ${ }^{(3)}-22$ genera.

36 genera were not attributed to any family with certainty, due to the lack of any radular or anatomical data, or when available data were deemed insufficient. For 27 of them, we nevertheless suggest a tentative classification (Suplementary material Table S2).

\section{SPECIMEN PROCESSING}

In the field, living specimens were anaesthetized with $\mathrm{MgCl}_{2}$ prior to fixation, or removed from their shells using a microwave oven following the protocol described by Galindo et al. (2014). Bodies were then separated from the shells, and shells were kept dry to prevent deterioration by etching and assigned the same registration number as the corresponding body (stored in 80-96\% ethanol) and tissue clip (stored in 96-98\% ethanol). Most of the material (shell, tissue and DNA) is vouchered in MNHN (http://science.mnhn.fr) unless otherwise stated.

Anatomy was examined by dissection. The bodies of some specimens were specially preserved in $80 \%$ ethanol after clipping a fragment of the foot for DNA extraction; others were preserved in $95 \%$ alcohol and briefly rehydrated (10-30 min) prior to dissection. In most cases this procedure allowed removal of the body from the shell and made tissues elastic enough for dissection. After dissection the bodies were returned to $95 \%$ ethanol. Radulae were cleaned using diluted bleach $(\mathrm{NaOCl})$, mounted on a glass cover slip or double-sided carbon tape, air-dried, attached to aluminium stubs, coated with gold and examined by scanning electron microscope TeScan TS5130MM in the IEE RAS.

For size characterization we used the following arbitrary divisions: shell small $<10 \mathrm{~mm}$, medium sized 10-29 mm; medium large, 30-100 mm; large, over $100 \mathrm{~mm}$.

\section{DNA EXTRACTION AND PCR}

Total DNA was extracted from a piece of foot using either the Dneasy96 Tissue kit (Qiagen) using automated extraction system Epmotion 5075 (Eppendorf), or manually, using Investigator Kit (Qiagen), following the manufacturer's recommendations. Five genetic markers were targeted for the phylogenetic reconstructions: the barcode fragment of the mitochondrial cytochrome $c$ oxidase I (coxl) gene ( $658 \mathrm{bp}$ ), a $\sim 450$-bp long fragment of the mitochondrial $16 \mathrm{~S}$ 
rRNA, a $\sim 550 \mathrm{bp}$ fragment of the mitochondrial 12S rRNA, a $328 \mathrm{bp}$ fragment of the nuclear Histone 3 (H3), and a 700 bp fragment of the nuclear 28S rRNA. The cox 1, 12S, H3 and 28S were amplified using the universal primers LCO1490 and HCO2198 (Folmer et al., 1994), 12SI and 12SIII (Simon et al., 1991), H3A-H3B (Colgan et al., 1998) and C1 and D2 (Jovelin \& Justine, 2001), respectively. The pair of primers DY16S748R (Hayashi, 2005) - 16sbr-H (Palumbi et al., 1991), the former developed specifically for Buccinidae, were used to amplify the 16S fragment. PCRs were performed in $20 \mu \mathrm{l}$ final volume containing approximately $3 \mathrm{ng}$ template DNA, $1.5 \mathrm{mM} \mathrm{MgCl} 2,0.26 \mathrm{mM}$ of each nucleotide, $0.3 \mu 1$ of each primer, $5 \%$ DMSO and $0.75 \mu \mathrm{l}$ of either Q-Bio-Taq Polymerase (Qbiogene) or BioHYTaq DNA polymerase (Dialat). The PCR profiles were as detailed in Fedosov et al. (2018) and Kantor et al. (2020). Success of amplification was checked using an electrophoresis in agarose gel; the obtained amplicons were purified by repeated precipitation in ethanol, or using Exo/SAP Go PCR Purification Kit (Grisp, Portugal) and sequenced in both directions. Sequencing was performed by Eurofins or at the joint usage centre 'Methods of molecular diagnostics' of the IEE RAS on an ABI 3500 Genetic analyser (Applied Byosystems).

\section{PHYLOGENETIC ANALYSIS}

Chromatograms were examined, and forward and reverse reads were merged into consensus sequences using a SeqMan Pro v11 of the DNASTAR package (Lasergene). Our dataset of 146 taxa with one specimen per species was complemented by previously published DNA sequences of 85 additional taxa of Buccinoidea or of other neogastropod lineages (Couto et al., 2016; Galindo et al., 2016; Fedosov et al., 2015, 2019; Kantor et al., 2012, 2013, 2020a, b; Oliverio \& Modica, 2010; Strong et al., 2017; Vaux et al., 2017; Zou et al., 2011), i.e. a total of 231 taxa, of which 222 were members of the superfamily Buccinoidea. Finally, only cox 1 sequences (11 accessed from GanBank and ten original) were used for 13 species in the analysis aiming at confirming the placement of particular taxa.

Sequences were aligned for each gene independently using MAFFT v.7 (Katoh et al., 2019). The accuracy of automatic alignments was confirmed by eye. No indels were detected in cox 1 and $\mathrm{H} 3$; various numbers of indels were identified in the $16 \mathrm{~S}, 12 \mathrm{~S}$ and $28 \mathrm{~S}$ fragments, leading to the alignments of 561, 607 and $745 \mathrm{bp}$ in length respectively. Alignments of 16S and $12 \mathrm{~S}$ contained regions with many indels, so we used GUIDANCE2 (Sela et al., 2015) to generate best alternative alignments for each of the two markers, and to remove ambiguously aligned bases. We removed alignment columns with confidence values below 0.4 , leading to alignments of 548 and 596 positions for $16 \mathrm{~S}$ and $12 \mathrm{~S}$ respectively, or, alternatively, below 0.9 , which resulted in the alignments of 471 and 475 positions for $16 \mathrm{~S}$ and $12 \mathrm{~S}$ respectively. For phylogenetic inference, eight datasets were analyzed. Five of them corresponded to the five individual genes and were analyzed separately to ensure that they did not result in supported conflicting topologies. Then three concatenated datasets of the five genes were built: Buc5G with entire lengths of $16 \mathrm{~S}$ and $12 \mathrm{~S}$ comprising 2,899 bp, and Buc5G_GUI40 and Buc5G_GUI90 with ambiguously aligned bases below confidence values 0.4 and 0.9 respectively removed from both $16 \mathrm{~S}$ and $12 \mathrm{~S}$, resulting in a total concatenated sequences lengths of $2,875 \mathrm{bp}$ and 2,677 bp respectively.

The single gene phylogenies were estimated by RAxML v.8.2.12 (Stamatakis, 2006), with ML (Maximum Likelihood) search and bootstrapping performed in a single run. The bootstrap 
seed value was set to 12345 , and robustness of nodes assessed by 1,000 iterations of rapid bootstrapping algorithm (Stamatakis et al., 2008).

The concatenated datasets were subdivided into seven partitions: three corresponding to three codon positions of the cox 1 , and the remaining four to the $16 \mathrm{~S}, 12 \mathrm{~S}, \mathrm{H} 3$ and $28 \mathrm{~S}$ fragments respectively. We avoided coding codon positions of $\mathrm{H} 3$ as separate partitions, because this fragment is rather short (328 bp), so estimating separate substitution statistics set for each codon position may lead to overparametralisation and reduced accuracy of the phylogenetic inference. Concatenated datasets were then analysed by ModelFinder implemented in IQ-Tree 2.1.1 (Kalyaanamoorthy et al., 2017) to identify the best fit nucleotide substitution model for each initial partition, and evaluate whether any initial partitions may be merged. Based on the obtained results, seven initial partitions were merged into two partitions, which were used for both RAxML (Maximum likelihood) and BI (Bayesian Inference).

The ML phylogenetic tree was reconstructed for the concatenated datasets using the same parameters of RAxML v.8.2.12 as were used for the single genes trees. Bayesian analysis (Huelsenbeck \& Ronquist, 2001) was performed on the concatenated datasets by running two parallel analyses in MrBayes with parameters of substitution models estimated during the run. Each run consisted of 25,000,000 generations of Markov chain, sampling frequency was set to one tree in each 1,000 generations, and chain temperature to 0.02 . Convergence of each analysis was evaluated using Tracer1.4.1 (Rambaut et al., 2014), where ESS (Effective Sampling Size) values were checked to ensure that they exceeded 200. A consensus tree was calculated after omitting the first $25 \%$ trees as burn-in. All analyses were performed on the Cipres Science Gateway (http://www.phylo.org/portal2), using IQ-Tree v. 2.1.1 on XSEDE, RAxML v.8.2.12 on XSEDE and MrBayes 3.2.6 on XSEDE (Miller et al., 2010).

The aligned datasets (cox-1 and concatenated five genes dataset) as well, as the details of the selected best models of nucleotide evolution and output consensus trees are provided as supplementary files (File S1 - File S10).

Nodes with Bootstraps values (B, in percent) lower than 70 and Posterior Probabilities (PP) lower than 0.95 are considered non-supported; B values between 70 and 90 and PP values between 0.95 and 0.98 are regarded as moderately supported; and B $>90$ and PP $>0.98$ as wellsupported.

\section{TURNING THE PHYLOGENY INTO A CLASSIFICATION}

Overall, a conservative approach was adopted and whenever possible we retained the current rank of the presently accepted family group taxa. As requested by the ICZN Code, we accepted available names even if they are based on genera considered to be junior synonyms. As much as possible, a genus-group name was applied based on the position of its type species in the tree. If the type species of a nominal genus or subgenus has not been sequenced, application of the name was determined by reference to the morphologically most similar species included in the molecular analysis.

Biogeographical regions follow Spalding et al. (2007), bathymetry ranges follow the 2009 UNESCO 2009 Global Open Oceans and Deep Seabed (GOODS) Biogeographic Classification.

REPOSITORIES AND ABBREVIATIONS:

AMS - The Australian Museum, Sydney, Australia; 
AORI - Atmosphere and Ocean Research Institute, University of Tokyo, Japan; Italy;

BAU - Dipartimento di Biologia Animale e dell'Uomo, 'La Sapienza' University, Roma,

$\mathrm{BI}$ - Bayesian inference analysis;

CSUF - California State University, Fullerton, CA, USA;

IEE RAS - A.N. Severtsov Institute of Ecology and Evolution, Russian Academy of Sciences, Moscow, Russia;

ICZN — International Code of Zoological Nomenclature;

$\mathrm{M}$ - by monotypy (with regard to the fixation of the type species of a genus);

ML - maximal likelihood analysis;

MNA - Italian National Antarctic Museum, section of Genoa, Italy;

MNHN — Muséum National d'Histoire Naturelle, Paris, France;

MCZ - Museum of Comparative Zoology, Harvard University, Cambridge, MA, USA;

MZUSP - Museum of Zoology, University of San Paulo, Brazil;

NHMUK - Natural History Museum, London, UK;

NMNZ - Museum of New Zealand Te Papa Tongarewa;

$\mathrm{OD}$ - by original designation (with regard to the fixation of the type species of a genus);

RNC - collection of R.N. Clark;

SFKH - Simon Hill collection, later transfeered to Te Papa Tongarewa Museum, Wellington, New Zealand;

SPSU - Saint Petersburg State university, Saint Petersburg Russia;

TS - type species;

ZIN - Zoological Institute, Russian Academy of Sciences, St. Petersburg, Russia;

ZSM - Bavarian State Collection of Zoology, München, Germany;

SD - by subsequent designation (with regard to the fixation of the type species of a genus);

SL — shell length.

\section{RESULTS}

\section{PHYLOGENETIC ANALYSIS}

All single gene analyses resulted in generally congruent trees. Support values were extremely low for deep nodes, but moderate to high for more recent nodes. Even in trees obtained from the analyses of concatenated datasets, most deep nodes are not resolved, or lack support.

Nevertheless, all four trees built from the analyses of the concatenated datasets display about the same set of well-supported clades, although (unsupported) relationships among them varied between the analyses.

Despite the low support values for deep nodes and some uncertain relationships, Buccinoidea was recovered as monophyletic in all analyses, but this node (Fig. 1) is only supported in the $\mathrm{BI}$ of the Buc5G dataset ( $\mathrm{PP}=0.97$ - Fig. 1). Altogether, this tree shows the highest support values and we mainly discuss the composition of revealed clades and relationships among them based on this tree, refererring to others when appropriate. On the contrary the trees obtained in the analysis of the Buc5G_GUI90 dataset displayed many polytomic nodes, with generally lower support, and will not be discussed further on. 
To discuss the topology of the obtained multigene tree, we select 31 highly or moderately supported clades, comprising all but seven analyzed species of Buccinoidea, which we refer to by the name of one included genus, whenever possible the type genus of a named family. On Figure 1, these clades are collapsed for a more convenient representation of the overall tree topology, and the unrestrained tree is provided in Figure 2. The first split in the Buccinoidea separates a well-supported grouping comprising two terminal clades, the Dolicholatirus-clade (comprising six species of the genera Dolicholatirus and Crassicantharus) and the Belomitraclade (with two species of the genus Belomitra). The grouping uniting the remaining Buccinoidea is highly supported in the analyses of the $\mathrm{Buc} 5 \mathrm{G}$ dataset $(\mathrm{B}=94, \mathrm{PP}=0.98)$ and is subdivided into two clades. The first of them, referred to on Figure 1 as CCBA (for Colubrariidae-Colidae-Biogenicsubstrates-Antarctic), comprises 1) Colubraria-clade (with six species representing five genera of the family Colubrariidae), 2) Colus-clade (comprising eight Arctic and northern Atlantic species of the genera Colus and Turrisipho), 3) large Eosipho-clade (encompassing 21 species of Buccinoidea from hydrothermal vents, methane seeps and sunken wood, currently classified in seven genera, with a sister group relationship with "Aulacofusus" hiranoi), and 4) Prosipho-clade (formed by 15 Antarctic and southern temperate water species currently assigned to nine genera within Buccinidae, including Austrofusus and, in part, Antarctodomus). The remaining Buccinoidea form a cluster, hereafter called core Buccinoidea, recovered in all analyses of multigene datasets, but with only moderate support in the ML analysis of the Buc5G dataset $(\mathrm{B}=87)$. The first major division within the core Buccinoidea unites the Siphonalia-clade (with 13 species currently attributed to five buccinid genera) and a large, maximally supported clade referred to as the Bu-grouping. The Bu-grouping itself encompasses five clades, among them the Volutopsius-clade (six species), Neptunea-clade (four species), Beringius-clade (five species), Bathyancistrolepis-clade (five species), and Buccinumclade (10 species). Relationships among the clades of the Bu-grouping remain unresolved, as does the placement of Anomalisipho verkruezeni within it. The second well-supported major division of the core Buccinoidea, referred to as the Fa-grouping, unites the Fusinus-clade (with 15 species representing five genera mostly of the fasciolariid subfamily Fusininae), Fasciolariaclade (comprising nine species of the fasciolariid subfamily Fasciolariinae), and Fusolatirus pearsoni in a sister relationship to the Fasciolaria-clade. The third well-supported division referred to as the PB-grouping comprises the Penion-clade (with nine species in four genera) and Buccinulum-clade (combining 17 species in the genera Buccinulum, Aenator, Tasmeuthria and Euthria, also mostly from the Southern Hemisphere).

Relationships among the other clades are either not consistently detected or lack support. Nevertheless, we mention here all divisions uniting two or more of the remaining 15 clades, and present in at least three multigene trees. The first such group, referred to as the BB-grouping, is well-supported in BI analyses of both the Buc5G_GUI40 and Buc5G datasets, but absent in the ML analysis of the Buc5G_GUI40 dataset. It unites the Busycon-clade (with three large species representing three genera from the tropical and temperate western Atlantic), Buccinanops-clade (comprising two species in the South American genus Buccinanops), and the East-Pacific species Macron lividus in a sister relationship with the Buccinanops-clade. The complex grouping referred to as the $\mathrm{NaCo}$-grouping (for Nassariidae-Columbellidae) is recovered in all multigene analyses but is never supported. It comprises the Columbella-clade (with seven species representing six genera of the family Columbellidae), and six terminal clades plus three species (for a total of 23 species), all currently classified in the family Nassariidae but consistently 
1 forming a grade in relation to the Columbella-clade. Four further clades show a consistent relationship to the $\mathrm{NaCo}$-grouping, but again without support and without consistent branching order. These are 1) the Melongena-clade (with three species representing three genera of the family Melongenidae), 2) Prodotia-clade (comprising four small Indo-Pacific species in the genera Prodotia, Caducifer and Clivipolia, previously attributed to the Pisaniidae); 3) large

6 Pisania-clade (including 14 species currently classified in six further genera of the Pisaniidae: Pisania, Engina, Hesperisternia, Cancellopollia, Cantharus and Pollia); and 4) Chauvetia-clade (with three species of the temperate Northern Atlantic genus Chauvetia). Finally, two small any of the above groups: 1) the Cominella-clade (comprising five Southern Hemisphere species of Cominella and Pareuthria); and 2) Retimohnia-clade (uniting three species of the deep-water, temperate North-Pacific genera Retimohnia and Fusipagoda).

The phylogenetic position of particular taxa was checked in the extended coxl tree (Fig. S1, specimens sequenced only for coxl gene are highlighted in red), but these are unfortunately missing in the multigene datasets. Tudicla spirillus, Africofusus africanus and Afer cumingi clustered with Euthria cornea and Euthria japonica in the Buccinulum-clade, with a moderate support ( $\mathrm{B}=78)$ for the grouping of Tudicla-Euthria-Africofusus. The two sequenced specimens of Aulacofusus periscelidus formed a group sister to the Neptunea-clade in the $\mathrm{Bu}$-grouping, although with weak support $(\mathrm{B}=73)$. The sequenced specimen of Ancistrolepis grammatus formed a well-supported clade with Clinopegma magnum ( $\mathrm{B}=99$ ), Parancistrolepis fujitai is clastering with high support $(\mathrm{B}=100)$ with Thalassoplanes moerchi and Pseudoliomesus canaliculatus with Japelion hirasei $(\mathrm{B}=97)$ all in the Bathyancistrolepis-clade. Metajapelion pericochlion is clustering with high support with Metajapelion adelphicus $(\mathrm{B}=100)$. Plicifusus rhyssus is clustering with Anomalisipho verkruezeni and "Colus" kujianus $(\mathrm{B}=100)$. Four sequenced specimens of Pisania striata fell in the Pisania-clade, although not forming any supported grouping within it. The phylogenetic position of Japeuthria ferrea for which the sequences of coxl, 16S, and $\mathrm{H} 3$ (although, obtained from different individuals) were available from the GenBank was checked by adding these sequences to our Buc5G dataset. The species forms the first offshoot of Siphonalia-clade with the maximal support (Fig. S2).

\section{DISCUSSION}

\section{IMPLICATIONS OF THE PHYLOGENETIC ANALYSIS FOR THE TAXONOMY OF BUCCINOIDEA}

At this stage, pending the results of the analysis of a dataset with broader neogastropod taxon sampling and with broader genome sampling, we cannot confirm the monophyly of the superfamily Buccinoidea, which is not supported in the ML analysis. Thus, for convenience, we accept the usage of the name Buccinoidea for the currently accepted extension of this superfamily. Of the molecular clades resulting from the phylogenetic analysis, seven (Belomitraclade, Buccinum-clade, Colubraria-clade, Columbella-clade, Fasciolaria-clade, Melongenaclade, and Pisania-clade) can be allocated to accepted families (Bouchet et al., 2017), and the status and naming of the remaining ones is addressed in the present section.

The Belomitra-clade corresponds to the monotypic family Belomitridae in its current scope. Based on the supported affinity of the Belomitra- (and Dolicholatirus-) clades and their similar radulae, a possible option could be to expand Belomitridae to include Dolicholatirus and 
1 allied genera in their own belomitrid subfamily. However, as members of Dolicholatirus and

Crassicantharus show absolutely no conchological resemblance to species of Belomitra, we retain Belomitridae in its current scope, and establish a new family Dolicholatiridae for Dolicholatirus and allied genera, as defined by the contents of our Dolicholatirus-clade and the analysis of Couto et al. (2016).

The Colubraria-clade comprises the type species of Colubraria, C. muricata, as well as members of four other colubrariid genera, and therefore corresponds to the Colubrariidae, now globally accepted at the rank of family. The Colus- and Eosipho-clades of the CCBA grouping exclusively comprise taxa that are currently placed in Buccinidae, while being clearly not related to the Buccinum-clade (the latter recovered in the core Buccinoidea grouping, see below). Taking into account the family rank of the Colubraria-clade, we treat the Colus-and Eosipho-clades at the same rank. Because of differences in ecology (representatives of Eosipho-clade live in hydrothermal vents, methane seeps and sunken-wood habitats, while representatives of the Colus-clade dwell in ambient subtidal and bathyal benthic communities), distribution (only boreal and Arctic waters for Colus-clade, versus broad tropical and subtropical distribution for the Eosipho-clade), and morphology (radula) we cannot unite these two clades in a single family. The name Colusinae was established for Colus and some other genera and (despite nomenclatural problems discussed in the Taxonomy section) is herein applied at the rank of family to the Colus-clade. The Eosipho-clade was dealt with by Kantor et al. (2013), but no available name exists for it and we therefore here propose for it a new family Eosiphonidae fam. nov. For the Prosipho-clade, the name Prosiphoninae, established at the rank of subfamily and currently (Bouchet et al., 2017) accepted as a tribe within Buccinidae, is raised to family rank as Prosiphonidae.

The placement of the Buccinum-clade naturally defines the application of the name Buccinidae. Our analysis suggests that the family in its traditional scope is paraphyletic and several of its traditional constituent taxa are here split from it at family rank. Nevertheless, we demonstrate that four phylogenetic lineages (plus the genus Anomalisipho), namely the Neptunea-clade, Beringius-clade, Volutopsius-clade, and Bathyancistrolepis-clade (the latter, based on cox 1, also comprising the genus Ancistrolepis, Parancistrolepis and Pseudoliomesus), are closely related to the Buccinum-clade. These five clades, together forming the well-supported $\mathrm{Bu}$-grouping, correspond to the five subfamilies traditionally recognized within the Buccinidae: Buccininae, Neptuneinae, Beringiinae, Volutopsiinae and Parancistrolepidinae (= Ancistrolepidinae). The Siphonalia-clade is recovered as the sister group to the $\mathrm{Bu}$-grouping in our multigene analyses, also with consistently high support. Siphonalia is the type genus of the subfamily Siphonaliinae and this name can naturally be applied to this clade. The taxonomic extension of the family Buccinidae can be restricted to the boundaries of the $\mathrm{Bu}$-grouping, leading to a family Buccinidae with five subfamilies and a subfamily Siphonaliinae, or alternatively it can be defined to include the Bu-grouping plus the Siphonalia-clade, leading to a single family Buccinidae. Here we favor the second option and include the Siphonalia-clade as a sixth subfamily. The rationale for this decision is that representatives of the Siphonalia-clade are rather heterogeneous morphologically and lack any morphological and anatomical characters that would allow them to be unambigiously distinguished from the $\mathrm{Bu}$-grouping, itself highly morphologically heterogeneous.

All the members of the family Fasciolariidae included in our analysis, except the Dolicholatirus-clade, have clustered in the Fa-grouping. Therefore, we recognize the Fa- 
grouping as the family Fasciolariidae. Branching within the Fa-grouping is consistent with the division into three subfamilies, as was previously concluded by Couto et al. (2016).

Within the BB-grouping, the family group name Busyconidae - currently accepted either as a subfamily of Buccinidae (e.g. MolluscaBase, 2020) or a separate family (e.g. Petuch et al., 2015) - is available for the Busycon-clade. Based on the demonstrated lack of immediate relationship to the Buccinidae as circumscribed herein, we confirm the rank of the Busycon-clade as the family Busyconidae. Buccinanops was traditionally classified in the Nassariidae, where the subfamily Buccinanopsinae was established by Galindo et al. (2016), reflecting the isolated position of Buccinanops in their phylogenetic reconstructions. However, our results show that Buccinanops is not related to the Nassariidae, and it also differs notably in conchological and radula characters from members of the phylogenetically close Busycon-clade. Therefore, we rank the Buccinanops-clade as a separate family Buccinanopsidae. Macron lividus is the closest relative of the Buccinanops clade, and its placement is addressed below in the taxonomic section.

The name Cominellinae (originally a subfamily within Buccinidae) is naturally available for the Cominella-clade. As the Cominella-clade showed no affinity to the Buccinidae, and is not included in any larger, supported cluster within the core Buccinoidea, we raise it to family rank as Cominellidae. Members of the Cominella-clade and the Retimohnia-clade are morphologically highly dissimilar, and there is no family-group name available for the latter. Therefore, we introduce a new family Retimohniidae for the genera Retimohnia and Fusipagoda.

Australian and New Zealand species as well as north Pacific Kelletia spp. from the highly supported PB grouping were recently analysed by Vaux et al. (2017), who generated for these taxa most of the DNA sequences that are included in our analysis. Although they used rather few buccinoidean outgroups in their analysis, Vaux et al. identified a close affinity of the genera Penion, Kelletia, Buccinulum, Aeneator and Antarctoneptunea, and concluded that their placement in a single subfamily (Buccinulinae) is reasonable. Our analysis, however, reveals that the relationships of these genera are more complex, mainly because the genera Aeneator and Buccinulum are actually closer (in the multigene dataset) to the cosmopolitan genus Euthria and (in the expanded coxl dataset) to the tropical Indo-Pacific genera Afer and Tudicla, than to Penion, Kelletia and Antarctoneptunea. The members of the Buccinulum-clade share a synapomorphic feature in radular morphology: a distinct narrowing of the anterior edge of the central tooth, giving it a trapezoid, or sometimes nearly triangular, shape (see Fig. 18G-P). Such tooth shape has not been observed in species of the Penion-clade, nor in any other clades of the Buccinoidea. In light of these new results, we conclude that the two clades should be classified as two separate families. The family name Austrosiphonidae was proposed based on the fossil genus Austrosipho, currently considered a synonym of Penion. We apply it herein to the Penionclade. Based on our results, the name Tudiclidae applies to the Buccinulum-clade, and has a priority over the junior (although widely used) name Buccinulidae. Thus, we here ascribe the name Tudiclidae to the Buccinulum-clade.

The Melongena-clade comprises species representing three genera currently included in the family Melongenidae, among them Melongena melongena, the type species of Melongena. Therefore, we identify this clade as the family Melongenidae. The genera currently included in Pisaniidae fall in two separate clades: the Pisania-clade and the Prodotia-clade (Fig. 1), and the tree suggests the polyphyly of the family as currently defined. All three species of the genus Pisania included in our multigene analyses were recovered in the former clade, as well as Pisania striatula (the type of the genus), included in our expanded coxl dataset. Although the 
analyzed species of Pisania do not form a monophyletic cluster and suggest the polyphyly of the genus, the position of $P$. striatula allows us to unequivocally apply the name Pisaniidae to the Pisania-clade. In most of our reconstructions, the Chauvetia-clade forms a sister group to the Pisaniidae, and species of Chauvetia possess a clearly divergent radula, with a unicuspid or acuspate central tooth and with the bases of the laterals extending to form a 'handle' (see Fig. 20B), very unlike the radulae in the Pisaniidae examined (see Fig. 22). Despite several familygroup names have been proposed for Chauvetia, none of them is nomenclaturally available (Gofas \& Oliver, 2010) and the new family Chauvetiidae is established herein for the Chauvetiaclade. As there is no family-group name available for the Prodotia-clade, we also introduce a new family Prodotiidae for it.

The application of names to the clades resulting from our phylogenetic analysis is most difficult in the $\mathrm{NaCo}$-grouping, mainly because the distinctive families Nassariidae and Columbellidae are not resolved as reciprocally monophyletic clades. All analyzed members of the family Columbellidae cluster in a monophyletic Columbella-clade, with the name Columbellidae readily applicable to it. This clade occupies the most derived position in the $\mathrm{NaCo}$-grouping, making the traditionally accepted Nassariidae (sensu Galindo et al., 2016) paraphyletic. The Phos-clade, representing the subfamily Photinae, branches off first. The next offshoot is the large nassariid cluster combining the Bullia-clade (consistent with the subfamily Bullinae), the Anentome-clade (consistent with the subfamily Anentominae), the Nassariusclade, and three species related to it. The latter can either be entirely attributed to the subfamily Nassariinae, or subdivided into Nassariinae and Dorsaninae. The third offshoot is a distinctive clade combining species of the genera Tomlinia and Nassaria; no family-group name exists for this clade. Finally, the Cyllene-clade (consistent with the nassariid subfamily Cylleninae) forms a sister group to the Columbella-clade. Thus, the topology of our tree supports six or seven distinctive phylogenetic clusters within what is now treated as Nassariidae, and these clusters generally align with the currently recognized subfamilies. The lack of nodal support and morphological criteria does not justify raising the nassariid subfamilies to full families. Additionally, the close relationship between Columbellidae and Nassariidae was not recovered in previous molecular phylogenies. In the reconstructions of Galindo et al. (2016), the Columbellidae form one of the early offshoots of Buccinoidea with moderately high PP support (0.94), while in the phylogenetic reconstruction of Strong and DeMaintenon (in preparation, personal communication) the Columbellidae form a sister group to the Fasciolariidae. This diverging hypotheses cannot presently be resolved and, in order to minimize premature taxonomic changes, we do not make revisions to the contents of the Nassariidae other than the exclusion of Buccinanopsinae. The position of Columbellidae within Buccinoidea remains uncertain, and deserves further studies with broader genomic sampling.

Our analysis provides a phylogenetic framework which allows to test the validity of the morphology-based family group taxa previously proposed in Buccinoidea. The latest classification of the superfamily (Bouchet et al., 2017) recognized eight families and 18 subfamilies (including four nominotypical ones). Most of the family-group taxa recognized in that work were here proven valid, although their composition has in many cases been changed. The present phylogeny-based classification recognizes 20 family level taxa and 22 subfamilies (including five nominotypical ones). Several taxa previously treated in Bouchet et al. (2017) as subfamilies or tribes are now raised to full families (Table 1): Colidae Gray, 1857, Prosiphonidae Powell, 1951, Cominellidae Gray, 1857, Tudiclidae Cossman, 1901, Buccinanopsidae Galindo, 
1 Puillandre, Lozouet \& Bouchet, 2016, and Austrosiphonidae Cotton \& Godfrey, 1938.

2 Additionally, previously unrecognized lineages are revealed and are described below as new

3 taxa: Retimohniidae fam. nov., Prodotiidae fam. nov., Eosiphonidae fam. nov., and Tomliniinae

4 subfam. nov. (Nassariidae). We present below a revised classification of the superfamily with the

5 description of new taxa, including the generic composition of every family-group taxon, based

6 on molecular and in some cases morphological evidence. We did not consider in detail the

7 composition and scope of the family Fasciolariidae, because it was the subject of a molecular

8 phylogeny by Couto et al. (2016), and Columbellidae, because it is being separately re-assessed

9 by M. deMaitenon and E. Strong (personal communication).

10

Class Gastropoda CUVIER, 1795

SUBCLASS CAENOGASTROPODA COX, 1960

ORDER NEOGASTROPODA WENZ, 1938

SUPERFAMILY BUCCINOIDEA RAFINESQUE, 1815

FAMILY DOLICHOLATIRIDAE FAM. NOV.

(Figs 3A-E; 4A-C)

Type genus: Dolicholatirus Bellardi, 1884

Included genera:

Crassicantharus Ponder, 1972 (TS Crassicantharus norfolkensis Ponder, 1972; OD) (1)

Dolicholatirus Bellardi, 1884 (TS †Fusus bronnii Michelotti, 1847; SD, Cossmann, 1901) (1)

Teralatirus Coomans, 1965 (TS Latirus ernesti Melvill, 1910 [= Teralatirus roboreus (Reeve, 1845)]; OD) ${ }^{(1)}$

Diagnosis. Shell small to medium large $(60 \mathrm{~mm})$, from broad to narrow fusiform or turriform. Spire tall, siphonal canal from very short to very long, constituting nearly half of SL. Protoconch paucispiral, with smooth initial part and later whorls sometimes bearing axial ribs. Spiral sculpture of fine to strong cords, sometimes pronounced only in interspaces between axial ribs. Axial sculpture of strong, broad axial ribs present in most species. Columella sometimes with two weak columellar plaits. Shell usually of dark colour, sometimes with brightly coloured spiral bands. Operculum with terminal nucleus or paucispiral.

Radula (Fig. 4A-C) with squarish, narrow central tooth with three closely spaced cusps, lateral cusps distinct or nearly obsolete. Lateral teeth long, with base forming about a third of total tooth length, narrowing towards its tip, bearing two cusps, inner one much longer and constituting about a third of total tooth length; sometimes an additional small cusp on the inner internal side of the tooth, close to its base and not seen in dorsal view (Fig. 4B).

Proboscis medium long and very narrow, single or paired ventral proboscis retractor, attached to anterior or medium part of rhynchodaeum. Salivary glands paired, large. Oesophagus very narrow. Valve of Leiblein sphaerical, 6 or 7 times wider than the very narrow oesophagus, gland of Leiblein tubular or bulky, medium to large.

Distribution. From the lower intertidal to lower bathyal depths in the tropical Pacific and Atlantic.

Remarks. The genera included in Dolicholatiridae have traditionally been classified in Fasciolariidae, but Ponder (1972) already noticed the uniqueness of the radula and protoconch morphology of Crassicantharus. That genus was later referred to the Buccinoidea without 
definite family allocation (Fraussen \& Stahlschmidt, 2015), and Dolicholatirus was also at some point tentatively attributed to the Turbinellidae (Vermeij \& Snyder, 2006: 414). Based on a multilocus molecular phylogeny, Couto et al. (2016) demonstrated that seven species in the genera Dolicholatirus and Teralatirus formed a clade unrelated to the rest of the Fasciolariidae, but no formal taxonomic conclusion was then made.

The radular morphology of Dolicholatiridae is very characteristic and bears some resemblance to the Belomitridae, their sister taxon in our phylogeny, in having long and narrow lateral teeth with cusps closer to the tip (Fig. 4).

The genera here included in the family need taxonomic revision, since Dolicholatirus was not recovered monophyletic, while Crassicantharus noumeensis (Crosse, 1870), sometimes referred to Teralatirus, did not cluster with T. roboreus, the type species of Teralatirus, in the molecular tree of Couto et al. (2016).

The anatomy of Teralatirus roboreus was examined by Simone et al. (2013), and of Dolicholatirus lancea and Crassicantharus noumeensis by ourselves (original unpublished data). Simone et al. (2013: 222) remarked the presence of an enigmatic "oesophageal gland", not separated from the posterior oesophagus, and the absence of the gland of Leiblein. In Dolicholatirus and Crassicantharus, there is a distinct gland of Leiblein that runs dorsally along the oesophagus, and is similar to the "oesophageal gland" reported by Simone et al. (2013).

\title{
FAMILY BELOMITRIDAE KANTOR, PUILLANDRE, RIVASSEAU \& BOUCHET, 2012
} (Figs 3F, G, 4D-F)

\author{
Type genus: Belomitra P. Fischer, 1883
}

Included genera:

Belomitra P. Fischer, 1883 (TS Belomitra paradoxa P. Fischer, 1883; M) ${ }^{(1)}$ (see Kantor et al., 2012 for synonymy)

Diagnosis. Shell small $(7 \mathrm{~mm})$ to medium large (over $50 \mathrm{~mm}$ ), turriform, with high spire and short siphonal canal. Protoconch paucispiral, white. Subsutural ramp usually well pronounced, followed by distinct shoulder. Shell sculpture consisting of axial ribs present at least on spire whorls, and spiral cords, sometimes forming knobs at intersections with axial ribs. Columella sometimes with weak plaits. Shell colour white or pale olive-grey, sometimes with thick olivaceous periostracum. Operculum present or absent, when present with terminal nucleus.

Radula (Fig. 4D-F) with central tooth with rectangular or trapeziform base and 3-8 cusps; lateral teeth with very long narrow base and two small cusps closer to tip. Proboscis mediumlong to long, proboscis retractors multiple, attached laterally to central portion of rhynchodaeum. Paired large salivary glands, salivary ducts follow inside oesophagus walls. Gland of Leiblein very large, valve of Leiblein well defined. Stomach without posterior mixing area. (Anatomy description based on several species studied by Kantor et al., 2012).

Distribution. Temperate to tropical Atlantic, entire Pacific and Indian oceans at bathyal depths.

Remarks. The relationships of Belomitridae to other Buccinoidea were previously uncertain due to the very limited dataset used in the original molecular phylogenetic analysis (Kantor et al., 2012). The present analysis shows a highly supported relationship with the family 
1 Dolicholatiridae fam. nov., from which the Belomitridae differ in having a relatively larger

2
FAMILY COLUBRARIIDAE DALL, 1904

(Figs 5A-E, 6A-C)

Type genus: Colubraria Schumacher, 1817

= Fusidae Iredale, 1915. Type genus: Fusus Helbling, 1779. Invalid name: type genus placed on the Official Index by ICZN Opinion 1765 (1994).

= Kanamaruidae Higo \& Goto, 1993. Type genus: Kanamarua Kuroda, 1951.

Included genera:

Axifex S.-I Huang \& M.-H. Lin, 2019 (TS Axifex retis S.-I Huang \& M.-H. Lin, 2019; OD) ${ }^{(3)}$

Bartschia Rehder, 1943 (TS Bartschia significans Rehder, 1943; OD) ${ }^{(3)}$

Colubraria Schumacher, 1817 (TS Colubraria granulata Schumacher, 1817 [= Colubraria muricata ([Lightfoot], 1786)]; M) ${ }^{(1)}$

Cumia Bivona-Bernardi, 1838 (TS Cumia decussata Bivona-Bernardi, 1838 [= Cumia reticulata (Blainville, 1829)]; M). Synonym: Fusus Helbling, 1779 (TS Murex intertextus Helbling, 1779; SD, Dall, 1906). Invalid: type genus placed on the Official Index by ICZN Opinion 1765 (1994). ${ }^{(1)}$

Cyclimetula S.-I Huang \& M.-H. Lin, 2019 (TS Cyclimetula hsui S.-I Huang \& M.-H. Lin, 2019; OD) ${ }^{(3)}$

Iredalula Finlay, 1926 (TS $†$ Bela striata Hutton, 1873; OD) ${ }^{(3)}$

Kanamarua Kuroda, 1951 (TS Colus adonis Dall, 1919; OD) ${ }^{(1)}$

Metula H. Adams \& A. Adams, 1853 (TS Buccinum clathratum A. Adams \& Reeve, 1850 [= Metula knudseni Kilburn, 1975]; SD, Kobelt, 1876) ${ }^{(1)}$

Minibraria Sarasúa, 1984 (TS Colubraria monroei McGinty, 1962; OD) ${ }^{(3)}$

Diagnosis. Shell medium large to large, reaching over $110 \mathrm{~mm}$, from narrow fusiform to broad fusiform, with medium to high spire and short but distinct siphonal canal. Protoconch usually paucispiral of 1-2.5 smooth whorls, up to 4 whorls (Metula). Spire whorls evenly convex, without pronounced shoulder. Axial sculpture present or absent, when present of distinct narrow and closely spaced axial ribs, crossing the spiral cords and forming reticulated sculpture pattern, often with regularly or irregularly spaced varices. Spiral sculpture of very weak threads, or fine, regularly set, beaded cords, or strong spiral cords forming knobs at intersection with axials. Aperture medium to high, lanceolate due to sharp posterior corner. Outer lip usually lirate inside, smooth in some species of Kanamarua. Columella smooth, often heavily callused. Operculum oval, spanning about half aperture, with terminal nucleus shifted leftwards.

Radula very small, variable in teeth morphology. In Colubraria central tooth broadly arcuate, with about 10 , subequal, relatively long cusps; lateral teeth very broad, with 10 or 11 subequal cusps, gradually diminishing towards inner side (Fig. 6A). In Cumia, Iredalula and Metula, teeth more narrow, central with 3-7 relatively short and broadly spaced cusps; laterals with 3 or 4 cusps (Fig. 6B, C). Proboscis extremely long and narrow, multiple coiled within rhynchocoel. Proboscis retractors paired, attached to the base or middle part of rhynchodaeum. 
Valve of Leiblein either absent or poorly defined, gland of Leiblein absent, salivary glands medium-sized, not fused, ducts entering oesophagus wall soon after leaving glands, and following within it. Middle oesophagus very narrow when passing through nerve ring, posterior oesophagus greatly expanded, muscular. Stomach large, sac-like, thin-walled, straight, tapering posteriorly towards the very narrow intestine.

Distribution. Temperate to tropical Indo-Pacific and Atlantic, from subtidal to several hundred meters.

Remarks. The anatomy of several species was examined by Ponder (1968) and Oliverio \& Modica (2010). At least Colubraria and Cumia are haematophagous, feeding on the blood of sleeping parrot fishes (Scaridae) and occasionally of other fishes (Bouchet \& Perrine 1996; Oliverio \& Modica, 2010). The very similar anatomy of Metula suggests similar feeding habits, but these have not been observed.

FAMILY COLIDAE GRAY, 1857 (new rank)

(Figs 5F-L, 6D)

Type genus: Colus Röding, 1798

Included genera:

Colus Röding, 1798 (TS Murex islandicus Mohr, 1786; SD, Dall, 1906) (1)

Turrisipho Dautzenberg \& H. Fischer, 1912 (TS Fusus lachesis Mörch, 1869; OD) (1)

Diagnosis. Shell thin-walled, medium-large to large, reaching $200 \mathrm{~mm}$, fusiform to broad fusiform or ovate, with moderately high to very high spire and distinct, slender, moderately long to long siphonal canal. Protoconch either medium-large, paucispiral of up to 2.5 smooth whorls (Colus) or with small smooth nucleus and remaining whorls with distinct spiral keels and unclear protoconch / teleoconch transition (Turrisipho). Shoulder not pronounced, whorls evenly (sometimes strongly) convex, or with flattened abapical portion and whorl periphery. Axial sculpture absent, spiral sculpture of cords of varying strength and width, from very weak to distinct and evenly spaced. Aperture moderately high to high, broadly ovate; outer lip simple. Shell covered with brown periostracum, siphonal canal and inside of aperture off-white. Operculum large, ovate to triangular, with terminal nucleus shifted adaxially, in Turrisipho nucleus drawn out into a small apical point.

Central tooth with rectangular or nearly square bases arcuated anteriorly, bearing 1-3 closely spaced cusps, central one largest. Lateral teeth typically with 3 cusps, outermost much longer than others, middle one smallest (Fig. 6D). Proboscis long, straight. Proboscis retractors numerous, arranged in bundles attached to lateral sides of rhynchodaeum. Salivary glands moderately large, not fused. Gland of Leiblein moderately large, broad, tubular and folded anteriorly, valve of Leiblein poorly defined. Stomach with short posterior mixing area.

Distribution. Northern Atlantic and Arctic Oceans, from subtidal to bathyal depths.

Remarks. The use of the name Colidae for this clade is fraught with nomenclatural difficulty. The concept of the genus name Colus has differed significantly in the publications of various authors, due to the late fixation of the type species by Dall (1906). When he established the name Colus, Röding (1798) included in it species that are presently attributed to several families, including Fasciolariidae (e.g. Murex tulipa Linnaeus, 1758 [now Fasciolaria tulipa]) and Buccinidae (Murex islandicus Mohr, 1786). When he established the subfamily Colinae of 
the family Muricidae, Gray (1857: 12, as Colusina) also treated Colus as a genus mostly including species of present day Fasciolariidae, but also a species of Austrosiphonidae (Fusus dilatatus Quoy \& Gaimard, 1833 [=Penion sulcatus (Lamarck, 1816)]). Nevertheless he also included in the subfamily the genera Chrysodomus Swainson, 1840 (=Neptunea Röding, 1798) and Strombella Gray, 1857 (= Volutopsius Mörch, 1857); Murex islandicus Mohr, 1786, that later (Dall 1906) would fix as the type species of Colus, was attributed to Chrysodomus. Cotton \& Godfrey (1932) used the family name Colidae in the sense of a fasciolariid. Ponder \& Warén (1988) treated Colinae as a synonym of Buccinidae, not Fasciolariidae, while Bouchet \& Rocroi (2005) and Bouchet et al. (2017) used it for a tribe (Colini) of Buccinidae, as a senior synonym of Neptuneinae Stimpson, 1865; the name Colinae was repeatedly used since 2005 by Kosyan and co-authors (e.g. Kosyan, 2006; Kosyan \& Kantor, 2013, 2014; 2015, 2016). This is a situation covered by Art. 65.2 of the ICZN, and the case is to be referred to the Commission for a ruling. Despite this nomenclatural problem, we prefer to use at present the name Colidae in the sense already accepted by Bouchet \& Rocroi (2005) and Bouchet et al. (2017) and later authors, with the authorship of Gray (1857), pending an application to the Commission.

At this moment, we only attribute two genera to Colidae, both based on molecular data. The shell, body morphology and radula of Colidae do not display any unique characters and hardly offer reliable proxies for family recognition. There are a number of genera that can possibly belong to Colidae, among them Helicofusus Dall, 1916, Kryptos Dautzenberg \& H. Fischer, 1896, which have a radula similar to those of Colus species, but similar radulae are also found in Buccinidae s.s. (e.g., Aulacofusus Dall, 1918). For now we refrain from placing them in Colidae pending further molecular data.

\section{FAMILY EOSIPHONIDAE FAM. NOV.}

(Figs 6E-L, 7)

Type genus: Eosipho Thiele, 1929

Included genera:

Americominella Klappenbach \& Ureta, 1972 (TS Americominella duartei Klappenbach \& Ureta, 1972; OD) (2) — radula, see Penchaszadeh et al. (2019)

Calagrassor Kantor, Puillandre, Fraussen, Fedosov \& Bouchet, 2013 (TS Cantharus aldermenensis Powell, 1971; OD) ${ }^{(1)}$

Eclectofusus Fraussen \& Stahlschmidt, 2013 (TS Pararetifusus dedonderi Fraussen \& Hadorn, 2001; OD) ${ }^{(1)}$

Enigmaticolus Fraussen, 2008 (TS Enigmaticolus monnieri Fraussen, 2008 [= E. nipponensis (Okutani \& Fujiwara, 2000)]; OD) ${ }^{(1)}$

Eosipho Thiele, 1929 (TS Chrysodomus smithi Schepman, 1911; OD) ${ }^{(1)}$

Gaillea Kantor, Puillandre, Fraussen, Fedosov \& Bouchet, 2013 (TS Eosipho coriolis Bouchet \& Warén, 1986; OD) ${ }^{(1)}$

Manaria E.A. Smith, 1906 (TS Manaria thurstoni E.A. Smith, 1906; M) ${ }^{(1)}$

Preangeria K. Martin, 1921 (TS † Preangeria angsanana K. Martin, 1921; OD) ${ }^{(2)}$ — radula, see Bouchet \& Warén (1986: Preangeria dentata (Schepman, 1911), as Eosipho dentatus) 


\section{Thermosipho Kantor, Puillandre, Fraussen, Fedosov \& Bouchet, 2013 (TS Eosipho auzendei} Warén \& Bouchet, 2001; OD) ${ }^{(1)}$

Warenius Kantor, Kosyan, Sorokin, Herbert \& Fedosov, 2020 (TS Costaria crosnieri Bouchet \& Warén, 1986; OD) ${ }^{(1)}$

Diagnosis. Shell medium-sized to large, from slightly over $10 \mathrm{~mm}$ to $100 \mathrm{~mm}$, from ovate to narrowly fusiform. Siphonal canal from nearly absent (Thermosipho) to long (Manaria). Protoconch small, often eroded, paucispiral when known, with less than 2 whorls. Spire whorls usually evenly convex, rarely shouldered mainly due to axial sculpture. Axial sculpture either absent (Thermosipho, "Aulacofusus" hiranoi) or represented by very weak to strong ribs or wide, rounded folds. Spiral sculpture (except Thermosipho with smooth shell) of distinct cords of uneven strength, breadth and density. In Eclectofusus sculpture forms a reticulated pattern due to the intersection of narrow axial ribs and broadly spaced spiral cords. Aperture ovate or elongate, with smooth inner and outer lip, or a bearing labral tooth (Preangeria). Shell covered with periostracum, from smooth to hirsute, or forming spines (Americominella). Operculum leaf shaped, with terminal nucleus.

Radula variable (Fig. 6E-L). In most genera lateral teeth with two large cusps, subequal or outer one longer. Central with three large cusps and subrectangular base notched anteriorly (Fig. 6E-G). In Eclectofusus lateral teeth have three cusps, central shortest (Fig. 6H, I). In Warenius radula very different, with lateral teeth with three cusps with bifurcating outer one. Central tooth narrow and long, constricted anteriorly and broadened posteriorly with posterior margin bearing three cusps, central one shortest (Fig. 6K).

Proboscis long to very long and coiled within rhynchocoel. Salivary glands medium large, fused. Posterior oesophagus with distinct caecum. Gland of Leiblein large, bulky, broadly tubular and folded anteriorly, valve of Leiblein prominent. Stomach U-shaped with hardly discernible posterior mixing area.

Distribution. Tropical and temperate south-western Atlantic, Western and Central IndoPacific, and temperate northern Pacific from upper subtidal to lower bathyal depths.

Remarks. This clade combining several genera from different biogenic substrates was first discovered and characterized by Kantor et al. (2013) and is herein expanded to include several additional genera (Eclectofusus, Americominella, Preangeria and Warenius).

The anatomy of Enigmaticolus and Calagrassor has been described by Kantor et al. (2013).

The first branch of the family to diverge from the others is "Aulacofusus" hiranoi (Shikama, 1962), described as Colus calameus hiranoi and transferred to Aulacofusus by Higo et al. (1999: 229), a transfer later accepted (Hasegawa, 2009; Kosyan \& Kantor, 2013). Hasegawa (2009] mentioned that "juvenile specimens smaller than ca $1.5 \mathrm{~cm}$ SL were found attached to pieces of sunken wood, and a similar ecology has been observed in A. coerulescens (Kuroda \& Habe in Habe, 1961)". Its generic allocation is, however, unconfirmed since it is conchologically somewhat different from other Aulacofusus and the radula and anatomy have not been examined. "A." hiranoi may belong to a new genus (see Discussion section of the subfamily Neptuneinae).

In our analysis, Manaria is found polyphyletic, as Manaria fluentisona Fraussen \& Stahlschmidt, 2016 (Fig. 7F) clusters with species of Eclectofusus. Conchologically, it is particularly similar to E. dedonderi (Fraussen \& Hadorn, 2001) (Fig. 7G) in the reticulated 
sculpture pattern and strong periostracum, and we thus transfer Manaria fluentisona to Eclectofusus.

One specimen (MNHN IM-2013-60365; Fig. 7L) from the upper bathyal of Guadeloupe has a shell similar to Calagrassor, but differs in having a slightly angulated shoulder and a weakly concave subsutural region, which is evenly convex in known species of Callagrassor. It occupies an isolated position in the multigene tree, and probably represents a new species and genus of Eosiphonidae.

The genus Americominella includes two species and is attributed to the family on the basis of radula and, to some extent, shell similarities between the type species, A. duartei, and Eclectofusus dedonderi, as mentioned by Fraussen \& Hadorn (2001).

Representatives of the family are colonizing three major types of biogenic substrates: hydrothermal vents, methane seeps and sunken wood (Kantor et al., 2013). Thermosipho and Enigmaticolus are specialized on vents and seeps. At least one species, Calagrassor aldermenensis is known to inhabit exclusively sunken logs, hiding deep inside holes. Many other species of Calagrassor and Eosipho are often found in hauls containing sunken wood, but not attached to the logs themselves, so we only have indirect evidence of their association with wood. Manaria specimens, together with Calagrassor aldermenensis, were recovered from traps deployed in deep water off Santo, Vanuatu, containing wood and protected by a netting with a 3 $\mathrm{mm}$ mesh, suggesting that the sunken wood is colonized by larvae or very young juveniles. Warenius nankaiensis is associated with seeps (Okutani \& Iwasaki, 2003).

The marked differences in ecology (ambient bottom communities in the former and biogenic substrates in the latter), distribution (northern Atlantic and Arctic Ocean vs tropical and temperate Atlantic and Indo-Pacific) and morphology (radula with tricuspid vs bicuspid lateral teeth; stomach with short posterior mixing area vs U-shaped stomach lacking posterior mixing area) reinforces the phylogeny-derived ranking of Colidae and Eosiphonidae as full families.

\section{FAMILY PROSIPHONIDAE POWELL, 1951 (new rank)}

(Figs 8,9)

Type genus: Prosipho Thiele, 1912

Included genera:

Anomacme Strebel, 1905 (TS Anomacme smithi Strebel, 1905; M) (2); radula, see Powell (1951) Antarctodomus Dell, 1972 (TS Bathydomus thielei Powell, 1958; OD) ${ }^{(1)}$

Antistreptus Dall, 1902 (TS Antistreptus magellanicus Dall, 1902; OD) (2); radula, see Pastorino \& Griffin (2019)

Argeneuthria Pastorino, 2016 (TS Euthria cerealis Rochebrune \& Mabille, 1885; OD) (2); radula, see Pastorino (2016)

Austrofusus Kobelt, 1879 (TS Fusus nodosus Gray, 1843 [= Drupa glans Röding, 1798]; SD, Martens, 1882) (1)

Bathydomus Thiele, 1912 (TS Bathydomus obtectus Thiele, 1912; M) (2); radula, see Thiele (1912)

Cavineptunea Powell, 1951 (TS Cavineptunea monstrosa Powell, 1951; OD) ${ }^{(1)}$

Chlanidota Martens, 1878 (TS Cominella vestita Martens, 1878; M) (1) 
Chlanidotella Thiele, 1929 (TS Cominella modesta Martens, 1885; OD) ${ }^{(2)}$; radula, see Powell (1951)

Chlanificula Powell, 1958 (TS Chlanificula thielei Powell, 1958; OD) (2); radula, see Hain (1990)

Crenatosipho Linse, 2002 (TS Crenatosipho beaglensis Linse, 2002; OD) (2); radula, see Linse (2002)

Drepanodontus Harasewych \& Kantor, 2004 (TS Drepanodontus tatyanae Harasewych \& Kantor, 2004; OD) (2); radula, see Harasewych \& Kantor (2004)

Falsimacme Pastorino, 2016 (TS Euthria kobelti Strebel, 1905; OD) (2); radula, see Pastorino (2016)

Falsimohnia Powell, 1951 (TS Buccinum albozonatum Watson, 1882; OD) (1)

Fusinella Thiele, 1917 (TS Buccinella jucunda Thiele, 1912; by typification of replaced name [Buccinella Thiele, 1912]) ${ }^{(2)}$; radula, see Thiele (1912)

Germonea Harasewych \& Kantor, 2004 (TS Germonea rachelae Harasewych \& Kantor, 2004; OD) ${ }^{(2)}$; radula, see Harasewych \& Kantor (2004)

Meteuthria Thiele, 1912 (TS Euthria martensi Strebel, 1905, M) (2); radula, see Pastorino (2016) Muffinbuccinum Harasewych \& Kantor, 2004 (TS Muffinbuccinum catherinae Harasewych \& Kantor, 2004; OD) ${ }^{(2)}$; radula, see Harasewych \& Kantor (2004)

Neobuccinum E.A. Smith, 1879 (TS Buccinopsis eatoni E.A. Smith, 1875; M) ${ }^{(1)}$

Parabuccinum Harasewych, Kantor \& Linse, 2000 (TS Chlanidota bisculpta Dell, 1990; OD) (2); radula, see Harasewych et al. (2000)

Probuccinum Thiele, 1912 (TS Neobuccinum tenerum E.A. Smith, 1907; SD, Wenz, 1943) (1)

Proneptunea Thiele, 1912 (TS Proneptunea amabilis Thiele, 1912; M) ${ }^{(1)}$

Prosipho Thiele, 1912 (TS Prosipho gaussianus Thiele, 1912; SD, Powell, 1951) (1)

Savatieria Rochebrune \& Mabille, 1885 (TS Savatieria frigida Rochebrune \& Mabille, 1885; M)

(2); radula, see Luca \& Pastorino (2018)

Spikebuccinum Harasewych \& Kantor, 2004 (TS Spikebuccinum stephaniae Harasewych \& Kantor, 2004; OD) ${ }^{(2)}$; radula, see Harasewych \& Kantor (2004)

Strebela Kantor \& Harasewych, 2013 (TS Bela notophila Strebel, 1908; OD) (2); radula, see Kantor \& Harasewych (2013)

Diagnosis. Shell from small (less than $5 \mathrm{~mm}$ ) to medium large (over $60 \mathrm{~mm}$ ), thin-walled, varying from oval without siphonal canal but with siphonal notch, to fusiform with distinct, attenuated canal. Protoconch when present paucispiral (in most cases dissolved), medium large of 1.5-2.5 smooth whorls, or multispiral with a small first whorl, suggesting planktonic development (Austrofusus). Shell usually dextral, sinistral in Antistreptus. Whorl profile typically evenly convex. Spiral sculture usually dominant, represented by cords, from very fine and closely set to strong and raised or wide and flattened. Axial sculpture usually not pronounced, when present represented by weak to strong ribs, sometimes forming nodules at intersection with spiral cords. Aperture wide, with smooth outer lip. Periostracum from thin and smooth to strong, forming axial lamellae. Shell colour white, whitish, pale, or light brown, inside of aperture white. Operculum paucispiral or with terminal nucleus.

Radula is very variable and can be classified in six different types.

1. Lateral teeth with 3-5 cusps, outermost longest, inner one significantly shorter, central tooth with subsquare or subrectangular base and notched anterior edge and 3-5 sharp cusps (Fig. 


\section{A) - found in Neobuccinum, Probuccinum, Chlanidota, Austrofusus, Cavineptunea,} Parabuccinum, Chlanificula, Spikebuccinum, Bathydomus.

2. Lateral teeth bicuspid, with subequal cusps, and outer portion of basal plate attenuated, long. Central tooth with square base and single, large, pointed cusp (Fig. 9B) - found in Falsimohnia, Strebela.

3. Lateral teeth multicuspid, with 4-7 subequal cusps, outermost shortest, sometimes with rows of denticles along the outer edge of outer cusp. Central tooth with subsquare or subrectangular base and notched anterior edge and 3 sharp cusps (Fig. 9C) - found in Proneptunea, Maffinbuccinum, Chlanidotella

4. Prosipho type. Lateral teeth varying in shape, but always with very long and narrow attenuated outer portion of basal plate, forming "handle", and with 2-7 cusps. Central tooth sometimes absent, when present varying from very small, acuspate to well developed, bearing three cusps (Fig. 9 D, F-I). Found in Prosipho, Anomacne, Antistreptus, Argeneuthria, Crenatosipho, Falsimacme, Fusinella, Meteuthria, Savatieria, Germonea.

5. Antarctodomus type. Lateral teeth with narrow base and two long, very closely spaced cusps, outer one slightly longer. Central tooth broad with three blunt cusps (Numanami, 1996: fig. 96D).

6. Drepanodontus type. Lateral teeth with a single large cusp (seems to be homologous to the outermost cusp in other genera) and small 1-3 cusplets on inner side of the cusp (Fig. 9E).

Proboscis usually not long and relatively thick, proboscis retractors either paired and attached laterally in the middle part of rhynchodaeum (Falsimohnia, Parabuccinum), or numerous and arranged in lateral bundles in mid-rhynchodaeum (others). Salivary glands medium-sized to very large, paired, sometimes fused (Germonea). Gland of Leiblein from vestigial (Parabuccinum) to very large (Germonea), valve of Leiblein well defined even when gland of Leiblein vestigial. Stomach either U-shaped, or broad U-shaped, without defined posterior mixing area.

Distribution. Antarctic and subantarctic waters, Magellan Province, from subtidal to abyssal depths.

Remarks. The concept and scope of this family is radically changed by the present study. Powell (1951) established the name Prosiphiinae without providing any diagnosis or statement about the erection of this new family group name. It was rather vaguely circumscribed as a subfamily of Buccinulidae, to include several Antarctic and Magellanic genera (Meteuthria, Prosipho, Anomacme, Fusinella, Proneptunea and Chlanidotella) with "central tooth tricuspid, lateral teeth multicuspid"; Powell (1951: 132) added that "typically, the laterals have a long basal projection, like a handle". Other Antarctic and subantarctic buccinoid genera were attributed by Powell to the Buccinulidae subfamilies Buccinulinae (central and lateral teeth tricuspid) and Cominellinae (central tooth tricuspid, lateral teeth bicuspid). Powell himself considered this classification provisional, having characterized it as "probably more convenient than real".

Our phylogeny demonstrates that the genera that Powell included in Buccinulinae (Chlanidota, Neobuccinum, Probuccinum, Cavineptunea, and Bathydomus) and Cominellinae (Falsimohnia) are actually closely related to Prosipho, in spite of notable differences in radular morphology. Beside Antarctic and subantarctic species, Prosiphonidae includes species from New Zealand (Austrofusus glans) and Tasmania (Antarctodomus cf. powelli). It should be emphasized that practically no Magellanic genera were available for inclusion in the molecular 
analysis and these are attributed to Prosiphonidae based on radula similarities with sequenced species, but it cannot be excluded that they constitute independent phylogenetic lineages.

The anatomy was studied in the sequenced genera Chlanidota (Harasewych \& Kantor, 1999) and Falsimohnia (Kantor \& Harasewych, 2013), as well as in the non-sequenced genera Drepanodontus, Germonea, Muffinbuccinum, Spikebuccinum (Kantor \& Harasewych, 2013) and Parabuccinum (Harasewych et al., 2000), and our family diagnosis is based on these studies.

\section{FAMILY BUCCINIDAE RAFINESQUE, 1815}

(Figs 10-14)

Type genus: Buccinum Linnaeus, 1758

\section{SUBFAMILY BUCCININAE RAFINESQUE, 1815}

(Fig. 10A-F)

Included genera:

Buccinum Linnaeus, 1758 (TS Buccinum undatum Linnaeus, 1758; SD, Montfort, 1810) ${ }^{(1)}$. Synonyms: Volutharpa P. Fischer, 1856 (TS Volutharpa deshayesiana P. Fischer, 1856; M; syn. nov.); Bathybuccinum Golikov \& Sirenko, 1989 (TS Bathybuccinum bicordatum Golikov \& Sirenko, 1989; OD; syn. nov.)

Ovulatibuccinum Golikov \& Sirenko, 1989 (TS Buccinum ovulum Dall, 1895; OD) (1)

Thysanobuccinum Golikov \& Gulbin, 1980 (TS Buccinum tunicatum Golikov \& Gulbin, 1977; OD) (1)

Diagnosis. Shell from small to large (over $150 \mathrm{~mm}$ ), oval to broadly fusiform, without siphonal canal and with siphonal notch. Protoconch paucispiral. Whorls convex to (sub)cylindrical, shouldered, sometimes with strong keel at shoulder. Shell sculpture pronounced in most cases, spiral sculpture from microscopic threads to prominent keels; axial sculpture, when present, of distinct, broad, sigmoid or arcuated axial ribs. Shell covered with ciliated periostracum, sometimes very thick and forming lamellae. Aperture wide, ovate with simple outer lip. Operculum small to large, with subcentral nucleus.

Radula with central tooth with broad rectangular base, notched anteriorly, and with nearly straight posterior margin with 4-8 cusps; lateral teeth with 3-4 cusps, intermediate one much shorter than outer and inner ones. Proboscis long, proboscis retractors multiple, attached laterally to posterior portion of rhynchodaeum. Paired small salivary glands. Gland of Leiblein small, tubular, valve of Leiblein small. Stomach with long posterior mixing area (Kantor, 2003).

Individual hemispherical egg capsules forming large ball-shaped clusters. Direct development with nurse eggs and adelphophagy (Fretter \& Graham, 1962).

Distribution. Temperate northern Atlantic and temperate northern Pacific to Arctic, from intertidal to abyssal depths.

Remarks. The molecular phylogenetic analysis did not resolve Volutharpa and Bathybuccinum as separate genera and they are accepted as synonyms of Buccinum (for clarity we use the name of the synonyms on the tree, Fig. 2). The status of Plicibuccinum Golikov \& Gulbin, 1977 (TS Plicibuccinum plicatum Golikov \& Gulbin, 1977 [= Buccinum ochotense 
declivis Habe \& Ito, 1976]; OD) and Corneobuccinum Golikov \& Gulbin, 1977 (TS Colus (Latisipho) lepidus Dall, 1918; OD) remains uncertain.

\section{SUBFAMILY BERINGIINAE GOLIKOV \& STAROBOGATOV, 1975}

(Figs 10G-K, 11C)

Type genus: Beringius Dall, 1887

= Metajapelioninae Goryachev, 1987 (as subfamily of Beringiidae). Type genus: Metajapelion Goryachev, 1987.

Included genera:

Beringius Dall, 1887 (TS Chrysodomus crebricostatus Dall, 1877; M) ${ }^{(1)}$

Metajapelion Goryachev, 1987 (TS Tritonium pericochlion Schrenck, 1862; OD) (1)

Neoberingius Habe \& Ito, 1965 (TS Beringius frielei Dall, 1895, OD) ${ }^{(2)}$; radula, see Habe \& Sato (1973)

Diagnosis. Shell large, reaching $140 \mathrm{~mm}$, broadly fusiform, with high spire and very short to obsolete siphonal canal. Protoconch paucispiral, of about 2-2.5 whorls, very large, diameter similar to, or even exceeding, that of first teleoconch whorls. Whorl profile subcylindrical to evenly convex. Shell sculpture pronounced in most cases, spiral sculpture from microscopic threads to prominent keels; axial sculpture, when present, of distinct, broad, arcuated axial ribs. Aperture wide, ovate. Shell pale or brownish, covered with smooth periostracum. Operculum very large, may exceed aperture length, detached from foot on large, oldest portion, with terminal nucleus.

Radula (Fig. 11C) with cuspless, subrectangular, plate-like central tooth; lateral teeth long, with narrow base of about $1 / 3$ of tooth height, with 3 , rarely 4 , cusps, outermost one much longer. Proboscis long, thick, proboscis retractors multiple, attaching laterally to posterior portion of rhynchodaeum. Paired, medium-sized, salivary glands. Salivary ducts very thick. Gland of Leiblein small, tubular, valve of Leiblein rounded, medium-sized.

Individual egg capsules very large, rounded, with one convex and another concave surface, reaching more than $50 \mathrm{~mm}$, with stalk, attached to substrate. Capsules aggregate in linear clusters. Capsule wall multilayered. Development direct, with nurse eggs, emerging molluscs very large, reaching more than $15 \mathrm{~mm}$ in SL (Gulbin, 2018).

Distribution. Temperate northern Atlantic and temperate northern Pacific to Arctic, from subtidal to lower bathyal depths.

Remarks. In addition to three species of Beringius, "Japelion" adelphicus (Dall, 1907) and "Berinigus" aleuticus Dall, 1895 are clustering together in our multigene analysis. "Japelion" adelphicus has a radula (Fig. 11C) morphologically similar to Beringius spp. (Bouchet \& Warén, 1985: fig. 467, sic!; Habe \& Sato, 1973: fig. 13). The radula of " $B$. ." aleuticus is unknown. "Beringius" aleuticus is different in shell shape from other species of Beringius, particularly in having an ovoid, non-sculptured shell with very short canal. The isolated position of this species in our tree suggests that it may represent a previously unrecognized lineage worthy of a separate genus status. 
The genus Japelion Dall, 1916 currently includes several species with channelled suture. The type species (OD), Buccinum hirasei Pilsbry, 1901, belongs to the subfamily Parancistrolepidinae, as proved by molecular analysis and radular morphology (see Fig. 11D). Another conchologically very similar species, "Japelion" pericochlion (included only in our coxl tree; radula, see Habe \& Sato, 1973: fig. 14; shell see Fig. 10K herein) is clustering together with "Japelion" adelphicus and is nesting in the subfamily Beringiinae. Tritonium pericochlion is the type species of Metajapelion, and thus "Japelion" adelphicus is transferred to Metajapelion.

SUBFAMILY NEPTUNEINAE STIMPSON, 1865

(Figs 10L-O, 11A)

Type genus: Neptunea Röding, 1798

= Chrysodominae Dall, 1870. Type genus: Chrysodomus Swainson, 1840.

Included genera:

Aulacofusus Dall, 1918 (TS Fusus spitzbergensis Reeve, 1855 [= Fusus brevicauda Deshayes, 1832]; OD) ${ }^{(1)}$

Neptunea Röding, 1798 (TS Murex antiquus Linnaeus, 1758; SD, Sandberger (1861). Synonym: Chrysodomus Swainson, 1840; TS Murex despectus Linnaeus, 1758; SD, Cossmann (1901b: 98)) ${ }^{(1)}$

Diagnosis. Shell large, reaching $240 \mathrm{~mm}$, broadly fusiform, with high spire and short to medium-long, siphonal canal often bent abaxially. Protoconch paucispiral, moderately large. Whorl profile convex to distinctly shouldered. Shell sculpture pronounced in most species, spiral sculpture from microscopic threads to prominent bulging keels; axial sculpture rarely present, then of indistinct axial ribs or sometimes distinct, raised, axial lamellae producing prominent nodules at shoulder. Aperture very wide. Shell covered with smooth periostracum. Operculum large, spanning most of aperture, with terminal nucleus.

Radula with multicuspid ( $2-8$ cusps) central tooth with rectangular and anteriorly arcuate base; lateral teeth broad, with 2-7 cusps, outermost longest (Fig. 11A). Proboscis from long to very long and coiled within rhynchodaeum, thick, proboscis retractors from paired to multiple, attached laterally to median portion of rhynchodaeum, in Neptunea can pass through salivary glands. Paired medium-sized salivary glands. Gland of Leiblein from obsolete to medium large, tubular, valve of Leiblein from very small to large and rounded. Stomach large, with medium to long posterior mixing area.

Individual egg capsules large, of varying shape, usually with ornamented surface, aggregated in clusters of various shapes - ball-shaped, corn cob, or single-layered with capsules individually attached to substrate. Development direct, with nurse eggs, emerging molluscs large, reaching over $7 \mathrm{~mm}$ in SL (Pearse \& Thorson, 1967).

Distribution. Temperate northern Pacific through Arctic to temperate northern Atlantic, from subtidal to lower bathyal depths.

Remarks. In our multigene analysis, "Aulacofusus" hiranoi (Shikama, 1962) was recovered in a clade uniting buccinoideans from biogenic substrates (Eosiphonidae fam. nov.). 
1 However, in addition to "Aulacofusus" hiranoi, two specimens of a second species of the same

\section{Subfamily VolutopsiInaE HABE \& SATO, 1973}

(Figs 11H, 12A-D)

\section{Type genus: Volutopsius Mörch, 1857}

Included genera:

Habevolutopsius Kantor, 1983 (TS Volutopsius hirasei Pilsbry, 1907; OD) ${ }^{(1)}$

Lussivolutopsius Kantor, 1983 (TS Lussivolutopsius hydractiniferus Kantor, 1983; OD) ${ }^{(1)}$ Pyrulofusus Mörch, 1869 (TS Fusus deformis Reeve, 1847; M) ${ }^{(1)}$

Volutopsius Mörch, 1857 (TS Fusus largillierti Petit de la Saussaye, 1851 [= Strombus norwegicus Gmelin, 1790]; M) (1)

Diagnosis. Shell large, reaching $160 \mathrm{~mm}$, from fusiform to broadly fusiform or ovate, with very short to medium high spire and short to very short, nearly obsolete siphonal canal. Protoconch paucispiral, always retained in adults, of about two whorls, medium sized (3.5-5 $\mathrm{mm}$ in diameter) to very large (up to $13 \mathrm{~mm}$ ). Whorl profile convex to subcylindrical. Shell sculpture pronounced in most species, spiral sculpture from microscopic threads to prominent bulging keels; axial sculpture sometimes present, from knobs on shoulder and axial lamellae (some species of Volutopsius) to distinct axial ribs. Shell covered with smooth periostracum. Aperture ovate, wide, often with strongly calloused inner lip. Shell colour from ivory to orange or darkbrown, parietal callus and/or inside aperture often light- to dark-brown. Operculum small to medium-sized, spanning half of aperture or less, with terminal nucleus shifted leftwards.

Radula (Fig. 11H) with multicuspid (3-8 cusps) central tooth, with rectangular or nearly square, anteriorly arcuate, base; laterals varying in width from narrow to broad, typically with 2 cusps of varying length and rarely with indistinct intermediate cusplet. Proboscis from short to long, proboscis retractors multiple, attached laterally to median portion of rhynchodaeum. Paired salivary glands large, rarely fused. Gland and valve of Leiblein absent. Stomach variable, from sac-like with large posterior mixing area, to expanded, tubular, with very short mixing area. (Anatomy description based on Kantor, 1990).

Individual egg capsules very large, from 16 to $66 \mathrm{~mm}$ in diameter, hemisphaerical to lenticular, solitary, usually smooth, covered by thin chalky layer when newly laid. Development direct, with very few nurse eggs and a large amount of proteinaceous substance filling the capsule, emerging molluscs large to very large, reaching $19.5 \mathrm{~mm}$ in SL [Pyrulofusus harpa (Mörch, 1857), see Cowan (1965)]. 
Distribution. Temperate northern Pacific through Arctic to temperate northern Atlantic from subtidal to upper bathyal depths.

\section{SUBFAMILY PARANCISTROLEPIDINAE HABE, 1972}

(Figs 11E, F, I, 12E-K)

Type genus: Parancistrolepis Azuma, 1965.

$=$ Brevisiphoniinae Lus, 1973. Type genus: Brevisiphonia Lus, 1973

= Ancistrolepidinae Habe \& Sato, 1973. Type genus: Ancistrolepis Dall, 1895.

Included genera:

Ancistrolepis Dall, 1895 (TS Chrysodomus eucosmius Dall, 1891; OD) (1)

Bathyancistrolepis Habe \& Ito, 1968 (TS Chrysodomus trochoideus Dall, 1907; OD) ${ }^{(1)}$

Clinopegma Grant \& Gale, 1931 (TS Buccinum unicum Pilsbry, 1905; OD) ${ }^{(1)}$

Japelion Dall, 1916 (TS Buccinum hirasei Pilsbry, 1901; OD) ${ }^{(1)}$

Neancistrolepis Habe \& Sato, 1973 (TS Ancistrolepis beringianus Dall, 1919; OD) (2)

Parancistrolepis Azuma, 1965 (TS Japelion kinoshitai Kuroda, 1931; M) ${ }^{(1)}$; radula, see Habe (1972) (Fig. 13I, herein)

Pseudoliomesus Habe \& Sato, 1973 (TS Type species: Tritonium ooides Middendorff, 1848; OD) ${ }^{(1)}$

Thalassoplanes Dall, 1908 (TS: Troschelia moerchi Dall, 1908; OD) ${ }^{(1)}$. Synonym: Brevisiphonia Lus, 1973 (TS Brevisiphonia circumreta Lus, 1973 [= Thalassoplanes moerchii]; OD)

Diagnosis. Shell medium-sized to large, reaching $120 \mathrm{~mm}$, from oval with very short spire to fusiform with high spire. Shell base obliquely truncated, without defined siphonal canal but with siphonal notch of varying depth. Protoconch of 2.5-3 whorls, large, diameter up to $3 \mathrm{~mm}$. Whorl profile from evenly convex to angulated at shoulder. Suture canaliculate in Japelion. Shell sculpture pronounced in most species, spiral sculpture from microscopic threads to prominent bulging keels; axial sculpture limited to growth lines, sometimes thickened and forming reticulated pattern at intersection with spiral cords. Shell covered with smooth or ciliated periostracum, whitish to light brown; inside of aperture white. Operculum large, spanning most of aperture, sometimes exceeding its length, narrow, with terminal nucleus and detached along most of its length, or very small (Parancistrolepis only), spanning about 1/5 of aperture length (Fig. 12K).

Central tooth in most species with rectangular and anteriorly arcuate to notched base; lateral teeth most often with three cusps, outermost longest, sometimes with additional intermediate cusps (Fig. 11F). In Thalassoplanes (Fig. 11E) central tooth very narrow and long, lateral teeth broad, with 7 or 8 short cusps of subequal length. Proboscis from long to very long and coiled within rhynchodaeum, thick to thin; proboscis retractors from paired to multiple, attached laterally to posterior portion of rhynchodaeum. Salivary glands medium-sized, fused. Gland of Leiblein large, extended, tubular and coiled, valve of Leiblein large. Stomach large, with medium-sized posterior mixing area. 
Egg capsules solitary, large, elongate-oval with very long stalk. Capsule smooth, length 52-60 mm, with stalk 195-205 mm. On concave side of capsule there is an operculum for the release of hatching juveniles. Newly laid capsule filled by white proteinous substance. Stalk rounded in section and triangular at its base, expanding into irregularly shaped flattened plate, attaching to substrate. Up to 8 embryos per capsule, ready to hatch juveniles with SL 8.5-9.5 mm (Kantor, 1988).

Distribution. Temperate northern Pacific from subtidal to abyssal depths.

Remarks. Our multigene dataset did not include any Ancistrolepis species, but in the cox 1based tree Ancistrolepis grammatus (Dall, 1907) (Fig. 12E) clusters with other members of the subfamily, being sister with maximal support to Clinopegma unicum, the type species of Clinopegma.

Similarly Parancistrolepis was included only in the coxl-based tree and clustered with maximal support with Thalassoplanes. The radula of Parancistrolepis (Fig. 13I) shows some similarity to that of Thalassoplanes (Fig. 13E), but differs in the morphology of the central tooth. Theefore the name Parancistrolepidinae Habe, 1972 (original spelling Parancistrolepisinae) has priority over Ancistrolepidinae Habe \& Sato, 1973. The subfamily was raised to family level by Goryachev (1987) who included in it Parancistrolepis, Thalassoplanes, and Brevisiphonia.

SUBFAMILY SIPHONALIINAE FINLAY, 1928

(Figs 13, 14)

Type genus: Siphonalia A. Adams, 1863.

Included genera:

Bayerius Olsson, 1971 (TS Fusinus fragilissimus Dall, 1908; OD) ${ }^{(1)}$

Japeuthria Iredale, 1918 (TS Buccinum ferreum Reeve, 1847; OD) ${ }^{(1)}$

Mohnia Friele, 1878 (TS Fusus mohni Friele, 1877; M) (2)

Pararetifusus Kosuge, 1967 (TS Phymorhynchus tenuis Okutani, 1966; OD) (1)

Phaenomenella Fraussen, 2006 (TS Manaria inflata Shikama, 1971; OD) ${ }^{(1)}$

Siphonalia A. Adams, 1863 (TS Buccinum cassidariaeforme Reeve, 1846; SD, Cossmann, $1889)^{(1)}$

Diagnosis. Shell small $(10 \mathrm{~mm}$ ) to medium large (over $60 \mathrm{~mm}$ ), very thin-walled and fragile to robust, oval to broadly fusiform. Protoconch paucispiral, sometimes large and bulbous (Phaenomenella), sometimes with small smooth initial part, followed by strong axial and spiral sculpture on the upper teleoconch whorls, forming a reticulated pattern (Mohnia, Bayerius). Whorl outline from evenly, gently or strongly convex, to distinctly shouldered. Spiral sculpture always present, of uniform or unequal spiral cords. Axial sculpture present at least on upper whorls in Phaenomenella and Siphonalia, represented by low, rounded ribs, stronger on earlier whorls, on later whorls more pronounced at shoulder. Aperture wide to very wide. Siphonal canal short to moderately long, often bent abaxially. Operculum from oval paucispiral to elongate with terminal nucleus.

Radula (Fig. 14) comprising central tooth with rectangular base notched anteriorly and 3 cusps; lateral teeth with 2-4 cusps, typically 3, central shortest. Proboscis medium-long to long, proboscis retractors multiple, attach laterally to central portion of rhynchodaeum. Paired large 
salivary glands. Gland of Leiblein very large, valve of Leiblein well defined. Stomach with long to very long posterior mixing area (based on anatomical description in Kantor et al. (2020a, 2020b).

Distribution. Temperate northern Atlantic and Arctic to temperate northern Pacific at upper subtidal to hadal depths.

Remarks. The subfamily Siphonaliinae was originally erected as a subfamily of Buccinulidae and, in addition to the type genus, included Penion, Aeneator and Glaphyrina. Later molecular phylogenetic analyses (Vaux et al., 2017; Kantor et al., 2020a) have shown that none of these latter genera is phylogenetically close to Siphonalia. Neither are they close to each other and all three are here placed in different families. The family name Siphonaliidae was again independantly established by Goryachev (1987: 33, 35).

Based on the sequences of three genes (cox1, 16S, and H3) Japeuthria ferrea is here confidently placed in the subfamily (Fig. S2), where it is recovered in a sister position to all other taxa. These taxa are in turn form two maximally supported clades, one uniting representatives of Siphonalia and Phaenomenella, and the other all remaining genera. The affinity of Japeuthria and Siphonalia has previosuly been proposed by Hayashi (2005) based on the analysis of a 1,3 $\mathrm{Kb}$ fragment of16S rRNA, while the close relationship of Mohnia dalli, Pararetifusus and Bayerius to the genera Siphonalia and Phaenomenella was shown and briefly discussed in Kantor et al. (2020b).

The taxonomic position of Mohnia dalli (Friele, 1881) needs an additional remark. Originally described in the genus Sipho Klein, 1753 (an unavailable name), it was transferred to Turrisipho Dautzenberg \& H. Fischer, 1912 by Bouchet \& Warén (1985). The radula remains unknown. We tentatively transfer it to Mohnia based on overall shell similarity, paucispiral operculum (Kantor et al., 2020b) and similar protoconch morphology (for the protoconch of $M$. mohni, see Bouchet \& Warén, 1985: fig. 531, of M. dalli, fig. 559).

\section{UNASSIGNED BUCCINIDAE}

In our multigene analysis type species of Anomalisipho, A. verkruezeni constitutes its own branch, while in coxl based tree it is clustering together with P. rhyssus (Dall, 1907) and «Colus» kujianus Tiba, 1973 with maximal support (Fig. S1). Due to very limited material we abstain at the moment of taking taxonomic decision, but these genera may constitute a separate subfamily.

Anomalisipho Dautzenberg \& H. Fischer, 1912 (TS Sipho verkruezeni Kobelt, 1876; OD) ${ }^{(1)}$ (Figs 13G, 14K, L)

Remark. The type species of Anomalisipho from the subtidal depths of the northern Atlantic is included in the analysis and ends up isolated in the tree, forming a long branch sister to Buccinum, albeit without support. The radula of Anomalisipho virgata (Friele, 1879) (Fig 13G), a morphologically very similar species, is similar to the radulae encountered in different genera, e.g. Aulacofusus, Clinopegma, Ancistrolepis, Buccinum and others, and thus does not clarify the position of the genus. The operculum, with terminal nucleus, differs from the operculum of Buccininae with subcentral nucleus, and speaks against including Anomalisipho in that subfamily. In the expectation of additional data, we refrain from allocating Anomalisipho to any subfamily. 
1

2

3

4

5

6

7

8

9

10

11

12

13

14

15

16

17

18

19

20

21

22

23

24

25

26

27

28

29

30

31

32

33

34

35

36

37

38

39

40

41

42

43

44

45

Plicifusus Dall, 1902 (TS Fusus kroeyeri Møller, 1842; OD) ${ }^{(1)}$

(Fig. 12N)

Remark. The single species, P. rhyssus (Dall, 1907) was included in coxI based analysis and clusters together with Anomalisipho verkruezeni and "Colus" kujianus Tiba, 1973. Plicifusus is species rich and morphologically variable genus, including about dozen of species and is distributed in the Arctic and north Pacific (Kosyan, Kantor, 2012). Its radula is very similar to that of Anomalisipho. "Colus" kujianus according to our tree clearly does not belong to Colus. In shell characters (Fig. 12O) it resembles both Plicifusus (Fig. 12N) and Anomalisipho. Its generic placement is not defined yet pending the results of multigene analysis.

\section{BUCCINIDAE INSERTAE SEDIS}

As circumscribed herein the family Buccinidae includes mostly boreal and, to a lesser extent, temperate to subtropical taxa of Northern Hemisphere Buccinoidea. Notwithstanding, there remains numerous, sometimes common, boreal genera that the lack of suitable material prevented us from including in the molecular analysis. Among them are Troschelia Mörch, 1876, Helicofusus Dall, 1916, and Latisipho Dall, 1916. Their taxonomic position remain uncertain, since shell and radula characters that were the basis for earlier placement appear to be weakly informative due to their high homoplasy.

Besides, representatives of two nominal subfamilies described within Buccinidae are not present in our analysis and therefore their status remains unconfirmed.

SUBFAMILY LIOMESINAE P. FISCHER, 1884

(Fig. 14O)

= Buccinopsidae G. O. Sars, 1878 (invalid: type genus [Buccinopsis Jeffreys, 1867] a junior homonym)]

Type genus: Liomesus Stimpson, 1865 (TS †Buccinum dalei J. de C. Sowerby, 1825; OD). Synonym: Buccinopsis Jeffreys, 1867 (TS †Buccinum dalei; M)

Remarks. The radula of Liomesus ovum (Turton, 1825), was illustrated by G.O. Sars (1878: tab. X, fig. 15) as Buccinopsis eburnea (M. Sars, 1851). It is characterized by acuspate subrectabgular central tooth and unicuspidate lateral ones. This morphology is very different from other buccinoidean radulae, and has led Habe \& Sato (1973) to suggest close relationships to Beringius, which was included by them together with Liomesus in the subfamily Liomesusinae. Bouchet \& Warén (1985: fig. 461) provided a line drawing of a very different radula of Liomesus ovum, from an egg capsule, with muticuspidate central and lateral teeth. Because of this ambiguity, and the lack of molecular and anatomical data, we cannot propose any plausible hypothesis on the position of Liomesus.

SUBFAMILY TRUNCARIINAE COSSMANN, 1901

(Fig. 14M) 
Type genus: Truncaria A. Adams \& Reeve, 1850 (TS Buccinum filosum A. Adams \& Reeve, 1850; M)

Remarks. The anatomy and radula of the type (and only included) genus remains unstudied (Olsson, 1971) and molecular data are lacking as well. The peculiar shell shape (Fig. 14M) does not provide any clue on the possible relationships of Truncaria, and even its position within Buccinidae remains to be confirmed.

FAMILY FASCIOLARIIDAE GRAY, 1853

SUBFAMILY FASCIOLARIINAE GRAY, 1853

Type genus: Fasciolaria Lamarck, 1799 (TS Murex tulipa Linnaeus, 1758; M)

= Latiridae Iredale, 1929. Type genus Latirus Montfort, 1810 (TS Latirus aurantiacus Montfort, 1810; OD).

\section{SUBFAMILY FUSININAE WRIGLEY, 1927}

Type genus: Fusinus Rafinesque, 1815 (TS Murex colus Linnaeus, 1758; by typification of replaced name [Fusus Bruguière, 1789])

= Fusinae Swainson, 1840 (inv.). Type genus: Fusus Bruguière, 1789 (inv.) (TS Murex colus Linnaeus, 1758; by subsequent monotypy, Lamarck, 1799).

= Cyrtulidae MacDonald, 1869. Type genus: Cyrtulus Hinds, 1843 (TS Cyrtulus serotinus Hinds, 1843; M).

\section{SUBFAMILY PERISTERNIINAE TRYON, 1880}

Type genus: Peristernia Mörch, 1852 (TS Turbinella nassatula Lamarck, 1822; SD, Martens, 1868)

Remarks. The 5-gene molecular phylogeny of the Fasciolariidae of Couto et al. (2016) revealed four major lineages. Three of these cluster together and are generally consistent with the widely accepted subfamilies Peristerniinae, Fasciolariinae and Fusininae (the latter further analysed by Kantor et al., 2018), but with a significantly altered content mostly due to the transfer of several genera from Peristerniinae to the other two subfamilies. The analysis is congruent with that of Couto et al. (2016), the results of which are followed here with additions and corrections based on Kantor et al. (2018).

Vaux et al. (2017) attributed Pararetifusus to the Fasciolariidae, based on the erroneous assignment of Microfulgur carinatus Ponder, 1970 to Pararetifusus. Our analysis demonstrates that M. carinatus belongs to the Fasciolariidae (Fusininae), while Pararetifusus, represented in our dataset by its type species $P$. tenuis, belongs to the Buccinidae (Siphonaliinae). 
The morphology, anatomy and radula of a number of species of Fasciolariidae were recently described in detail by Couto \& Simone (2019). For the genus level taxonomy, see Snyder \& Callomon (2021).

FAMILY BUSYCONIDAE WADE, 1917 (1867)

(Figs 15A-C, 16A, B)

SUBFAMILY BUSYCONINAE WADE, 1917 (1867)

Type genus: Busycon Röding, 1798

= Fulguridae Stoliczka, 1867. Type genus Fulgur Montfort, 1810.

Included genera:

Busycoarctum Hollister, 1958 (TS Pyrula coarctata G.B. Sowerby I, 1825; OD) (3)

Busycon Röding, 1798 (TS Busycon muricatum Röding, 1798 [= Murex carica Gmelin, 1791];

SD, B. Smith, 1938). Synonym: Fulgur Montfort, 1810 (TS Fulgur eliceans Montfort, 1810; OD) ${ }^{(1)}$

Lindafulgur Petuch, 2004 (TS $\uparrow$ Busycon lindajoyceae Petuch, 1991; OD) (3)

Sinistrofulgur Hollister, 1958 (TS Busycon sinistrum Hollister, 1958; OD) ${ }^{(3)}$

SubFAmily BusycotypinAe PetuCh, 1994

Type genus Busycotypus Wenz, 1943

Included genera:

Busycotypus Wenz, 1943 (TS Murex canaliculatus Linnaeus, 1758; OD) ${ }^{(1)}$

Fulguropsis Marks, 1950 (TS Bulla pyrum Dillwyn, 1817; OD) ${ }^{(1)}$

Diagnosis. Shell large to very large (over $400 \mathrm{~mm}$ ), dextral or sinistral, with low or very low spire and long siphonal canal. Protoconch paucispiral, medium-sized. Suture often canaliculated. Spire whorls shouldered, or concave due to wide concave shoulder slope terminating at lower suture. Spiral sculpture often with a keel on shoulder, and uniform or unequal spiral cords on rest of the whorl. Axial sculpture present or absent, of knobs or tubercles on shoulder. Aperture high, elongate-pyriform due to broad siphonal canal. Periostracum from thin to thick, ciliated. Operculum large and thick, spanning most of aperture, leaf shaped with terminal nucleus.

Radula (Fig. 16A, B) with central tooth with rectangular base, deeply arcuated anteriorly and bearing 3-5 subequal cusps on posterior edge; lateral teeth with 3 or 4 cusps, outermost longest, intermediate much shorter. Proboscis long and thick, posteriorly with a septum, isolating the proboscis inner cavity from body haemocoel, salivary ducts and oesophagus passing through septum (Kosyan \& Kantor, 2004). Proboscis retractors multiple, attached laterally to posterior portion of rhynchodaeum. Paired medium-sized salivary glands. Gland of Leiblein from small and narrow, tubular to large and folded, terminating in ampulla; valve of Leiblein well defined. Stomach with posterior mixing area medium-long to long (Kantor, 2003). 
Individual oval egg capsules with sculptured surface and short stalk forming long string egg clusters. Development intracapsular.

Distribution. Tropical and temperate western North Atlantic, from intertidal to shelf edge.

Remarks. The subfamilial and generic classification follows Petuch et al. (2015).

\section{FAMILy Buccinanopsidae GALINDO, PUILlANDRE, LOZOUET \& BOUCHET, 2016 (NEW RANK)}

(Figs 15D, 16I)

Type genus: Buccinanops d'Orbigny, 1841

Included genera:

Buccinanops d'Orbigny, 1841 (TS Buccinum cochlidium Dillwyn, 1817; OD) ${ }^{(1)}$

Diagnosis. Shell thick-walled, medium-large, buccinoid, with low to moderately high spire and distinct siphonal notch giving it a truncated appearance. Protoconch large, smooth, paucispiral, of about 1.5-2.5 whorls. Whorl profile usually evenly convex, or with bulging subsutural keel, but occasionally rather flat. Sculpture lacking or represented by axial ribs on early teleoconch whorls, and later mainly by growth lines, occasionally with spines on shoulder. Siphonal canal very short, robust, heavily calloused, usually demarcated from shell base by furrow or narrow depression, Inner aperture lip with strongly developed parietal callus, and terminal columellar fold. Operculum large, leaf-shaped, with smooth margins and terminal nucleus.

Radula (Fig. 16I) with multicuspidate arcuated central tooth with 7-9 cusps decreasing abaxially in size, one prominent cusp, not always the central one. Lateral teeth with $3-5$ cusps, intermediate(s) much shorter that longest outer and inner ones.

Anatomy (after Simone, 1996). Foot with a single metapodial tentacle. Adults eyeless. Proboscis long to very long, proboscis retractors numerous, lateral. Valve of Leiblein vestigial, gland of Leiblein small, tubular. Salivary glands small, not fused. Stomach not large, with short posterior mixing area. Non-planktotrophic development.

Distribution. Temperate waters of South America, intertidal.

Remarks. The genus Buccinanops was traditionally (Cernohorsky, 1984) included in the nassariid subfamily Dorsaninae and segregated as a separate subfamily by Galindo et al. (2016). In the phylogeny of Galindo et al., Buccinanops was recovered as sister to all the other Nassariidae. In our analysis, however, it is sister to Macron and together with it form a highly supported clade with Busyconidae, none of which were included in Galindo et al.'s analysis.

\section{FAMILY COMINELLIDAE GRAY, 1857}

(Figs 15E-J, 16C-E)

Type genus: Cominella Gray, 1850

Included genera:

Cominella Gray, 1850 (TS Buccinum testudineum Bruguière, 1789 [= Buccinum maculosum Martyn, 1784]; SD, Iredale, 1918) (1)

Falsitromina Dell, 1990 (TS Tromina bella Powell, 1951, OD) (2); radula, see Powell (1951) 
Lusitromina Harasewych \& Kantor, 2004 (TS Tromina abyssorum Lus, 1993, OD) (2); radula, see Harasewych \& Kantor (2004)

Pareuthria Strebel, 1905 (TS Fusus plumbeus Philippi, 1844 [= Pareuthria fuscata (Bruguière, 1789)]; SD, Tomlin, 1932) ${ }^{(1)}$

Parficulina Powell, 1958 (TS Notoficula problematica Powell, 1951, OD) ${ }^{(2)}$ : radula, see Powell (1951)

Diagnosis. Shell from small $(5 \mathrm{~mm}$ ) to medium-sized (to $75 \mathrm{~mm}$ ), from broadly-ovate to elongate oval or nearly biconical, with very short siphonal canal and often distinct siphonal notch. Protoconch paucispiral. Shoulder from weakly defined to distinct, with concave subsutural ramp. Axial sculpture absent or represented by rounded ribs, strongest on shoulder and whorl periphery. Spiral sculpture absent or composed of cords or striae varying in strength and number per whorl; cancellate sculpture rarely present. Operculum with terminal nucleus or paucispiral.

Radula (Fig. 16C-E) with central tooth almost square, deeply notched on anterior margin, with three closely spaced cusps; bicuspid lateral teeth with subequal cusps, or outer cusp longer.

Distribution. Intertidal to abyssal depths in the Southern Hemisphere: Magellanic region, New Zealand, Antarctica.

Remarks. Powell initially considered Cominellidae as a full family (Powell, 1929), but later (Powell, 1951) treated it as a subfamily of Buccinulidae, a viewpoint followed by many later authors (e.g., Harasewych \& Kantor, 2004; Pastorino, 2016). Our analysis clearly demonstrates that this clade deserves family rank and is not closely related to Buccinulidae.

Only two genera (Cominella and Pareuthria) were included in our analysis, while three others are included in the family merely based on radular characters. However, similar radulae with bicuspid lateral teeth and tricuspid central ones are also found in unrelated Buccinoidea (e.g. in Phos, Photinae) and the aforementioned genera may in fact belong to other family(ies).

Kantor \& Harasewych (2013) argued that most Antarctic species attributed to Pareuthria (Dell, 1990; Numanami, 1996) in fact belong to Falsimohnia (confirmed herein to be a Prosiphonidae) and Strebela (suggested herein to be a Prosiphonidae), both restricted to the area of the Antarctic convergence. The position of Pareuthria turriformis Egorova, 1982 from the Ross Sea was considered doubtful since its anatomy was not studied and its shell does not resemble any other species of Pareuthria. Our molecular analysis, nevertheless, confirmed that this species is closely related to P. fuscata, the type species of the genus, and thus we confirm the inclusion of $P$. turriformis in Pareuthria.

\section{FAMILY RETIMOHNIIDAE FAM. NOV.}

(Figs $15 \mathrm{~K}-\mathrm{O}, 16 \mathrm{~F}-\mathrm{H}$ )

Type genus: Retimohnia McLean, 1995

Included genera:

Fusipagoda Habe \& Ito, 1965 (TS Mohnia exquisita Dall, 1913; OD) ${ }^{(1)}$

Retifusus Dall, 1916 (TS Tritonium jessoense Schrenck, 1867; OD) (2); radula, see Kosyan \& Kantor (2014) 
Retimohnia McLean, 1995 (TS Mohnia frielei Dall, 1891; OD) (1)

Diagnosis. Shell thin-walled, small to medium-sized, 12-37 $\mathrm{mm}$ in adults, oval to narrowly fusiform, with moderately long to long siphonal canal. Teleoconch whorls convex or shouldered. Axial sculpture usually present at least on earlier whorls, of prominent rounded axial ribs. Spiral sculpture typically of numerous, closely spaced, cords, sometimes with strong keel on shoulder. Shell pale, yellowish or light brown, due to thin periostracum; inside of aperture white. Operculum oval, paucispiral or with adaxial terminal nucleus.

Radula (Fig. 16F-H). Central tooth with 3-6 cusps and deeply anteriorly notched basal plate. Lateral teeth with 3-5 (typically 3) cusps. Proboscis short, gland of Leiblein large, valve of Leiblein well developed. Salivary glands moderately developed or large, sometimes fused. Stomach large, with small or moderately large posterior mixing area.

Distribution. North Pacific, northwards from Oregon along the American coast, and northwards from Japan to Chukchi Sea on the Asian side, from subtidal to abyssal depths.

Remarks. The genera that are included in the family were previously classified in the subfamily Colinae (then included in Buccinidae - Kosyan \& Kantor, 2014, 2016). Our analysis clearly demonstrates that they are related neither to Colidae nor to Buccinidae. Their position in the phylogeny of Buccinoidea as a clade sister to Cominellidae is only marginally supported.

The only specimen of Fusipagoda included in the analysis represents a species new to science. It differs from other species of Fusipagoda (for review, see Kosyan \& Kantor, 2015) in the presence of axial sculpture and we attribute it to the genus with some doubts; consequently, the allocation of Fusipagoda in the family Retimohniidae is itself a little doubtful.

The anatomy of Retimohnia and Retifusus was recently described by Kosyan \& Kantor (2014, 2016).

\section{FAMILY AUSTROSIPHONIDAE COTTON \& GODFREY, 1938}

(Figs 17A-E, 18A-E)

Type genus: Austrosipho Cossmann, 1906.

Included genera:

Antarctoneptunea Dell, 1972 (TS Fusitriton aurora Hedley, 1916; OD) (1)

Kelletia Bayle, 1884 (TS Fusus kelletii Forbes, 1852; M) ${ }^{(1)}$

Penion P. Fischer, 1884 (TS Fusus dilatatus Quoy \& Gaimard, 1833; M). Synonym after Ponder (1973): Austrosipho Cossmann, 1906 (TS †Fusus roblini Tenison Woods, 1876; OD; Miocene of South Australia) ${ }^{(1)}$

Serratifusus Darragh, 1969 (TS †Fusus craspedotus Tate, 1888; OD) ${ }^{(1)}$

Diagnosis. Shell medium-sized to very large, from 35 to $220 \mathrm{~mm}$ in adults, broad to narrowly fusiform, with moderately long to very long siphonal canal. Protoconch varying in size, reaching 4 whorls and nearly $4 \mathrm{~mm}$ in diameter. Teleoconch whorls evenly convex, shouldered or distinctly pagodiform. Axial sculpture usually present at least on adapical whorls, consisting of ribs, knobs or spines on shoulder, rarely absent (Antarctoneptunea aurora). Spiral sculpture of multiple cords varying in strength and density, rarely absent on subsutural ramp (Serratifusus). Operculum leaf shaped, with terminal nucleus. 
Radula (Fig. 18A-F). Central tooth with subrectangular, narrow to medium-broad, and anteriorly notched basal plate, usually bearing 3 cusps. Lateral teeth with 3-7 (most often three) cusps, outer one longest. Proboscis short to long, gland of Leiblein large, subdivided into compartments, valve of Leiblein well developed. Salivary glands large. Stomach either tubular, U-shaped, without posterior mixing area, or sac-like with small posterior mixing area.

Development with (Kelletia: Rosentahl, 1970) or without planktotrophic larvae.

Distribution. Antarctica, Australasia, tropical Pacific, western America from Baja California to Monterey Bay, Japan, in subtidal to bathyal depths.

Remarks. Since its original description, the family name Austrosiphonidae was rarely used as valid and appeared only in checklists without diagnosis or description (Macpherson \& Chapple, 1951; Iredale \& McMichael, 1962). Ponder (1973) considered it, together with Buccinulidae, a synonym of Buccinidae, and Bouchet et al. (2017) a synonym of Siphonaliinae. As demonstrated by our molecular analysis, all these groups constitute independent phylogenetic lineages.

A close relationship of Serratifusus to Penion had been suggested by Harasewych (1991). Vaux et al. (2017) for the first time revealed a close relationship between the Antarctic, initially monotypic, genus Antarctoneptunea and Penion benthicola Dell, 1956, and transferred the latter to Antarctoneptunea.

\section{FAMILY TUDICLIDAE COSSMANN, 1901}

(Figs 17F-P, 18G-L)

Type genus: Tudicla Röding, 1798

[= Buccinulidae Finlay, 1928. Type genus: Buccinulum Deshayes, 1830]

Included genera:

Aeneator Finlay, 1926 (TS Verconella marshalli Murdoch, 1924; OD) ${ }^{(1)}$

Afer Conrad, 1858 (TS Murex afer Gmelin, 1791; by tautonomy) ${ }^{(1)}$; radula, see Harasewych, 2018

Buccinulum Deshayes, 1830 (TS Murex lineatus Gmelin, 1791 [= Fusus linea Martyn, 1784]; SD, Iredale, 1921) ${ }^{(1)}$. Synonyms: Evarnula Finlay, 1926 (TS Cominella striata Hutton, 1875; OD); Chathamina Finlay, 1928 (TS Cantharus fuscozonatus Suter, 1908; OD)

Euthria Gray, 1850 (TS Murex corneus Linnaeus, 1758; SD [Art. 70.3], Petit, 2012) ${ }^{(1)}$

Euthriostoma Marche-Marchad \& Brébion, 1977 (TS Euthriostoma gliberti Marche-Marchad \& Brébion, 1977 [= Euthria saharica Locard, 1897]; OD) ${ }^{(2)}$; radula, see Bouchet \& Warén, 1986

Lirabuccinum Vermeij, 1991 (TS Buccinum dirum Reeve, 1846, OD) (2); radula, see Callomon \& Lawless, 2013

?Siphonofusus Kuroda \& Habe, 1954 (TS Siphonalia lubrica Dall, 1918; M) (2); radula, see Shuto, 1978

Tasmeuthria Iredale, 1925 (TS Siphonalia clarkei Tenison Woods, 1876; OD) ${ }^{(1)}$; radula, see Cooke, 1917

Tudicla Röding, 1798 (TS Murex spirillus Linnaeus, 1767; SD, Angas, 1878) ${ }^{(1)}$; radula, see Harasewych, 2018 
1 Diagnosis. Shell medium-sized to medium-large, from 10 to about $100 \mathrm{~mm}$ in adults, with very short to very long siphonal canal, sometimes twisted or strongly inclined abaxially. Protoconch paucispiral, usually large to very large and bulbous. Axial sculpture usually present at least on adapical whorls, of rounded axial ribs or knobs varying in strength, rarely absent. Spiral sculpture completely absent, or represented by striae or cords of variable strength and density. Outer aperture lip smooth or lirate inside, inner lip calloused, sometimes bearing a parietal knob. Operculum oval, with terminal nucleus.

Radula (Fig. 18G-L) with trapezoidal central tooth, medium- to deeply arcuated anteriorly, and with attenuated narrow posterior portion bearing three closely spaced cusps. Lateral teeth with three strong cusps, outermost longest. Proboscis long, gland of Leiblein medium-large, subdivided into compartments, valve of Leiblein well developed. Salivary glands large, salivary ducts embedded in oesophagus wall. Stomach broad tubular, U-shaped, without posterior mixing area (in Buccinulum).

Distribution. Tropical (West Africa) and temperate (Mediterranean) Atlantic, tropical Indo-Pacific, northern Pacific, subtidal to upper bathyal depths.

Remarks. The subfamily Tudiclinae was classified in the Turbinellidae until Harasewych (2018) provided data on the anatomy and radula of Tudicla spirillus, the type species of the monotypical type genus, and transferred it to the Buccinoidea. He also pointed to strong similarities between Tudicla, Afer, Euthria and Euthriostoma.

Representatives of Tudicla (T. spirillus), Afer (Afer cumingii (Reeve, 1848)) and Africofusus Vermeij \& Snyder, 2018 (A. africanus (G. B. Sowerby III, 1897)) were included in our extended coxl analysis and fall in the same clade as Buccinulum. Similarly, based on the sequence of $16 \mathrm{~S}$ gene, Afer cumingii was recovered as sister to Buccinulum in the analysis of Li et al. (2013). The radulae of Afer (Fig. 18L) and Tudicla are very similar to those of Euthria and Buccinulum (Li et al., 2013; Fraussen \& Hadorn, 2000; Harasewych, 2018), having a characteristic and unique central tooth, leaving no doubt that Tudicla, Afer, and Buccinulum belong to the same family. The name Tudiclidae Cossmann, 1901 has priority over Buccinulidae Finlay, 1928.

The position of Africofusus (TS Fusus ocellifer Lamarck, 1816; OD) remains doubtful due to the lack of molecular data and radula description for the type species, which is conchologically rather different from the sequenced $A$. africanus and may be not congeneric. Vermeij \& Snyder (2018) only conditionally attributed Fulgur africanus to the genus.

The extension of the family Tudiclidae (as Buccinulidae Finlay, 1928) has drastically changed over time. Beside Buccinulum, the Recent genera Evarnula Finlay, 1926, Chathamina Finlay, 1928, and Tasmeuthria Iredale, 1925 were originally placed by Finlay in the family, and all three were later considered synonyms of Buccinulum by Ponder (1971).

Powell (1951) extended the scope of the family to encompass the entire radiation of Southern Hemisphere Buccinoidea. However, Vaux et al. (2017) demonstrated that southern buccinoideans are not monophyletic, a conclusion corroborated by our analysis. Tudiclidae as circumscribed herein includes species from both the Southern and Northern Hemispheres.

The genus Euthria in its current scope is conchologically very heterogeneous and our analysis did not recover it monophyletic. The species of Euthria included in our analysis form two clades. The first one (to which the name Euthria can be restricted) includes the type species, E. cornea, E, japonica, and E. walleri. The second one includes Tasmeuthria clarkei (Tenison Woods, 1876) (TS of Tasmeuthria), and a subclade comprising "Euthria" scepta, "E." 
cummulata and "E." solifer. Tasmeuthria was synonymized with Buccinulum by Ponder (1971), but our analysis demonstrates that it is worthy of a full generic status. However, T. clarkei (Fig. $17 \mathrm{~J}$ ) is conchologically very different from the other three species (see, e.g., Fig. 17M), in particular in having a much shorter siphonal canal. Therefore, it is possible that "Euthria" scepta, "E." cummulata and "E." solifer should be classified in a different genus. One possible name for this subclade is Siphonofusus, also previously considered a synonym of Euthria. The type species, S. lubrica, possesses a medium-long canal inclined abaxially, and is conchologically rather similar to E. solifer. Furthermore, S. lubrica possesses a radula similar to other Tudiclidae species (Shuto, 1978). The validity of Siphonofusus is at present not confirmed, pending molecular data, but we tentatively include it as valid genus of Tudiclidae.

Buccinulum was recovered monophyletic neither in our, nor in Vaux et al. (2017) analyses. Its taxonomy can not be resolved at the moment, since the type species of the genus was not included in the analysis.

Lirabuccinum had been considered closely realted to Buccinulum by Vermeij (1991). In the revision of the genus by Callomon and Lawless (2013), the radulae of several species were illustrated. Whereas the radula of the type species, L. dirum, is similar to that in Tudiclidae (Callomon \& Lawless, 2013: fig. 18), the radula of Lirabuccinum musculus Callomon \& Lawless, 2013 (fig. 21) is markedly different in the shape of the central tooth and L. musculus may not be congeneric with $L$. dirum. Pending molecular data, we tentatively attribute the genus to Tudiclidae after Vermeij (1991).

\section{FAMILY MELONGENIDAE GILL, 1871 (1854)}

Type genus: Melongena Schumacher, 1817

= Cassidulidae Gray, 1854 (inv.). Type genus: Cassidulus Gray, 1854

= Galeodidae Thiele, 1925 (inv.). Type genus: Galeodes Röding, 1798

= Volemidae Winckworth, 1945. Type genus: Volema Röding, 1798

= Heligmotomidae Adegoke, 1977. Type genus: Heligmotoma Mayer-Eymar, 1896]

Included genera:

Brunneifusus Dekkers, 2018 (TS Murex ternatanus Gmelin, 1791; OD) (3)

Heligmotoma Mayer-Eymar, 1896 (TS †Melongena nilotica Mayer-Eymar, 1896; M) (3)

Hemifusus Swainson, 1840 (TS Fusus colosseus Lamarck, 1822; SD, Gray, 1847) ${ }^{(1)}$

Lenifusus Dekkers, 2018 (TS Pyrula elongata Lamarck, 1822; OD) ${ }^{(3)}$

Melongena Schumacher, 1817 (TS Melongena fasciata Schumacher, 1817 [= Murex melongena

Linnaeus, 1758]; M). Synonym: Galeodes Röding, 1798 (TS Murex melongena Linnaeus, 1758; SD, Dall, 1906) ${ }^{(1)}$

Pugilina Schumacher, 1817 (TS Murex morio Linnaeus, 1758; SD, Herrmannsen, 1848).

Objective synonym: Cassidulus Gray, 1854 (TS Murex morio Linnaeus, 1758; M]) ${ }^{(1)}$

Saginafusus Wenz, 1943 (TS Fusus pricei E.A. Smith, 1887; OD) (3)

Taphon H. Adams \& A. Adams, 1853 (TS Fusus striatus G.B. Sowerby I, 1833; M) (3)

Volegalea Iredale, 1938 (TS Volegalea wardiana Iredale, 1938; OD) (3)

Volema Röding, 1798 (TS Volema paradisiaca Röding, 1798; SD, Iredale, 1917) ${ }^{(3)}$ 
1 Diagnosis. Shell medium-sized to very large, over $400 \mathrm{~mm}$, varying from broadly ovate with very short canal to fusiform with moderately long canal, or narrowly fusiform with very long siphonal canal. Protoconch paucispiral, medium-large. Axial sculpture from very weak to strong, from growth lines to prominent axial ribs, knobs or long spines on shoulder. Spiral sculpture represented by strong cords of variable strength. Aperture elongate, inner lip often with pronounced parietal callus. Shell colour varying from light to dark brown, sometimes with spiral bands; shell often covered with periostracum, sometimes very thick with axial lamellae and cilia. Operculum thick, large, spanning entire aperture, with terminal nucleus.

Radula (Fig. 22A) with central tooth with rectangular base, shallowly arcuate on anterior margin, and usually with three, broadly spaced, long cusps; lateral teeth bicuspid, with curved cusps, outer one longest. Head characteristically long, tubular, with short tentacles on its tip. Proboscis long, often coiled within rhynchocoel, valve and gland of Leiblein absent. Salivary glands medium-large, salivary ducts tightly attached to oesophagus on most of their length. Posterior oesophagus sometimes forming a pouch. Stomach broad, tubular, U-shaped, without posterior mixing area (Kantor, 2003).

Development direct. Irregularly oval egg capsules attached individually to substrate with short stalk, grouped in single-layered egg cluster.

Distribution. Tropical Atlantic, tropical and western Indo-Pacific at subtidal to lower shelf depths.

Remarks. The anatomy of several representatives was studied by Kosyan \& Kantor (2004) and Abbate \& Simone (2015).

\section{FAMILY PRODOTIIDAE FAM. NOV.}

(Figs 19, 20C-F)

Type genus Prodotia Dall, 1924

Included genera:

Caducifer Dall, 1904 (TS Triton truncatus Hinds, 1844; OD) (1)

Clivipollia Iredale, 1929 (TS Clivipollia imperita Iredale, 1929 [= Clivipollia pulchra (Reeve, 1846)]; M) ${ }^{(1)}$

Enzinopsis Iredale, 1940 (TS Engina gannita Hedley, 1914 [= Ricinula contracta Reeve, 1846]; OD) ${ }^{(3)}$

Falsilatirus Emerson \& Moffitt, 1988 (TS Falsilatirus pacificus Emerson \& Moffitt, 1988; OD) (3)

Minioniella Fraussen \& Stahlschmidt, 2016 (TS Minioniella heleneae Fraussen \& Stahlschmidt, 2016; OD) ${ }^{(3)}$

Prodotia Dall, 1924 (TS Phos billeheusti Petit de la Saussaye, 1853 [= Prodotia iostoma (Gray, 1833)]; OD) ${ }^{(1)}$

Speccapollia Fraussen \& Stahlschmidt, 2016 (TS Ricinula revurva Reeve, 1846; OD) ${ }^{(3)}$

Diagnosis. Shell small to medium-sized, varying from narrowly fusiform, nearly turriform to broadly biconic with short to medium long siphonal canal. Protoconch medium large, with up to 4 smooth, glossy whorls. Axial sculpture of broad rounded axial ribs of varying strength. Spiral sculpture of distinct, closely spaced cords forming spirally elongated nodules, or raised minute 
tubercles at intersection with spiral cords. Aperture ovate or elongated; outer aperture lip lirate, or distinctly denticulated; inner lip calloused, with parietal and anal knobs, often bearing denticles. Operculum with terminal nucleus.

Radula (Fig. 20C-F) of two types. In Prodotia (Fig. 20C, D), central tooth with broad arcuate base, with 5-9 cusps, sometimes with additional cusplets. Lateral teeth narrow, with very long outer cusp, bicuspid or with additional very small intermediate cusplet. In Clivipollia and Caducifer (Fig. 20E, F), central tooth with narrow subsquare base, arcuate on anterior margin, bearing three large cusps; lateral teeth tricuspid, outer cusp longest, intermediate cusp sometimes longer than inner cusp. Proboscis long, narrow, single large proboscis retractor emerging ventrally from posterior third of rhynchodaeum. Odontophore with radula relatively small, spanning anterior half of proboscis length. Valve of Leiblein well defined, gland of Leiblein expanded, tubular. Salivary glands medium-large to large, not fused. Salivary ducts tightly attached to oesophagus on most of their length.

Distribution. Tropical Indo-Pacific, tropical Atlantic, at intertidal to subtidal depths.

Remarks. The three genera attributed to the new family based on molecular data are rather heterogeneous conchologically as well as in radula morphology (Fig. 20). The radula of Caducifer is quite similar to that of some Pisaniidae, nevertheless differing consistently in central tooth morphology: in Pisaniidae the three central cusps are abutting much smaller cusps or serration, which are absent in Prodotiidae.

Four additional genera are attributed to Prodotiidae based on their conchological similarity to Clivipollia (Ponder, 1972; Fraussen \& Stahlschmidt, 2016). It is possible that broader taxonomic sampling of the Pisaniidae will result in the transfer of some other genera and species to the Prodotiidae. Due to the lack of support of the deeper nodes, the relationships of Prodotiidae are unclear.

\section{FAMILY CHAUVETIIDAE FAM. NOV.}

(Figs 20B, 21O, P)

Type genus: Chauvetia Monterosato, 1884

$=$ Lachesinae Bellardi, 1877. Type genus: Lachesis Risso, 1826 (invalid: junior homonym of Lachesis Daudin, 1803 [Reptilia])

= Donovaniidae T. L. Casey, 1904. Type genus: Donovania Bucquoy, Dautzenberg \& Dollfus, 1883 (invalid: junior homonym of Donovania Leach, 1814 [Crustacea])

= Chauvetiinae F. Nordsieck, 1968. Type genus: Chauvetia Monterosato, 1884 (not available; see Bouchet et al., 2017)]

Included genus:

Chauvetia Monterosato, 1884 (nom. nov. pro Nesaea Risso, 1826, non Lamarck, 1812, nec Leach, 1814) (TS Lachesis mamillata Risso, 1826; by typification of replaced name, Bucquoy, Dautzenberg \& Dollfus (1883). Synonyms: Lachesis Risso, 1826 (TS Lachesis mamillata Risso, 1826; M); Donovania Bucquoy, Dautzenberg \& Dollfus, 1883 (TS: Lachesis mamillata Risso, 1826; by typification of replaced name [Lachesis Risso, 1826]) (1) 
Diagnosis. Shell small, 5 to $13 \mathrm{~mm}$ in adults, narrowly fusiform, with high spire and very short siphonal canal. Protoconch small, paucispiral, of about 1.5 whorls, sculptured with spiral threads and in later part by axial ribs. Whorl outline convex; shoulder not pronounced. Axial sculpture of strong and closely spaced ribs, pronounced throughout whorl height. Spiral sculpture of distinct cords, forming nodules at intersection with axial ribs. Aperture oval, low, outer lip with denticles inside. Operculum spanning entire aperture, oval, with subcentral nucleus.

Central tooth (Fig. 20B) with square base and single large cusp, or cuspless. Lateral teeth with long and narrow attenuated outer portion of basal plate, forming "handle", and with 3 cusps, inner one shorter.

Distribution. Mediterranean and adjacent NE Atlantic from the English Channel to Senegal, intertidal to subtidal.

Remarks. The isolated position of Chauvetia was recognized by many authors, as reflected by three previous attempts to name the family, all of them invalid nomenclaturally. The complex taxonomic history and nomenclature of Chauvetia are discussed in detail by Gofas \& Oliver (2010).

Although molecular phylogenetic data clearly indicate that Chauvetiidae belongs to Buccinoidea, the realtionships of the family are not yet resolved due to lack of support of deeper nodes.

At least one species, Chauvetia tenuisculpta (Dautzenberg, 1891), was found parasitizing the sea star Oreaster clavatus Müller \& Troschel, 1842 (Oliver \& Rolán, 2008).

FAMILY PISANIIDAE GRAY, 1857

(Figs 21, 22)

Type genus: Pisania Bivona-Bernardi, 1832

[= Pusiostomatidae Iredale, 1940. Type genus: Pusiostoma Swainson, 1840 (TS Voluta mendicaria Linnaeus, 1758, SD, Herrmannsen, 1848 (in 1846-1852])]

Included genera:

Aplus De Gregorio, 1885 (TS †Murex plicatus Brocchi, 1814; SD, Vokes, 1971) ${ }^{(1,2)}$; see Aissaoui et al. (2016)

Cancellopollia Vermeij \& Bouchet, 1998 (TS Cancellopollia gracilis Vermeij \& Bouchet, 1998; OD) ${ }^{(1)}$

Cantharus Röding, 1798 (TS Buccinum tranquebaricum Gmelin, 1791; SD, Cossmann, 1889) (1)

Ecmanis Gistel, 1848 (TS Buccinum igneum Gmelin, 1791; by typification of replaced name, nom. nov. pro Proboscidea Möller, 1832, non Proboscidea Bruguière, 1791) ${ }^{(1)}$

Engina Gray, 1839 (TS Engina zonata Gray, 1839 [= Purpura turbinella Kiener, 1836]; SD, Gray, 1847) ${ }^{(1)}$

Gemophos Olsson \& Harbison, 1953 (TS Buccinum gemmatum Reeve, 1846, OD) (1)

Hesperisternia J. Gardner, 1944 (TS $\uparrow$ Hesperisternia waltonia J. Gardner, 1944; OD) ${ }^{(1)}$

Pisania Bivona-Bernardi, 1832 (TS Pisania striatula Bivona-Bernardi, 1832 [= Pisania striata (Gmelin, 1791)]; SD, Opinion 740 (1965)) ${ }^{(1)}$

Pollia Gray, 1834 (TS Buccinum undosum Linnaeus, 1758; M) ${ }^{(1)}$ 


\section{Sinetectula Fraussen \& Vermeij, 2021 (TS Buccinum (Pollia) farinosum Gould, 1850; OD) ${ }^{(1)}$}

2

Diagnosis. Shell medium-sized to medium large, exceptionally reaching $100 \mathrm{~mm}$ (Cantharus), from fusiform to broadly fusiform or biconic, with low to medium-high spire and short to nearly obsolete siphonal canal. Protoconch small, paucispiral or multispiral, comprising 1.5 to more than 3.5 whorls. Whorl outline flattened, weakly or strongly convex. Axial sculpture of strong and closely spaced ribs, rarely absent (Pisania). Spiral sculpture ranging from fine striation to distinct prominent cords, sometimes keels forming nodules at intersection with axial ribs. Aperture high, outer lip typically thickened, striated or denticulated inwards. Inner lip often heavily calloused, often with distinct anal denticle or knob, sometimes bearing multiple denticles or lirae. Shell sometimes covered with very thick hirsute periostracum. Operculum spanning entire aperture, assymetrical, drop-shaped, thick, with terminal nucleus.

Radula (Fig. 22) central tooth with relatively narrow, rectangular or trapeziform base, bearing 5 cusps, outer pair very weak, sometimes obsolete (Fig. 20B). Lateral teeth with 2, 3 (usually) or 4 cusps, intermediate cusps always smaller, sometimes inner cusp longer (Fig. 20B, C), but usually shorter than outer cusp; inner cusp sometimes with serrated inner edge. Proboscis medium to long; large, paired proboscis retractors emerging laterally from posterior part of rhynchodaeum, numerous additional lateral bundles of retractors can be present at mid-length of rhynchodaeum. Odontophore with radula long, spanning entire proboscis length, and can protrude backwards from proboscis. Valve of Leiblein from small to well defined, pear-shaped, gland of Leiblein small and flaccid to large, folded anteriorly. Salivary glands medium-large to large, not fused. Stomach long, with very short posterior mixing area. The anatomical account is based on studies of Gemophos tinctus (Conrad, 1846) (Kosyan \& Kantor, 2004), Pollia undosa (Linnaeus, 1758), P. fumosa (Dillwyn, 1817), and Ecmanis fasciculatus (Reeve, 1846) (herein).

Distribution. Tropical and temperate northern Atlantic, Indo-Pacific, temperate northern Pacific and temperate Australasia, at intertidal to subtidal depths.

Remarks. The Pisaniidae are a large group of mainly tropical Buccinoidea that exhibit a significant range of conchological and morphological (radula) forms. The Pisaniidae were generally recognized as a subfamily of Buccinidae (e.g. Cernohorsky, 1971; Watters \& Finlay, 1989; Vermeij, 2001; Bouchet \& Rocroi, 2005; Fraussen \& Stahlschmidt, 2016), but was ranked as a full family, distinct from Buccinidae by Bouchet et al. (2017), based on the molecular tree of Galindo et al. (2016). This is confirmed by our molecular phylogeny.

Eight of the genera traditionally included in the family were represented in our multigene analysis. The genus level taxonomy was reviewed by Vermeij (2001) and is mostly followed here, with the exception of several genera transferred to Prodotiidae. In total 15 valid genera are attributed to the family (see also Table 3).

The family is in need of a revision based on molecular data, since our data reveal the polyphyly of at least Pisania and Engina; furthermore, some of the genera currently assigned to the family may belong to Prodotiidae. Three species of "Pisania" were included in our multigene analyses, two of them ["Pisania" decollata (G. B. Sowerby I, 1833) and "P." ignea (Gmelin, 1791)] cluster together with maximal support, while " $P$." pusio (Linnaeus, 1758) forms a separate branch. In the analysis of extended coxl dataset, P. striata (Gmelin, 1791), the type species of the genus, did not cluster with any of these other three species. A revision of Pisania is beyond the scope of the present study and requires a much more extensive dataset. We can nevertheless state that the name Pisania cannot be applied to any of the species included into our 
multigene analyses. Instead, Ecmanis Gistel, 1848 [nom. nov. pro Proboscidea Möller, 1832, non Bruguière, 1791; type species Buccinum igneum Gmelin, 1791] is applicable to the clade uniting "P." decollata and "P." ignea. Based on the characteristic spiral sculpture of broadly spaced strong keels in P. decollata (Fig. 21H), Dall (1904) proposed the subgenus Taeniola [invalid, non Taeniola Pallas, 1760 [Cestoda] = Taenia Linnaeus, 1758]. Furthermore, the radula of " $P$. " decollata (Fig. 22B) is rather similar to the radula of " $P$." fasciculata (Reeve, 1846) $[=P$. montrouzieri Crosse, 1862] (Fig. 22C), the type species of Appisania Thiele, 1929, a name that may be applicable to " $P$." decollata.

Four species of "Engina" (in the currently accepted scope) were included in our multigene analysis. Three of them - the type species Engina turbinella, E. mendicaria and E. alveolataform a highly supported clade that includes both western Atlantic and Indo-West Pacific species. Their radulae are very different from each other (Fig. 22E, F; Cernohorsky, 1971: fig. 65 for $E$. alveolata), thus suggesting its low taxonomic value. Previously accepted as an Engina, Sinetectula egregia (Reeve, 1844) forms an independent long branch, recovered in our tree in a position sister to all other Pisaniidae. "Engina" corinnae (Fig. 21E) despite being conchologically similar to Engina s.s. also shows no immediate relationship to it, and should also be excluded from the genus.

\section{FAMILY NASSARIIDAE IREDALE, 1916 (1835)}

(Figs 23, 24)

Type genus: Nassarius Duméril, 1805

SUBFAMILY NASSARIINAE IREDALE, 1916 (1835)

= Nassinae Swainson, 1835. Type genus Nassa Lamarck, 1799. Invalid: type genus a junior homonym of Nassa Röding, 1798 [Gastropoda]

$=$ Cyclopsidae Chenu, 1859. Type genus Cyclops Montfort, 1810. Invalid: type genus a junior homonym of Cyclops O. F. Müller, 1776 [Crustacea]

$=$ Cyclonassinae Gill, 1871. Type genus: Cyclonassa Swainson, 1840

$=$ Alectrionidae Dall, 1908. Type genus: Alectrion Montfort, 1810

$=$ Arculariidae Iredale, 1915. Type genus: Arcularia Link, 1807]

Included genera:

Caesia H. Adams \& A. Adams, 1853 (TS Nassa perpinguis Hinds, 1844; SD ,Wenz, 1943) (3)

Demoulia Gray, 1838 (TS Buccinum retusum Lamarck, 1822; SD, Herrmannsen, 1847) ${ }^{(3)}$

Nassarius Duméril, 1805 (TS Buccinum arcularia Linnaeus, 1758; by subsequent monotypy, Froriep, 1806). Synonyms: Alectrion Montfort, 1810 (TS Buccinum papillosum Linnaeus, 1758; OD); Arcularia Link, 1807 (TS Buccinum gibbosulum Linnaeus, 1758; SD, Cossmann, 1901b: 215)(1)

Nassodonta H. Adams, 1867 (TS Nassodonta insignis H. Adams, 1867; M) ${ }^{(1)}$

Naytia H. Adams and A. Adams, 1853 (TS Strombus glabratus G.B. Sowerby II, 1842; SD, Cossmann, 1901) ${ }^{(1)}$

Phrontis H. Adams and A. Adams, 1853 (TS Buccinum tiarula Kiener, 1841; SD, Cossmann, 1901) (1) 


\section{Reticunassa Iredale, 1936 (TS Nassa paupera Gould, 1850; OD) ${ }^{(1)}$}

Tritia Risso, 1826 (TS Buccinum reticulatum Linnaeus, 1758; SD, Gray, 1847). Synonyms: Nassa Lamarck, 1799 (non Röding, 1798) (TS Buccinum mutabile Linnaeus, 1758; M); Cyclops Montfort, 1810 (non O. F. Müller, 1776) (TS Cyclops asterizans Montfort, 1810; OD); Cyclonassa Swainson, 1840 (TS Buccinum neriteum Linnaeus, 1758; M) ${ }^{(1)}$

Diagnosis. Shell from small to medium-large, very variable in shape, normally bucciniform, but from fusiform to broadly fusiform and oval, and occasionally (e.g. Tritia neritea (Linnaeus, 1758)) discoidal with nearly flat spire, without siphonal canal and with distinct siphonal notch. Spire from very short to high. Parietal callus can be hypertrophied to form a glossy shield, covering entire ventral side of the shell. Protoconch paucispiral or multispiral, development planktotrophic, lecithotrophic, or ovoviviparous. Axial sculpture usually present, of variously developed ribs at least on adapical teleoconch whorls, and sometimes forming distinct knobs at intersection with spiral cords, but can be completely absent (Nassodonta). Spiral sculpture from well developed to nearly obsolete. In Nassodonta distinct spiral sulcus at shell base. Aperture with smooth or lirate outer lip, inner lip can bear a parietal knob. Operculum with a terminal nucleus, with simple or serrated edges; in Nassodonta with two spines.

Radula (Fig. 24E) central tooth broadly arcuated, with numerous even-sized cusps. Lateral teeth in most representatives bicuspid, but irregularly multicuspid in Hebra H. Adams \& A. Adams, 1853 (considered a synonym of Nassarius by Galindo et al., 2016) (Cernohorsky, 1984: figs 43-45). At the inner corner of the lateral teeth a cuspless, irregular, intermediate lateral accessory plate is present in some species (Cernohorsky, 1984: figs 27, 28). Proboscis long, not coiled within rhynchocoel, valve of Leiblein distinct, gland of Leiblein tubular, medium-large. Salivary glands small, not fused. In some species, stomach with a crystalline style (e.g., Tritia obsoleta (Say, 1822); see Brown, 1969). Foot with paired metapodial tentacles.

Distribution. Cosmopolitan, except Arctic and Southern Ocean, from intertidal to about 2,000 m (Cernohorsky, 1984).

Remarks. Galindo et al. (2016) revised the classification of the Nassariidae based on five molecular markers obtained for 218 nassariid species. Several genera formerly included in the Buccinidae (Antillophos, Engoniophos, Phos, Nassaria, Tomlinia and Anentome) were included in the analysis and found to belong in Nassariidae. Nassariidae were recovered monophyletic. In the resulting classification, Galindo et al. (2016) recognized seven subfamilies of Nassariidae, including the new subfamily Buccinanopsinae. In our analysis, Nassariidae sensu Galindo is paraphyletic: Buccinanopsidae are clustering with Macron and Busyconidae, while Columbellidae are nested within Nassariidae s.l. as sister to Cylleninae. There are also a number of other differences with Galindo's tree, such as Dorsanum then nested within Nassariinae and now constituting its own subfamily Dorsaninae.

Due to a dataset of Nassariidae s.l. herein much more limited in comparison with that of Galindo et al. (2016), we overall follow their system with the exception of Buccinanopsidae being segregated and the erection of the new subfamily Tomliniinae.

\section{SUBFAMiLy BULLIINAE ALLMON, 1990}

Type genus: Bullia Gray, 1833 
Included genera:

Bullia Gray, 1833 (TS Bullia semiplicata Gray, 1833; M) ${ }^{(1)}$

Diagnosis. Shell from medium-sized to medium-large, variable in shape, from fusiform to narrow fusiform, normally bucciniform, without siphonal canal and with distinct siphonal notch, usually glossy. Spire from high to very high. Parietal callus can be strongly thickened and forming an oblique ridge overlaying the suture. Protoconch smooth, large, of about 3 whorls. Development direct with nurse eggs, or ovoviviparous. Axial sculpture absent or limited to short subsutural ribs. Spiral sculpture either absent, or of spiral, broadly spaced grooves, rarely of raised cords. Aperture smooth inside. Operculum often very small, with a terminal nucleus, with simple or serrated edges.

Radula central tooth broadly arcuated, with very numerous (up to 20) cusps gradually diminishing towards the edge of tooth; lateral teeth with 4 or 5 cusps, outer one largest and intermediate much smaller. Proboscis short and broad, valve and gland of Leiblein absent. Stomach with medium-long posterior mixing area (anatomy based on description of Bullia laevissima (Gmelin, 1791); Abbate \& Simone, 2016). Foot with paired metapodial tentacles. Eyes absent.

Distribution. South Africa and western Indian Ocean, intertidal and shallow subtidal.

\section{SUBFAMILY ANENTOMINAE STRONG, GALINDO \& KANTOR, 2017}

Type genus: Anentome Cossmann, 1901

Included genera:

Anentome Cossmann, 1901 (TS Melania helena von dem Busch, 1847; by typification of replaced name (Canidia $\mathrm{H}$. Adams, 1862 non J. Thomson, 1857 [Coleoptera])) ${ }^{(1)}$ Clea H. Adams \& A. Adams, 1855 (TS Clea nigricans A. Adams, 1855; M) ${ }^{(1)}$ Oligohalinophila Neiber \& Glaubrecht, 2019 (TS Canidia dorri Wattebled, 1886, OD) ${ }^{(1)}$

Diagnosis. Shell medium-sized, variable in shape, from nearly oval to fusiform, without siphonal canal and with distinct siphonal notch. Spire from medium-high to high. Axial sculpture usually present, of distinct sigmoidal ribs, absent in Clea. Spiral sculpture of distinct, albeit low, cords, present at least on shell base, often on entire shell surface. Aperture smooth inside. Operculum large, with terminal nucleus, with simple edges, in Anentome with thickened, pointed, elevated process behind nucleus.

Radula (Fig. 24C, D) variable, either with arcuated central tooth with 5-7 medium-sized or small cusps (Clea, Anentome) and tricuspid lateral teeth, outer cusp largest; or with central tooth with about 10 cusps (Oligohalinophila, Fig. 24D) and multicuspid lateral teeth with 6 or 7 cusps, innermost serrated along inner edge. Proboscis medium to long, numerous proboscis retractors forming bundles attached laterally to mid-rhynchodaeum, in Anentome with very large additional paired retractors at base of rhynchodaeum. Valve of Leiblein distinct, gland of Leiblein absent. Stomach with very long posterior mixing area and closely spaced ducts of digestive gland (anatomy after Strong et al., 2017). Foot metapodial tentacles absent.

Distribution: Fresh and low salinity waters in South and South-East Asia. 
SUBFAMILY DORSANINAE COSSMANN, 1901

Type genus: Dorsanum Gray, 1847

[= Duplicatinae Muskhelishvili, 1967. Type genus: Duplicata Korobokov, 1955]

Included genus:

Dorsanum Gray, 1847 (TS Buccinum politum Lamarck, 1822 [= Dorsanum miran (Bruguière, 1789)]; OD). Synonym: Duplicata Korobkov, 1955 (TS Buccinum duplicatum J. de C. Sowerby, $1832 ; \mathrm{OD})^{(1)}$

Diagnosis. Shell medium-sized, elongate-fusiform, without siphonal canal and with distinct siphonal notch. Spire high. Protoconch elongated, smooth, shining, of ca 2 whorls. Axial sculpture present on adapical spire whorls, vanishing on last whorls, of broad folds, rounded on top, spiral sculpture absent. Aperture weakly lirate inside. Operculum small, oval, with simple edge and subcentral nucleus shifted to low edge of operculum.

Radula with broad arcuated central tooth with numerous (15-20) small cusps, and bicuspid lateral teeth. Proboscis long, not coiled within rhynchocoel, valve of Leiblein small, distinct, gland of Leiblein tubular, medium large. Salivary glands small, not fused. Stomach with long posterior mixing area and three closely spaced ducts to digestive gland (anatomy after Simone \& Pastorino, 2014). Foot with short paired metapodial tentacles.

Distribution. West Africa, subtidal.

Remarks. Dorsanum miran (Bruguière, 1789) is the only known Recent species.

SuBfAMiLy PHOTINAE GRAY, 1857

Type genus: Phos Montfort, 1810.

Included genera:

Antillophos Woodring, 1928 (TS Cancellaria candeana d'Orbigny, 1842; OD) ${ }^{(1)}$

Engoniophos Woodring, 1928 (TS † Phos erectus Guppy, 1873; OD) ${ }^{(1)}$

Northia Gray, 1847 (TS Buccinum pristis Deshayes, 1844; OD) ${ }^{(1)}$

Phos Montfort, 1810 (TS Murex senticosus Linnaeus, 1758; OD) ${ }^{(1)}$

Diagnosis. Shell medium-large, reaching $80 \mathrm{~mm}$ (Northia), fusiform, with medium-high spire and nearly obsolete siphonal canal with distinct siphonal notch. Some species with periodical varices. Protoconch small, from paucispiral to multispiral with carinae. Axial sculpture of strong and closely spaced, sometimes sharp, ribs, in Northia present on adapical spire whorls; spiral sculpture of distinct prominent cords, sometimes forming nodules at intersection with axial ribs. In Northia spiral cords present only on adapical spire whorls and shell base. Aperture high, lirate inside. Operculum spanning most or all of aperture, lanceolate, with terminal nucleus.

Radula (Fig. 24F-H) central tooth of two types: tricuspid with arcuated basal plate (Phos, Northia) (Fig. 24F, G), or very broad, multicuspid (Engoniophos) (Fig. 24H); lateral teeth bicuspid, outer cusp longest. Anatomy studied in Engoniophos unicinctus (Say, 1826) (Abbate et al., 2018), several species of Phos and Northia pristis (this paper). Metapodium with or without 
single tentacle. Head tentacles long with eyes situated at mid-length on poorly defined lobes. Proboscis long, usually not coiled within rhynchocoel, partially coiled in Northia. Proboscis retractors lateral, either a single pair or several on each side, detached from rhynchodaeum at mid-length. Valve of Leiblein distinct, gland of Leiblein tubular, not large, with long constricted duct. Salivary glands small, fused (Phos), or separate (Engoniophos, Northia), salivary ducts very thin. Stomach (Phos, Northia) very small, broadly U-shaped with very small posterior mixing area.

Distribuion. Tropical Atlantic and Indo Pacific, subtidal.

Remarks. Galindo et al. (2016) first included the subfamily Photinae (previously included in Buccinidae) in Nassariidae, as the second offshoot of the family in their tree, but the corresponding node was not supported. In our tree, the subfamily is sister to the rest of the Nassaridae + Columbellidae.

\section{SUBFAMILY TOMLINIINAE SUBFAM. NOV.}

Type genus: Tomlinia Peile, 1937

Included genera:

Nassaria Link, 1807 (TS Nassaria lyrata Link, 1807 [= Nassaria pusilla (Röding, 1798)]; SD, Eames, 1952) (1)

Tomlinia Peile, 1937 (TS Buccinum rapulum Reeve, 1846; OD) ${ }^{(1)}$

? Trajana J. Gardner, 1948 (TS †Trajana pyta J. Gardner, 1948; OD)(3)

Diagnosis. Shell medium-large, reaching $50 \mathrm{~mm}$, fusiform to broad-fusiform or nearly oval, with medium to high spire and from obsolete to short siphonal canal, with distinct siphonal notch, siphonal canal can be closed (Trajana). Protoconch small, paucispiral, off 1.5-3 whorls. Axial sculpture of strong and closely spaced, sometimes sharp, ribs, absent in Tomlinia. In addition to ribs periodical varices can be present. Spiral sculpture normally distinct on entire shell, but only on shell base in Tomlinia. Aperture medium to high, from narrow to broad. Outer lip lirate in Nassaria and Trajana, smooth in Tomlinia. Columella smooth or with low denticles. Operculum oval, with terminal nucleus, sometimes with serrated edge.

Radula (Fig. 24A, B) central tooth multicuspid, with rectangular base in Nassaria and narrow, arcuate in Tomlinia; in the latter additional, much smaller, cusplets between larger cusps; lateral teeth bicuspid, outer cusp longest.

Distribution. Estuarine areas in Vietnam, Malaysia and Indonesia (Tomlinia), entire tropical Indo-Pacific, temperate eastern Pacific, subtidally to bathyal depths (Nassaria and Trajana; Cernohorsky, 1981).

Remarks. This subfamily unites rather heterogeneous genera. While Nassaria lives subtidally to over $900 \mathrm{~m}$ throughout the Indo-Pacific, Tomlinia is one of a few genera of Buccinoidea that penetrates estuarine and fresh waters in South East Asia. Nassaria and Trajana on one hand, and Tomlinia on the other, are conchologically markedly different. This clade with high support in our analysis was also recovered by Galindo et al. (2016) (albeit without support) as sister to Cyllene and included by them in the subfamily Cylleninae. In our analysis it is recovered, albeit without support, as a sister to the clade (Cyllene (Columbellidae)). We have 
1 chosen to form the name of the subfamily based on the genus Tomlinia to avoid the confusion of 2 having two family group names based on the genera Nassarius and Nassaria.

\section{SUBFAMILy CYLLENINAE BELLARDI, 1882}

Type genus: Cyllene Gray, 1834

Included genera:

Cyllene Gray, 1834 (TS Cyllene owenii Gray, 1834; M) ${ }^{(1)}$

Neoteron Pilsbry \& Lowe, 1932 (TS Hindsia ariel Pilsbry \& Lowe, 1932; M) ${ }^{(2)}$; radula, see D’Attilio (1981)

Diagnosis. Shell medium-sized, reaching $20 \mathrm{~mm}$, bucciniform, with low spire, without siphonal canal, and with distinct siphonal notch. Suture grooved. Protoconch small, paucispiral or multispiral, smooth. Axial sculpture of variously developed ribs, sometimes sigmoidal, on last whorl may be present adapically only. Spiral sculpture of distinct prominent cords, present on spiral whorls and at least in adapical part of last whorl and shell base. Aperture elongate and narrow, outer lip thick, interior prominently lirate; columella calloused and distinctly plicate. Operculum brown, elongated and pointed, margins even, with terminal nucleus.

Radula (Fig. 24I) central tooth broad, with arcuated base, multicuspid, with up to 20 cusps, gradually diminishing in length from center to sides; lateral teeth with narrow and thickened base, outer cusp long, inner cusp absent or very reduced to a mere subtriangular protrusion.

Distribution. West Africa, tropical Indo-West Pacific and S.E. Australia (Cernohorsky, 1984).

Remarks. The taxonomic position of the enigmatic genus Neoteron is problematic. Conchologically the shell is more similar to Muricidae than to any Buccinoidea (Fig. 23C). Galindo et al. (2016: 350) included it in Photinae based on the "reconstruction of ancestral characters", probably protoconch morphology. The radula was examined by D'Attilio (1981) and although the drawing (reproduced herein on Fig. 24I, lower panel, with some alteration in the position of the lateral tooth) was not supplemented by any description, it is in most details similar to the characteristic radula of Cyllene (Fig. 24I, upper panel) and Neoteron is thus transferred herein to Cyllenidae.

FAMILY COLUMBELLIDAE SWAINSON, 1840

= Anachidae Golikov \& Starobogatov, 1972. Type genus:Anachis H. Adams \& A. Adams, 1853

= Pyrenidae Suter, 1909. Type genus: Pyrene Röding, 1798 (TS Pyrene rhombiferum Röding, 1798; M)]

SUBFAMILY COLUMBELLINAE SWAINSON, 1840

Type genus: Columbella Lamarck, 1799 (TS Voluta mercatoria Linnaeus, 1758; M)

SUBFAMiLY ATILIINAE COSSMANN, 1901 
Type genus: Atilia H. Adams \& A. Adams, 1853 (TS Columbella suffusa G. B. Sowerby I, 1844; SD, Pace, 1902). Synonym: Anachis H. Adams \& A. Adams, 1853. Type genus:Anachis H. Adams \& A. Adams, 1853 (TS Columbella scalarina G.B. Sowerby I, 1832; SD, Tate, 1868)

Remarks. Columbellidae is a very speciose family, currently including 76 valid genera and 911 Recent species (MolluscaBase, accessed 20.12.2020) and represented in our analysis by only seven species in six genera. It is recovered monophyletic with maximal support and sister to Cylleninae of Nassariidae (without support). Columbellidae possess a radula unique for Buccinoidea, with a rectangular acuspate central tooth and lateral teeth with very narrow base and 3-5 cusps along the inner edge (see, e.g. Bandel, 1984). In Pseudanachis basedowi (Hedley, 1918) (not included in the analysis) the radula is markedly different in having multicuspidate central teeth and nearly subtriangular lateral teeth with more than 10 small cusps (Guralnick \& deMaitenon, 1997).

\section{UNNASSIGNED BUCCINOIDEA}

Macron H. Adams \& A. Adams, 1853 (TS Buccinum aethiops Reeve, 1847; M)

Remarks. The position of Macron has been debated for a rather long time. It was initially described as a subgenus of Pseudoliva Swainson, 1840, and remained included in Pseudolividae until Thiele (1929) illustrated the typically buccinoidean radula of M. lividus (A.Adams, 1855) and M. aethiops (Reeve, 1847) [as M. trochlea (Gray, 1839)] (herein, Fig. 16J) and transferred it to the Buccinidae. The placement proposed by Thiele was followed by some authors (e.g. by Wenz, 1938-1944 and Keen, 1971), but later Vermeij (1998) re-assigned Macron to Pseudolividae on conchological grounds despite acknowledging the buccinoidean radular morphology. Kantor et al. (2017) removed the genus from Pseudolividae and, after Landau et al. (2013), suggested affinities to the Nassariidae. The present results clearly indicate that Macron is a genus of Buccinoidea, as it is recovered in a highly supported grouping with Buccinanopsidae. However, in shell and radular characters, Macron lividus is very different from Buccinanops and we do not include Macron in Buccinanopsidae. The affinities of the southern African genus Burnupena Iredale, 1918 (TS Buccinum porcatum Gmelin, 1791 [= Burnupena cincta (Röding, 1798)]; OD; see Orr, 1956) are also uncertain, and the genus shows rather strong similarities to Macron in shell and radular morphology. It is possible that future studies will confirm the relationships between the two genera and a new taxon of the family group will be established.

\section{MORPHOLOGY AND ITS TAXONOMIC VALUE}

The soft body morphology of the Buccinoidea studied herein is rather uniform. Some families are characterized by specific characters, e.g. the very long and tubular head of Melongenidae, or the presence of metapodial tentacle(s) in Nassariidae. In general, it is difficult to recognize a priori the structures that bear a strong phylogenetic signal. For example, opercula are rather morphologically heterogeneous. In most groups they have a terminal nucleus, but in some a concentric operculum with subcentral nucleus (so far found only in the subfamily 
Buccininae) or a paucispiral one are present, the latter found in several unrelated groups (some Dolicholatiridae, some Cominellidae, some Siphonaliinae, Retimohniidae, and some Prosiphonidae). Nevertheless, within Buccinidae the opercular morphology seems to be a reliable diagnostic character for subfamily level taxa: in Beringiinae, the operculum closes entirely the aperture with a terminal nucleus strongly shifted adaxially; in Buccininae, the operculum is concentric, while in Volutopsiinae the operculum, with a nucleus strongly shifted adaxially, is very small in comparison to the large aperture; in Neptuneinae, the operculum is large, closing nearly entirely the aperture, drop-shaped, with terminal nucleus shifted adaxially.

The digestive tract is also rather uniform with regard to its main components: anterior foregut, containing proboscis, salivary glands, valve and gland of Leiblen, and mid-gut (stomach). Accessory salivary glands are absent in all Buccinoidea. The proboscis is long to very long, the valve of Leiblein is usually present (absent in some Colubrariidae, all Melongenidae, and in the buccinid subfamily Volutopsiinae). The presence of the gland of Leiblein is usually correlated with the presence of the valve of Leiblein, although the gland can be absent even when the valve is still recognizable, although very reduced (some Colubrariidae, Neptuneinae of Buccinidae, Anentominae of Nassariidae). The salivary glands are paired (and can be fused), acinous, and the salivary ducts usually follow freely along the oesophagus, but they can enter the walls of the oesophagus shortly after leaving the glands (Belomitridae, Colubrariidae, Tudiclidae). Beyond these shared traits, some families have a very distinctive digestive system, e.g. Colubrariidae with an extremely long and thin proboscis coiled withing the rhynchodaeum, an extended mid-oesophagus without traces of gland and valve of Leiblein, and, finally, a uniquely shaped stomach in which the intestine is opening posterior to the oesophagus.

Stomach morphology is potentially important in phylogenetic inference, although it remains poorly studied. A single comparative study of the stomach anatomy of different Buccinoidea was made by Kantor (2003), and there are numerous descriptions of different representatives in the literature. Important characters are the presence and size of the posterior mixing area defining the general outline of the stomach, the position and number of ducts of the digestive gland, or the presence of a gastric shield. When available, brief descriptions of the stomach are provided above in the diagnoses of the family group taxa.

The radula is one of the best studied morphological characters in Buccinoidea and, compared to other morphological structures, is least dependent of preservation conditions, and it was often used for taxonomic decisions. The radula of Buccinoidea usually consists of three teeth per transverse row, rarely the central tooth is reduced or even absent (some Prosiphonidae). Conversely, in the Nassariinae there is an additional cuspless intermediate lateral accessory plate between the central and lateral teeth. The function and homology of these plates are unknown.

In the most common radula type of Buccinoidea, found in many unrelated lineages, the central tooth with a rectangular base bears 3-6 cusps, and the lateral teeth are moderately multicuspid (3-6 cusps), with the outer cusp longest. Such radulae are recorded in Austrosiphonidae, Buccinidae (Buccininae, Neptuneinae, some Parancistrolepidinae), Busyconidae, Retimohniidae, some Nassariidae, Prodotiidae and some Prosiphonidae (e.g. Neobuccinum and Chlanidota). A very peculiar shape of the lateral teeth is found in some genera of Prosiphonidae and in the unrelated Chauvetiidae; there, the outer portion of the basal plate is long, narrow and attenuated, forming a "handle" (Figs 9F-I, 20B). In many cases the rows of teeth are strongly overlapping and this attenuated portion is seen only in oblique view. The number of cusps on the lateral teeth is not correlated with the presence of the handle, nor is the 
1 central tooth morphology. The latter can be well developed, with squarish base and well 2 developed cusp(s) (e.g. some Prosipho, see Numanami, 1996; Argeneuthria, Fig. 9G, H herein, 3 both Prosiphonidae; or Chauvetia, Fig. 20B, Chauvetiidae), or it can be very reduced to rather a 4 single obtuse cusp (e.g. Antistreptus, Prosiphonidae, Fig. 9I), or it can altogether be absent 5 (Meteuthria martensi (Strebel, 1905), Pastorino, 2016).

Few of the family group taxa are characterized by a unique radula type. In Tudiclidae the radula is very uniform (Fig. 17F-P) throughout all genera and possesses a very characteristic central tooth with trapeziform basal plate, narrowing towards the posterior edge, with three cusps that occupy the width of the entire basal plate. Columbellids possess a more variable although still similar radulae, with an acuspate central tooth rectangular plate and laterals characterized by a very narrow, constricted base attached to the membrane, so that tooth length exceeds several times the width of the base, while normally 3-5 distinct cusps emanate from the inner edge of the tooth. Superficially similar acuspate central teeth are found in the unrelated subfamily Beringiinae (Buccinidae) (Fig. $11 \mathrm{C}$ ).

Other families characterized by a unique morphology of lateral radular teeth are the Dolicholatiridae and Belomitridae (Fig. 4), with long and narrow teeth base with the cusps shifted close to the tips. All species of Melongenidae studied so far are characterized by bicuspid lateral teeth (Fig. 20A), although similar teeth are found in the unrelated Volutopsiinae (Buccinidae), Eosiphonidae and some other buccinoidean lineages. Special attention should be paid to the radula of Pisaniidae. While the lateral teeth are rather variable in shape, the number of cusps (2-4) and the presence or absence of serration on the inner side of the inner cusp and the central teeth are markedly uniform. In all species studied in this respect (except Cancellopolia ustulata Vermeij \& Bouchet, 1998, see Vermeij \& Bouchet, 1998) the central tooth is rectangular, with three major cusps on the posterior edge abated by distinct much smaller cusps on each side (Fig. 22 herein; Cernohorsky, 1971: figs 17-20, 23, 28; Ponder, 1972: figs 1-5, 912). These additional cusps can be reduced together with the major cusps (as in "Engina" egregia). On the contrary, in Prodotiidae (which encompass genera previously classified in Pisaniidae) these lateral secondary cusps are absent (Fig. 20C-F herein; Cernohorsky, 1971: fig. 27; Ponder, 1972: figs 6, 7, 13). After further studies, this may appear to be a reliable morphological character distinguishing the two families. Also this is questioning the generic assignment of Cancellopolia ustulata that may belong to a new genus of Prodotiidae.

Opposite examples are also numerous. The family Prosiphonidae exhibits the most diverse array of radulae of any buccinoideans (Fig. 9). Our tree includes sequenced representatives possessing at least three different radula types, which Powell (1951) thought were characterizing families/subfamilies. Our data however demonstrate that radula morphology of Prosiphonidae is not correlated with the evolutionary history of the group. Likewise, in Buccinidae the disparity of radula morphology is high, with some subfamilies characterized by a rather specific morphology - e.g. Beringiinae with strongly modified lateral teeth and acuspate central teeth (Fig. 11C) and Volutopsiinae with always bicuspid lateral teeth (Fig. 11H) (Kantor, 1990). Nassariidae also exhibit a high disparity of radular morphology (Fig. 24) with multicupid vs tricuspid central tooth found in the same subfamily Photinae (Fig. 24F-H).

Summing up, we conclude that with the exception of some families, the rather uniform radular morphology alone does not allow the allocation of genera to a particular family without additional molecular data. The radula nevertheless remains a valuable taxonomic character in some groups in combination with the morphology of the digestive tract. 
Buccinoidea contribute prominently to the molluscan faunas of high latitudes, and it is interesting to comments on the biogeographic patterns emerging from the reconstructed phylogeny of the superfamily. First, we observe a clear latitudinal pattern, with no bipolar families as circumscribed herein, neither shared between any of the poles and the tropics.

The routes of colonization of the Arctic and the connections between the Arctic fauna and adjacent oceans have been previously discussed (e.g., Durham \& MacNeil, 1967; Vermeij, 1991; Vermeij et al., 2019). It is well established that throughout the Cenozoic, the Arctic fauna was mainly influenced by migrations from the Atlantic, and the shelf fauna of the Arctic Ocean was repeatedly extirpated during glaciations (Hardy et al., 2010). Then, starting 3.5 MYA, when Bering Strait opened, not only the Northern Pacific fauna poured into the Arctic Ocean, but also faunal exchange became possible via cross-Arctic invasion of the Atlantic by Pacific taxa, and vice versa. The analysis of recent faunas suggests that expansion of originally Pacific taxa to the Atlantic was notably more frequent than the cross-Arctic invasion of the Pacific by Atlantic taxa (Vermeij, 1991).

Two buccinoidean families reach the Arctic: Colidae and Buccinidae, the latter represented in the Arctic by members of four subfamilies: Buccininae, Neptuneinae, Beringiinae and Volutopsiinae. Colidae is represented in our dataset by eight species from the genera Colus and Turrisipho, all collected off Iceland or off the Russian coast of the Barents Sea. Kosyan (2007) mentions three species of Colus that occur in the North-West Pacific: Colus islandicus, C. minor (Dall, 1925), and C. kujianus Tiba, 1973. One more species, Colus bukini Kantor, 1984 was described fron the southern Kuril Islands. Unfortunately, none of the latter species, which are restricted to the Pacific, was available to test the monophyly of Colus, bus as there are no data, to our knowledge, to doubt it, we provisionally accept it as monophyletic. Based on the examination of Miocene and Pliocene fossil material, Vermeij (1991) concluded that Colus is a genus that originated in the Atlantic, which implies that C. minor and C. kijianus are the result of a cross-Arctic invasion.

The situation is opposite in the Buccinidae. Among the 37 species of Buccinidae (as redefined herein) included in the multigene and extended $\mathrm{COI}$ analyses, 28 were sampled in the North Pacific and nine (three Buccinum, two Neptunea, two Beringius, one Anomalisipho, and one Mohnia) in the North Atlantic or the European sector of the Arctic Ocean. The highest diversity of the living Buccinidae is recorded in the temperate North Pacific (Golikov, 1963, 1980; Kantor, 1990; Okutani, 2017), and the buccinid fossil record in the Pacific can be traced back to the Eocene (Gladenkov et al., 1988; Vermeij et al., 2019). It is clear that the family Buccinidae is a lineage originating from the Pacific that has invaded the Atlantic only after the opening of Bering Strait. In conclusion, our results suggest that originally there has been two unrelated buccinoidean radiations at high latitudes in the Northern Hemisphere, one per ocean.

Clarke and Crame (1989: 264) suggested that the Antarctic has continuously been an arena of molluscan faunal evolution: "Overall the fauna has had a long evolutionary history and thus has no single origin. In a sense, it has always been there". Beu (2009) stressed that an Antarctic molluscan fauna similar to the recent one was well established by early Cenozoic times, and the Buccinoidea were a prominent element thereof: 'The most diverse families of Antarctic larger gastropods have remained largely unchanged since Paleocene and Eocene time: Trochidae, 
1 Naticidae, Conoidea and, above all, Buccinoidea (sensu lato)'. However, as suggested by Beu (2009), composition of buccinid fauna of Antarctica as per early Eocene was a result of an earlier faunal change. In this change, in particular, larger forms referred by Beu to Busyconidae and Melongenidae (Beu, 2009), which were worldwide distributed in Mesozoic and Paleocene gradually decline in abundance. Previous studies by Vaux and co-authors $(2017,2018)$ and our present results identify at least three lineages of Buccinoidea that have independently originated in or colonized the Antarctic: the Prosiphonidae, Cominellidae and Austrosiphonidae.

The Prosiphonidae comprise mainly Antarctic taxa, with some members in Magellanic and temperate Australian faunas. The latter are represented in our dataset by Antarctodomus cf. powelli from off Tasmania, and Austrofusus glans from New Zealand. Dates of the family diversification are to be determined, but Beu (2009) remarked that at least three genera, Prosipho, Probuccinum and Chlanidota, were already diversified in Antarctica by the Eocene. The distribution of the recent family members reflects close connections between Antarctica, Australia and New Zealand throughout the early Cenozoic, and is consistent with an origin of Prosiphonidae on a Southern Ocean shelf of breaking up Gondwana.

Cominellidae are represented in our dataset by Pareuthria turriformis from the Antarctic and P. fuscata from Patagonia, whereas most species of Cominella inhabit the temperate Australia-New Zealand region (Donald et al., 2015). Vaux et al. dated the diversification of the Cominella crown group at $\sim 55$ MYA, and Beu (2009) mentioned that Pareuthria (representing another subclade of Cominellidae in our tree) was among the genera present in the Antarctic fauna by the Eocene. This suggests that Cominellidae as circumscribed herein originated in the Cretaceous-Paleocene, and the distribution of recent members of the family, as in Prosiphonidae, does not reject an origin on continental shelves and slopes bordering the Southern Ocean.

The family Austrosiphonidae is mainly represented by Australia-New Zealand taxa but, based on the analysis of Vaux et. al (2018), it includes the Antarctic Antarctoneptunea aurora and, based on our data, also Seratifusus lineatus from Norfolk Ridge off New Caledonia. The evolutionary history of this group is discussed in detail by Vaux et al. (2017), and the inferred origin of its temperate water subclade ( $78 \mathrm{MYA}$ ) predates the Cretaceous-Paleogene boundary. The distribution of the recent members of this clade (including the species of Seratifusus reaching subtropical latitudes) is also consistent with an origin of this lineage in the Southern Ocean.

The hypothesis of a Southern Hemisphere origin of the entire Austrosiphonidae-Tudiclidae clade needs to be revisited in the light of the new phylogenetic hypotheses obtained in the present study. Vaux et al (2017) recovered the genera Buccinulum, Aeneator, Antarctoneptunea, Penion and Kelletia as a single clade, with an estimated origin at 116 MYA in the AptianAlbian. The Recent species of the former three genera inhabit Southern temperate or polar water, whereas Kelletia by early Miocene has extended its distributon to the the Northern Hemisphere (Hayashi, 2005), and its living species occur in NE and NW Pacific. Nevertheless, Vaux et al (2017) noted the possible paraphyly of this group in relation to some Northern Hemisphere buccinoidean lineage(s). Our results confirm this suspicion and change the concept of Buccinulidae, in particular by demonstrating a close affinity of the Buccinulum-Aeneator subclade of the former Buccinulidae to the East African Afer, Indian Tudicla, and widely distributed Euthria. However, the taxa from temperate Australia (Tasmeuthria clarkei) and Norfolk Ridge (three species formerly placed in Euthria) are sister to the rest of the Tudiclidae. Thus, if we accept an origin of the Austrosiphonidae-Tudiclidae clade in the Southern Ocean, in 
the most parsimonious scenario, one northward dispersal event for the Afer-Tudicla-Euthria lineage (see the cox1 tree on Fig. S1) is required to explain the current distribution of the Tudiclidae. If we hypothesize that the family has originated elsewhere, three independent southward dispersals are required: for the ancestral Austrosiphonidae, for Tasmeuthria, and for the Aeneator-Buccinulum subclade of the Tudiclidae. The first scenario certainly seems more plausible. The northwards dispersal of Afer-Tudicla-Euthria might have been a 'hitchhike' with the concurrent drift of the Indian plate, with subsequent spread of taxa to the Tethys, temperate Pacific and East Africa, or could have proceeded along the eastern continental shelf of Africa. As remarked by Vaux et al. (2017), also based on previous conclusions (Donald et al., 2015), the Southern Hemisphere whelk lineages have non-planktotrophic larval development (except probably Austrofusus), thus implying limited dispersal abilities in timeframes of one or few generations, but range shifts happen over millions of years.

Thus, our results support the notion that, in the late Mesozoic and early Cenozoic, Southern Ocean waters were an arena of buccinoidean diversification that coincided with major diversification events in other lineages of carnivorous gastropods in the Aptian-Albian ages of the late Early Cretaceous (Taylor et al., 1980; Strong et al., 2019).

\section{FUTURE WORK}

Priority should now be given to expand taxonomic sampling by including genera of uncertain affinities, such as the Antarctic and Magellanic Falsitromina, Anomacme, Drepanodontus, Meteuthria, etc., and the Arctic-North Pacific Liomesus, Latisipho,Troschelia, etc., which may well result in the detection of additional family-level lineages. In a broader context, further efforts are needed to generate a supported backbone phylogeny of Buccinoidea, infer timing of the lineage diversification and review the fossil record in light of the inferred phylogenetic relationships.

\section{ACKNOWLEDGEMENTS}

A large part of the molecular material in this paper originates from various shore-based expeditions and deep sea cruises, conducted respectively by MNHN and Pro-Natura International (PNI) as part of the Our Planet Reviewed programme, and by MNHN and Institut de Recherche pour le Développement (IRD) as part of the Tropical Deep-Sea Benthos programme. Funders, sponsors and partners include the Total Foundation, Prince Albert II of Monaco Foundation, Stavros Niarchos Foundation, Richard Lounsbery Foundation, and the Philippines Bureau of Fisheries and Aquatic Resources (BFAR). We thank, among others, Virginie Héros, Philippe Maestrati, Barbara Buge, and Ellen Strong for their role in specimen processing during the expeditions and in MNHN.

We are very thankful to our colleagues who collected or made availble to us key material from different parts of the world, particularly Stefano Schiaparelli (Italian National Antarctic Museum, Genova), Enrico Schwabe (Bavarian State Collection of Zoology, Munich), Serge Gofas (Universidad de Málaga), Christiane Delongueville and Roland Scaillet (Brussels), Jónbjörn Pálsson and Steinunn Hilma Ólafsdóttir (Marine and Freshwater Research Institute, Hafnarfjórdur, Iceland), Marco Oliverio (Sapienza University, Rome), Douglas Eernisse (California State University, Fullerton), Francesco Criscione (Australian Museum, Sydney), Ivan Nekhaev (Saint-Petersburg University). Felix Vaux shared with us molecular data on New Zealand and Australian species, Bruce Marshall assisted with the specimens and photographs 
from NMNZ. S. Zvonareva and E. Mekhova (IEEE) assisted in collection of material in Vietnam and helped with photography.

Material from Japanese waters were collected during cruises with the research vessels Shinsei-maru, Tansei-maru and Nagasaki-maru; our special thanks go to Kazuhiro Kogure, Shigeaki Kojima, Toshi Nagata (AORI) and Jun Hashimoto (Nagasaki University) for organizing the cruises, and to Hiroaki Fukumori, Genki Ishiyama (AORI) and Tsuyoshi Takano (Meguro Parasitological Museum) for sorting and processing the specimens. Material from the abyssal depth in Kuril-Kamchatka Trench was collected mostly during the Joint German-Russian research cruise KuramBio I on R/V Sonne in 2012 (cruise leaders Angelika Brandt and Marina V. Malyutina).

We thank Guido Pastorino, M.G. Harasewych, Daniel Abbate, and Scott Johnson who kindly provided photos of radulae and shells; Guido and Philippe Poppe for photographs of shells; Koen Fraussen and Martin A. Snyder for help in identification; and Alan Beu for his valuable comments on the manuscript. Dr. E.G. Zavarzina-Memmi assisted in handling the specimens.

The study was conducted using Joint Usage Center "Instrumental methods in ecology" at the IEE RAS. We thank A. Neretina and A. Nekrasov for their friendly and helpful assistance with the SEM facilities.

The contributions of Yu. Kantor, A. Kosyan, P. Sorokin and A. Fedosov were supported by Russian Science Foundation (grant No. 16-14-10118-П, PI Yu. Kantor). This project has received funding from the European Research Council (ERC) under the European Union's Horizon 2020 research and innovation programme (grant agreement No. 865101). Financial support was also provided by JSPS KAKENHI grants to Y. Kano (Nos 18H02494 and 19H00999).

\section{REFERENCES}

Abbate D, Simone LRL, Cavallari DC. 2018. Anatomy of Engoniophos unicinctus from Isla Margarita, Venezuela (Gastropoda:Caenogastropoda: Nassariidae), with a discussion of buccinid-nassariid relationship, The Nautilus 132: 101-112.

Abbate D, Simone LRL. 2015. Review of Pugilina from the Atlantic, with description of a new species from Brazil (Neogastropoda, Melongenidae), African Invertebrates 56: 559-577.

\section{Aissaoui C, Puillandre N, Bouchet P, Fassio G, Modica MV, Oliverio M. 2016. Cryptic} diversity in Mediterranean gastropods of the genus Aplus (Neogastropoda: Buccinidae), Scientia Marina 80: 521-533.

Bandel K. 1984. The radula of Caribbean and other Mesogastropoda and Neogastropoda, Zoologische Verhandelingen 214: 1-188.

Beu AG. 1979. Bathyal Nukumaruan Mollusca from Oaro, southern Marlborough, New Zealand, New Zealand Journal of Geology and Geophysics, 22: 87-103.

Beu AG. 2009. Before the ice: biogeography of Antarctic Paleogene molluscan faunas, Palaeogeography, Palaeoclimatology, Palaeoecology 284: 191-226.

Bouchet P, Perrine D. 1996. More gastropods feeding at night on parrotfishes, Bulletin of Marine Science 59: 224-228.

Bouchet P, Heros V, Lozouet P, Maestrati P. 2008. A quarter-century of deep-sea malacological exploration in the South and West Pacific: Where do we stand? How far to 
go? Tropical Deep-Sea Benthos, volume 25, Mémoires du Muséum National d'Histoire Naturelle 196: 9-40.

Bouchet P, Rocroi J-P. 2005. Classification and nomenclator of gastropod families, Malacologia 47: 1-397.

Bouchet P, Warén A. 1985). Revision of the North-East Atlantic bathyal and abyssal Neogastropoda, excluding Turridae, Bolletino Malacologico Supplement 1: 121-296.

Bouchet P, Warén A. 1986. Taxonomical notes on tropical deep water Buccinidae with descriptions of new taxa. Résultats des campagnes Musorstom, volume 4, Mémoires $d u$ Muséum National d'Histoire Naturelle, ser. A, 133: 457-517.

Bouchet P., Rocroi J-P, Hausdorf B, Kaim A., Kano Y, Nützel A., Parkhaev P., Schrödl M., Strong EE. 2017. Revised classification, nomenclator and typification of gastropod and monoplacophoran families, Malacologia 61: 1-526.

Brown SC. 1969. The structure and function of the digestive system of the mud snail Nassarius obsoletus (Say), Malacologia 9: 447-500.

Callomon P, Lawless AS. 2013. On the recent members of the genus Lirabuccinum Vermeij, 1991 in the Northern Pacific, with description of a new species (Gastropoda: Buccinidae), Venus 71: 13-27.

Cernohorsky WO. 1971. Indo-Pacific Pisaniinae (Mollusca: Gastropoda) and related buccinid genera, Records of the Auckland Institute and Museum 8: 137-167.

Cernohorsky WO. 1984. Systematics of the family Nassariidae (Mollusca: Gastropoda), Bulletin of the Auckland Institute and Museum 14: 1-356.

Cernohorsky WO. 1984. The family Buccinidae. Part 1. The genera Nassaria, Trajana and Neoteron, Monographs of Marine Mollusca 2(16): 201-284.

Clarke A, Crame JA. 1989. The origin of the Southern Ocean marine fauna. In Crame JA, ed. Origins and evolution of the Antarctic biota, Geological Society Special Publication 47: 253-268.

Cooke AH. 1917. The radula of the genus Euthria, Gray, Proceedings of the Malacological Society of London 12: 232-235.

Cotton B C, Godfrey FK. 1932. South Australian shells (including descriptions of new genera and species) part III, The South Australian Naturalist 13: 35-86, pls. 1-4.

Couto DR, Bouchet P, Kantor YI, Simone LRL, Giribet G. 2016. A multilocus molecular phylogeny of Fasciolariidae (Neogastropoda: Buccinoidea), Molecular Phylogenetics and Evolution 99: 309-322.

Couto DR, Simone LRL. 2019. A morphology-based phylogenetic analysis of Fasciolariidae (Gastropoda: Buccinoidea), Zootaxa 4684: 1-65.

Cowan MT. 1965. The egg capsule and young of the gastropod Pyrulofusus harpa, The Veliger 8: $1-2$.

Crame JA, Beu AG, Ineson JR, Francis JE, Whittle RJ, Bowman VC. 2014. The early origin of the Antarctic marine fauna and its evolutionary implications, PLOS ONE 9: 22.

D'Attilio A. 1981. The radula of Neoteron ariel (Pilsbry and Lowe, 1932) (Gastropoda: Buccinidae), The Festivus 13: 104-105.

Dall WH. 1904. An historical and systematic review of the frog-shells and tritons, Smithsonian Miscellaneous Collections 47: 114-144.

Dall WH. 1906. Early history of the generic name Fusus, Journal of Conchology 11: 289-297. 
Dell RK. 1990. Antarctic Mollusca with special reference to the fauna of the Ross Sea, Bulletin of the Royal Society of New Zealand 27: 1-311.

Donald KM, Winter DJ, Ashcroft AL, Spencer HG. 2015. Phylogeography of the whelk genus Cominella (Gastropoda: Buccinidae) suggests long-distance counter-current dispersal of a direct developer, Biological Journal of the Linnean Society 115: 315-332.

Durham JW, MacNeil FS. 1967. Cenozoic migrations of marine invertebrates through the Bering Strait region. In: Hopkins DM, ed. The Bering land bridge. Stanford, CA: Stanford University Press, 326-349.

Fedosov AE, Caballer M, Buge B, Sorokin PV, Puillandre N, Bouchet P. 2020. Mapping the missing branch on the Neogastropoda tree of life: molecular phylogeny of marginelliform gastropods, Journal of Molluscan Studies 85: 440-452.

Fedosov AE, Puillandre P, Kantor YI, Bouchet P. 2015. Phylogeny and systematics of mitriform gastropods (Mollusca: Gastropoda: Neogastropoda), Zoological Journal of the Linnaean Society 175: 336-359.

Finlay HJ. 1928. The recent mollusca of the Chatham Islands, Transactions and Proceedings of the Royal Society of New Zealand 59: 232-286, pls 38-43.

Fraussen K, Hadorn R. 2000. Transfer of Afer Conrad, 1858 to Buccinidae (Neogastropoda) with description of a new species from western Africa, Gloria Maris 38: 28-42.

Fraussen K, Hadorn R. 2001. A new species of Buccinidae from the Philippine Islands, Novapex 2: 93-96.

Fraussen K, Stahlschmidt P. 2015. An extensive radiation of the genus Crassicantharus Ponder, 1972 (Gastropoda: Buccinoidea) in French Polynesia, with description of nine new species, Novapex 16: 65-80.

Fraussen K, Stahlschmidt P. 2016. Revision of the Clivipollia group (Gastropoda: Buccinidae: Pisaniinae) with description of two new genera and three new species, Novapex 17: 29-46.

Fretter V, Graham A. 1962. British prosobranch molluscs. Their functional anatomy and ecology. Ray Society, London.

Galindo LA, Puillandre N, Strong EE, Bouchet P. 2014. Using microwaves to prepare gastropods for DNA barcoding, Molecular Ecology Resources 14: 700-705.

Galindo LA, Puillandre N, Utge J, Lozouet P, Bouchet, P. 2016. The phylogeny and systematics of the Nassariidae revisited (Gastropoda, Buccinoidea), Molecular Phylogenetics and Evolution 99, 337-353.

Gladenkov YB, Sinelnikova VN, Titova LV. 1988. Stages of development of the fauna of the shelf basins of the Neogene of Kamchatka (on the example of buccinids). In: Lithology and stratigraphy of the Mesozoic and Cenozoic of the eastern regions of the USSR. Moscow: "Nauka": 58-135.

Gofas S, Oliver JD. 2010. Las especies del género Chauvetia ( Gastropoda, Neogastropoda, Buccinidae) del área ibero-marroquí, con descripción de cuatro especies nuevas, Iberus, 28: 23-60.

Golikov AN. 1963. Gastropod molluscs of the genus Neptunea Bolten. Fauna of the USSR, Molluscs, 5(1). Leningrad, Nauka: 1-217.

Golikov AN. 1980. Molluscs Buccininae of the World Ocean. Fauna of the USSR, Molluscs, 5(2). Leningrad, Nauka: 1-466. 
Goryachev VN. 1987. On the revision of the gastropod superfamily Buccinoidea (Mollusca, Gastropoda, Hamiglossa). The nontropical zones of the Northern Hemisphere. In: Vsesoiuznoe soveshchanie po izucheniiu molliuskov [Leningrad] 8: 31-35.

Gray JE. 1857. Guide to the systematic distribution of Mollusca in the British museum. Part I. Taylor \& Francis, London.

Gulbin VV. 2018. The egg cases and capsules of the gastropod Beringius marshalli (Dall, 1919) (Gastropoda: Buccinidae: Beringiinae). Ruthenica, Russian Malacological Journal 28: 8386.

Guralnick R, deMaitenon M. 1997. Formation and homology of radular teeth; A case study using columbellid gastropods (Neogastropoda: Columbellidae), Journal of Molluscan Studies 63: 65-77.

Habe T, Sato J. 1973 ["1972"], [A classification of the family Buccinidae from the North Pacific], Proceedings of the Japanese Society of Systematic Zoology 8: 1-8, pls 1-2.

Habe T. 1972. Notes on the genus Parancistrolepis Azuma (Buccinidae), The Nautilus 86: 5152.

Hain SG. 1990. Beiträge zur Biologie der beschalten Mollusken (K1. Gastropoda und Bivalvia) des Weddellmeeres, Antarktis, Berichte zur Polarforschung 70: 1-181.

Harasewych MG, Kantor YI, Linse K. 2000. Parabuccinum, a new genus of Magellanic buccinulid (Gastropoda: Neogastropoda), with a description of a new species, Proceedings of the Biological Society of Washington 113: 542-560.

Harasewych MG. 1991. Mollusca Gastropoda: Columbariform gastropods of New Caledonia. In: A Crosnier \& P. Bouchet (eds), Résultats des Campagnes Musorstom, volume 7, Mémoires du Muséum National d'Histoire Naturelle, ser. A 150: 243-259.

Harasewych MG. 2018. The anatomy of Tudicla spirillus (Linnaeus, 1767) and the relationships of the Tudiclidae (Gastropoda: Neogastropoda), The Nautilus 132: 35-44.

Hardy SM, Carr CM, Hardman M. et al. 2011. Biodiversity and phylogeography of Arctic marine fauna: insights from molecular tools, Marine Biodiversity 41: 195-210.

Hasegawa K. 2009. Upper bathyal gastropods of the Pacific coast of northern Honshu, Japan, chiefly collected by R/V Wakataka-maru. In: Fujita T. (ed.), Deep-sea fauna and pollutants off Pacific coast of northern Japan, National Museum of Nature and Science Monographs 39: $225-383$.

Hayashi S. 2005. The molecular phylogeny of the Buccinidae (Caenogastropoda: Neogastropoda) as inferred from the complete mitochondrial 16S rRNA gene sequences of selected representatives. Molluscan Research. 25(2): 85-98.

Higo S, Callomon P, Goto Y. 1999. Catalogue and bibliography of the marine shell-bearing Mollusca of Japan. Osaka, Elle Scientific Publications.

Huelsenbeck JP, Ronquist F. 2001. MrBayes: bayesian inference of phylogeny. Bioinformatics 17: 754-755.

International Commission on Zoological Nomenclature. 1999, International Code of Zoological Nomenclature, ed. 4. The International Trust for Zoological Nomenclature, London.

Iredale T, McMichael DF. 1962. A reference list of the marine Mollusca of New South Wales, The Australian Museum Memoir 11: 1-185.

Kalyaanamoorthy S, Minh BQ, Wong TKF, von Haeseler A, Jermiin LS. 2017. ModelFinder: Fast Model Selection for Accurate Phylogenetic Estimates, Nature Methods 14: 587-589. 
Kang PA. 1976. Study on the radula of Korean marine gastropods, Bulletin of the Korean Fishery Society 9: 25-34.

Kantor YI. 1988. Gastropods of the subgenus Ancistrolepis (Clinopegma) (Gastropoda, Buccinidae) of the Okhotsk Sea, Zoologicheskii Zhurnal 67: 1126-1140.

Kantor YI. 1990. Gastropods of the subfamily Volutopsiinae (Buccinidae) of the World Ocean. Moscow, Nauka Publ.

Kantor YI. 2003. Comparative anatomy of the stomach of Buccinoidea (Neogastropoda), Journal of Molluscan Studies 69: 203-220.

Kantor YI, Fedosov AE, Puillandre N, Bonillo C, Bouchet P. 2017. Returning to the roots: morphology, molecular phylogeny and classification of the Olivoidea (Gastropoda: Neogastropoda), Zoological Journal of the Linnean Society 180: 493-541.

Kantor YI, Fedosov AE, Snyder MA, Bouchet P. 2018. Pseudolatirus Bellardi, 1884 revisited, with the description of two new genera and five new species (Neogastropoda: Fasciolariidae), European Journal of Taxonomy 433: 1-57.

Kantor YI, Harasewych MG. 2013. Antarctica, where turrids and whelks converge: A revision of Falsimohnia Powell, 1951 (Neogastropoda: Buccinoidea) and a description of a new genus, The Nautilus 127: 43-56.

Kantor YI, Kilburn RN. 2001. Rediscovery of Canidia dorri Wattlebed, 1886, with a discussion of its systematic position (Gastropoda: Neogastropoda: Nassariidae: Nassodonta), The Nautilus 115: 99-104.

Kantor YI, Kosyan A, Sorokin P, Fedosov A. 2020. On the taxonomic position of Phaenomenella Fraussen \& Hadorn, 2006 (Neogastropoda: Buccinoidea) with description of two new species, Zoosystema 42: 33-55.

Kantor YI, Kosyan A, Sorokin P, Herbert DG, Fedosov A. 2020. Review of the abysso-hadal genus Bayerius (Gastropoda: Neogastropoda: Buccinidae) from the North-West Pacific, with description of two new species, Deep-Sea Research Part I 160, 103256: 1-25.

Kantor YI, Puillandre N, Fraussen K, Fedosov AE, Bouchet P. 2013. Deep-water Buccinidae (Gastropoda: Neogastropoda) from sunken wood, vents and seeps: molecular phylogeny and taxonomy, Journal of the Marine Biological Association of the United Kingdom 93: 2177-2195.

Kantor YI, Puillandre N, Rivasseau A, Bouchet P. 2012. Neither a buccinid nor a turrid: A new family of deep-sea snails for Belomitra P. Fischer, 1883 (Mollusca, Neogastropoda), with a review of Recent Indo-Pacific species, Zootaxa 3496: 1-64.

Katoh K, Rozewicki J, Yamada KD. 2019. MAFFT online service: multiple sequence alignment, interactive sequence choice and visualization, Briefings in Bioinformatics 20: 1160-1166.

Keen AM. 1971. Seashells of Tropical West America. Palo Alto, Stanford University Press.

Kosyan AR. 2006. Two new species of the genus Pararetifusus Kosuge, 1967 (Buccinidae: Colinae), with notes on the morphology of Pararetifusus tenuis (Okutani, 1966), Ruthenica, Russian Malacological Journal 16(1-2): 5-15.

Kosyan AR. 2007. Morphological features, ecology, and distribution of poorly studied molluscan genera of the Colinae subfamily (Bastropoda, Buccinidae) from the far eastern seas of Russia, Oceanology 47: 531-536. 
Kosyan AR, Kantor YI. 2004. Morphology, taxonomic status and relationships of Melongenidae (Gastropoda: Neogastropoda). Ruthenica, Russian Malacological Journal 14: 9-36.

Kosyan AR, Kantor YI. 2013. Revision of the genus Aulacofusus Dall, 1918 (Gastropoda: Buccinidae). Ruthenica, Russian Malacological Journal 23: 1-33.

Kosyan AR, Kantor YI. 2014. Revision of the genus Retifusus Dall, 1916 (Gastropoda: Buccinidae). Ruthenica, Russian Malacological Journal 24: 121-163.

Kosyan AR, Kantor YI. 2015. Notes on the abyssal genus Fusipagoda Habe \& Ito, 1965 (Neogastropoda: Buccinidae) from the North Pacific. Ruthenica, Russian Malacological Journal 25: 77-87.

Kosyan AR, Kantor YI. 2016. Revision of the genus Retimohnia McLean, 1995 (Gastropoda: Buccinidae). Ruthenica, Russian Malacological Journal 26: 85-121.

Landau BM, Harzhauser M, İslamoğlu Y, da Silva CM. 2013. Systematics and palaeobiogeography of the gastropods of the middle Miocene (Serravallian) Karaman Basin, Turkey, Cainozoic Research 11-13: 1-584.

Li H, Shi X, Zhou J, Zhou P, Lü X. 2013. Study on the taxonomic status of Afer cumingii based on mitochondrial gene sequences and radular morphology, Marine Sciences 37: 8588.

Linse K. 2002. The shelled Magellanic Mollusca: with special reference to biogeography relations in the Southern Ocean, Theses Zoologicae 34: 1-252.

Luca JD, Pastorino G. 2018. A revision of the genus Savatieria Rochebrune \& Mabille, 1885: an endemic group of buccinulid gastropods from the Magellanic region, Journal of Molluscan Studies 84: 293-302.

Macpherson JH, Chapple EH. 1951. A systematic list of the marine and estuarine Mollusca of Victoria, Memoirs of the National Museum of Victoria 17: 107-185.

Marcus Ev. du B.-R., Marcus Er. 1962. Studies on Columbellidae, Faculdade de Filosofia, Ciencias e Letras da Universidade de Sao Paulo, Boletim 261, Zoologia 24: 335-384.

Marshall BA, Walton K. 2019. A review of Buccipagoda Ponder, 2010 and descriptions of new species and a new genus (Gastropoda: Neogastropoda: Buccinoidea: Buccinidae), Molluscan Research 39: 70-81.

Miller MA, Pfeiffer W, Schwartz T. 2010. Creating the CIPRES Science Gateway for inference of large phylogenetic trees. In: Gateway Computing Environments Workshop (GCE), New Orleans: 1-8.

Numanami H. 1996. Taxonomic study on Antarctic gastropods collected by Japanese Antarctic Research Expeditions, Memoirs of National Institute of Polar Research, Series E (Biology and Medical Science) 39: 1-244.

Okutani T, Iwasaki N, 2003. Noteworthy abyssal mollusks (excluding vesicomyid bivalves) collected from the Nankai Trough off Shikoku by the ROV Kaiko of the Japan Marine Science \& Technology Center, Venus 62, 1-10.

Okutani T. 2017 (ed.) Marine Mollusks in Japan, ed. 2, 2 volumes. Tokai Uniersity Press, Tokyo.

Oliver JD, Rolan E., 2008. Las especies del género Chauvetia del área de Dakar, Senegal, África occidental, con la descripción de diez especies nuevas, Iberus 26: 133-175. 
Oliverio M, Modica MV. 2010. Relationships of the haematophagous marine snail Colubraria (Rachiglossa: Colubrariidae), within the neogastropod phylogenetic framework, Zoological Journal of the Linnean Society 158: 779-800.

Olsson AA. 1971. Mollusks from the Gulf of Panama collected by R/V John Elliott Pillsbury, Bulletin of Marine Science, 21: 35-92.

Orr V. 1956. The South African gastropod genus Burnupena (Buccinidae), Proceedings of the Academy of Natural Sciences of Philadelphia 108: 249-263.

Pastorino G, Griffin M. 2019. Gastropods of the genus Antistreptus as examples of persistent molluscan lineages in the Neogene of the southwestern Atlantic, Journal of Paleontology 93: 916-924.

Pastorino G. 2016. Revision of the genera Pareuthria Strebel, 1905, Glypteuthria Strebel, 1905 and Meteuthria Thiele, 1912 (Gastropoda: Buccinulidae) with the description of three new genera and two new species from Southwestern Atlantic waters, Zootaxa 4179: 301-344

Pearce JB, Thorson G. 1967. The feeding and reproductive biology of the red whelk, Neptunea antiqua (L.) (Gastropoda, Prosobranchia), Ophelia 4: 277-314.

Penchaszadeh P, Pastorino G, Martinez MI, Miloslavich P. 2019. Spawn and development of the gastropod Americominella longisetosa (Castellanos and Fernandez, 1972) (Mollusca: Buccinidae) from the Southwestern Atlantic deep sea, Deep-Sea Research Part 1 143: 4349.

Petuch EJ, Myers RF, Berschauer DP. 2015. The living and fossil Busycon whelks: iconic mollusks of eastern North America. Special Publication of the San Diego Shell Club.

Ponder WF, Warén A. 1988. Classification of the Caenogastropoda and Heterostropha - A list of the family-group names and higher taxa, Malacological Review, Supplement 4: 288328.

Ponder WF. 1968. Anatomical notes on two species of the Colubrariidae (Mollusca, Prosobranchia), Transactions of the Royal Society of New Zealand, Zoology 10: 217-223.

Ponder WF. 1971. A review of the New Zealand recent and fossil species of Buccinulum Deshayes (Mollusca : Neogastropoda : Buccinidae), Journal of the Royal Society of New Zealand 1: 231-283.

Ponder WF. 1972. Notes on some Australian species and genera of the family Buccinidae (Neogastropoda), Journal of the Malacological Society of Australia 2: 249-265.

Ponder WF. 1973. A review of the Australian species of Penion Fischer (Neogastropoda: Buccinidae), Journal of the Malacological Society of Australia 2: 401-428.

Powell AWB. 1951. Antarctic·and Subantarctic Mollusca: Pelecypoda and Gastropoda, Discovery Reports 26: 47-196, pls 5-10.

Rambaut A, Suchard MA, Xie D, Drummond AJ. 2014. Tracer v1.4. in. htt p://beast.bio.ed.ac.uk/Tracer.

Raven JGM. 2016. Notes on molluscs from NW Borneo. 3. A revision of Taurasia (Gastropoda, Muricidae) and Preangeria (Gastropoda, Buccinidae) with comments on Semiricinula from NW Borneo, Vita Malacologica 15: 77-104.

Röding PF. 1798. Museum Boltenianum ..., Pars secunda continens conchylia sive testacea univalvia, bivalvia \& multivalvia. Hamburg.

Rosenthal RJ. 1970. Observations on the reproductive biology of the Kellet's Whelk, Kelletia kelletii, The Veliger 12: 319-324.

Sars GO. 1878. Mollusca Regionis Arcticae Norwegiae. Christiania, Brögger. 
Sela I, Ashkenazy H, Katoh K, Pupko T. 2015. GUIDANCE2: accurate detection of unreliable alignment regions accounting for the uncertainty of multiple parameters, Nucleic Acids Research 43: W7-W14.

Shuto T. 1978. On the genera Siphonofusus and Euthria of the Indo-West Pacific, Transactions and Proceedings of the Palaeontological Society of Japan 111: 358-369.

Simone LRL, Cavallari D, Abbate D. 2013. Revision of the genus Teralatirus Coomans 1965 in the western Atlantic, with an anatomical description of T. roboreus (Reeve 1845) (Gastropoda: Neogastropoda: Fasciolariidae), Archiv für Molluskenkunde 142: 215-226.

Simone LRL, Pastorino G. 2014. Comparative morphology of Dorsanum miran and Bullia granulosa from Morocco (Mollusca: Caenogastropoda: Nassariidae), African Invertebrates 55: $125-142$.

Simone LRL. 1996. Anatomy and systematics of Buccinanops gradatus (Deshayes, 1844) and Buccinanops moniliferus (Kiener, 1834) (Neogastropoda, Muricoidea) from the southeastern coast of Brazil, Malacologia 38: 87-102.

Smith KE, Thatje S. 2013. The subtle intracapsular survival of the fittest: maternal investment, sibling conflict, or environmental effects? Ecology 94: 2263-2274.

Spalding MD, Fox HE, Allen GR, Davidson N, Ferdaña ZA, Finlayson M, Halpern BS, Jorge MA, Lombana A, Lourie SA, Martin KD, Mc Manus E, Molnar J, Recchia CA, Robertson J. 2007. Marine ecoregions of the world: a bioregionalization of coastal and shelf areas, Bioscience 57: 573-583.

Stamatakis A, Hoover P, Rougemont J. 2008. A rapid bootstrap algorithm for the RAxML Web servers, Systematic Biology 57: 758-771.

Stamatakis A. 2006. RAxML-VI-HPC: maximum likelihood-based phylogenetic analyses with thousands of taxa and mixed models, Bioinformatics 22: 2688-2690.

Strong EE, Galindo LA, Kantor YI. 2017. Quid est Clea helena? Evidence for a previously unrecognized radiation of assassin snails (Gastropoda: Buccinoidea: Nassariidae), PeerJ 5: e3638.

Strong EE, Puillandre N, Beu AG, Castelin M, Bouchet P. 2019. Frogs and tuns and tritons - A molecular phylogeny and revised family classification of the predatory gastropod superfamily Tonnoidea (Caenogastropoda), Molecular Phylogenetics and Evolution 130: $18-34$.

Taylor JD, Morris NJ, Taylor CN. 1980. Food specialization and the evolution of predatory prosobranch gastropods, Palaeontology 23: 375-409.

Thiele J. 1912. Die antarktischen Schnecken und Muscheln, Deutschen Sudpolar-Expedition 1901-1903 13: 183-285, pls 11-19.

Tiba R, Kosuge S. 1980. Genus Japelion. North Pacific Shells, Part 6. 14 pp., 6 pls.

UNESCO. 2009. Global Open Oceans and Deep Seabed (GOODS): Biogeographic Classification. UNESCO-IOC, Paris. IOC Technical Series, No. 84.

Vaux F, Hills SFK, Marshall BA, Trewick SA, Morgan-Richards M. 2017. A phylogeny of Southern Hemisphere whelks (Gastropoda: Buccinulidae) and concordance with the fossil record, Molecular Phylogenetics and Evolution 114: 367-381.

Vaux F, Trewick SA, Crampton JS, Marshall BA, Beu AG, Hills SFK, Morgan-Richards M. 2018. Evolutionary lineages of marine snails identified using molecular phylogenetics and geometric morphometric analysis of shells, Molecular Phylogenetics and Evolution 127: 626-637. 
Vermeij GJ, Banker R, Capece LR, et al. 2019. The coastal North Pacific: Origins and history of a dominant marine biota, Journal of Biogeography 46: 1-18.

Vermeij GJ, Snyder MA. 2006. Shell characters and taxonomy of Latirus and related fasciolariid groups, Journal of Molluscan Studies 72: 413-424.

Vermeij GJ, Snyder MA. 2018. Proposed genus-level classification of large species of Fusininae (Gastropoda, Fasciolariidae), Basteria 82: 57-82.

Vermeij GJ. 1991. Anatomy of an invasion: The trans-Arctic interchange, Paleobiology 17: 281-307.

Vermeij GJ. 1991. Generic identity and relationships of the Northeastern Pacific buccinid gastropod Searlesia dira (Reeve, 1846), The Veliger 34: 264-271.

Vermeij GJ. 1998. Generic revision of the neogastropod family Pseudolividae, The Nautilus 111: 53-84.

Vermeij GJ. 2001. Taxonomy, distribution, and characters of pre-Oligocene members of the Cantharus group of Pisaniinae (Neogastropoda: Buccinoidea), Journal of Paleontology75: 295-309.

Watters GT, Finlay CJ. 1989. A revision of the Western Atlantic recent species of the genus Monostiolum Dall, 1904, and Bailya (Parabailya) new subgenus (Gastropoda: Buccinidae), The Veliger 32: 47-59.

Wenz W. 1938-1944. Castropoda. Teil 1: Allgemeiner uud Prosobranchia. Handhuch der Paläozoologie 6. Berlin, Borntraeger.

Zacherl D, Gaines SD, Lonhart SI. 2003. The limits to biogeographical distributions: insights from the northward range extension of the marine snail, Kelletia kelletii (Forbes, 1852), Journal of Biogeography 30: 913-924.

Zou S, Li Q, Kong L. 2011. Additional gene data and increased sampling give new insights into the phylogenetic relationships of Neogastropoda, within the caenogastropod phylogenetic framework, Molecular Phylogenetics and Evolution 61: 425-435.

References to supplementary material (Table 3)

Kosyan AR. 2006. Anatomy and taxonomic composition of the genus Latisipho Dall (Gastropoda: Buccinidae) from the Russian waters, Ruthenica, Russian Malacological Journal 16: 17-42.

Kosyan AR, Kantor YI. 2012. Revision of the genus Plicifusus Dall, 1902 (Gastropoda: Buccinidae), Ruthenica, Russian Malacological Journal 22: 55-92.

Kosyan AR, Modica MV, Oliverio M. 2009. The anatomy and relationships of Troschelia (Neogastropoda: Buccinidae): New evidence for a closer fasciolariid-buccinid relationship?, The Nautilus 123: 95-105.

\section{SUPPORTING INFORMATION}

Fig. S1. Buccinoidea phylogenetic relationships obtained with the Maximum Likelihood (ML) of the coxl gene. The species not included in multigene analysis are highlighted in red.

Fig. S2. Buccinoidea phylogenetic relationships obtained with the Maximum Likelihood (ML) of the multigene dataset (concatenated alignment coxl, 12S, 16S, 28S and $\mathrm{H} 3$ genes). For 
Japeuthria ferrea (highlighted in red) concatenated alignment of three genes (cox 1, 16S, and H3) was used.

Table S1. List of sequenced species included in the molecular analysis with collecting details and not-alligned sequences.

Table S2. List of genera of Buccinoidea with uncertain familiar allocation.

Cox1 dataset:

File S1_Buc2021_COI_all.fas. Cox1 alignment used to reconstruct a phylogenetic tree on the Fig. S1.

File S2_Buc2021_COI_all_GTR.contree. IQtree output consensus tree (Fig. S1)

5 genes dataset:

File S3_Buc5G_230_GUI40c.fas. Concatenated alignment of 5 genes (cox1-16S-12S-H3-28S) after removal of the columns with confidence values below 0.4 from $16 \mathrm{~S}$ and $12 \mathrm{~S}$.

File S4_Buc5G_230_GUI90.fas. Concatenated alignment of 5 genes (cox1-16S-12S-H3-28S) after removal of the columns with confidence values below 0.9 from $16 \mathrm{~S}$ and $12 \mathrm{~S}$.

File S5_Buc5G_231_final.fas. Concatenated alignment of 5 genes (cox1-16S-12S-H3-28S) used for final Bayesian and RaxML analyses on the 5 genes dataset (Figs 1,2).

File S6_Buc5G_231_final_best_models.txt. Output of the Model finder as implemented in the IQtree for the final 5 genes dataset.

File S7_Buc231_5Gbest_model_RAxML_bipartitions.result. Output tree file produced by RaxML for the dataset Buc5G_231_final.fas with partitions as specified in Buc5G_231_final_best_models.txt.

File S8_Buc231_5Gbest_model_BA.nex.con. Consensus tree file generated after summing two *.t files from the Bayesian analysis of the dataset Buc5G_231_final.fas with partitions as specified in Buc5G_231_final_best_models.txt, and discarding 25\% trees from first generations of MCMC.

File S9_Buc5G_232_final_Japeuthria.fas. Alignment Buc5G_231_final.fas, with additional hymeric entry for Japeuthria ferrea, represented by 3 genes, coxl, 16S, and H3, all obtained from GenBank. Used for analysis to generate the tree on the fig S2.

File S10_Buc5G-6_Japeuthria.contree. IQtree consensus tree resulting from the analysis of the Buc5G_232_final_Japeuthria.fas with partitions as specified in Buc5G_231_final_best_models.txt. 


\section{FIGURE CAPTIONS}

Figure 1. Buccinoidea phylogenetic relationships obtained with the Bayesian Inference (BI) of the multigene Buc5G dataset (concatenated alignment coxl, 12S, 16S, 28S and H3 genes). Bootstrap values $(\mathrm{B}>70 \%)$ and posterior probabilities $(\mathrm{PP} \geq 0.95)$ are shown above each nodes. The clades containing multiple samples are collapsed.

Figure 2 ( 3 parts). Buccinoidea phylogenetic relationships obtained with the Maximum Likelihood (ML) and the Bayesian Inference (BI) of the multigene dataset (concatenated alignment coxl, 12S, 16S, 28S and $\mathrm{H} 3$ genes). Bootstrap values (B $>70 \%)$ and posterior probabilities $(\mathrm{PP} \geq 0.95)$ are shown above each nodes. The names of the family group taxa are provided according to the classification accepted in the present work.

Figure 3. Shells of Dolicholatiridae (A-D) and Belomitridae (E-F). A. Dolicholatirus sp., Western Australia, Esperance, 11 m, MNHN IM-2009-29739, sequenced specimen (radula, see Fig. 4A). B. Dolicholatirus spiceri (Tenison Woods, 1876), MNHN IM-2013-42515. C. Dolicholatirus lancea (Gmelin, 1791), Vietnam, Nha-Trang Bay, Mun I., south side, SL 42.5 mm (radula, see Fig. 4C). D. Crassicantharus noumeensis, Marshall Is., Gehh I., Kwajalein Atoll, 16 m, SL $18.2 \mathrm{~mm}$ (photo Scott Johnson). E. Dolicholatirus n.sp., southern New Caledonia, KANACONO st. DW4661, 22 $2^{\circ} 45^{\prime} \mathrm{S}, 167^{\circ} 13^{\prime} \mathrm{E}, 400-405 \mathrm{~m}$, SL $7.0 \mathrm{~mm}$, MNHN IM2013-68545, sequenced specimen. F. Belomitra paschalis (Thiele, 1925), Mozambique,

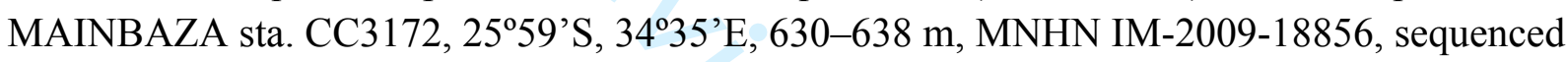
specimen, SL $15.0 \mathrm{~mm}$ (radula, see Fig. 4D). G. Belomitra bouteti Kantor, Puillandre, Rivasseau $\&$ Bouchet, 2012, holotype, French Polynesia, Society Is., TARASOC st. 3436, 16² $43^{\text {'S, }}$ $151^{\circ} 26^{\prime} \mathrm{W}, 430 \mathrm{~m}$, MNHN IM-2007-24478, SL 32.6 mm (radula, see Fig. 4E).

Figure 4. Radulae of Dolicholatiridae and Belomitridae. A. Dolicholatirus sp., Western Australia, Esperance, 11 m, MNHN IM-2009-29739 (shell, see Fig. 3A). B. Dolicholatirus cayhuesonicus (G.B.Sowerby II, 1879), Guadeloupe, KARUBENTHOS 2012 st. GS07, 12 m, MNHN IM-2013-20291. C. Dolicholatirus lancea (Gmelin, 1791), Vietnam, Nha-Trang Bay, Mun I., south side, SL $43.5 \mathrm{~mm}$ (shell, see Fig. 3C). D. Belomitra paschalis (Thiele, 1925), Mosambique,

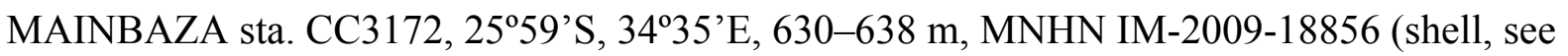
Fig. 3F). E. Belomitra bouteti Kantor, Puillandre, Rivasseau \& Bouchet, 2012, holotype, French Polynesia, Society Is., TARASOC st. 3436, $16^{\circ} 43^{\prime} \mathrm{S}, 151^{\circ} 26^{\prime} \mathrm{W}, 430 \mathrm{~m}$, MNHN IM-2007-24478, SL 32.6 mm (shell, see Fig. 3G). F. Belomitra brachytoma (Schepman, 1913), Taiwan 2000 st. CP32, 22 $01.7^{\circ} \mathrm{S}, 120^{\circ} 16.4^{\prime} \mathrm{E}, 904 \mathrm{~m}, \mathrm{MNHN}$ unregistered.

Scale bars A-D $-10 \mu \mathrm{m}, \mathrm{E}-\mathrm{F}-50 \mu \mathrm{m}$.

Figure 5. Shells of Colubrariidae (A-E) and Colidae (F-L). A. Colubraria muricata ([Lightfoot, 1786]), Philippines, Mactan I., Punta Engaño, 10-25 m, SL 77.1 mm, (C) Guido \& Philippe Poppe - www.conchology.be. B. Cumia reticulata (Blainville, 1829), Mediterranean France, SL 41.3 mm, (c) Guido \& Philippe Poppe - www.conchology.be. C. Kanamarua adonis

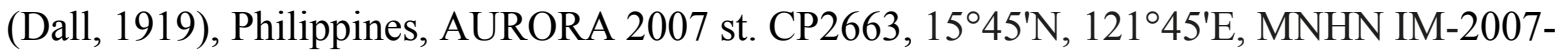
34640, SL $25.8 \mathrm{~mm}$, sequenced specimen. D. Metula inflata (Houbrick, 1984), Philippines, PANGLAO 2005. st. CP2348, 9³0'N, 12352'E, 196-216 m, MNHN IM-2007-30079 SL 42.6 
mm, sequenced specimen. E. Metula sp., Philippines, AURORA 2007 st. CP2709, 15²12'N, 1213'ㄹ, 244 -296 m, MNHN IM-2007-34641, SL 37 mm, sequenced specimen. F. Colus islandicus (Møller, 1842), Iceland, $67^{\circ} 16^{\prime} \mathrm{N}, 15^{\circ} 26^{\prime} \mathrm{W}, 296-306 \mathrm{~m}, \mathrm{MNHN}$ IM-2013-78004, SL $100.3 \mathrm{~mm}$, sequenced specimen. G. Colus gracilis (da Costa, 1778), Iceland, $66^{\circ} 33^{\prime} \mathrm{N}, 25^{\circ} 03^{\prime} \mathrm{W}$, 187-222 m, MNHN IM-2013-78018, SL 53.8 mm, sequenced specimen. H. Colus turigulus (Friele, 1877), Iceland, $67^{\circ} 25^{\prime} \mathrm{N}, 1^{\circ} 24.5^{\prime} \mathrm{W}, 906-942 \mathrm{~m}$, MNHN IM-2013-78007, SL $61.2 \mathrm{~mm}$, sequenced specimen. I. Colus holboelli (Møller, 1842), Iceland, $67^{\circ} 02^{\prime} \mathrm{N}, 23^{\circ} 00^{\prime} \mathrm{W}, 236-243 \mathrm{~m}$, MNHN IM-2013-78017, SL 35.7 mm, sequenced specimen. J. Colus sabinii (Gray, 1824), Iceland, 643' $\mathrm{N}, 10^{\circ} 28^{\prime} \mathrm{W}, 451-478 \mathrm{~m}$, MNHN IM-2013-78014, sequenced specimen. $\mathbf{K}$. Turrisipho voeringii Bouchet \& Warén, 1985 , Iceland, $67^{\circ} 18^{\prime} \mathrm{N}, 23^{\circ} 30.5^{\prime} \mathrm{W}, 395-408 \mathrm{~m}, \mathrm{MNHN}$ IM-2013-78002, SL 40.4 mm, sequenced specimen. L. Turrisipho moebii (Dunker \& Metzger, 1875), Iceland, $64^{\circ} 21^{\prime} \mathrm{N}, 12^{\circ} 56^{\prime} \mathrm{W}, 149-152 \mathrm{~m}$, MNHN IM-2013-78009, SL $35.4 \mathrm{~mm}$, sequenced specimen.

Figure 6. Radulae of Colubrariidae (A-C), Colidae (D) and Eosiphonidae fam. nov. (E-L). A. Colubraria muricata ([Lightfoot, 1786]) (after Oliverio \& Modica, 2010, photo A. Kosyan). B. Cumia mestayerae (Iredale, 1915) (7) and Iredalula striata (Hutton, 1873) (9) (after Ponder, 1968). C. Metula sp., South India, off Tutticorin, from fishermen, IEE uncataloged, SL $35.2 \mathrm{~mm}$. D. Colus islandicus (after Kosyan \& Kantor 2009: fig. 41). E. Enigmaticolus nipponensis (Okutani \& Fujiwara, 2000), Madagascar, MIRIKY st. CP3279, 15²1'S, 4557'E, 780-1020 m, MNHN IM-2009-7079 (shell see on Fig. 7A). F. Manaria kuroharai Azuma, 1960, China Sea, ZHONGSHA 2015 st. CP4152, 165'N, 1135'ㄹ, 410-412 m, MNHN IM-2013-59292, SL 47.7 mm (shell see on Fig. 7I). G. Gaillea cf canetae (Clench \& Aguayo, 1944), Guadeloupe, KARUBENTHOS 2 st. CP4513, 16²13'N, 61 ${ }^{\circ} 54$ 'W, 406-644 m, MNHN IM-2013-60080 (sequenced specimen). H. Eclectofusus sp., Papua-New Guinea, PAPUA NIUGINI st. CP3949, 5¹2'S, 145 51'E, 380-407 m, MNHN IM-2013-4813 (sequenced specimen). I. Eclectofusus dedonderi (Fraussen \& Hadorn, 2001), paratype, Philippines, Balicasag I., tangle nets at 120-150 m, coll. KF-3206 (shell, see Fig. 7G). J. Eosiphonidae Gen. sp., Guadeloupe, KARUBENTHOS 2 st. CP4543, $16^{\circ} 40^{\prime} \mathrm{N}, 61^{\circ} 34^{\prime} \mathrm{W}, 385-399$ m, MNHN IM-2013-60365 (shell, see Fig. 7L). K. Warenius sp., China Sea, ZHONGSHA 2015 st. CP4134, 1950'N, 116²7'E, 1128-1278 m, MNHN IM-2013-61665 (sequenced specimen). L. Americominella longisetosa (Castellanos \& Fernandez, 1972) (after Penchaszadeh et al., 2019, photo G. Pastorino

Scale bars: A, K $-50 \mu \mathrm{m}, \mathrm{C}, \mathrm{H}, \mathrm{J}-20 \mu \mathrm{m}, \mathrm{D}-500 \mu \mathrm{m}, \mathrm{E}, \mathrm{F}, \mathrm{G}, \mathrm{L}-100 \mu \mathrm{m}$

Figure 7. Shells of Eosiphonidae fam. nov. A. Enigmaticolus nipponensis (Okutani \& Fujiwara, 2000), Madagascar, MIRIKY st. CP3279, 15²1'S, 4557'E, 780-1020 m, MNHN IM2009-7079, SL 99.4 mm, sequenced specimen (radula, see Fig. 6A). B. Thermosipho auzendei (Warén \& Bouchet, 2001), holotype, central Pacific, Rehu hydrothermal site, Nautile dive NAUDUR: stn ND18'0-1B, 17²4.85'S 113²12.15'W, 2578 m, MNHN IM-2000-7049, SL 62 mm. C. Eosipho smithi (Schepman, 1911), Vanuatu, SANTO 2006 st. AT103, 150'38"S; 16651'E, 373-721 m, MNHN IM-2007-32983, SL 56.1 mm. D. Calagrassor bacciballus Fraussen \& Stahlschmidt, 2016, Philippines, Bohol Sea, PANGLAO 2005 st. CP2356, 9²1'N ;

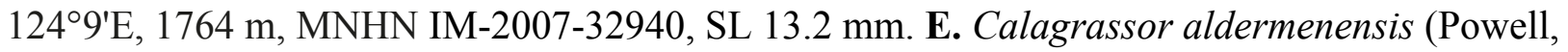

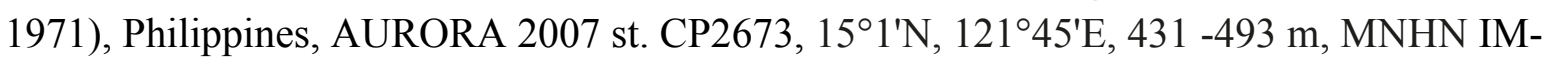
2007-34635, SL 20.7 mm, sequenced specimen. F. “Manaria” fluentisona Fraussen \& 
Stahlschmidt, 2016, holotype, Solomon Is., SALOMONBOA 3 st. DW2790, $8^{\circ} 19^{`} \mathrm{~S}, 160^{\circ} 37^{`} \mathrm{E}$, 314-586 m, MNHN IM-2007-35942, SL 15.4 mm. G. Eclectofusus dedonderi (Fraussen \& Hadorn, 2001) paratype 12, Philippines, Balicasag I., tangle nets at 120-150 m, coll. KF-3206, SL 11.6 mm. H. Manaria formosa Bouchet \& Warén, 1986, Madagascar, MIRIKY st. CP3183, $12^{\circ} 38^{\prime} \mathrm{S}, 48^{\circ} 14^{\prime} \mathrm{E}, 420-436 \mathrm{~m}, \mathrm{MNHN}$ IM-2007-36855, SL 55 mm. I. Manaria kuroharai Azuma, 1960, China Sea, ZHONGSHA 2015 st. CP4152, 16² $5^{\prime} \mathrm{N}, 113^{\circ} 55^{\prime} \mathrm{E}, 410-412 \mathrm{~m}$, MNHN IM-2013-59292, SL 47.7 mm, sequenced specimen (radula see Fig. 6F). J. Gaillea coriolis (Bouchet \& Warén, 1986), Philippines, AURORA 2007 st. CP2699, 145ㅇ'N, 1233ํ'E , 541583 m, MNHN IM-2007-34637, SL 31 mm. K. Calagrassor sp. 2, Papua-New Guinea, PAPUA NIUGINI st. CP4048, 320'S, 1432ㅇ'E, 325-345 m, MNHN IM-2013-18794, sequenced specimen. L. Eosiphonidae Gen. sp., Guadeloupe, KARUBENTHOS 2 st. CP4543, $16^{\circ} 40^{\prime} \mathrm{N}$, 613'ㄴ'W, 385-399 m, MNHN IM-2013-60365, SL $11.3 \mathrm{~mm}$, sequenced specimen (radula, see Fig. 6J). M. Aulacofusus hiranoi (Shikama, 1962), Japan, 3700’'N, 141³9’'E, 557-561 m, AORI_YK\#3406, SL 35.4 mm, sequenced specimen. N. Preangeria dentata (Schepman, 1911), Philippines, PANGLAO 2005 st. CP2349, 9³2'N, 1235'', 219 -240 m, IM-2007-32656, SL $22.8 \mathrm{~mm}$. O. Warenius crosnieri (Bouchet \& Warén, 1986), holotype, Madagascar, N/O"Vauban" st. CH138, 1349'S 47²9'E, 1800-2000 m, MNHN IM-2000-6369, SL 33.7 mm. P. Americominella longisetosa (Castellanos \& Fernandez, 1972) (after Penchaszadeh et al., 2019), SL $98 \mathrm{~mm}$, photo G. Pastorino.

Figure 8. Shells of Prosiphonidae. A-B. Antarctodomus thielei (Powell, 1958), Ross Sea, Antarctica, $65^{\circ} 25^{\prime} \mathrm{S}, 160^{\circ} 53^{\prime} \mathrm{E} .114 \mathrm{~m}$, MNA00183, SL $18 \mathrm{~mm}$, sequenced specimen. C. Antarctodomus cf. powelli Dell, 1995, Tasmania, NC0009, SL $42.1 \mathrm{~mm}$, sequenced specimen. D. Austrofusus glans (Röding, 1798), New Zealand, South Island, Nelson, Collingwood, Pakawai, USNM 601959, SL 40 mm. E. Cavineptunea cf. monstrosa Powell, 1951, Bransfield Strait, Antarctica, MNA11734, SL 39.8 mm, sequenced specimen. F. Chlanidota signeyana Powell, 1951, Bransfield Strait, Antarctica, MNA6718. SL 33.5 mm, sequenced specimen. G. Falsimohnia innocens (E.A.Smith, 1907), Bransfield Strait, Antarctica, MNA11387, SL 5.6 mm, sequenced specimen. H. Falsimohnia minor (Strebel, 1908), Bransfield Strait, Antarctica, MNA1 1409, SL 6.5 mm, sequenced specimen. I. Proneptunea sp., Bransfield Strait, Antarctica, MNA11364, SL 6.1 mm, sequenced specimen. J. Probuccinum tenerum (E.A.Smith, 1907), Bransfield Strait, Antarctica, MNA11740, SL 17.4 mm. K. Prosipho spiralis Thiele, 1912, Bransfield Strait, Antarctica, MNA11398, SL $7.1 \mathrm{~mm}$, sequenced specimen. L. Prosipho mundus E.A.Smith, 1915, Ross Sea, Antarctica, 454 m, MNA6308, SL 7.6 mm, sequenced specimen. M. Drepanodontus tatyanae Harasewych \& Kantor, 2004, holotype, Scotia Sea, Antarctica, 59²'S, 51 $1^{\circ} 53^{\prime} \mathrm{W}, 3010-3510 \mathrm{~m}$, USNM 1010544, SL $43.1 \mathrm{~mm}$. N. Neobuccinum eatoni (E.A.Smith, 1875), Antarctica, South Shetland Is., King George I., 62 $10^{\prime}$ S, 5744'W, 610-625 m, USNM 897630, SL 39 mm. O. Germonea rachelae Harasewych \& Kantor, 2004, holotype, Antarctica, off South Georgia I., 5802'S, 3757'’W, 3197-3239 m, USNM 896594, SL 61.8 mm. P. Muffinbuccinum catherinae Harasewych \& Kantor, 2004, holotype, South Atlantic Ocean [Argentine Abyssal Plain], 47 $17^{\prime} \mathrm{S}, 4^{\circ} 46^{\prime} \mathrm{W}$, 5685-5798 m, USNM 1010623, SL 26.4 mm.

Figure 9. Radulae of Prosiphonidae. A. Neobuccinum eatoni (E.A.Smith, 1875), Antarctica, Adélie Land, 66³5'S, $143^{\circ} 5^{\prime} \mathrm{E}, 862-875$ m, MNHN IM-2009-8220. B. Falsimohnia

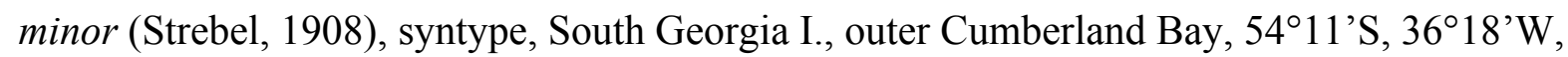


252-310 m, SMNH Type-1057. C. Muffinbuccinum catherinae Harasewych \& Kantor, 2004, paratype 1, South Atlantic Ocean [Argentine Abyssal Plain], 47 $17^{\prime} \mathrm{S}, 47^{\circ} 46^{\prime} \mathrm{W}, 5685-5798 \mathrm{~m}$, USNM 1010624. D. Germonea rachelae Harasewych \& Kantor, 2004, holotype, off South Georgia I., 5802' S, 3757"W, 3197-3239 m, USNM 896594. E. Drepanodontus tatyanae Harasewych \& Kantor, 2004, paratype 1, E of South Sandwich Is., 5700'S, 26¹0'W, 2740- 2757 m, USNM 881529. F. Falsimacme kobelti (Strebel, 1905), Argentina, photo G. Pastorino. G-H. Argeneuthria cerealis (Rochebrune \& Mabille, 1885), Tierra del Fuego, photo G. Pastorino. I. Antistreptus magellanicus (Dall, 1902), Argentina, $37^{\circ} 35^{\prime} \mathrm{S}, 56^{\circ} 25^{\prime} \mathrm{W}, 73 \mathrm{~m}$, photo G. Pastorino Scale bars: A, C, D, E - $100 \mu \mathrm{m}, \mathrm{B}, \mathrm{I}-10 \mu \mathrm{m}, \mathrm{F}, \mathrm{G}, \mathrm{H}-30 \mu \mathrm{m}$.

Figure 10. Shells of Buccinidae. A. Buccinum chishimanum Pilsbry, 1904, Japan,

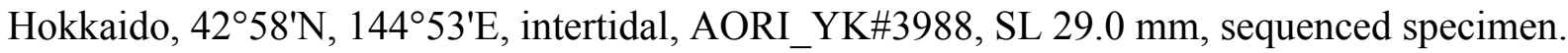
B. Buccinum nipponense Dall, 1907, Japan, Honshu I., $38^{\circ} 25^{\prime} \mathrm{N}, 142^{\circ} 00^{\prime} \mathrm{E}, 342-343 \mathrm{~m}$, AORI_YK\#3989, SL 40.8 mm, sequenced specimen. C. Thysanobuccinum sp., Japan, Honshu I., $39^{\circ} 25^{\prime} \mathrm{N}, 143^{\circ} 10^{\prime} \mathrm{E}, 1950-2051 \mathrm{~m}$, AORI_YK\#3408, SL $22.4 \mathrm{~mm}$, sequenced specimen. D. Ovulatibuccinum cf. fimbriatum (Golikov \& Sirenko, 1988), Japan, Honshu I., 38² $25^{\prime} \mathrm{N}$, $142^{\circ} 00^{\prime} \mathrm{E}, 342-343 \mathrm{~m}$, SL $9.0 \mathrm{~mm}$, sequenced specimen. E. Bathybuccinum bicordatum Golikov \& Sirenko, 1988, Japan, Honshu I., 38 ${ }^{\circ} 5^{\prime} \mathrm{N}, 142^{\circ} 00^{\prime} \mathrm{E}, 342-343$ m, AORI_YK\#3992, SL 8.4 $\mathrm{mm}$, sequenced specimen. F. Thysanobuccinum n. sp., Japan, $38^{\circ} 16^{\prime} \mathrm{N}, 143^{\circ} 32^{\prime} \mathrm{E}, 3302-3311 \mathrm{~m}$, AORI_YK\#3402, SL 20.3 mm, sequenced specimen. G. Beringius crebricostatus (Dall, 1877), Aleutian Is., $54^{\circ} 05^{\prime} \mathrm{N}, 166^{\circ} 23^{\prime} \mathrm{W}, 88 \mathrm{~m}$, RNC_4149, SL $127.7 \mathrm{~mm}$, sequenced specimen. $\mathbf{H}$. Beringius aleuticus Dall, 1895, holotype, Aleutian Is., SE of Seguam I., $52^{\circ} 15^{\prime} \mathrm{N}, 171^{\circ} 40^{\prime} \mathrm{W}, 454$ m, USNM 106999, SL 65 mm. I. Beringius turtoni (Bean, 1834), Iceland, 6700’ $\mathrm{N}, 23^{\circ} 14^{\prime} \mathrm{W}$, 246-247 m, MNHN IM-2013-78021, SL 108.4 mm, sequenced specimen. J. Metajapelion adelphicus (Dall, 1907), Japan, Kyushu Is., 3206'N, 129²9'E, 606-610 m, AORI_YK\#3975, SL $54.1 \mathrm{~mm}$, sequenced specimen (radula, see Fig. 13C). K. Metajapelion pericochlion (Schrenck, 1863), Japan, AORI_YK\#4142, SL $117.7 \mathrm{~mm}$, specimen sequenced for cox-1. L. Neptunea kurosio Oyama, 1959, Japan, Kyushu I., 32010'N, 129³0'E, 470-487 m, AORI_YK\#3985, SL $86.4 \mathrm{~mm}$, sequenced specimen. M. Neptunea fukueae Kira, 1959, Japan, Kyushu I., $32^{\circ} 10^{\prime} \mathrm{N}$, $129^{\circ} 30^{\prime} \mathrm{E}, 470-487 \mathrm{~m}$, AORI_YK\#3658, SL $61.7 \mathrm{~mm}$, sequenced specimen. N. Neptunea despecta (Linnaeus, 1758), Iceland, 67²9' $\mathrm{N}, 21^{\circ} 44,5^{\prime} \mathrm{W}, 755-770 \mathrm{~m}$, MNHN IM-2013-78010, SL $41.2 \mathrm{~mm}$, sequenced specimen. O. Aulacofusus periscelidus (Dall, 1891), Kurile Is., Urup Is., 45 55.2’ N, 150¹5.8'E, 169-150 m, IEE BUC270, SL 58.5 mm, specimen sequenced for cox-1.

Figure 11. Radulae of Buccinidae. A. Neptunea costaria Fraussen \& Terryn, 2007, holotype of Costaria borealis Golikov, 1977, Iturup I. [South Kurile Is.], 414 m, ZIN 30873/1. B. Aulacofusus periscelidus (Dall, 1891), Kurile Is., Urup I., Kitovy Cape, 50 m, ZIN 55945 (after Kosyan \& Kantor, 2013: fig. 5 E). C. Metajapelion adelphicus (Dall, 1907), Japan, Kyushu Is., 32 $06^{\prime} \mathrm{N}, 12^{\circ} 29^{\prime} \mathrm{E}, 606-610$ m, AORI_YK\#3975, SL $54.1 \mathrm{~mm}$ (shell, see Fig. 10 I). D. Japelion hirasei (Pilsbry, 1901), Japan, Honshu I., 39²2'N, $142^{\circ} 15^{\prime} \mathrm{E}, 479-484 \mathrm{~m}$, AORI_YK\#3449, SL 95.8 mm (shell, see Fig. 14F). E. Thalassoplanes moerchi (Dall, 1908), Kurile-Kamchatka Trench, $43^{\circ} 58^{\prime} \mathrm{N}, 157^{\circ} 19^{\prime} \mathrm{E}, 5422-5379$ m, ZSM, uncatalogued (IEE BUC144) (shell, see Fig. 14I). F. Clinopegma magnum unicum (Pilsbry, 1905), form damon, south-eastern Sakhalin, $46^{\circ} 28^{\prime} \mathrm{N}, 142^{\circ} 52^{\prime} \mathrm{E}$, in $44 \mathrm{~m}$, Zoological Museum of Moscow State University, uncatalogued, SL 97.8 mm. G. Anomalisipho virgatus (Friele, 1879), 8057’ N, 
4705'E, Icebraker Litke st. 22, 124 m, ZIN, uncatalogued (shell see Fig, 14K). H. Volutopsius regularis (Dall, 1873) (after Kantor, 1990: fig. 32). I. Parancistrolepis fujitai (Kuroda, 1931) (2) and P. kinoshitai (Kuroda, 1931) (3) (after Habe, 1972).

Scale bars: A, B-E, G - $100 \mu \mathrm{m} ; \mathrm{F}-200 \mu \mathrm{m}$.

Figure 12. Shells of Buccinidae. A. Habevolutopsius hirasei (Pilsbry, 1907), Japan,

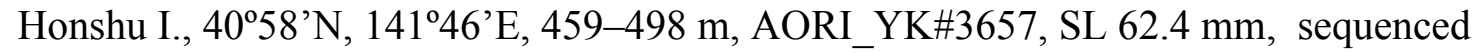
specimen. B. Lussivolutopsius filosus (Dall, 1919), Bering Sea, $60^{\circ} 01^{\prime} \mathrm{N}, 168^{\circ} 39^{\prime} \mathrm{W}, 37 \mathrm{~m}$, RNC_4493, SL $52.8 \mathrm{~mm}$, sequenced specimen. C. Volutopsius fragilis (Dall, 1891), Chukchi Sea, $71^{\circ} 31^{\prime} \mathrm{N}, 157^{\circ} 23^{\prime} \mathrm{W}, 88 \mathrm{~m}, \mathrm{RNC} 4552$, SL $74.2 \mathrm{~mm}$, sequenced specimen. D. Pyrulofusus dexius Dall, 1907, Aleutian Is, 5256'N, 17059'E, $185 \mathrm{~m}$, RNC_4870, SL $148 \mathrm{~mm}$, sequenced specimen. E. Ancistrolepis grammatus (Dall, 1907), Okhotsk Sea, Kurile Is., Onekotan I., $49^{\circ} 31^{\prime} \mathrm{N}, 154^{\circ} 25^{\prime} \mathrm{E}, 571-580 \mathrm{~m}$, IEE Bu-OS-1188, SL $21.4 \mathrm{~mm}$, specimen sequenced for cox-1. F. Japelion hirasei (Pilsbry, 1901), Japan, Honshu I., 39²2'N, $142^{\circ} 15^{\prime} \mathrm{E}, 479-484 \mathrm{~m}$, AORI_YK\#3449, SL 95.8 mm (radula, see Fig. 13D). G. Clinopegma magnum unicum (Pilsbry, 1905), Japan, Honshu I., 38 25'N, 14200'E, 342-343 m, AORI_YK\#3403, SL 75.7 mm, sequenced specimen. H. Bathyancistrolepis trochoideus (Dall, 1907), Japan, Honshu I., $38^{\circ} 47^{\prime} \mathrm{N}, 143^{\circ} 10^{\prime} \mathrm{E}, 1887-1919 \mathrm{~m}$, AORI_YK\#3377, SL $38.4 \mathrm{~mm}$, sequenced specimen. I.

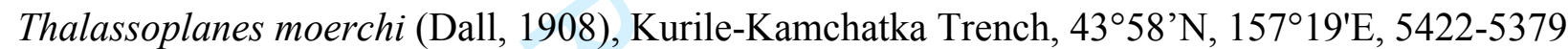
m, ZSM, uncataloged (IEE BUC144), SL $31.4 \mathrm{~mm}$, sequenced specimen (radula, see Fig. 13E). J. Pseudoliomesus canaliculatus (Dall, 1874), Japan, AORI_YK\#4141, SL 32.2 mm, specimen sequenced for cox-1. K. Parancistrolepis fujitai (Kuroda, 1931), Japan, AORI_YK\#3401, SL $81.4 \mathrm{~mm}$, specimen sequenced for cox-1. L. Anomalisipho virgatus (Friele, 1879), Spitzbergen, $80^{\circ} 57^{\prime} \mathrm{N}, 4^{\circ} 05^{\prime} \mathrm{E}$, Icebraker Litke st. 22, $124 \mathrm{~m}$, ZIN, uncatalogued, SL $40.3 \mathrm{~mm}$ (radula, see Fig. 13G). M. Anomalisipho verkruzeni (Kobelt, 1876), Iceland, 6706'N, 23ำ' $14^{\prime} \mathrm{W}, 246 \mathrm{~m}$, MNHN IM-2013-78020, SL 61.5 mm, sequenced specimen. N. Plicifusus rhyssus (Dall, 1907), Japan, AORI_YK\#4211, SL 46.7 mm, specimen sequenced for cox-1. O. “Colus” kujianus Tiba, 1973, Japan, AORI_YK\#4210, SL 57.7 mm, specimen sequenced for cox-1. P. Liomesus ovum (Turton, 1825), Scotland, SL $29.1 \mathrm{~mm}$ C Guido \& Philippe Poppe - www.conchology.be. Q. Truncaria filosa (A. Adams \& Reeve, 1850) (holotype of Cominella brunneocincta Dall, 1896), Albatross st. 3390, Gulf of Panama, 102 m, USNM 123009, SL 31.5 mm (photo USNM).

Figure 13. Shells of Siphonaliidae. A. Pararetifusus tenuis (Okutani, 1966), off Kesennuma, Miyagi, Honshu I., Japan, 3847’N, 143ํ'10’E, 1887-1919 m, SL 11.6 mm, sequenced spm (BUC 181). B. Bayerius holoserica (Lus, 1971), KURAMBIO I st. AGT 6-9,

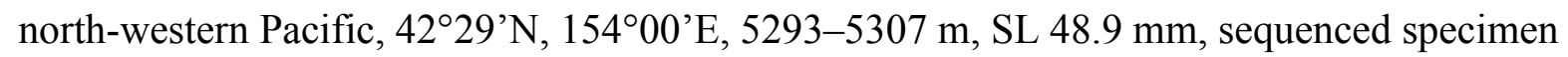
(radula, see Fig. 11A). C. Bayerius knudseni (Bouchet \& Warén, 1986). KURAMBIO I st. AGT 12-5, north-western Pacific, 3944’N, 147¹0'E, 5229-5217 m, SL 23.9 mm, sequenced specimen (radula, see Fig.11B). D. Phaenomenella insulapratasensis (Okutani \& Lan, 1994), South China Sea, DONGSHA 2014 st. CP4129, 20²9'N, 116²'E, 590-633 mm, MNHN IM2013-50203, SL 38.7 mm, sequenced specimen. E. Phaenomenella nicoi Kantor, Kosyan, Sorokin \& Fedosov, 2020, holotype, South China Sea, SW off Dong Sha, ZHONGSHA 2015; st. CP4132, 2007'N, 116²2'E, 958-988 m, MNHN IM-2013-61585, SL $41.1 \mathrm{~mm}$, sequenced specimen (radula, see Fig. 11D). F. Siphonalia spadicea (Reeve, 1847), South China Sea,

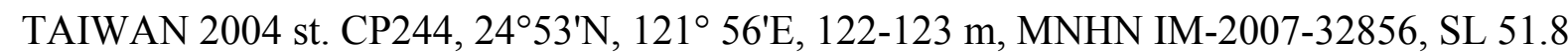


mm, sequenced specimen. G. Mohnia dalli (Friele, 1881), Barents Sea, $72^{\circ} 23^{\prime} \mathrm{N}, 14^{\circ} 58^{\prime} \mathrm{E}, 702$ $\mathrm{m}, \mathrm{SL} 24.6 \mathrm{~mm}$, sequenced specimen.

Figure 14. Radulae of Siphonaliidae. A. Bayerius holoserica (Lus, 1971), KURAMBIO I st. AGT 6-9, north-western Pacific, 42²9’N, 15400’E, 5293-5307 m (shell, see Fig. 10B). B. Bayerius knudseni (Bouchet \& Warén, 1986). KURAMBIO I st. AGT 12-5, north-western

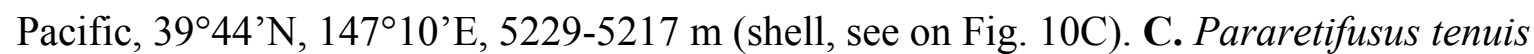
(Okutani, 1966), Kurile Is., off Iturup I., 44²0’N, 148²4’E, 414 m, ZIN 58795/6 (after Kosyan, 2006, fig. 3A). D-E. Phaenomenella nicoi Kantor, Kosyan, Sorokin \& Fedosov, 2020, D holotype, South China Sea, SW off Dong Sha, ZHONGSHA 2015 st. CP4132, 2007’ N, $116^{\circ} 22^{\prime}$ E, 958-988 m, MNHN IM-2013-61585 (shell, see Fig. 10E); E - South China Sea, ZHONGSHA 2015 st. CP4134, 1950’N, 116²7’E, 1128-1278 m, MNHN-IM-2013-61673. F. Siphonalia cassidariaeformis (Reeve, 1846), Japan, Off Hashima, Miyazaki Prefecture, Kyushu (after Kantor et al., 2020a: fig. 11A).

Scale bars: A,B, D, E - $100 \mu \mathrm{m}, \mathrm{C}-50 \mu \mathrm{m}, \mathrm{F}-200 \mu \mathrm{m}$.

Figure 15. Shells of Busyconidae (A-C), Buccinanopsidae (D), Cominellidae (E-J), and Retimohniidae (K-O). A. Busycotypus canaliculatus (Linnaeus, 1758), USA, South Carolina, MNHN IM-2013-40689, sequenced specimen. B. Busycon carica (Gmelin, 1791), USA, South Carolina, MNHN IM-2013-40690, sequenced specimen. C. Fulguropsis pyruloides (Say, 1822), USA, South Carolina, MNHN IM-2013-40692, sequenced specimen. D. Buccinanops deformis (P. P. King, 1832), Argentina, Isla de los Pajaros, $42^{\circ} 25.4^{\prime} \mathrm{S}, 64^{\circ} 32.2^{\prime} \mathrm{W}$, intertidal, IEE uncatalogued, SL 27.7 mm (radula, see Fig. 16I). E. Pareuthria fuscata (Bruguière, 1789), Tierra del Fuego, San Sebastian Bay, 53⒗8'S, 68¹3.2'W, USNM 898376, SL 21.6 mm (photo

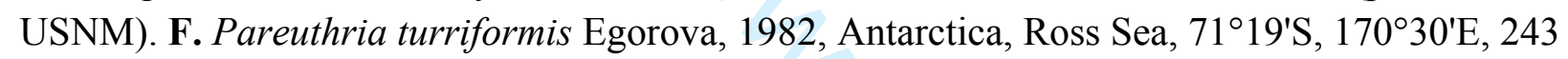
m, MNA168, SL $16.1 \mathrm{~mm}$, sequenced specimen. G. Cominella virgata H. Adams \& A.Adams, 1853, New Zealand, Ahipara Bay, Reef Point, Te Papa Tongareva (M.278752), SL 31.3 mm. H. Cominella glandiformis (Reeve, 1847), New Zealand, Mangere Inlet, SE of Auckland, 3656'S, 174ํํ'E, AORI_YK\#3987, 25.6 mm, sequenced specimen. I. Lusitromina abyssorum (Lus, 1993), off Saunders I., South Sandwich Is., 57³9'S, 2600'W, 2380-2609 m, USNM 1010536, SL 29.2 mm (photo USNM) (radula, see Fig. 16E). J. Falsitromina bella (Powell, 1951), South Shetland Is., $61^{\circ} 45^{\prime} \mathrm{S}, 61^{\circ} 14^{\prime} \mathrm{W}, 4758 \mathrm{~m}$, USNM 881870, SL $5.1 \mathrm{~mm}$. K. Retimohnia bella

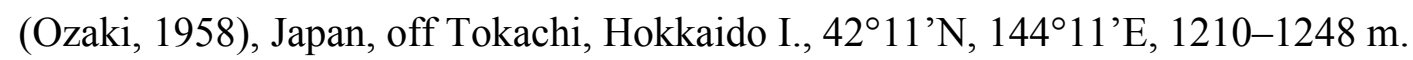

AORI_YK\#3977, SL 24.5 mm, sequenced specimen. L. Retimohnia micra (Dall, 1907), Japan, off Otsuchi, Iwate, Honshu I., 39²0’N, 142²3’E, 849-864 m, AORI_YK\#3978, SL 11.7 mm, sequenced specimen. M. Fusipagoda exquisita (Dall, 1913), Eastern Kamchatka, 5552’N, $164^{\circ} 8^{\prime} \mathrm{E}, 4382 \mathrm{~m}, \mathrm{R} / \mathrm{V}$ Vityaz sta. 524, SL 23.5 mm (radula, see Fig. 16G) (after Kosyan \& Kantor, 2015: fig. 1B). N. Fusipagoda sp., Japan, off Onagawa, Miyagi, Honshu I., $38^{\circ} 16^{\prime}$ N, $143^{\circ} 32^{\prime} \mathrm{E}, 3302-3311 \mathrm{~m}$, AORI_YK\#3981, SL $29.1 \mathrm{~mm}$, sequenced specimen. O. Retifusus jessoensis (Schrenck, 1863), Sea of Japan, Peter the Great Bay, ZIN 34121/16, SL $22.1 \mathrm{~mm}$ (radula, see Fig. 16H) (after Kosyan \& Kantor, 2014: fig. 1B).

Figure 16. Radulae of Busyconidae (A-B), Cominellidae (C-E), Retimohniidae (F-H), Buccinanopsidae (I), and Buccinoidea insertae sedis (J-K). A. Busycon carica (Gmelin, 1791), USA, Lewes, Delaware (after Kosyan \& Kantor, 2004: fig. 11A). B. Fulguropsis spirata 
1 (Lamarck, 1816), Mexico, Yucatan (after Kosyan \& Kantor, 2004: fig. 11C). C. Pareuthria fuscata (Bruguière, 1789) (after Pastorino, 2016; photo G. Pastorino). D. Cominella virgata $\mathrm{H}$. Adams \& A.Adams, 1853, New Zealand,Wellington Bay, New Zealand (after Cernohorsky, 1971: fig. 93). E. Lusitromina abyssorum (Lus, 1993), off Saunders I., South Sandwich Is., 57³9'S, 2600'W, 2380-2609 m, SL 29.2 mm, USNM 1010536 (shell, see Fig 15I). F. Retimohnia micra (Dall, 1907), Sea of Japan, R/V Vityaz st. 7490, 3951'N, 1334ㄱ'E, $560 \mathrm{~m}$ (after Kosyan \& Kantor, 2016: fig. 9B). G. Fusipagoda exquisita (Dall, 1913), eastern

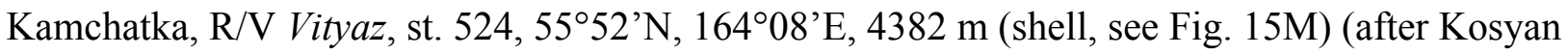
\& Kantor, 2015: fig. 3A). H. Retifusus jessoensis (Schrenck, 1863 in 1862-63), Sea of Japan, Peter the Great Bay, ZIN 34121/16, SL $22.1 \mathrm{~mm}$ (shell, see Fig. 15O) (after Kosyan \& Kantor, 2014: fig. 4A). I. Buccinanops deformis (P. P. King, 1832), Argentina, Isla de los Pajaros, 42 $25.4^{\prime}$ 'S, 64³2.2’W, intertidal, IEE uncatalogued (shell, see Fig. 15D). J. Macron spp. - (350) M. lividus (A.Adams, 1855); (352) Macron aethiops (Reeve, 1847) (after Thiele, 1929). K. Burnupena spp - (b) B. cincta (Röding, 1798); (d) Burnupena papyracea (Bruguière, 1789) (after Orr, 1956: fig. 1).

Scale bars: A,B $-500 \mu \mathrm{m} ; \mathrm{C}-80 \mu \mathrm{m} . \mathrm{E}, \mathrm{F}, \mathrm{G}, \mathrm{H}, \mathrm{I}-100 \mu \mathrm{m}$.

Figure 17. Shells of Austrosiphonidae (A-E) and Tudiclidae (F-P). A. Penion cuvierianus (Powell, 1927), New Zealand, off White I., NMNZ M.132414. B. Penion chathamensis Powell, 1938, New Zealand, E of Mernoo Bank, Chatham Rise, NMNZ M.118863. C. Antarctoneptunea benthicola (Dell, 1956), New Zealand, Chatham Rise, NMNZ M.009775, SL 95 mm. D.

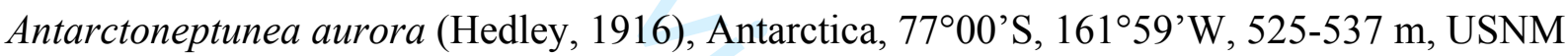
898682, SL 68.9 mm (photo USNM). E. Serratifusus lineatus Harasewych, 1991, holotype, New Caledonia, Grand Passage, 1855'S, 163²4'E, 460 m, MNHN IM-2000-6527, SL 35.5 mm. F. Aeneator recens (Dell, 1951), New Zealand, NE slope of Mernoo Bank, Chatham Rise, NMNZ M.127027. G. Aeneator benthicolus Dell, 1963, New Zealand, off Cape Kidnappers, NMNZ M.147010. H. Buccinulum linea (Martyn, 1784), neotype, New Zealand, head of Titirangi Bay, NE of Havelock, NMNZ M.046477, SL 35.4 mm. I. Euthria walleri (Ladd, 1976), Vanuatu, $15^{\circ} 33^{\prime} \mathrm{S}, 167^{\circ} 17^{\prime} \mathrm{E}, 120-156 \mathrm{~m}$, MNHN IM-2007-32887, SL $57.5 \mathrm{~mm}$, sequenced specimen. J. Tasmeuthria clarkei (Tenison Woods, 1876), Western Australia, Esperance, Woody I., 3358'S, $122^{\circ} 01^{\prime} \mathrm{E}, 11 \mathrm{~m}, \mathrm{MNHN}$ IM-2013-63028, SL $9.9 \mathrm{~mm}$, sequenced specimen (radula, see Fig. 18K). K. Afer cumingii (Reeve, 1848), Taiwan, SL 88.9 mm, (C) Guido \& Philippe Poppe www.conchology.be. L. Euthria japonica (Shuto, 1978), E Taiwan, 2434'N, 122²'E, 195-207 m, IM-2013-78127, sequenced specimen (radula, see Fig. 18J). M. Euthria cummulata Fraussen

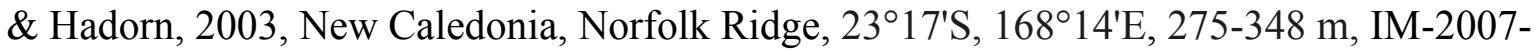
34931, SL 46.2 mm, sequenced specimen. N. Euthriostoma saharicum (Locard, 1897), Western Sahara, (C) Guido \& Philippe Poppe - www.conchology.be. O. Tudicla spirillus (Linnaeus, 1767), trawled between Porto Novo and Pondicherry, India, 13-15 m, USNM 894130, SL 76.7 mm (after Harasewych, 2018). P. Lirabuccinum dirum (Reeve, 1846), USA, SL 26 mm, (C) Guido \& Philippe Poppe - www.conchology.be.

Figure 18. Radulae of Austrosiphonidae (A-F) and Tudiclidae (G-P). A. Antarctoneptunea aurora (Hedley, 1916), Antarctica, Adélie Land, 66³4'S, 145²1'E, 401-416 m, MNHN IM2009-7893. B. Antarctoneptunea benthicola (Dell, 1956), New Zealand, 48 $49^{\prime}$ 'S, $167^{\circ} 27^{\prime} \mathrm{E}, 560$ m, MNNZ M.95190. C. Antarctoneptunea benthicola (Dell, 1956), New Zealand, 4303.7’S, 
17700’E, 350 m, MNNZ M.117007. D. Kelletia lischkei Kuroda, 1938 (after Kang, 1976). E. Penion cuvierianus (Powell, 1927), New Zealand, Peach Cove, Bream Bay, Northland, 35'51.9'S, 174³4.1'E, 24 m, NMNZ M.98018. F. Serratifusus lineatus Harasewych, 1991, northern New Caledonia, 1859'S, 163²4'E, 320-335 m, MNHN IM-2007-34666 (sequenced specimen). G. Aeneator spp. (A) Aeneator elegans (Suter, 1917), st. VUZ83, off Palliser Bay, 1000 m, NMNZ M.11115; (B) A. valedictus (R. B. Watson, 1886), Chatham Islands Expedition st. 6, Chatham Rise, 400 m, NMNZ (after Beu, 1979). H. Buccinulum linea (Martyn, 1784), New Zealand, NMNZ. I. Euthria cornea (Linnaeus, 1758), Mediterranean, Capri I., IEE uncatalogued. J. Euthria japonica (Shuto, 1978), E Taiwan, $24^{\circ} 34^{\prime} \mathrm{N}, 122^{\circ} 02^{\prime} \mathrm{E}, 195-207 \mathrm{~m}$, IM2013-78127 (shell, see Fig. 17L). K. Tasmeuthria clarkei (Tenison Woods, 1876), Western Australia, Esperance, Woody I., 335' ${ }^{\circ}$, $122^{\circ} 01^{\prime} \mathrm{E}, 11 \mathrm{~m}, \mathrm{MNHN}$ IM-2013-63028 (shell, see Fig. 17J). L. Afer cumingii (Reeve, 1848) (after Li et al., 2013: fig. 2).

Scale bars: A,B,H-J - $100 \mu \mathrm{m}$; C, E, K - $250 \mu \mathrm{m} ; \mathrm{F}-50 \mu \mathrm{m}$

Figure 19. Shells of Prodotiidae fam. nov. (A-I). A. Clivipolia pulchra (Reeve, 1846), Philippines, Pamilacan I., 09²9.4'N, 1235⒍0'E, 17 m, MNHN IM-2007-32529, SL 22.4 mm, sequenced specimen. B. Caducifer decapitatus (Reeve, 1844), Vanuatu, 15³3.0'S, $167^{\circ} 09.6^{\prime} \mathrm{E}$, 20 m, MNHN IM-2007-32728, SL 13 mm, sequenced specimen. C. Caducifer decapitatus (Reeve, 1844), Papua-New Guinea, Madang lagoon, S Sek I., 0506.4'S, 14549'21.2"E, MNHN IM-2013-18102, SL $8.3 \mathrm{~mm}$ (young specimen with intact spire). D-E. Prodotia lannumi (Schwengel, 1950), Vanuatu, Santo, south of Aoré I., $15^{\circ} 36.6$ 'S, $167^{\circ} 10.0^{\prime} \mathrm{E}, 10-18 \mathrm{~m}$, D MNHN IM-2007-32839, SL 11.6 mm, sequenced specimen; E - MNHN IM-2007-32859, SL $14.1 \mathrm{~mm}$. F. Enzinopsis contracta Reeve, 1846 (holotype of Engina gannita Hedley, 1914), Australia, Queensland, Torres Strait, Darnley I., AMS C.7468, SL 17.2 mm. G. Speccapollia africana Fraussen \& Stahlschmidt, 2016, holotype, Mozambique, Nacala Bay, 3-5 m, MNHN IM- 2000-31691, SL 10 mm. H. Minioniella heleneae Fraussen \& Stahlschmidt, 2016, holotype, Tuamotu Islands, IM- 2000-31692, SL 6.7 mm. I. Prodotia iostoma (Gray, 1833), New Caledonia, Koumac, KOUMAC 2.3 st. KB617, 2044,7'S, 164²15,8'E, 13 m, SL 22.1 mm (radula, see Fig. 20D).

Figure 20. Radulae of Melongenidae (A), Chauvetiidae fam. nov. (B) and Prodotiidae fam. nov. (C-F) A. Volegalea cochlidium (Linnaeus, 1758), Vietnam, Haiphong, fishermen market (after Kosyan \& Kantor. 2004: fig. 3C, as Pugilina pugilina (Born, 1778)). B. Chauvetia mamillata (Risso, 1826) (after Gofas \& Oliver, 2010: fig. 2). C. Prodotia lannumi (Schwengel, 1950), New Ireland, Kavieng. D. Prodotia iostoma (Gray, 1833), New Caledonia, Koumac, KOUMAC 2.3 st. KB617, 2044.7'S, $164^{\circ} 15.8^{\prime} \mathrm{E}, 13 \mathrm{~m}$ (shell, see Fig. 19I). E. Clivipollia pulchra (Reeve, 1846), New Caledonia, Grand récif de Koumac, KOUMAC 2.3 st. KL39, $20^{\circ} 45.1^{\prime} \mathrm{S}, 164^{\circ} 14.0^{\prime} \mathrm{E}, 26 \mathrm{~m}, \mathrm{MNHN}$ IM-2019-8415. F. Caducifer decapitatus (Reeve, 1844), New Caledonia, Grand récif de Koumac, KOUMAC 2.3 st. KB645, 2040.5'S, $164^{\circ} 13.0^{\prime} \mathrm{E}, 16$ m, MNHN IM-2019-9119.

Scale bars: A - $100 \mu \mathrm{m}, \mathrm{B}-10 \mu \mathrm{m} ; \mathrm{C}-20 \mu \mathrm{m}$; D, E, F - $50 \mu \mathrm{m}$

Figure 21. Shells of Pisaniidae (A-N) and Chauvetiidae fam, nov. (O-P). A. "Engina" egregia (Reeve, 1844), Vanuatu, Santo, SE Aesi I., 15²6.9'S, 167¹5.8'E, 11 m, IM-200732918, SL 14 mm, sequenced specimen. B. Engina mendicaria (Linnaeus, 1758), Vanuatu, S 
coast of Santo I., $15^{\circ} 34.9^{\prime} \mathrm{S}, 167^{\circ} 02.4^{\prime} \mathrm{E}, 0-1 \mathrm{~m}$, MNHN IM-2007-32893, SL $15.9 \mathrm{~mm}$. C. Engina alveolata (Kiener, 1836), Vanuatu, Santo, E. of Malo I., 15²43.4'S, 167 $15.0^{\prime} \mathrm{E}, 6 \mathrm{~m}$, MNHN IM2007-32919, SL 12.4 mm, sequenced specimen. D. Hesperisternia karinae (Nowell-Usticke, 1959), Guadeloupe, $16^{\circ} 24^{\prime} \mathrm{N}, 60^{\circ} 52^{\prime} \mathrm{W}, 72-111 \mathrm{~m}$, MNHN IM-2013-60604, sequenced specimen. E. “Engina” corinnae Crovo, 1971, Martinique, Ste Luce, Grand Caye, 14²7.3'N, 60 55.5'W, 15 m, MNHN IM-2013-70604, SL $9.3 \mathrm{~mm}$, sequenced specimen. F. Pisania striata (Gmelin, 1791), Greece, SL 16.5 mm, (C) Guido \& Philippe Poppe - www.conchology.be. G. "Pisania" pusio (Linnaeus, 1758), Guadeloupe, SL $34.2 \mathrm{~mm}$, (C) Guido \& Philippe Poppe www.conchology.be. H. "Pisania" decollata (G.B. Sowerby I, 1833), Papua New Guinea, $05^{\circ} 11^{\prime} \mathrm{S}, 145^{\circ} 50^{\prime} \mathrm{E}, 5 \mathrm{~m}$, MNHN IM-2013-18270, SL $20.7 \mathrm{~mm}$, sequenced specimen. I. “Pisania" ignea (Gmelin, 1791), N Madagascar, 2517'S, 4631'E, 53-54 m, MNHN IM-200914631, sequenced specimen. J. Gemophos tinctus (Conrad, 1846), Guadeloupe, $16^{\circ} 20^{\prime} \mathrm{N}$, $61^{\circ} 32^{\prime} \mathrm{W}, 1 \mathrm{~m}, \mathrm{MNHN}$ IM-2013-8012, SL $16.4 \mathrm{~mm}$, sequenced specimen. K. Cancellopollia gracilis Vermeij \& Bouchet, 1998, holotype, New Caledonia, Norfolk Ridge, 435 m, MNHN IM-2000-6329, SL $29.8 \mathrm{~mm}$. L. Pollia fumosa (Dillwyn, 1817), South Madagascar, 2528.1'S, 44⒌ 56.'E, 12-14 m, MNHN IM-2009-14575. M. Cantharus melanostoma (G.B. Sowerby I, 1825), Philippines, SL $59.2 \mathrm{~mm} \odot$ Guido \& Philippe Poppe - www.conchology.be. N. Pollia imprimelata Fraussen \& Rosado, 2011, South Madagascar, 242ㄱ' $3^{\prime} \mathrm{S}, 47^{\circ} 32^{\prime} \mathrm{E}, 154-168 \mathrm{~m}$, IM2009-14603, sequenced specimen. O. Chauvetia mamillata (Risso, 1826), Spain, Malaga, 0-5 m, IEE BUC 193, SL 5.5 mm. P. Chauvetia procerula (Monterosato, 1889), Spain, Malaga, 0-5 m, IEE BUC 210, SL $4.2 \mathrm{~mm}$

Figure 22. Radulae of Pisaniidae. A. Pisania striata (Gmelin, 1791), Mediterranean (after Troschel, 1867, pl. 7, fig. 2). B. "Pisania" decollata (G.B. Sowerby I, 1833), New Caledonia, Koumac, MNHN unregistered. C. "Pisania" fasciculata (Reeve, 1846), New Caledonia,

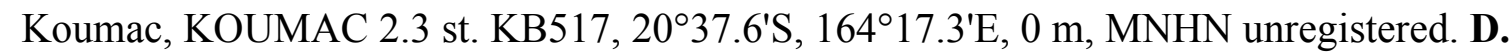
"Pisania" (= Ecmanis) ignea (Gmelin, 1791) (after Ponder, 1972: text fig. 2). E. Engina turbinella (Kiener, 1836), French Guiana, $05^{\circ} 17.5^{\prime} \mathrm{N}, 52^{\circ} 35.2^{\prime} \mathrm{W}, 7 \mathrm{~m}$, MNHN IM-2013-57184 (sequenced specimen). F. Engina mendicaria (Linnaeus, 1758), Papua New Guinea, Laing I., IEE unregistered. G. Pollia fumosa (Dillwyn, 1817), Vietnam, Nha-Trang Bay, Mun I., IEE unregistered. H. Pollia undosa (Linnaeus, 1758), Vietnam, Nha-Trang Bay, Mun I., IEE unregistered. I. "Engina" egregia (Reeve, 1844), Papua New Guinea, Madang Lagoon, $05^{\circ} 13.8^{\prime} \mathrm{S}, 145^{\circ} 48.0^{\prime} \mathrm{E}, 15 \mathrm{~m}, \mathrm{MNHN}$ IM-2013-12540.

Scale bars: B, C, G, H $-100 \mu \mathrm{m}$; E, F $-20 \mu \mathrm{m}, \mathrm{I}-50 \mu \mathrm{m}$.

Figure 23. Shells of Nassariidae. Cylleninae: A. Cyllene owenii Gray, 1834 (syntype of Cyllene senegalensis Petit de la Saussaye, 1853), Senegal, MNHN IM-2000-6364, SL 16 mm. B. Cyllene parvula Bozzetti, 2014, Madagascar, holotype, MNHN IM-2000-27891, SL 12.5 mm. C. Neoteron ariel (Pilsbry \& Lowe, 1932), holotype, ANSP 155564, Nicaragua, SL $6.5 \mathrm{~mm}$ (photo ANSP). Tomliniinae: D. Nassaria acuminata (G.B. Sowerby III, 1913), Vanuatu, $15^{\circ} 37^{\prime}$ S, 167 $15^{\prime} \mathrm{E}, 140-153 \mathrm{~mm}$, MNHN IM-2007-32730, SL $23.6 \mathrm{~mm}$, sequenced specimen. E. Tomlinia frausseni Thach, 2014, Vietnam, MNHN IM-2013-53362. Bulliinae: F. Bullia perlucida Bozzetti, 2014, holotype, Madagascar, MNHN IM-2000-27493, SL 19.9 mm. Dorsaninae: G. Dorsanum miran (Bruguière, 1789), Senegal, SL 22.5 mm, (C) Guido \& Philippe Poppe www.conchology.be. Anentominae: H. Oligohalinophila dorri (Wattebled, 1886), syntype, MNHN IM-2000-6321, Vietnam, lagune de Koa-hai, SL 13.9 mm. I. Anentome sp. D, Vietnam, 
1 vicinities of Nha-Trang city, middle part of Kai river, IM-2009-29658, sequenced specimen. 2 Nassariinae: J. Naytia glabrata (G.B. Sowerby II, 1842), Cameroon, SL 7.2 mm, (C) Guido \& 3 Philippe Poppe - www.conchology.be. K. Phrontis complanata (Powys, 1835), Costa Rica, SL $47.1 \mathrm{~mm}$, (C) Guido \& Philippe Poppe -www.conchology.be. Photinae: L. Engoniophos unicinctus 5 (Say, 1826) (syntype of Nassa guadelupensis Petit de la Saussaye, 1852), Guadeloupe, MNHN 6 IM-2000-6713, SL $27.1 \mathrm{~mm}$. M. Antillophos candeanus (d'Orbigny, 1842) (syntype of Phos 7 antillarum Petit de la Saussaye, 1853), Guadeloupe, MNHN IM-2000-6584, SL 28.5 mm. N. 8 Phos senticosus (Linnaeus, 1758), Papua New Guinea, Laing I., intertidal, SL $33.5 \mathrm{~mm}$ (radula, 9 see Fig. 24G). O. Northia pristis (Deshayes, 1844), Panama, Venado I., intertidal, IEE BUC 10 YK1 (radula, see Fig. 24F).

Figure 24. Radulae of Nassariidae. A. Tomlinia frausseni Thach, 2014, Vietnam, MNHN. B. Nassaria sp., Bismarck Sea, W Kairiru I., 03ํำ'S, $143^{\circ} 28^{\prime} \mathrm{E}, 325-345$ m, PAPUA NIUGINI st. CP4048, MNHN IM-2013-18779. C. Anentome sp. D, Vietnam, vicinities of Nha-Trang city, middle part of Kai river, MNHN IM-2009-29661. D. Oligohalinophila dorri (Wattebled, 1886), Vietnam (after Kantor \& Kilburn, 2001: fig. 18). E. Tritia reticulata (Linnaeus, 1758), Black 18 Sea, Gelendzhik, IEE uncatalogued. F. Northia pristis (Deshayes, 1844), Panama, Venado I., intertidal, IEE BUC YK1 (shell, see Fig. 21M). G. Phos senticosus (Linnaeus, 1758), PapuaNew Guinea, Laing Id., intertidal, IEE uncatalogued, SL $33.5 \mathrm{~mm}$ (shell, see Fig. 21L). H. Engoniophos unicinctus (Say, 1826) (after Abbate et al., 2018: fig. 5). I. Radulae of Nassariidae, Cylleninae. Upper panel - Cyllene fuscata A.Adams, 1851 (after Yang \& Zang, 2011: pl. 1r).

23 lower panel - Neoteron ariel (Pilsbry \& Lowe, 1932), after D’Attilio (1981). Scale bars: A-E, G, $24 \mathrm{I}-100 \mu \mathrm{m}, \mathrm{F}-200 \mu \mathrm{m}$. 
1

Table 1. Comparison of previous classifications of Buccinoidea with the classification accepted in the present paper.

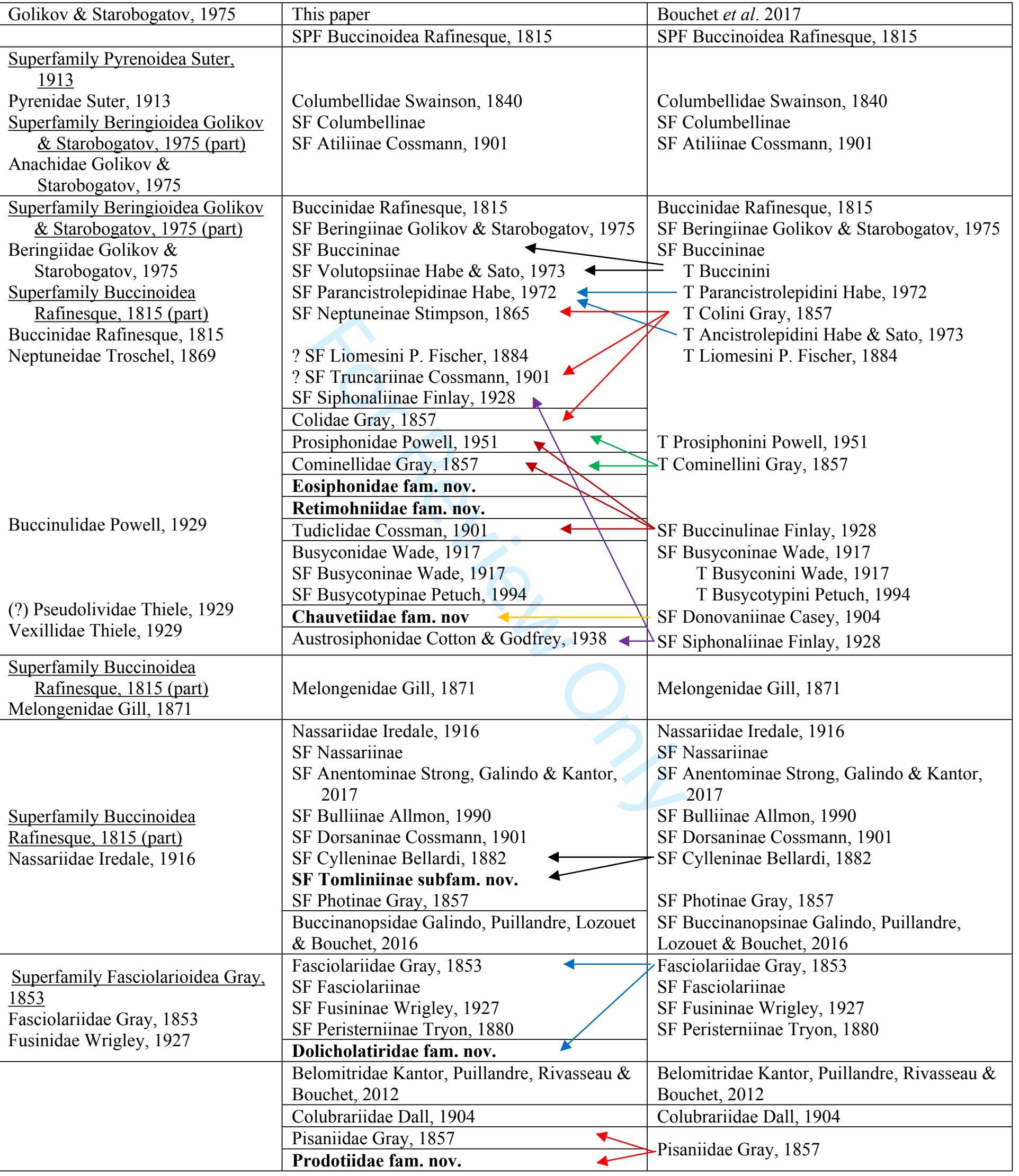




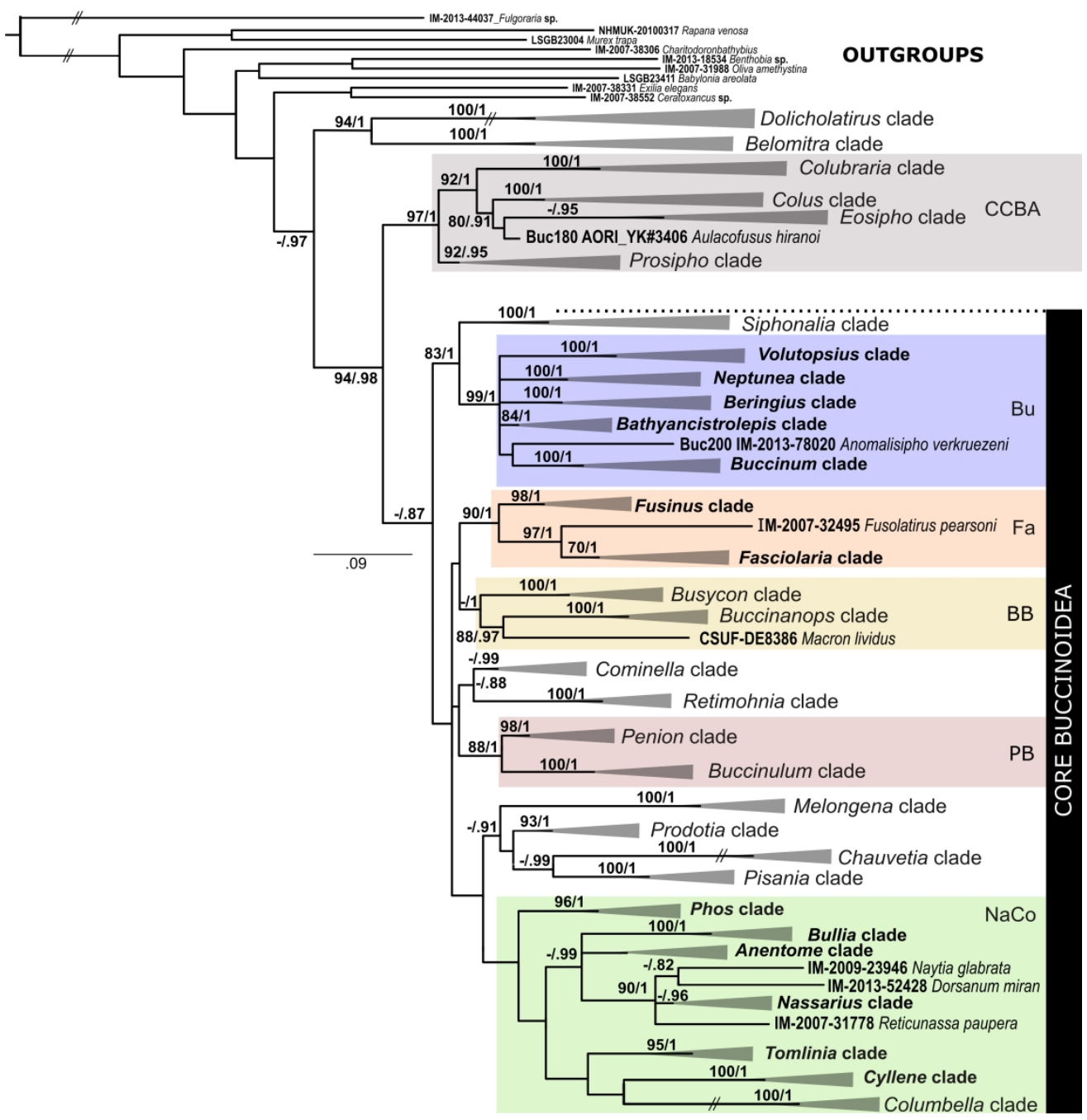

Figure 1. Buccinoidea phylogenetic relationships obtained with the the Bayesian Inference (BI) of the multigene Buc5G dataset (concatenated alignment cox1, 12S, 16S, 28S and H3 genes). Bootstrap values (B $>70 \%)$ and posterior probabilities (PP $\geq 0.95$ ) are shown above each nodes. The clades containing multiple samples are collapsed.

$170 \times 174 \mathrm{~mm}(599 \times 599 \mathrm{DPI})$ 


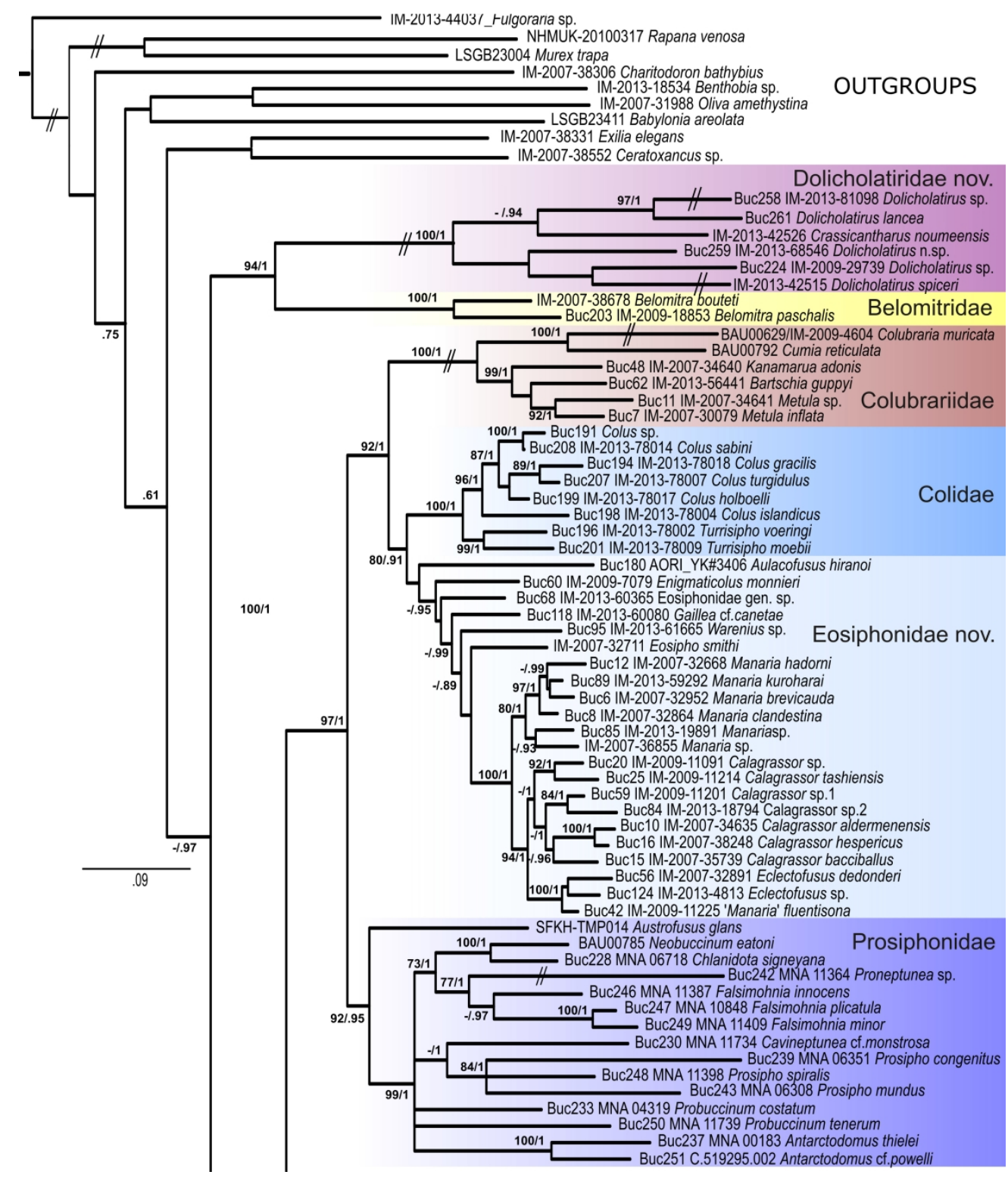

Figure 2 (3 parts). Buccinoidea phylogenetic relationships obtained with the Maximum Likelihood (ML) and the Bayesian Inference (BI) of the multigene dataset (concatenated alignment cox1, 12S, 16S, 28S and H3 genes). Bootstrap values $(B>70 \%)$ and posterior probabilities $(P P \geq 0.95)$ are shown above each nodes. The names of the family group taxa are provided according to the classification accepted in the present work. 


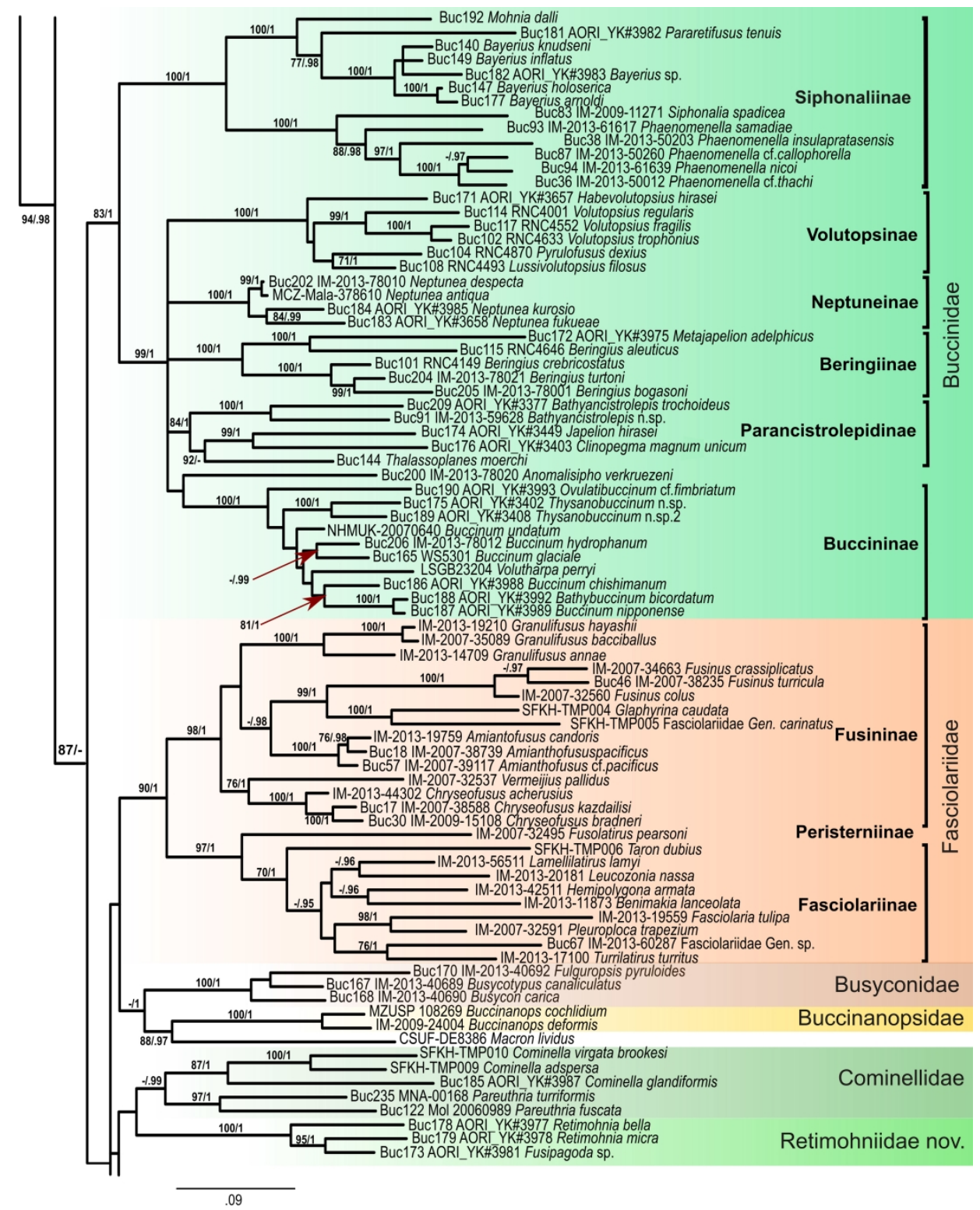

Figure 2 continued

$170 \times 215 \mathrm{~mm}(600 \times 600 \mathrm{DPI})$ 


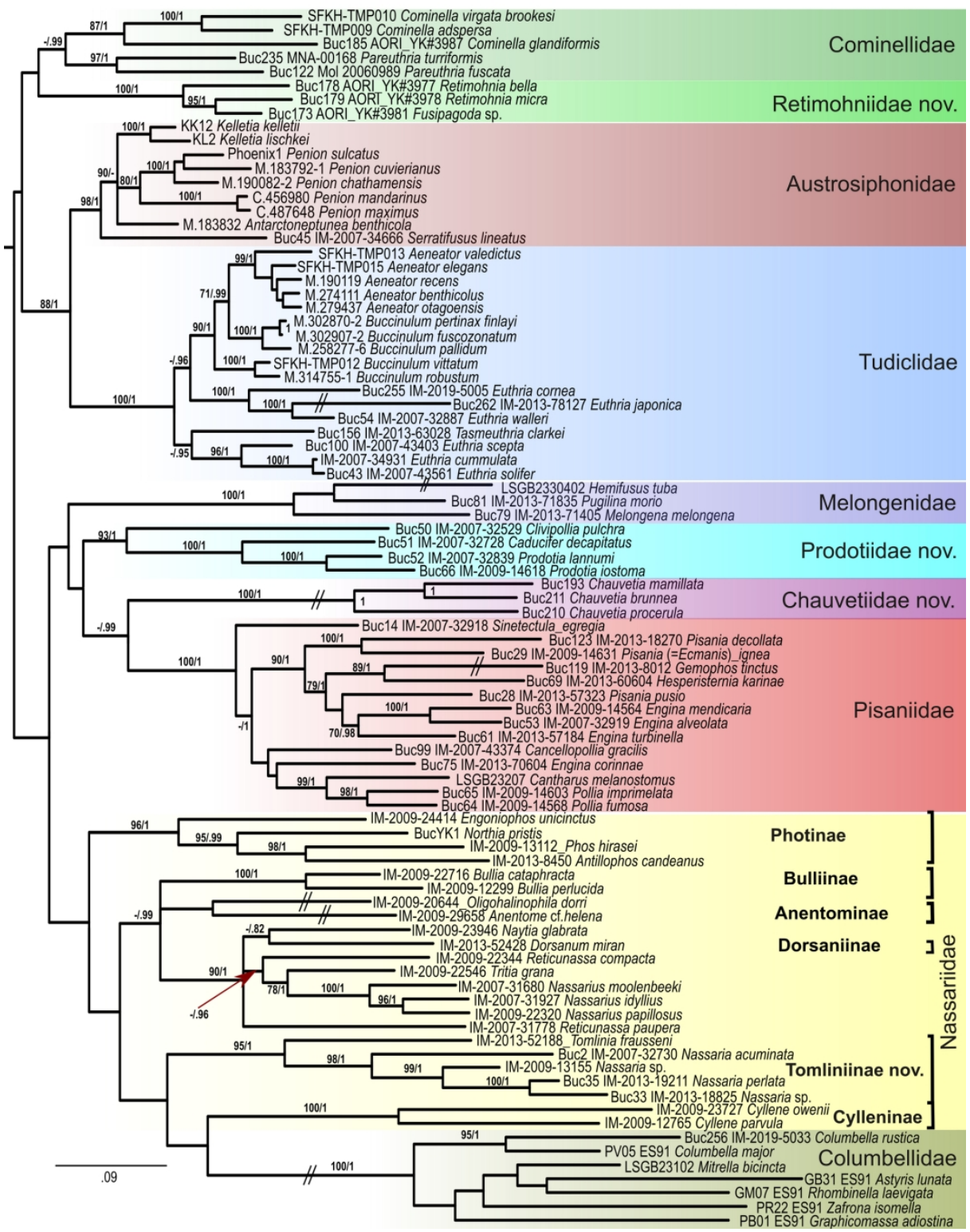

Figure 2 (completed)

$170 \times 219 \mathrm{~mm}(300 \times 300 \mathrm{DPI})$ 


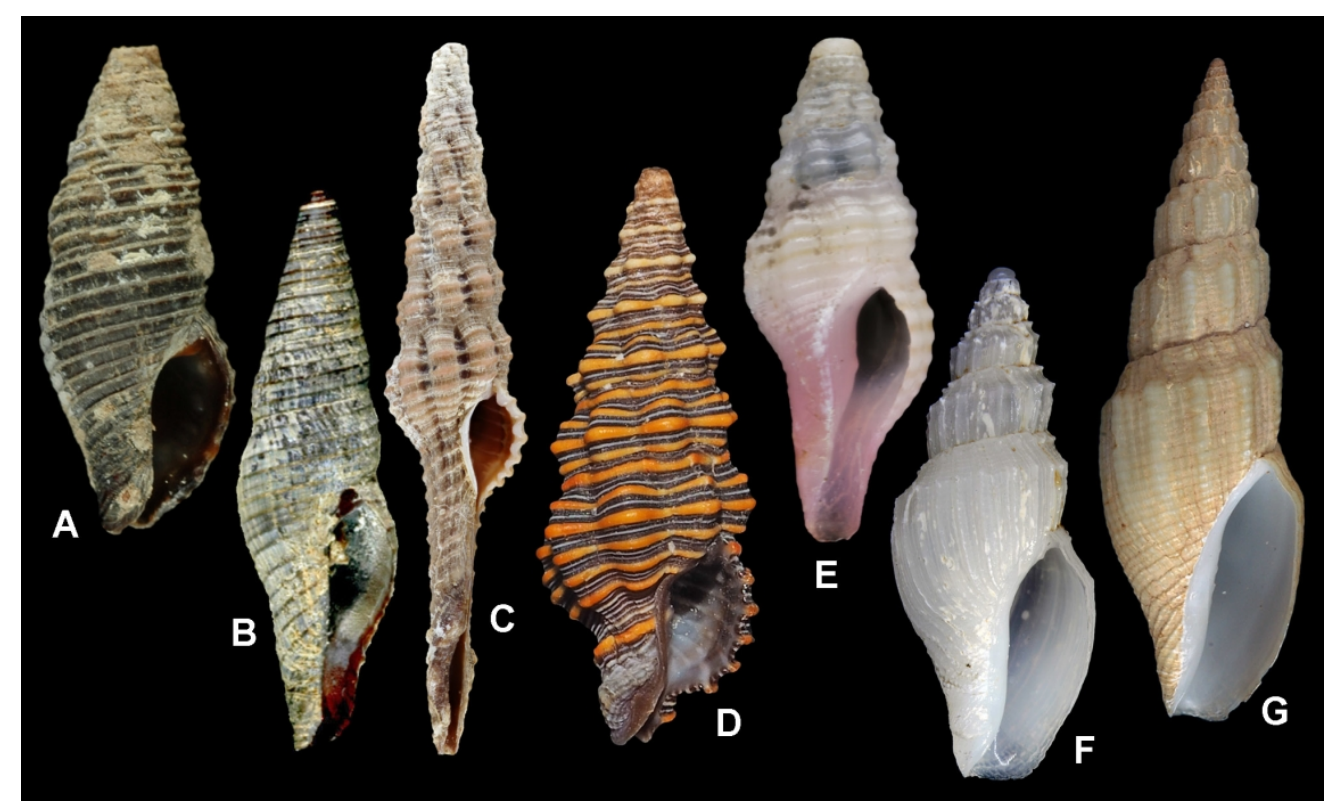

Figure 3. Shells of Dolicholatiridae (A-D) and Belomitridae (E-F). A. Dolicholatirus sp., Western Australia, Esperance, 11 m, MNHN IM-2009-29739, sequenced specimen (radula, see Fig. 4A). B. Dolicholatirus spiceri (Tenison Woods, 1876), MNHN IM-2013-42515. C. Dolicholatirus lancea (Gmelin, 1791), Vietnam, NhaTrang Bay, Mun I., south side, SL 42.5 mm (radula, see Fig. 4C). D. Crassicantharus noumeensis, Marshall Is., Gehh I., Kwajalein Atoll, $16 \mathrm{~m}$, SL $18.2 \mathrm{~mm}$ (photo Scott Johnson). E. Dolicholatirus n.sp., southern New Caledonia, KANACONO st. DW4661, 2245'S, 167013'E, 400-405 m, SL 7.0 mm, MNHN IM-2013-68545, sequenced specimen. F. Belomitra paschalis (Thiele, 1925), Mozambique, MAINBAZA sta. CC3172, 25059'S, 34035'E, 630-638 m, MNHN IM-2009-18856, sequenced specimen, SL 15.0 mm (radula, see Fig. 4D). G. Belomitra bouteti Kantor, Puillandre, Rivasseau \& Bouchet, 2012, holotype, French Polynesia, Society Is., TARASOC st. 3436, 16043'S, 151026'W, 430 m, MNHN IM-2007-24478, SL 32.6 mm (radula, see Fig. 4E). 

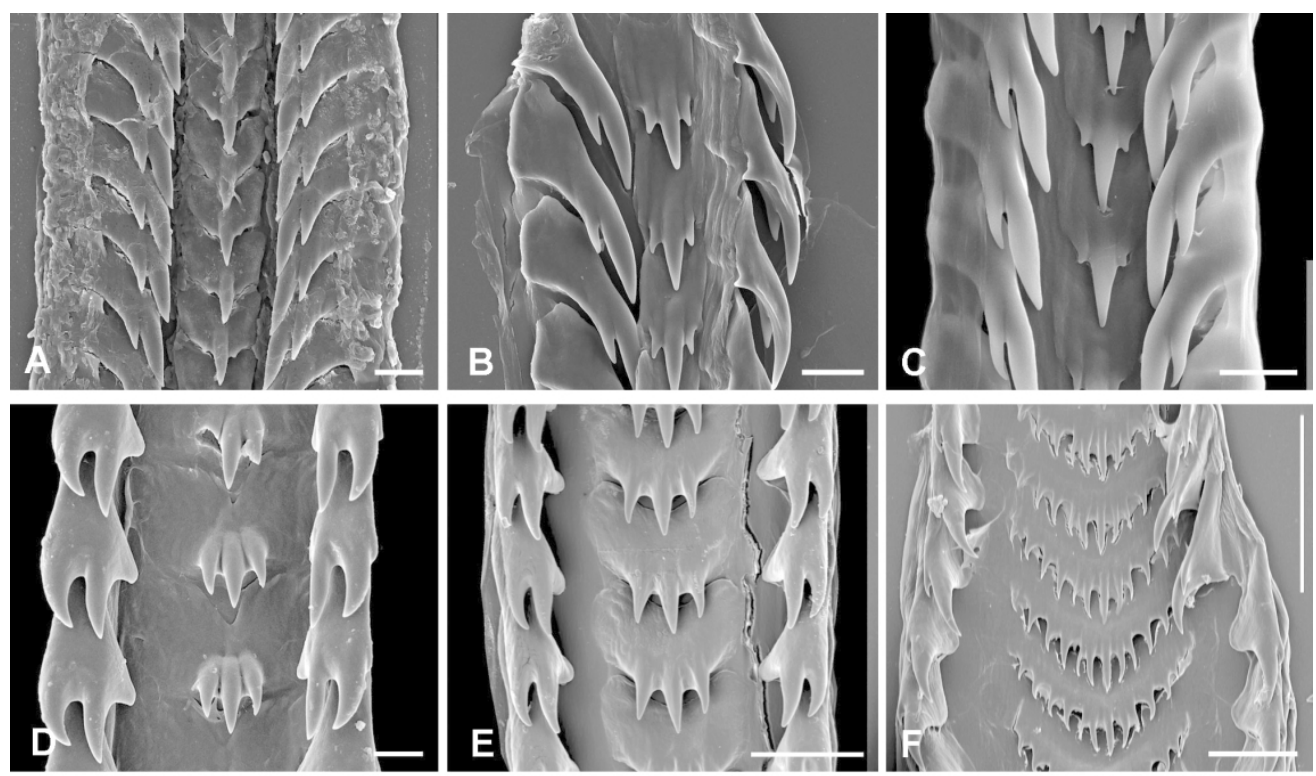

Figure 4. Radulae of Dolicholatiridae and Belomitridae. A. Dolicholatirus sp., Western Australia, Esperance, 11 m, MNHN IM-2009-29739 (shell, see Fig. 3A). B. Dolicholatirus cayhuesonicus (G.B.Sowerby II, 1879), Guadeloupe, KARUBENTHOS 2012 st. GS07, 12 m, MNHN IM-2013-20291. C. Dolicholatirus lancea (Gmelin, 1791), Vietnam, Nha-Trang Bay, Mun I., south side, SL $43.5 \mathrm{~mm}$ (shell, see Fig. 3C). D. Belomitra paschalis (Thiele, 1925), Mosambique, MAINBAZA sta. CC3172, 25059'S, 34035'E, 630-638 m, MNHN IM-2009-18856

(shell, see Fig. 3F). E. Belomitra bouteti Kantor, Puillandre, Rivasseau \& Bouchet, 2012, holotype, French Polynesia, Society Is., TARASOC st. 3436, 16043'S, 151026'W, 430 m, MNHN IM-2007-24478, SL 32.6 mm (shell, see Fig. 3G). F. Belomitra brachytoma (Schepman, 1913), Taiwan 2000 st. CP32, 2201. 7'S, $120^{\circ} 16.4^{\prime} \mathrm{E}, 904 \mathrm{~m}, \mathrm{MNHN}$ unregistered. Scale bars A-D - $10 \mu \mathrm{m}, \mathrm{E}-\mathrm{F}-50 \mu \mathrm{m}$. 

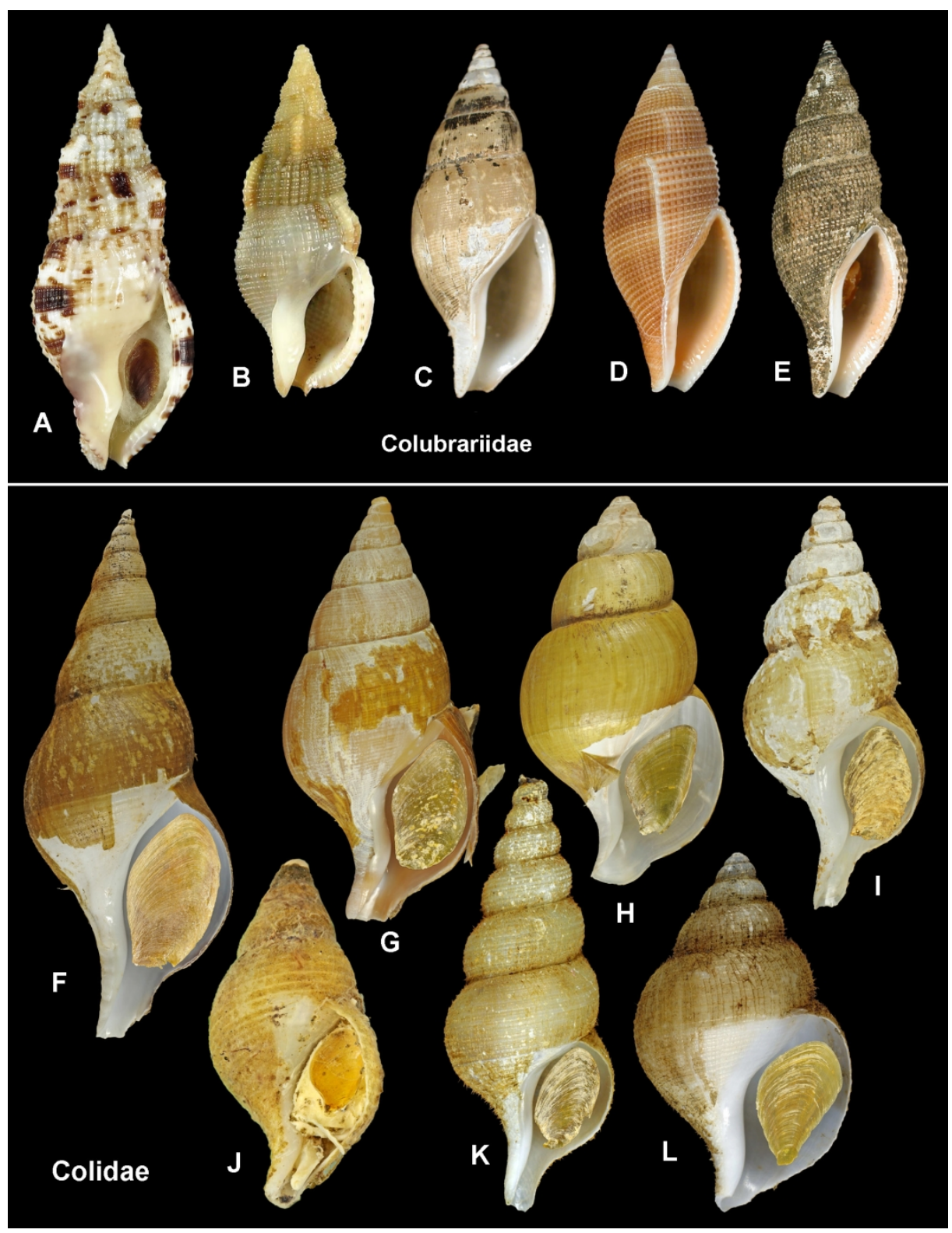

Figure 5. Shells of Colubrariidae (A-E) and Colidae (F-L). A. Colubraria muricata ([Lightfoot, 1786]), Philippines, Mactan I., Punta Engaño, 10-25 m, SL $77.1 \mathrm{~mm}$, (c) Guido \& Philippe Poppe www.conchology.be. B. Cumia reticulata (Blainville, 1829), Mediterranean France, SL 41.3 mm, (C) Guido \& Philippe Poppe - www.conchology.be. C. Kanamarua adonis (Dall, 1919), Philippines, AURORA 2007 st. CP2663, $15^{\circ} 45^{\prime} \mathrm{N}, 121^{\circ} 45^{\prime} \mathrm{E}$, MNHN IM-2007-34640, SL $25.8 \mathrm{~mm}$, sequenced specimen. D. Metula inflata (Houbrick, 1984), Philippines, PANGLAO 2005. st. CP2348, 9³0'N, 12352'E, 196-216 m, MNHN IM-200730079 SL 42.6 mm, sequenced specimen. E. Metula sp., Philippines, AURORA 2007 st. CP2709, 15¹2'N, $121^{\circ} 34^{\prime} E$, $244-296$ m, MNHN IM-2007-34641, SL 37 mm, sequenced specimen. F. Colus islandicus (Møller, 1842), Iceland, $67^{\circ} 16^{\prime} \mathrm{N}, 1^{\circ} 26^{\prime} \mathrm{W}, 296-306 \mathrm{~m}, \mathrm{MNHN}$ IM-2013-78004, SL $100.3 \mathrm{~mm}$, sequenced specimen. G. Colus gracilis (da Costa, 1778), Iceland, 66³' $\mathrm{N}, 2^{\circ} 03^{\circ} \mathrm{W}, 187-222 \mathrm{~m}$, MNHN IM-2013-78018, SL 53.8 $\mathrm{mm}$, sequenced specimen. $\mathrm{H}$. Colus turigulus (Friele, 1877), Iceland, $67^{\circ} 25^{\prime} \mathrm{N}, 1^{\circ} 24.5^{\prime} \mathrm{W}, 906-942 \mathrm{~m}$, MNHN IM-2013-78007, SL $61.2 \mathrm{~mm}$, sequenced specimen. I. Colus holboelli (Møller, 1842), Iceland, $67^{\circ} 02^{\prime} \mathrm{N}, 2^{\circ} 00^{\prime} \mathrm{W}, 236-243 \mathrm{~m}, \mathrm{MNHN}$ IM-2013-78017, SL $35.7 \mathrm{~mm}$, sequenced specimen. J. Colus sabinii

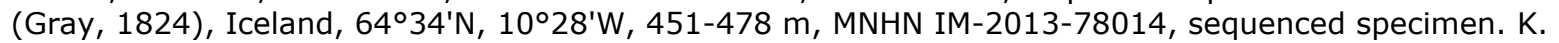


1

2

3

4

5

6

7

8

9

10

11

12

13

14

15

16

17

18

19

20

21

22

23

24

25

26

27

28

29

30

31

32

33

34

35

36

37

38

39

40

41

42

43

44

45

46

47

48

49

50

51

52

53

54

55

56

57

58

59

60

Turrisipho voeringii Bouchet \& Warén, 1985, Iceland, 67²18' N, 2330.5'W, 395-408 m, MNHN IM-201378002, SL $40.4 \mathrm{~mm}$, sequenced specimen. L. Turrisipho moebii (Dunker \& Metzger, 1875), Iceland, $64^{\circ} 21^{\prime} \mathrm{N}, 12^{\circ} 56^{\prime} \mathrm{W}, 149-152 \mathrm{~m}, \mathrm{MNHN}$ IM-2013-78009, SL $35.4 \mathrm{~mm}$, sequenced specimen.

$170 \times 219 \mathrm{~mm}(300 \times 300 \mathrm{DPI})$ 

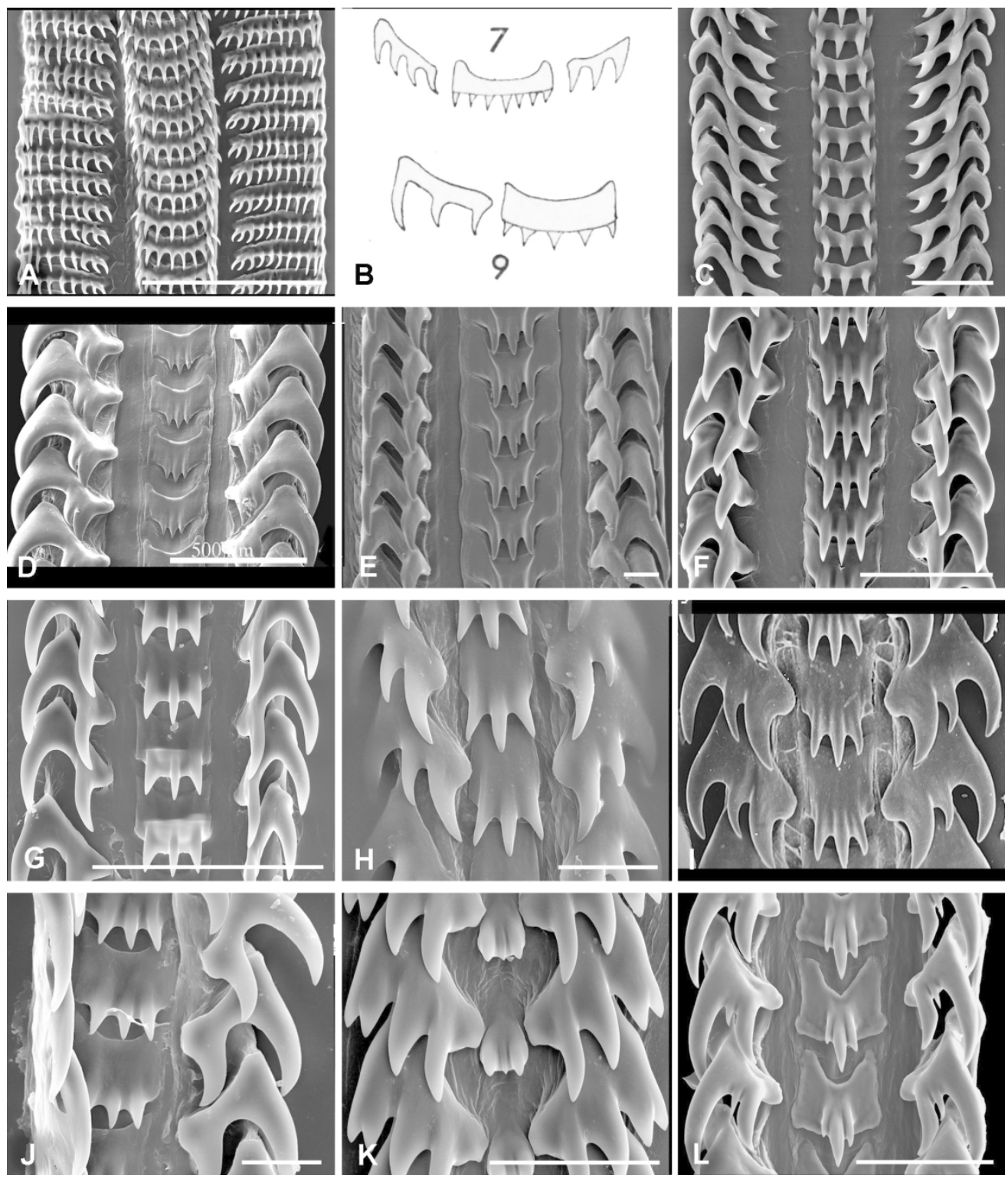

Figure 6. Radulae of Colubrariidae (A-C), Colidae (D) and Eosiphonidae fam. nov. (E-L). A. Colubraria muricata ([Lightfoot, 1786]) (after Oliverio \& Modica, 2010, photo A. Kosyan). B. Cumia mestayerae (Iredale, 1915) (7) and Iredalula striata (Hutton, 1873) (9) (after Ponder, 1968). C. Metula sp., South India, off Tutticorin, from fishermen, IEE uncataloged, SL $35.2 \mathrm{~mm}$. D. Colus islandicus (after Kosyan \& Kantor 2009: fig. 41). E. Enigmaticolus nipponensis (Okutani \& Fujiwara, 2000), Madagascar, MIRIKY st. CP3279, $15^{\circ} 21^{\prime} \mathrm{S}, 4^{\circ} 57^{\prime} \mathrm{E}, 780-1020 \mathrm{~m}, \mathrm{MNHN}$ IM-2009-7079 (shell see on Fig. 7A). F. Manaria kuroharai Azuma, 1960, China Sea, ZHONGSHA 2015 st. CP4152, 165'N, 11355'E, 410-412 m, MNHN IM-2013-59292, SL $47.7 \mathrm{~mm}$ (shell see on Fig. 7I). G. Gaillea cf canetae (Clench \& Aguayo, 1944), Guadeloupe, KARUBENTHOS 2 st. CP4513, $16^{\circ} 13^{\prime} \mathrm{N}, 61^{\circ} 54^{\prime} \mathrm{W}, 406-644 \mathrm{~m}, \mathrm{MNHN}$ IM-2013-60080 (sequenced specimen). H. Eclectofusus sp., Papua-New Guinea, PAPUA NIUGINI st. CP3949, 5¹2'S, 14551'E, 380-407 m, MNHN IM-2013-4813

(sequenced specimen). I. Eclectofusus dedonderi (Fraussen \& Hadorn, 2001), paratype, Philippines,

Balicasag I., tangle nets at 120-150 m, coll. KF-3206 (shell, see Fig. 7G). J. Eosiphonidae Gen. sp.,

Guadeloupe, KARUBENTHOS 2 st. CP4543, 16²4'N, 6134'W, 385-399 m, MNHN IM-2013-60365 (shell, see Fig. 7L). K. Warenius sp., China Sea, ZHONGSHA 2015 st. CP4134, 1950'N, 116²7'E, 1128-1278 m, MNHN IM-2013-61665 (sequenced specimen). L. Americominella longisetosa (Castellanos \& Fernandez, 
1972) (after Penchaszadeh et al., 2019, photo G. Pastorino Scale bars: A, K - $50 \mu \mathrm{m}, \mathrm{C}, \mathrm{H}, \mathrm{J}-20 \mu \mathrm{m}, \mathrm{D}-500 \mu \mathrm{m}, \mathrm{E}, \mathrm{F}, \mathrm{G}, \mathrm{L}-100 \mu \mathrm{m}$.

$170 \times 199 \mathrm{~mm}(300 \times 300 \mathrm{DPI})$ 


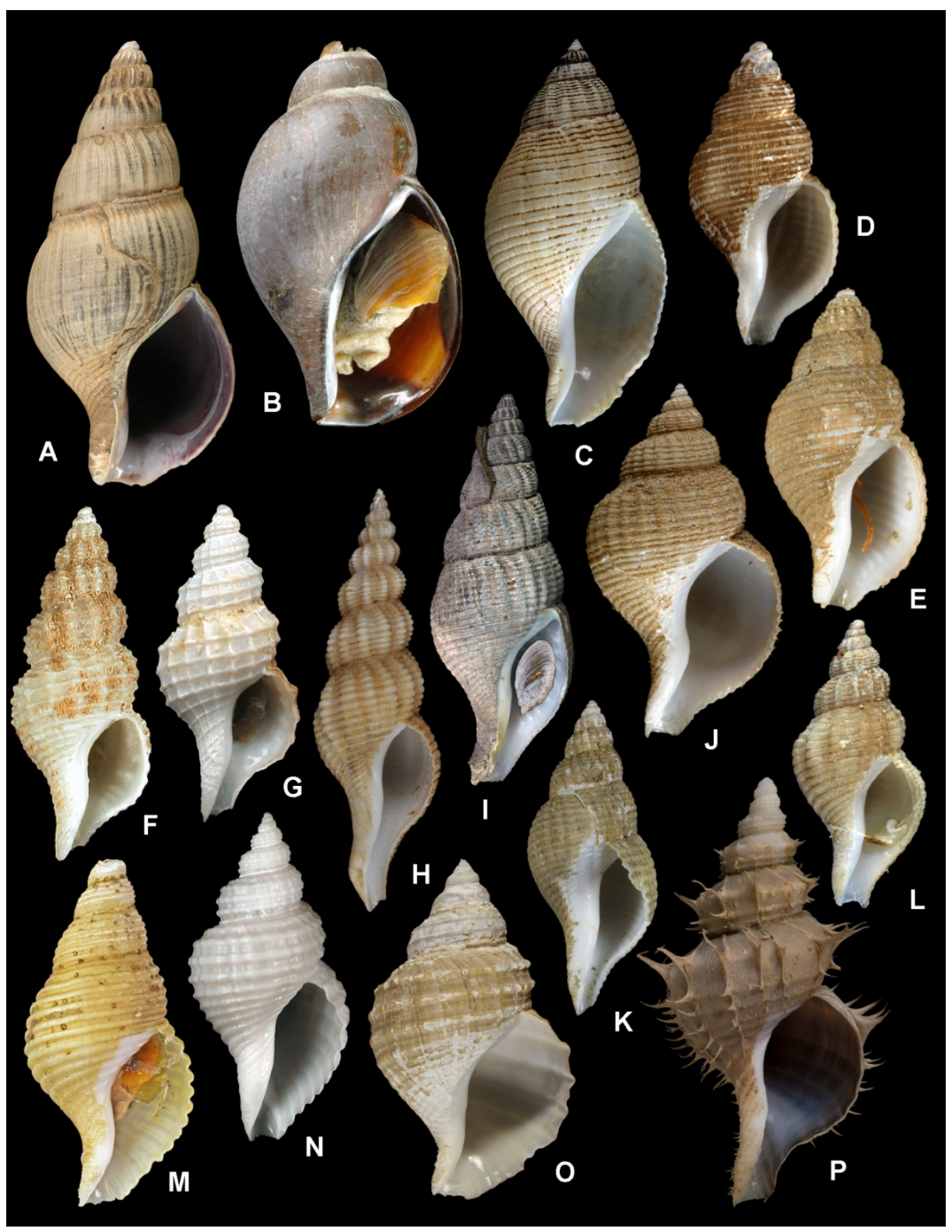

Figure 7. Shells of Eosiphonidae fam. nov. A. Enigmaticolus nipponensis (Okutani \& Fujiwara, 2000), Madagascar, MIRIKY st. CP3279, 1521'S, 455'ㅌ, 780-1020 m, MNHN IM-2009-7079, SL 99.4 mm, sequenced specimen (radula, see Fig. 6A). B. Thermosipho auzendei (Warén \& Bouchet, 2001), holotype,

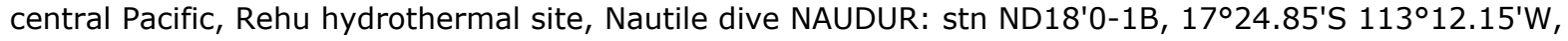
2578 m, MNHN IM-2000-7049, SL 62 mm. C. Eosipho smithi (Schepman, 1911), Vanuatu, SANTO 2006 st. AT103, 150'38'S; 16651'E, 373-721 m, MNHN IM-2007-32983, SL 56.1 mm. D. Calagrassor bacciballus Fraussen \& Stahlschmidt, 2016, Philippines, Bohol Sea, PANGLAO 2005 st. CP2356, 9² $21^{\prime} \mathrm{N} ; 124^{\circ} 9^{\prime} \mathrm{E}, 1^{1764}$ m, MNHN IM-2007-32940, SL 13.2 mm. E. Calagrassor aldermenensis (Powell, 1971), Philippines, AURORA

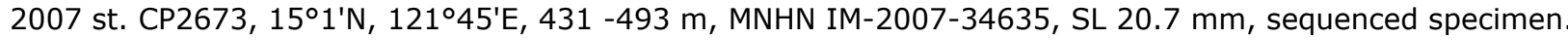

F. "Manaria" fluentisona Fraussen \& Stahlschmidt, 2016, holotype, Solomon Is., SALOMONBOA 3 st.

DW2790, 8¹9'S, 160³7'E, 314-586 m, MNHN IM-2007-35942, SL 15.4 mm. G. Eclectofusus dedonderi

(Fraussen \& Hadorn, 2001) paratype 12, Philippines, Balicasag I., tangle nets at 120-150 m, coll. KF-3206, SL $11.6 \mathrm{~mm}$. H. Manaria formosa Bouchet \& Warén, 1986, Madagascar, MIRIKY st. CP3183, 12³8'S, 48¹4'E, 420-436 m, MNHN IM-2007-36855, SL 55 mm. I. Manaria kuroharai Azuma, 1960, China Sea, 
ZHONGSHA 2015 st. CP4152, 165'N, 113055'E, 410-412 m, MNHN IM-2013-59292, SL 47.7 mm, sequenced specimen (radula see Fig. 6F). J. Gaillea coriolis (Bouchet \& Warén, 1986), Philippines, AURORA 2007 st. CP2699, 14ํ5' $\mathrm{N}, 123^{\circ} 35^{\prime} \mathrm{E}, 541-583$ m, MNHN IM-2007-34637, SL 31 mm. K. Calagrassor sp. 2,

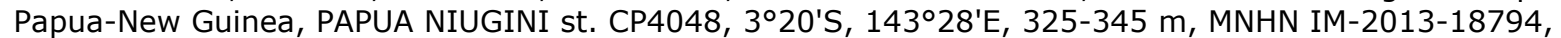
sequenced specimen. L. Eosiphonidae Gen. sp., Guadeloupe, KARUBENTHOS 2 st. CP4543, $16^{\circ} 40^{\prime} \mathrm{N}$, 6134'W, 385-399 m, MNHN IM-2013-60365, SL 11.3 mm, sequenced specimen (radula, see Fig. 6J). M.

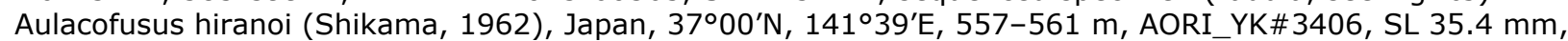
sequenced specimen. N. Preangeria dentata (Schepman, 1911), Philippines, PANGLAO 2005 st. CP2349, $9^{\circ} 32^{\prime} \mathrm{N}, 123^{\circ} 56^{\prime} \mathrm{E}, 219-240 \mathrm{~m}$, IM-2007-32656, SL $22.8 \mathrm{~mm}$. O. Warenius crosnieri (Bouchet \& Warén,

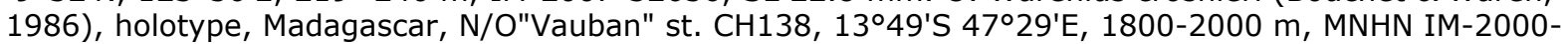
6369, SL 33.7 mm. P. Americominella longisetosa (Castellanos \& Fernandez, 1972) (after Penchaszadeh et al., 2019), SL 98 mm, photo G. Pastorino.

$170 \times 219 \mathrm{~mm}(300 \times 300 \mathrm{DPI})$ 


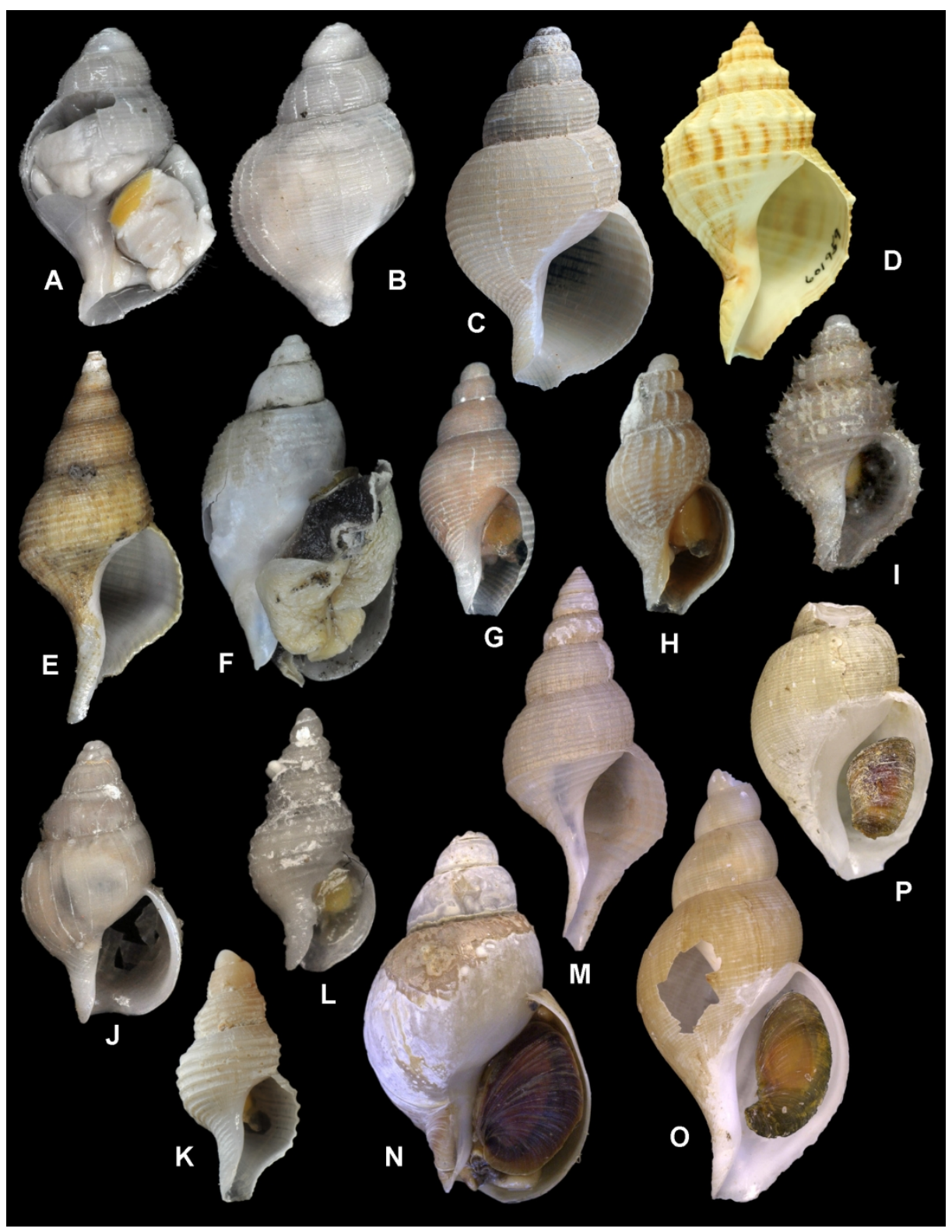

Figure 8. Shells of Prosiphonidae. A-B. Antarctodomus thielei (Powell, 1958), Ross Sea, Antarctica, 65²5'S, 16053'E. 114 m, MNA00183, SL 18 mm, sequenced specimen. C. Antarctodomus cf. powelli Dell, 1995, Tasmania, NC0009, SL $42.1 \mathrm{~mm}$, sequenced specimen. D. Austrofusus glans (Röding, 1798), New Zealand, South Island, Nelson, Collingwood, Pakawai, USNM 601959, SL 40 mm. E. Cavineptunea cf. monstrosa Powell, 1951, Bransfield Strait, Antarctica, MNA11734, SL 39.8 mm, sequenced specimen. F. Chlanidota signeyana Powell, 1951, Bransfield Strait, Antarctica, MNA6718. SL 33.5 mm, sequenced specimen. G.

Falsimohnia innocens (E.A.Smith, 1907), Bransfield Strait, Antarctica, MNA11387, SL 5.6 mm, sequenced specimen. H. Falsimohnia minor (Strebel, 1908), Bransfield Strait, Antarctica, MNA11409, SL 6.5 mm, sequenced specimen. I. Proneptunea sp., Bransfield Strait, Antarctica, MNA11364, SL 6.1 mm, sequenced specimen. J. Probuccinum tenerum (E.A.Smith, 1907), Bransfield Strait, Antarctica, MNA11740, SL 17.4 mm. K. Prosipho spiralis Thiele, 1912, Bransfield Strait, Antarctica, MNA11398, SL 7.1 mm, sequenced specimen. L. Prosipho mundus E.A.Smith, 1915, Ross Sea, Antarctica, 454 m, MNA6308, SL 7.6 mm, sequenced specimen. M. Drepanodontus tatyanae Harasewych \& Kantor, 2004, holotype, Scotia Sea, Antarctica, 59²'S, 51 ${ }^{\circ} 53^{\prime} \mathrm{W}, 3010-3510 \mathrm{~m}$, USNM 1010544, SL $43.1 \mathrm{~mm}$. N. Neobuccinum eatoni 
(E.A.Smith, 1875), Antarctica, South Shetland Is., King George I., 62 $10^{\prime}$ S, 57⒋'W, 610-625 m, USNM 897630, SL 39 mm. O. Germonea rachelae Harasewych \& Kantor, 2004, holotype, Antarctica, off South Georgia I., 58 02'S, 3757'W, 3197-3239 m, USNM 896594, SL 61.8 mm. P. Muffinbuccinum catherinae Harasewych \& Kantor, 2004, holotype, South Atlantic Ocean [Argentine Abyssal Plain], 47 17'S, 47²46'W, 5685-5798 m, USNM 1010623, SL $26.4 \mathrm{~mm}$.

$170 \times 219 \mathrm{~mm}(300 \times 300 \mathrm{DPI})$ 

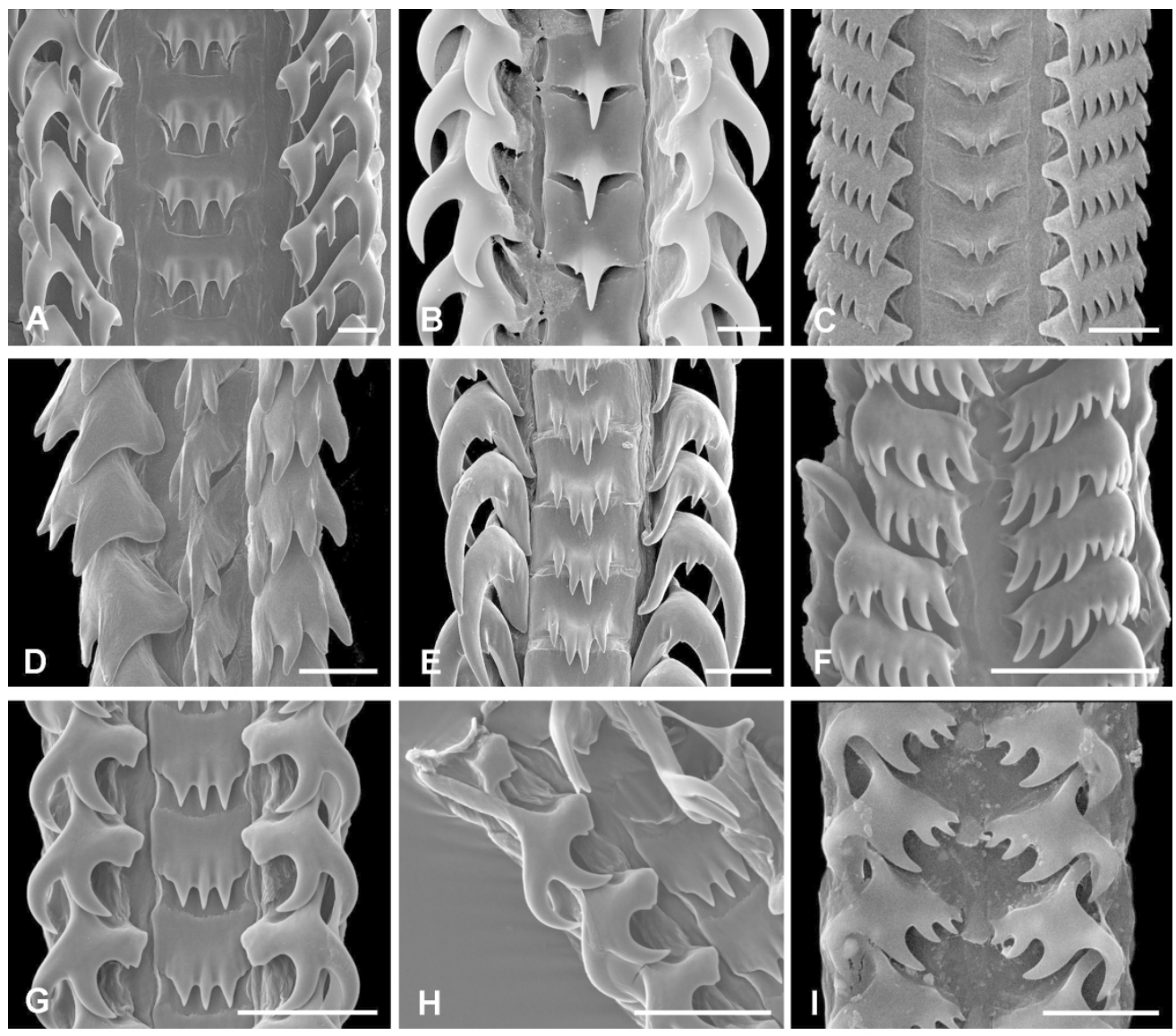

Figure 9. Radulae of Prosiphonidae. A. Neobuccinum eatoni (E.A.Smith, 1875), Antarctica, Adélie Land, $66^{\circ} 35^{\prime} \mathrm{S}, 143^{\circ} 5^{\prime} \mathrm{E}, 862-875 \mathrm{~m}, \mathrm{MNHN}$ IM-2009-8220. B. Falsimohnia minor (Strebel, 1908), syntype, South Georgia I., outer Cumberland Bay, 54ำ1'S, 36¹8'W, 252-310 m, SMNH Type-1057. C. Muffinbuccinum catherinae Harasewych \& Kantor, 2004, paratype 1, South Atlantic Ocean [Argentine Abyssal Plain], 47¹7' S, 47046'W, 5685-5798 m, USNM 1010624. D. Germonea rachelae Harasewych \& Kantor, 2004, holotype, off South Georgia I., 58 02' S, 37057'W, 3197-3239 m, USNM 896594. E. Drepanodontus tatyanae Harasewych \& Kantor, 2004, paratype I, E of South Sandwich Is., 5700'S, 26¹0'W, 2740- 2757 m, USNM 881529. F. Falsimacme kobelti (Strebel, 1905), Argentina, photo G. Pastorino. G-H. Argeneuthria cerealis

(Rochebrune \& Mabille, 1885), Tierra del Fuego, photo G. Pastorino. I. Antistreptus magellanicus (Dall,

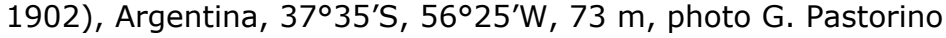
Scale bars: A, C, D, E - $100 \mu \mathrm{m}, \mathrm{B}, \mathrm{I}-10 \mu \mathrm{m}, \mathrm{F}, \mathrm{G}, \mathrm{H}-30 \mu \mathrm{m}$. 


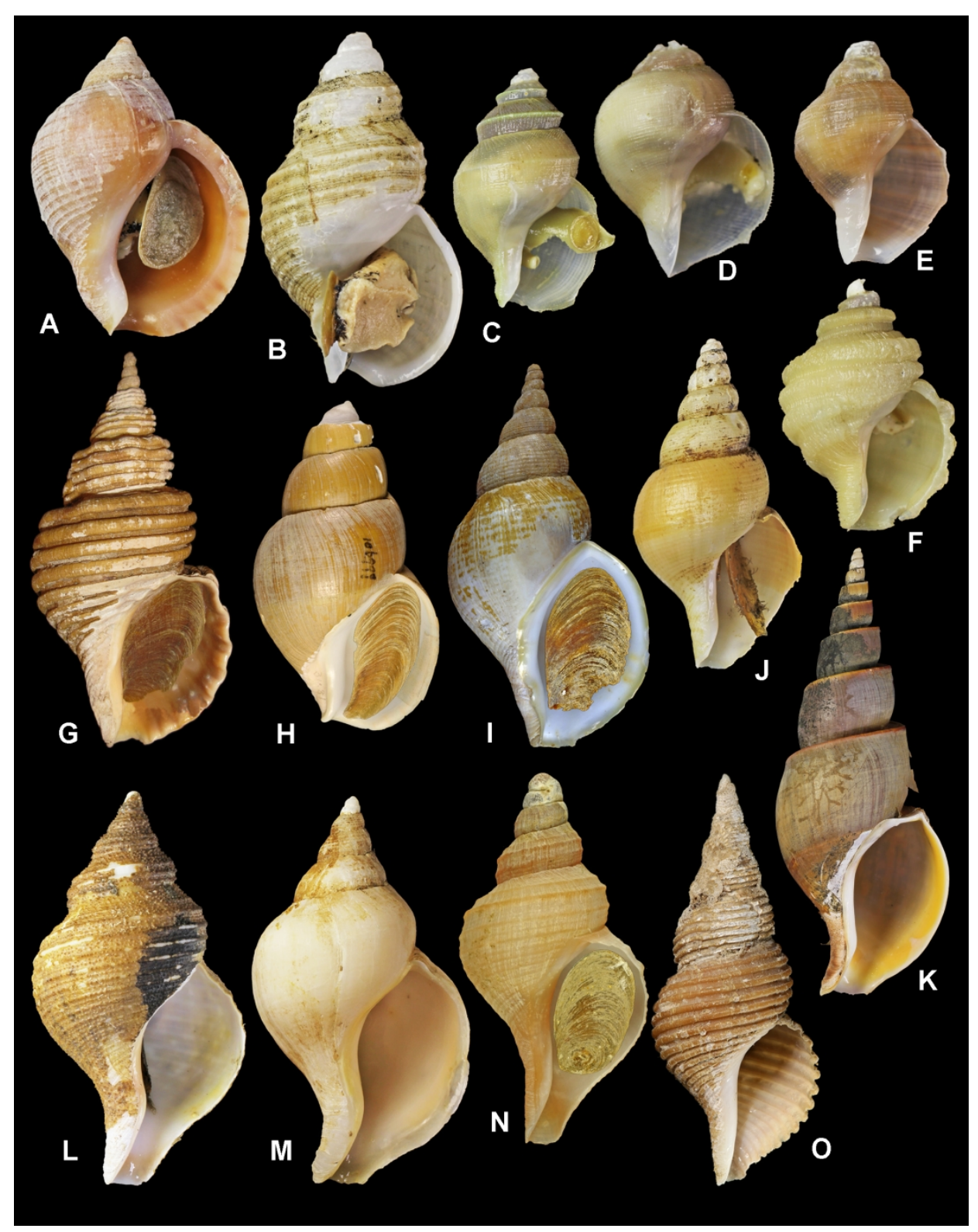

Figure 10. Shells of Buccinidae. A. Buccinum chishimanum Pilsbry, 1904, Japan, Hokkaido, 4258'N, 1445' $3^{\prime}$, intertidal, AORI_YK\#3988, SL 29.0 mm, sequenced specimen. B. Buccinum nipponense Dall,

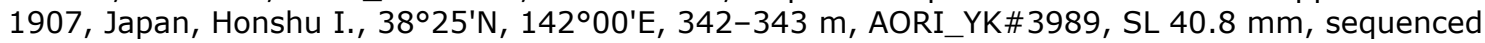

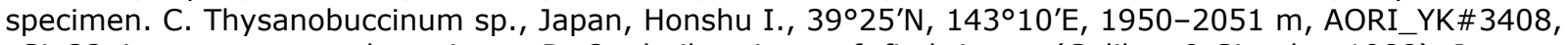
SL $22.4 \mathrm{~mm}$, sequenced specimen. D. Ovulatibuccinum cf. fimbriatum (Golikov \& Sirenko, 1988), Japan, Honshu I., $38^{\circ} 25^{\prime} \mathrm{N}, 142^{\circ} 00^{\prime} \mathrm{E}, 342-343 \mathrm{~m}$, SL $9.0 \mathrm{~mm}$, sequenced specimen. E. Bathybuccinum bicordatum Golikov \& Sirenko, 1988, Japan, Honshu I., 38²5'N, 14200'E, 342-343 m, AORI_YK\#3992, SL 8.4 mm, sequenced specimen. F. Thysanobuccinum n. sp., Japan, $38^{\circ} 16^{\prime} \mathrm{N}, 143^{\circ} 32^{\prime} \mathrm{E}, 3302-3311 \mathrm{~m}$,

AORI_YK\#3402, SL 20.3 mm, sequenced specimen. G. Beringius crebricostatus (Dall, 1877), Aleutian Is., $54^{\circ} 05^{\prime} \mathrm{N}, 166^{\circ} 23^{\prime} \mathrm{W}, 88 \mathrm{~m}$, RNC_4149, SL $127.7 \mathrm{~mm}$, sequenced specimen. H. Beringius aleuticus Dall, 1895, holotype, Aleutian Is., SE of Seguam I., 52 ${ }^{\circ} 15^{\prime} \mathrm{N}, 171^{\circ} 40^{\prime} \mathrm{W}, 454 \mathrm{~m}$, USNM 106999, SL $65 \mathrm{~mm}$. I.

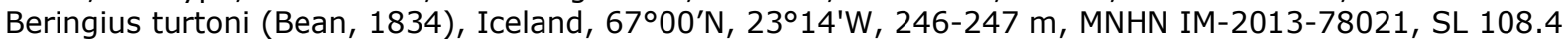
$\mathrm{mm}$, sequenced specimen. J. Metajapelion adelphicus (Dall, 1907), Japan, Kyushu Is., 32006'N, 129029'E, 606-610 m, AORI_YK\#3975, SL 54.1 mm, sequenced specimen (radula, see Fig. 13C). K. Metajapelion 
pericochlion (Schrenck, 1863), Japan, AORI_YK\#4142, SL $117.7 \mathrm{~mm}$, specimen sequenced for cox-1. L. Neptunea kurosio Oyama, 1959, Japan, Kyushu I., 32010'N, 129030'E, 470-487 m, AORI_YK\#3985, SL 86.4 mm, sequenced specimen. M. Neptunea fukueae Kira, 1959, Japan, Kyushu I., 32010'N, 129030'E, 470-487 m, AORI_YK\#3658, SL $61.7 \mathrm{~mm}$, sequenced specimen. N. Neptunea despecta (Linnaeus, 1758), Iceland, $67^{\circ} 49^{\prime} \mathrm{N}, 2^{\circ} 44,5^{\prime} \mathrm{W}, 755-770 \mathrm{~m}$, MNHN IM-2013-78010, SL $41.2 \mathrm{~mm}$, sequenced specimen. O. Aulacofusus periscelidus (Dall, 1891), Kurile Is., Urup Is., $45^{\circ} 55.2^{\prime} \mathrm{N}, 150^{\circ} 15.8^{\prime} \mathrm{E}, 169-150 \mathrm{~m}$, IEE BUC270, SL 58.5 mm, specimen sequenced for cox-1. 

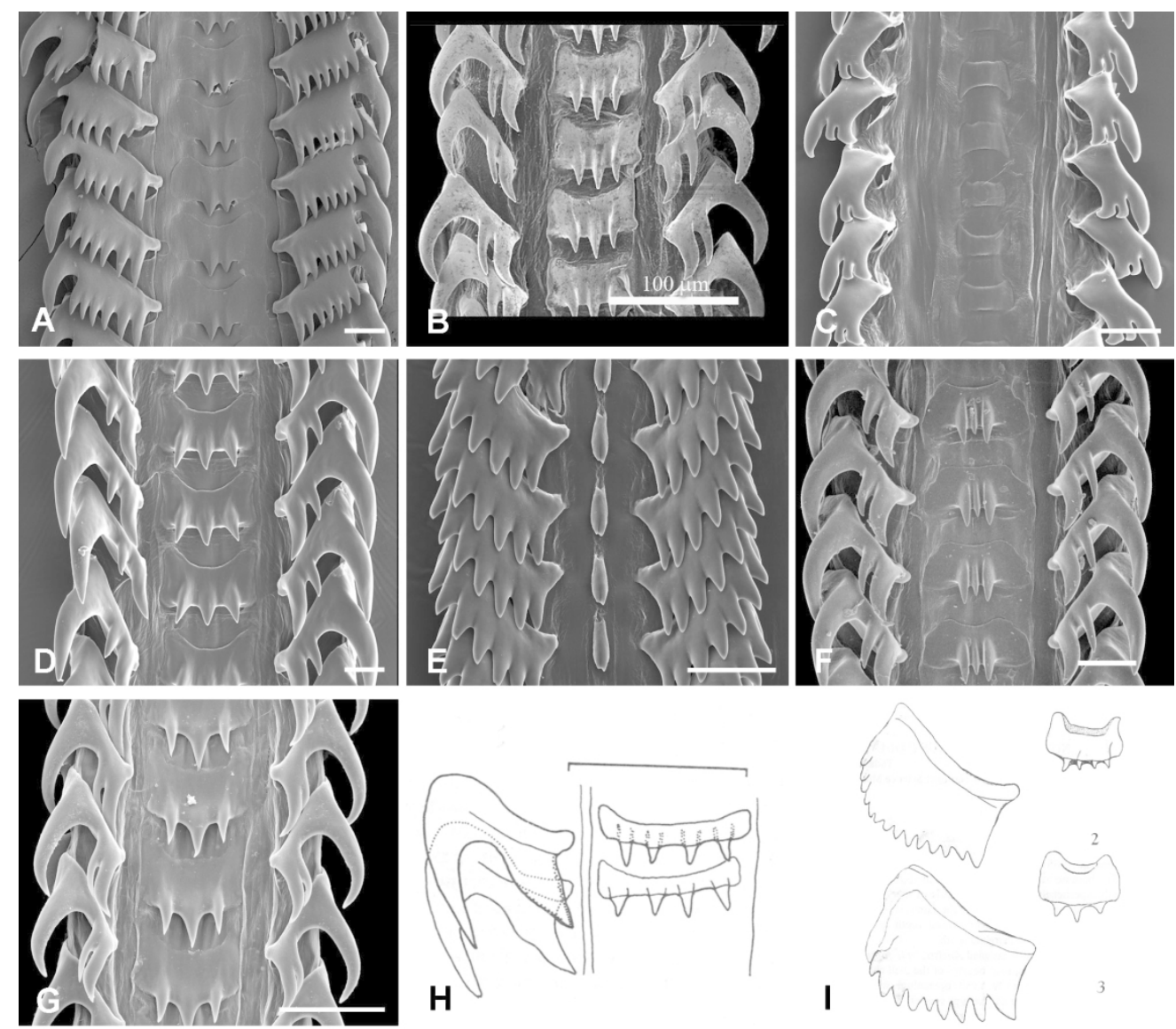

Figure 11. Radulae of Buccinidae. A. Neptunea costaria Fraussen \& Terryn, 2007, holotype of Costaria borealis Golikov, 1977, Iturup I. [South Kurile Is.], 414 m, ZIN 30873/1. B. Aulacofusus periscelidus (Dall, 1891), Kurile Is., Urup I., Kitovy Cape, 50 m, ZIN 55945 (after Kosyan \& Kantor, 2013: fig. 5 E). C.

Metajapelion adelphicus (Dall, 1907), Japan, Kyushu Is., 32006'N, 129029'E, 606-610 m, AORI_YK\#3975, SL $54.1 \mathrm{~mm}$ (shell, see Fig. 12I). D. Japelion hirasei (Pilsbry, 1901), Japan, Honshu I., 39²2' N, $142^{\circ} 15^{\prime} \mathrm{E}^{\circ}$ 479-484 m, AORI_YK\#3449, SL 95.8 mm (shell, see Fig. 14F). E. Thalassoplanes moerchi (Dall, 1908),

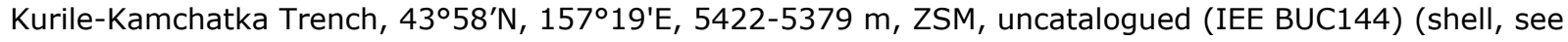
Fig. 14I). F. Clinopegma magnum unicum (Pilsbry, 1905), form damon, south-eastern Sakhalin, $46^{\circ} 28^{\prime} \mathrm{N}$, $142^{\circ} 52^{\prime} \mathrm{E}$, in $44 \mathrm{~m}$, Zoological Museum of Moscow State University, uncatalogued, SL $97.8 \mathrm{~mm}$. G.

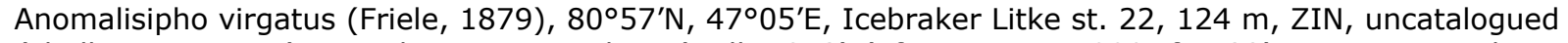
(shell see Fig, 14K). H. Volutopsius regularis (Dall, 1873) (after Kantor, 1990: fig. 32). I. Parancistrolepis fujitai (Kuroda, 1931) (2) and P. kinoshitai (Kuroda, 1931) (3) (after Habe, 1972). Scale bars: A, B-E, G - $100 \mu \mathrm{m} ; \mathrm{F}-200 \mu \mathrm{m}$. 


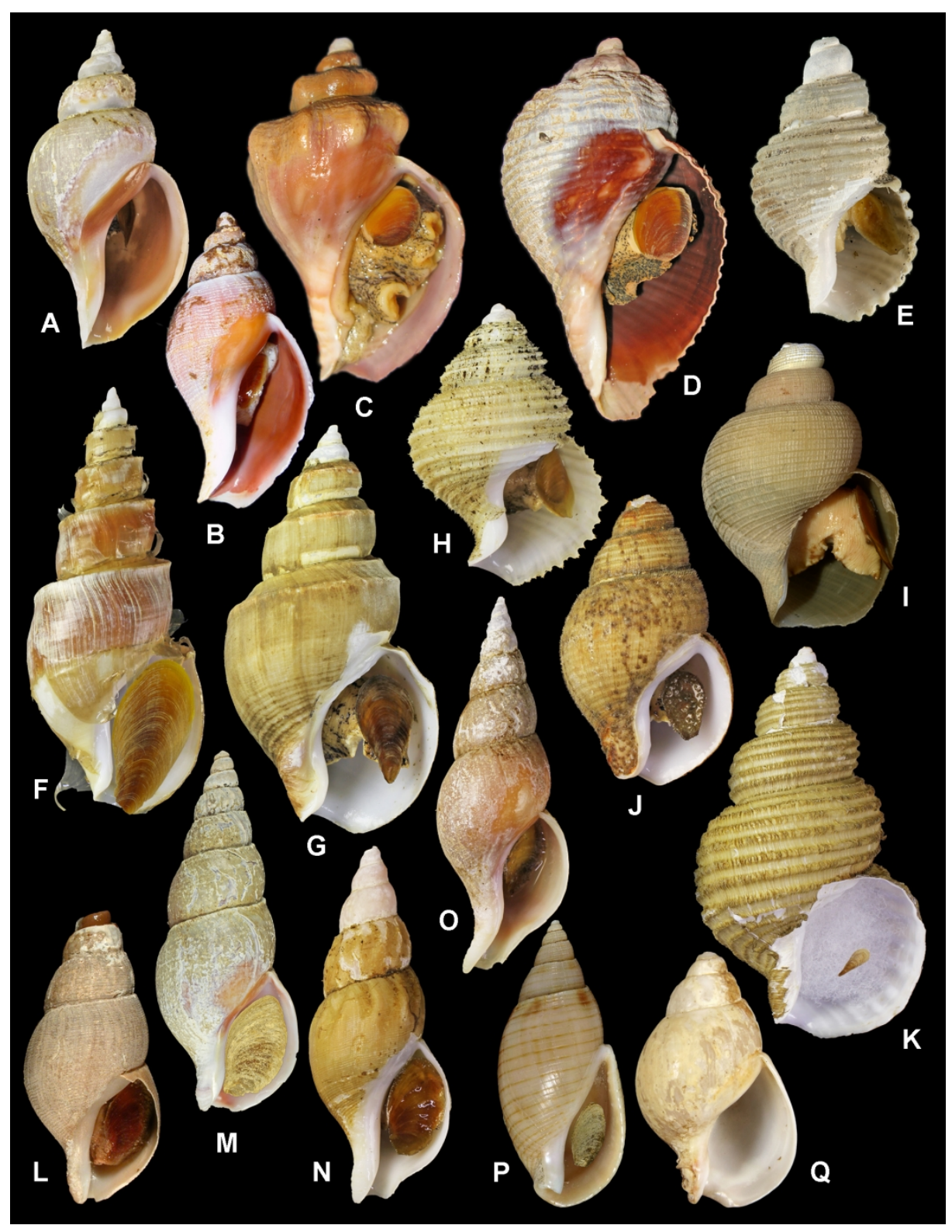

Figure 12. Shells of Buccinidae. A. Habevolutopsius hirasei (Pilsbry, 1907), Japan, Honshu I., 405'슨 141046'E, 459-498 m, AORI_YK\#3657, SL 62.4 mm, sequenced specimen. B. Lussivolutopsius filosus (Dall, 1919), Bering Sea, $60^{\circ} 01^{\prime} \mathrm{N}, 168^{\circ} 39^{\prime} \mathrm{W}, 37 \mathrm{~m}, \mathrm{RNC} 4493, \mathrm{SL} 52.8 \mathrm{~mm}$, sequenced specimen. C. Volutopsius fragilis (Dall, 1891), Chukchi Sea, $71^{\circ} 31^{\prime} \mathrm{N}, 157^{\circ} 23^{\prime} \mathrm{W}, 88 \mathrm{~m}, \mathrm{RNC} 4552, \mathrm{SL} 74.2 \mathrm{~mm}$, sequenced specimen. D. Pyrulofusus dexius Dall, 1907, Aleutian Is, 52 ${ }^{\circ} 56^{\prime} \mathrm{N}, 170^{\circ} 59^{\prime} \mathrm{E}, 185$ m, RNC_4870, SL 148 mm, sequenced specimen. E. Ancistrolepis grammatus (Dall, 1907), Okhotsk Sea, Kurile Is., Onekotan I., 49 $31^{\prime} \mathrm{N}, 154^{\circ} 25^{\prime} \mathrm{E}, 571-580 \mathrm{~m}$, IEE Bu-OS-1188, SL $21.4 \mathrm{~mm}$, specimen sequenced for cox-1. F. Japelion hirasei (Pilsbry, 1901), Japan, Honshu I., 39²2'N, 142¹5'E, 479-484 m, AORI_YK\#3449, SL $95.8 \mathrm{~mm}$ (radula, see Fig. 13D). G. Clinopegma magnum unicum (Pilsbry, 1905), Japan, Honshu I., $38^{\circ} 25^{\prime} \mathrm{N}, 142^{\circ} 00^{\prime} \mathrm{E}, 342-343 \mathrm{~m}$, AORI_YK\#3403, SL $75.7 \mathrm{~mm}$, sequenced specimen. H. Bathyancistrolepis

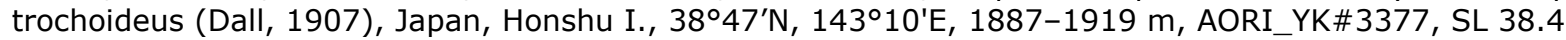
$\mathrm{mm}$, sequenced specimen. I. Thalassoplanes moerchi (Dall, 1908), Kurile-Kamchatka Trench, $43^{\circ} 58^{\prime} \mathrm{N}$, 157019'E, 5422-5379 m, ZSM, uncataloged (IEE BUC144), SL 31.4 mm, sequenced specimen (radula, see Fig. 13E). J. Pseudoliomesus canaliculatus (Dall, 1874), Japan, AORI_YK\#4141, SL 32.2 mm, specimen 
sequenced for cox-1. K. Parancistrolepis fujitai (Kuroda, 1931), Japan, AORI_YK\#3401, SL 81.4 mm, specimen sequenced for cox-1. L. Anomalisipho virgatus (Friele, 1879), Spitzbergen, $80^{\circ} 57^{\prime} \mathrm{N}, 47^{\circ} 05^{\prime} \mathrm{E}$, Icebraker Litke st. 22, $124 \mathrm{~m}$, ZIN, uncatalogued, SL $40.3 \mathrm{~mm}$ (radula, see Fig. 13G). M. Anomalisipho

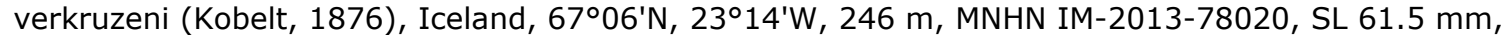
sequenced specimen. N. Plicifusus rhyssus (Dall, 1907), Japan, AORI_YK\#4211, SL 46.7 mm, specimen sequenced for cox-1. O. "Colus" kujianus Tiba, 1973, Japan, AORI_YK\#4210, SL 57.7 mm, specimen sequenced for cox-1. P. Liomesus ovum (Turton, 1825), Scotland, SL $29.1 \mathrm{~mm}$ ( ) Guido \& Philippe Poppe www.conchology.be. Q. Truncaria filosa (A. Adams \& Reeve, 1850) (holotype of Cominella brunneocincta Dall, 1896), Albatross st. 3390, Gulf of Panama, 102 m, USNM 123009, SL 31.5 mm (photo USNM).

$170 \times 219 \mathrm{~mm}(300 \times 300 \mathrm{DPI})$ 
Figure 13. Shells of Siphonaliidae. A. Pararetifusus tenuis (Okutani, 1966), off Kesennuma, Miyagi, Honshu I., Japan, $38^{\circ} 47^{\prime} \mathrm{N}, 143^{\circ} 10^{\prime} \mathrm{E}, 1887-1919 \mathrm{~m}, \mathrm{SL} 11.6 \mathrm{~mm}$, sequenced spm (BUC 181). B. Bayerius holoserica (Lus, 1971), KURAMBIO I st. AGT 6-9, north-western Pacific, 42²9’N, $154^{\circ} 00^{\prime} \mathrm{E}, 5293-5307 \mathrm{~m}, \mathrm{SL} 48.9$ mm, sequenced specimen (radula, see Fig. 11A). C. Bayerius knudseni (Bouchet \& Warén, 1986).

KURAMBIO I st. AGT 12-5, north-western Pacific, 394 $4^{\prime} \mathrm{N}, 147^{\circ} 10^{\prime} \mathrm{E}, 5229-5217 \mathrm{~m}, \mathrm{SL} 23.9 \mathrm{~mm}$, sequenced specimen (radula, see Fig.11B). D. Phaenomenella insulapratasensis (Okutani \& Lan, 1994), South China Sea, DONGSHA 2014 st. CP4129, 20²9'N, 1168'E, 590-633 mm, MNHN IM-2013-50203, SL $38.7 \mathrm{~mm}$, sequenced specimen. E. Phaenomenella nicoi Kantor, Kosyan, Sorokin \& Fedosov, 2020, holotype, South China Sea, SW off Dong Sha, ZHONGSHA 2015; st. CP4132, 2007'N, 116²2'E, 958-988 m, MNHN IM-2013-61585, SL $41.1 \mathrm{~mm}$, sequenced specimen (radula, see Fig. 11D). F. Siphonalia spadicea (Reeve, 1847), South China Sea, TAIWAN 2004 st. CP244, 245' N, 121 56'E, 122-123 m, MNHN IM-2007-32856, SL $51.8 \mathrm{~mm}$, sequenced specimen. G. Mohnia dalli (Friele, 1881), Barents Sea, $72^{\circ} 23^{\prime} \mathrm{N}, 1^{\circ} 58^{\prime} \mathrm{E}, 702 \mathrm{~m}, \mathrm{SL}$ $24.6 \mathrm{~mm}$, sequenced specimen.

$170 \times 151 \mathrm{~mm}(300 \times 300$ DPI $)$ 

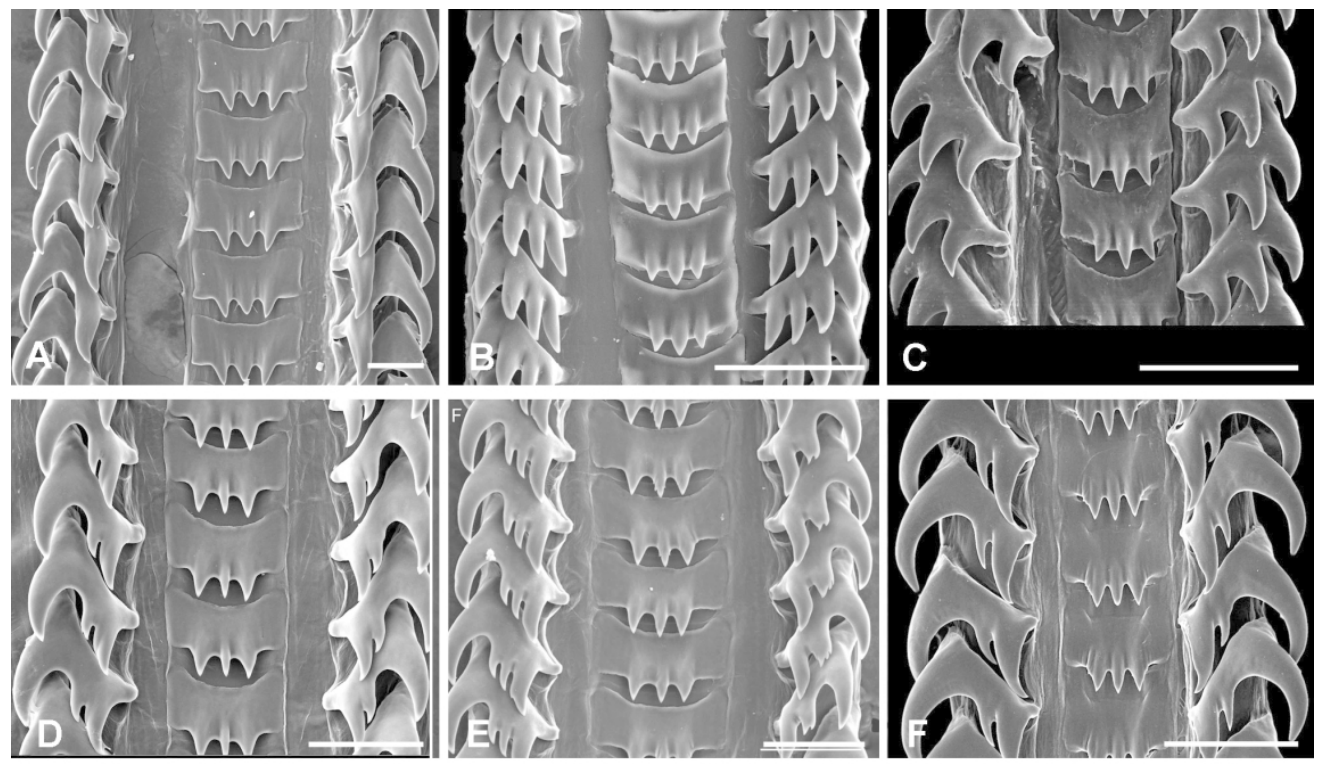

Figure 14. Radulae of Siphonaliidae. A. Bayerius holoserica (Lus, 1971), KURAMBIO I st. AGT 6-9, northwestern Pacific, $42^{\circ} 29^{\prime} \mathrm{N}, 1^{\circ} 4^{\circ} 00^{\prime} \mathrm{E}, 5293-5307 \mathrm{~m}$ (shell, see Fig. 10B). B. Bayerius knudseni (Bouchet \& Warén, 1986). KURAMBIO I st. AGT 12-5, north-western Pacific, 3944' N, $147^{\circ} 10^{\prime} \mathrm{E}, 5229-5217 \mathrm{~m}$ (shell, see on Fig. 10C). C. Pararetifusus tenuis (Okutani, 1966), Kurile Is., off Iturup I., $44^{\circ} 20^{\prime} \mathrm{N}, 1^{\circ} 48^{\circ} 24^{\prime} \mathrm{E}$, 414 m, ZIN 58795/6 (after Kosyan, 2006, fig. 3A). D-E. Phaenomenella nicoi Kantor, Kosyan, Sorokin \& Fedosov, 2020, D - holotype, South China Sea, SW off Dong Sha, ZHONGSHA 2015 st. CP4132, 2007'N, $116^{\circ} 22^{\prime} \mathrm{E}$, 958-988 m, MNHN IM-2013-61585 (shell, see Fig. 10E); E - South China Sea, ZHONGSHA 2015 st. CP4134, $19^{\circ} 50^{\prime} \mathrm{N}, 11^{\circ} 27^{\prime} \mathrm{E}, 1128-1278$ m, MNHN-IM-2013-61673. F. Siphonalia cassidariaeformis (Reeve, 1846), Japan, Off Hashima, Miyazaki Prefecture, Kyushu (after Kantor et al., 2020a: fig. 11A). Scale bars: A,B, D, E - $100 \mu \mathrm{m}, \mathrm{C}-50 \mu \mathrm{m}, \mathrm{F}-200 \mu \mathrm{m}$. 


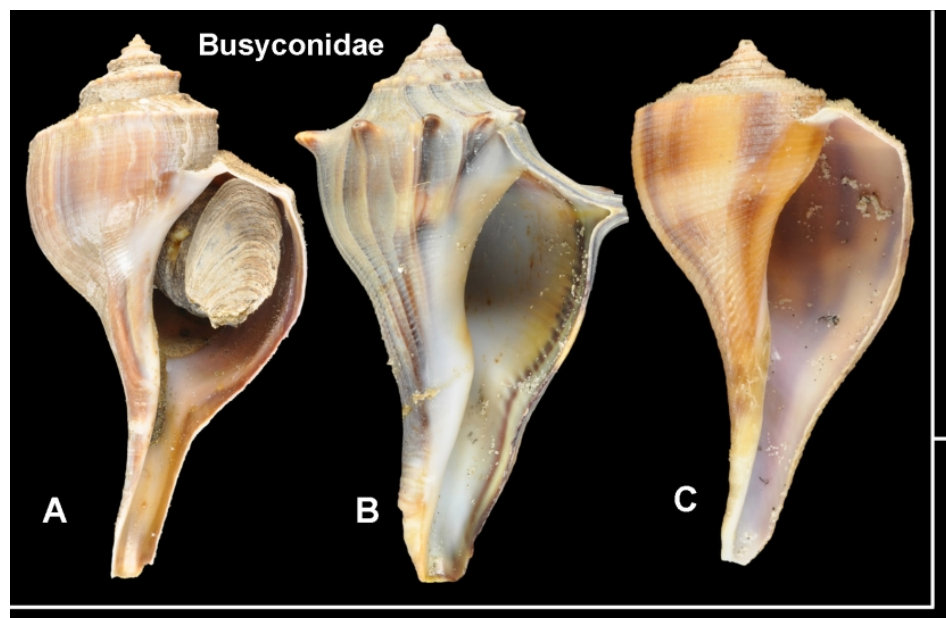

\section{Buccinanopsidae}
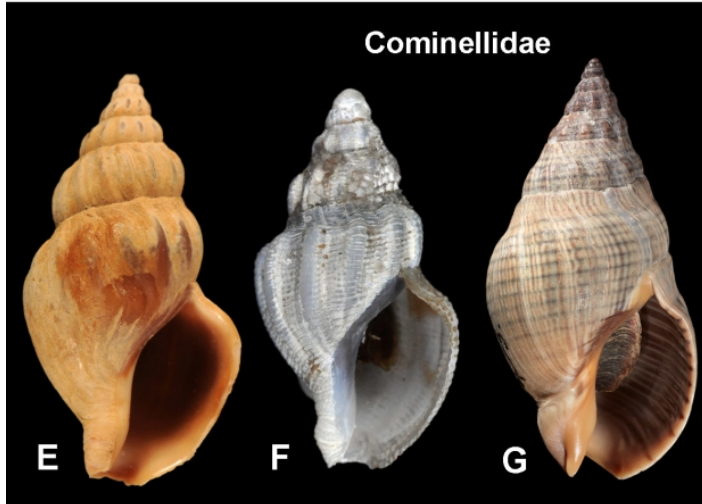

H
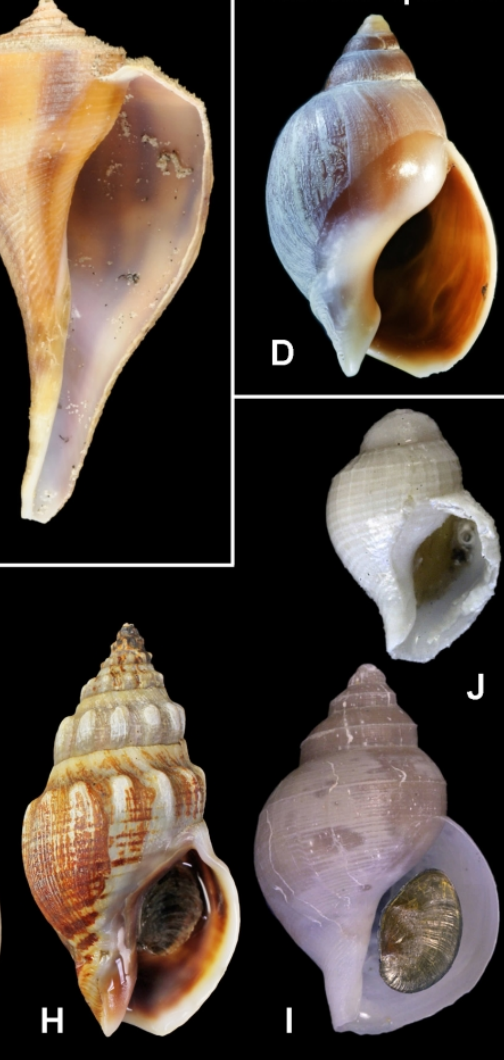

Retimohniidae
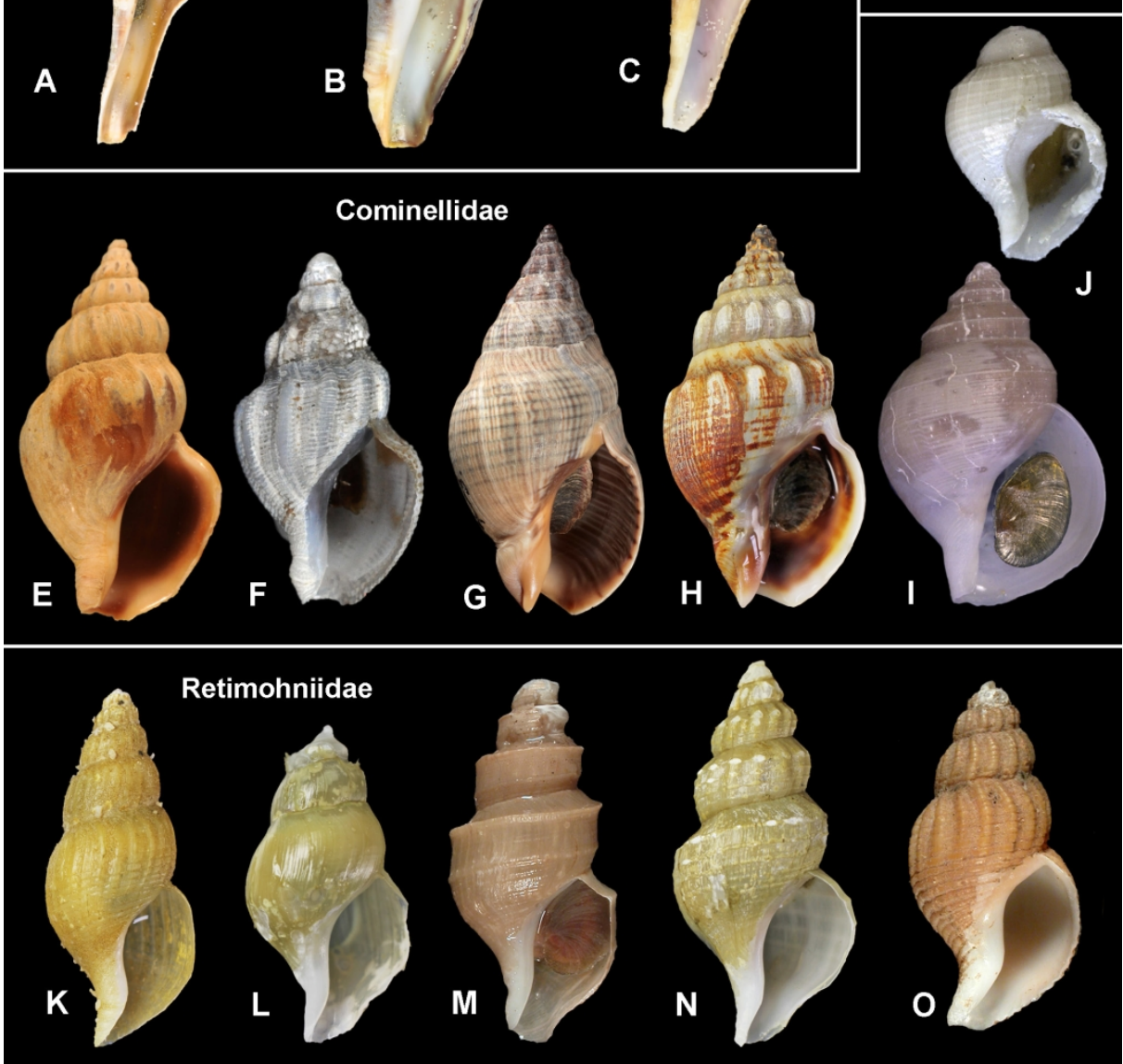

K

Figure 15. Shells of Busyconidae (A-C), Buccinanopsidae (D), Cominellidae (E-J), and Retimohniidae (K-O). A. Busycotypus canaliculatus (Linnaeus, 1758), USA, South Carolina, MNHN IM-2013-40689, sequenced specimen. B. Busycon carica (Gmelin, 1791), USA, South Carolina, MNHN IM-2013-40690, sequenced specimen. C. Fulguropsis pyruloides (Say, 1822), USA, South Carolina, MNHN IM-2013-40692, sequenced specimen. D. Buccinanops deformis (P. P. King, 1832), Argentina, Isla de los Pajaros, $42^{\circ} 25.4^{\prime} \mathrm{S}, 6^{\circ} 32.2^{\prime} \mathrm{W}$, intertidal, IEE uncatalogued, SL $27.7 \mathrm{~mm}$ (radula, see Fig. 16I). E. Pareuthria fuscata (Bruguière, 1789), Tierra del Fuego, San Sebastian Bay, 53⒗8'S, 68¹3.2'W, USNM 898376, SL 21.6 mm (photo USNM). F. Pareuthria turriformis Egorova, 1982, Antarctica, Ross Sea, 7119'S, 170³0'E, 243 m, MNA168, SL 16.1 $\mathrm{mm}$, sequenced specimen. G. Cominella virgata H. Adams \& A.Adams, 1853, New Zealand, Ahipara Bay, Reef Point, Te Papa Tongareva (M.278752), SL $31.3 \mathrm{~mm}$. H. Cominella glandiformis (Reeve, 1847), New Zealand, Mangere Inlet, SE of Auckland, 36 ${ }^{\circ} 56^{\prime} \mathrm{S}, 1^{\circ} 4^{\circ} 49^{\prime} \mathrm{E}$, AORI_YK\#3987, $25.6 \mathrm{~mm}$, sequenced

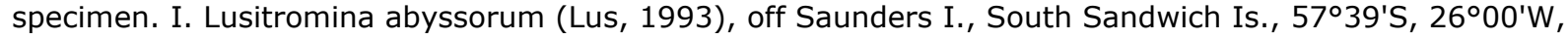
2380-2609 m, USNM 1010536, SL 29.2 mm (photo USNM) (radula, see Fig. 16E). J. Falsitromina bella

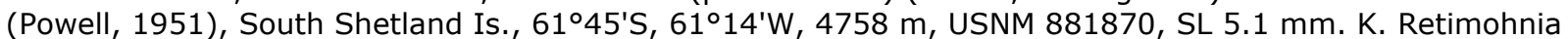


bella (Ozaki, 1958), Japan, off Tokachi, Hokkaido I., 42 $11^{\prime} \mathrm{N}, 144^{\circ} 11^{\prime} \mathrm{E}, 1210-1248 \mathrm{~m}$. AORI_YK\#3977, SL $24.5 \mathrm{~mm}$, sequenced specimen. L. Retimohnia micra (Dall, 1907), Japan, off Otsuchi, Iwate, Honshu I., $39^{\circ} 20^{\prime} \mathrm{N}, 142^{\circ} 23^{\prime} \mathrm{E}, 849-864 \mathrm{~m}$, AORI_YK\#3978, SL $11.7 \mathrm{~mm}$, sequenced specimen. M. Fusipagoda exquisita (Dall, 1913), Eastern Kamchatka, $55^{\circ} 52^{\prime} \mathrm{N}, 164^{\circ} 8^{\prime} \mathrm{E}, 4382 \mathrm{~m}$, R/V Vityaz sta. 524, SL $23.5 \mathrm{~mm}$ (radula, see Fig. 16G) (after Kosyan \& Kantor, 2015: fig. 1B). N. Fusipagoda sp., Japan, off Onagawa, Miyagi, Honshu I., 38 $16^{\prime} \mathrm{N}, 143^{\circ} 32^{\prime} \mathrm{E}, 3302-3311 \mathrm{~m}$, AORI_YK\#3981, SL $29.1 \mathrm{~mm}$, sequenced specimen. O. Retifusus jessoensis (Schrenck, 1863), Sea of Japan, Peter the Great Bay, ZIN 34121/16, SL $22.1 \mathrm{~mm}$ (radula, see Fig. 16H) (after Kosyan \& Kantor, 2014: fig. 1B). 

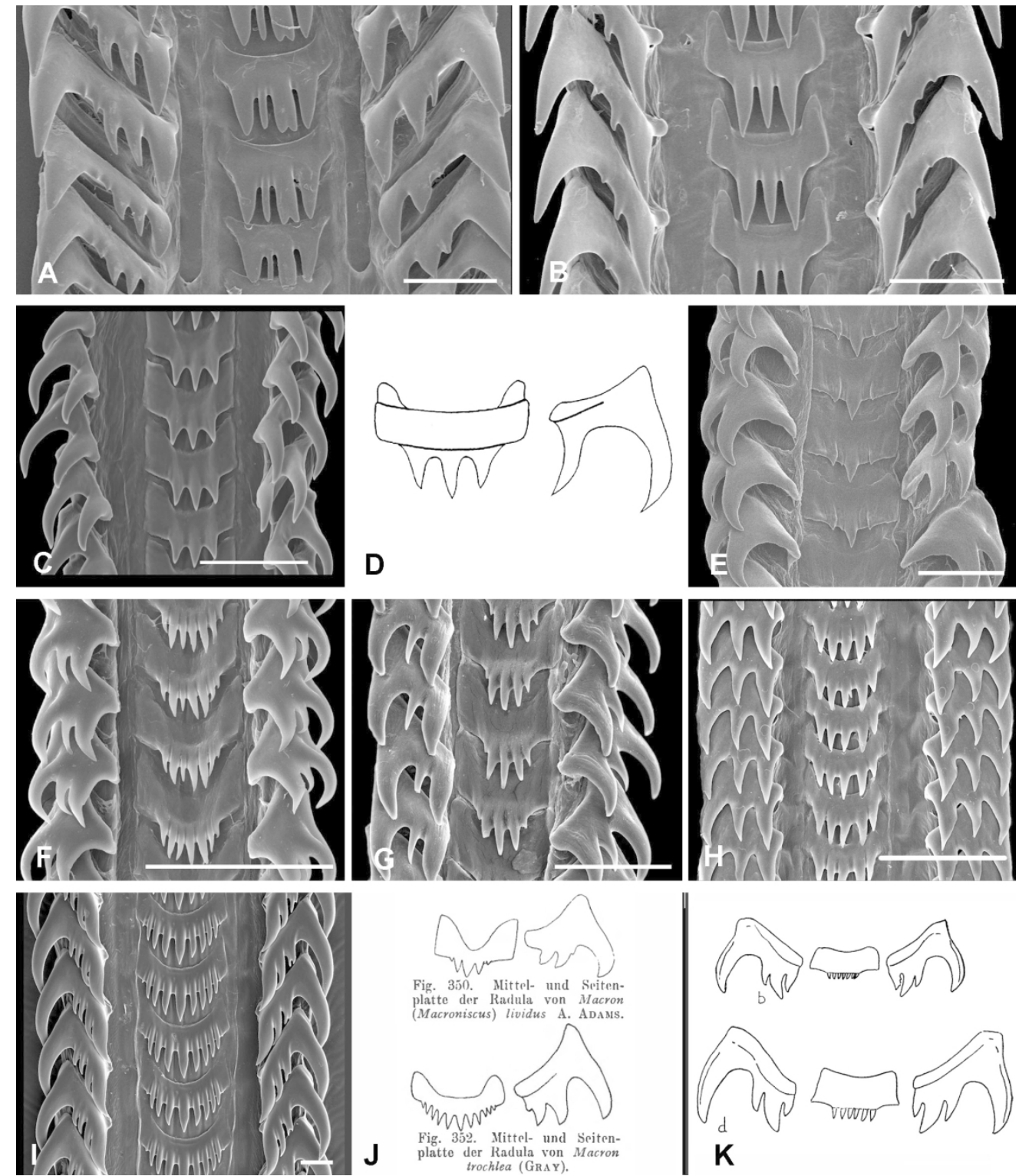

Figure 16. Radulae of Busyconidae (A-B), Cominellidae (C-E), Retimohniidae (F-H), Buccinanopsidae (I), and Buccinoidea insertae sedis (J-K). A. Busycon carica (Gmelin, 1791), USA, Lewes, Delaware (after Kosyan \& Kantor, 2004: fig. 11A). B. Fulguropsis spirata (Lamarck, 1816), Mexico, Yucatan (after Kosyan \& Kantor, 2004: fig. 11C). C. Pareuthria fuscata (Bruguière, 1789) (after Pastorino, 2016; photo G. Pastorino). D. Cominella virgata H. Adams \& A.Adams, 1853, New Zealand, Wellington Bay, New Zealand (after Cernohorsky, 1971: fig. 93). E. Lusitromina abyssorum (Lus, 1993), off Saunders I., South Sandwich Is., 5739'S, 2600'W, 2380-2609 m, SL 29.2 mm, USNM 1010536 (shell, see Fig 15I). F. Retimohnia micra (Dall, 1907), Sea of Japan, R/V Vityaz st. 7490, 3951'N, 13347'E, 560 m (after Kosyan \& Kantor, 2016 :

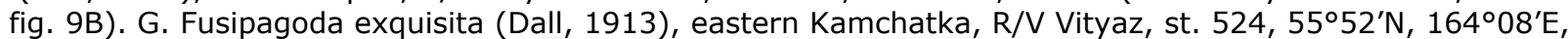
$4382 \mathrm{~m}$ (shell, see Fig. 15M) (after Kosyan \& Kantor, 2015: fig. 3A). H. Retifusus jessoensis (Schrenck, 1863 in 1862-63), Sea of Japan, Peter the Great Bay, ZIN 34121/16, SL $22.1 \mathrm{~mm}$ (shell, see Fig. 15O) (after Kosyan \& Kantor, 2014: fig. 4A). I. Buccinanops deformis (P. P. King, 1832), Argentina, Isla de los Pajaros, $42^{\circ} 25.4^{\prime} \mathrm{S}, 6^{\circ} 32.2^{\prime} \mathrm{W}$, intertidal, IEE uncatalogued (shell, see Fig. 15D). J. Macron spp. - (350) M. lividus (A.Adams, 1855); (352) Macron aethiops (Reeve, 1847) (after Thiele, 1929). K. Burnupena spp - (b) B. cincta (Röding, 1798); (d) Burnupena papyracea (Bruguière, 1789) (after Orr, 1956: fig. 1). 
Scale bars: A,B $-500 \mu \mathrm{m} ; C-80 \mu \mathrm{m} . \mathrm{E}, \mathrm{F}, \mathrm{G}, \mathrm{H}, \mathrm{I}-100 \mu \mathrm{m}$. $170 \times 199 \mathrm{~mm}(300 \times 300$ DPI) 


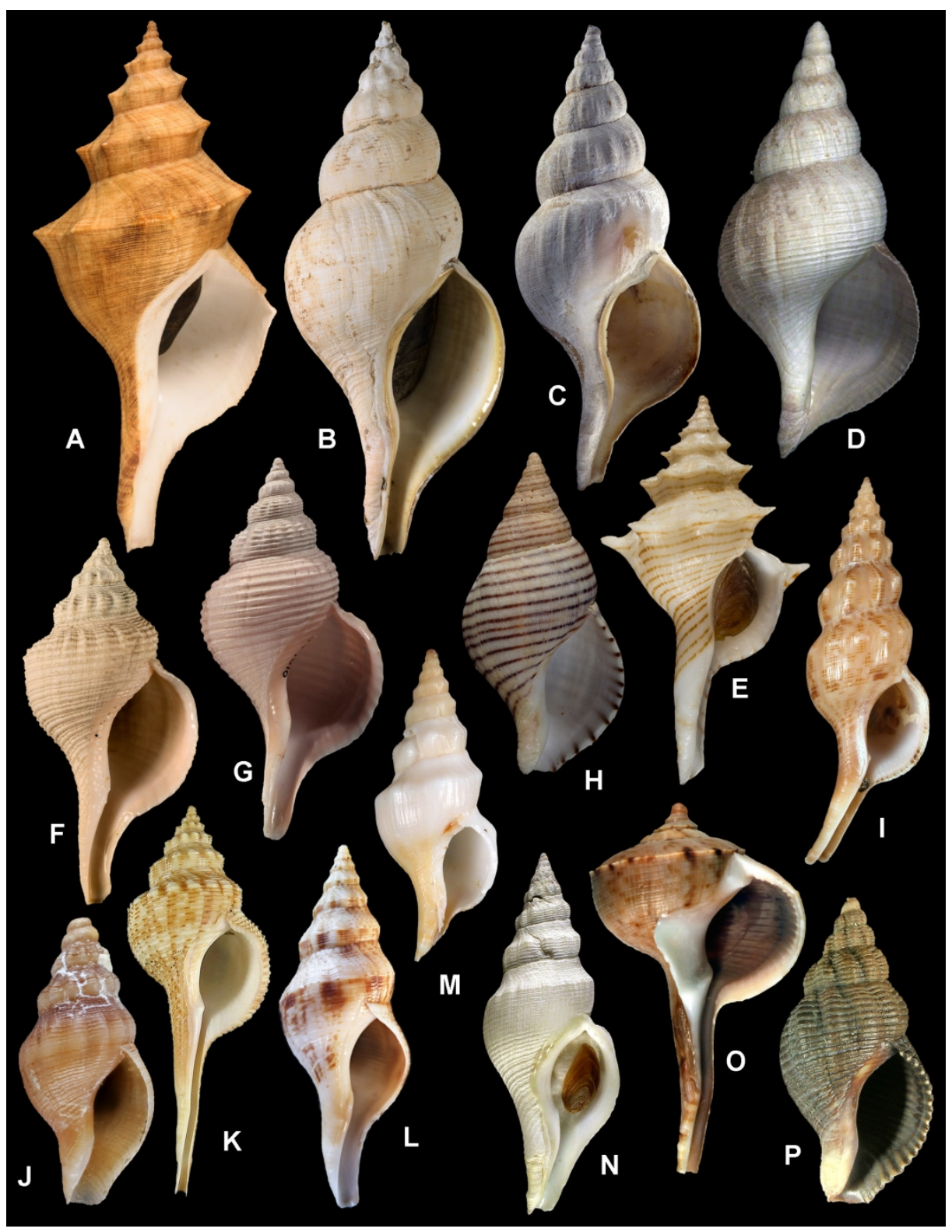

Figure 17. Shells of Austrosiphonidae (A-E) and Tudiclidae (F-P). A. Penion cuvierianus (Powell, 1927), New Zealand, off White I., NMNZ M.132414. B. Penion chathamensis Powell, 1938, New Zealand, E of Mernoo Bank, Chatham Rise, NMNZ M.118863. C. Antarctoneptunea benthicola (Dell, 1956), New Zealand, Chatham Rise, NMNZ M.009775, SL 95 mm. D. Antarctoneptunea aurora (Hedley, 1916), Antarctica, 7700'S, 16159'W, 525-537 m, USNM 898682, SL 68.9 mm (photo USNM). E. Serratifusus lineatus Harasewych, 1991, holotype, New Caledonia, Grand Passage, 1855'S, 163⒉'E, 460 m, MNHN IM-2000-6527, SL 35.5 $\mathrm{mm}$. F. Aeneator recens (Dell, 1951), New Zealand, NE slope of Mernoo Bank, Chatham Rise, NMNZ M.127027. G. Aeneator benthicolus Dell, 1963, New Zealand, off Cape Kidnappers, NMNZ M.147010. H. Buccinulum linea (Martyn, 1784), neotype, New Zealand, head of Titirangi Bay, NE of Havelock, NMNZ M.046477, SL 35.4 mm. I. Euthria walleri (Ladd, 1976), Vanuatu, 15³3'S, 167¹7'E, 120-156 m, MNHN IM2007-32887, SL 57.5 mm, sequenced specimen. J. Tasmeuthria clarkei (Tenison Woods, 1876), Western Australia, Esperance, Woody I., 3358'S, $122^{\circ} 01^{\prime} \mathrm{E}, 11 \mathrm{~m}, \mathrm{MNHN}$ IM-2013-63028, SL 9.9 mm, sequenced specimen (radula, see Fig. 18K). K. Afer cumingii (Reeve, 1848), Taiwan, SL 88.9 mm, () Guido \& Philippe

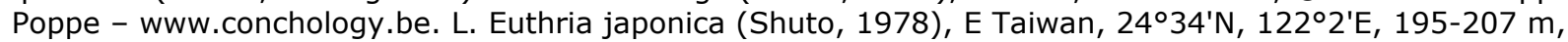


IM-2013-78127, sequenced specimen (radula, see Fig. 18J). M. Euthria cummulata Fraussen \& Hadorn, 2003, New Caledonia, Norfolk Ridge, 2317'S, $168^{\circ} 14^{\prime} E$, 275-348 m, IM-2007-34931, SL 46.2 mm, sequenced specimen. N. Euthriostoma saharicum (Locard, 1897), Western Sahara, (c) Guido \& Philippe Poppe - www.conchology.be. O. Tudicla spirillus (Linnaeus, 1767), trawled between Porto Novo and Pondicherry, India, 13-15 m, USNM 894130, SL 76.7 mm (after Harasewych, 2018). P. Lirabuccinum dirum (Reeve, 1846), USA, SL 26 mm, (c) Guido \& Philippe Poppe - www.conchology.be.

$170 \times 219 \mathrm{~mm}(300 \times 300 \mathrm{DPI})$ 

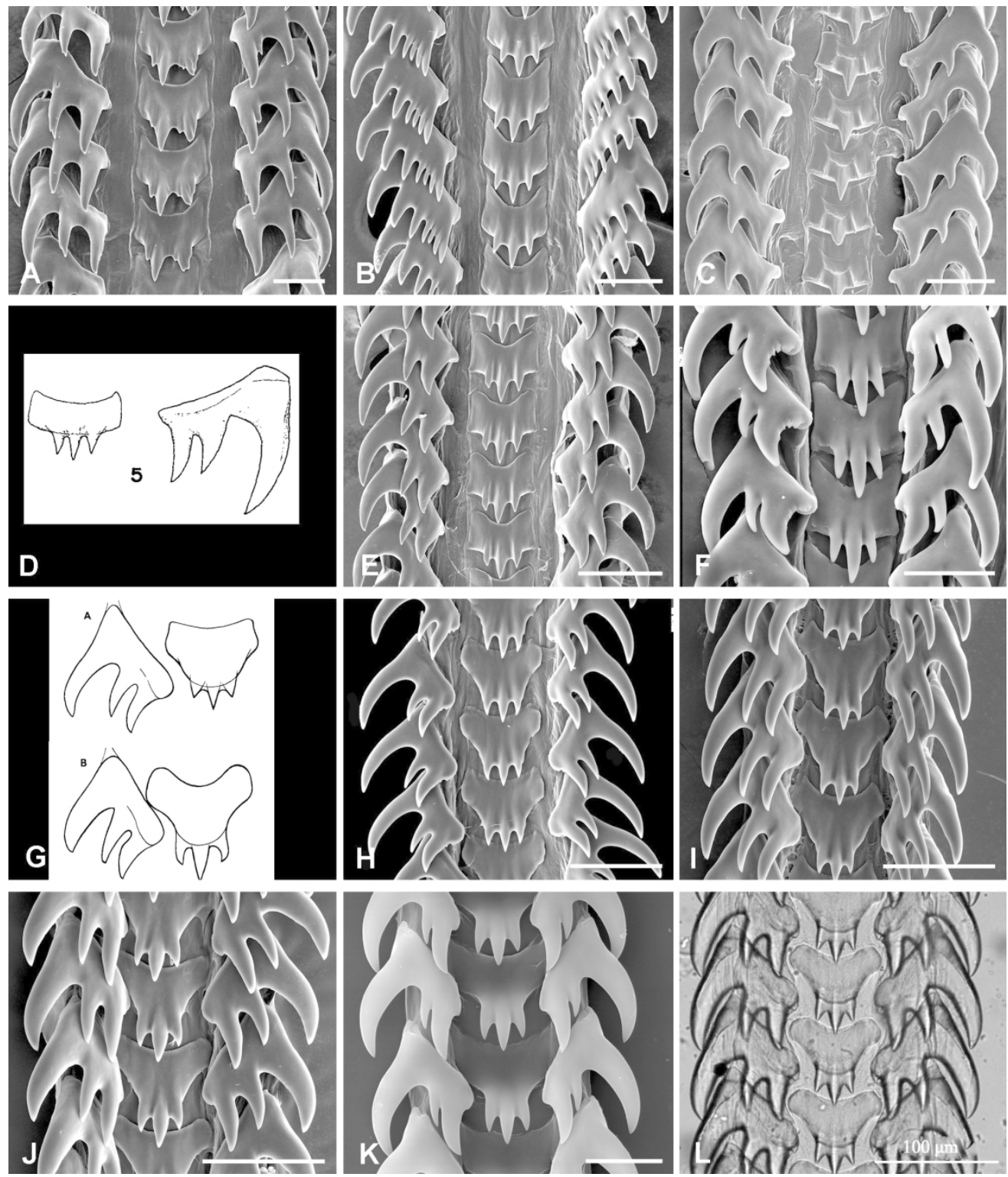

Figure 18. Radulae of Austrosiphonidae (A-F) and Tudiclidae (G-P). A. Antarctoneptunea aurora (Hedley, 1916), Antarctica, Adélie Land, 66³4'S, 145²1'E, 401-416 m, MNHN IM- 2009-7893. B. Antarctoneptunea benthicola (Dell, 1956), New Zealand, 48049'S, 167027'E, 560 m, MNNZ M.95190. C. Antarctoneptunea benthicola (Dell, 1956), New Zealand, 43003.7'S, 177000'E, 350 m, MNNZ M.117007. D. Kelletia lischkei Kuroda, 1938 (after Kang, 1976). E. Penion cuvierianus (Powell, 1927), New Zealand, Peach Cove, Bream Bay, Northland, 35051.9'S, 174034.1'E, 24 m, NMNZ M.98018. F. Serratifusus lineatus Harasewych, 1991, northern New Caledonia, $18^{\circ} 59^{\prime} \mathrm{S}, 163^{\circ} 24^{\prime} \mathrm{E}, 320-335$ m, MNHN IM-2007-34666 (sequenced specimen). G. Aeneator spp. (A) Aeneator elegans (Suter, 1917), st. VUZ83, off Palliser Bay, 1000 m, NMNZ M.11115; (B) A. valedictus (R. B. Watson, 1886), Chatham Islands Expedition st. 6, Chatham Rise, 400 m, NMNZ (after Beu, 1979). H. Buccinulum linea (Martyn, 1784), New Zealand, NMNZ. I. Euthria cornea (Linnaeus, 1758), Mediterranean, Capri I., IEE uncatalogued. J. Euthria japonica (Shuto, 1978), E Taiwan, $24^{\circ} 34^{\prime} \mathrm{N}, 1^{\prime 2} 2^{\circ} 02^{\prime} \mathrm{E}$, 195-207 m, IM-2013-78127 (shell, see Fig. 17L). K. Tasmeuthria clarkei (Tenison Woods, 1876), Western

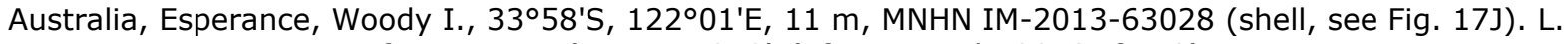
Afer cumingii (Reeve, 1848) (after Li et al., 2013: fig. 2). Scale bars: A,B,H-J - $100 \mu \mathrm{m} ; \mathrm{C}, \mathrm{E}, \mathrm{K}-250 \mu \mathrm{m} ; \mathrm{F}-50 \mu \mathrm{m}$ 
Figure 19. Shells of Prodotiidae fam. nov. (A-I). A. Clivipolia pulchra (Reeve, 1846), Philippines, Pamilacan I., $09^{\circ} 29.4^{\prime} \mathrm{N}, 1^{\circ} 3^{\circ} 5.0^{\prime} \mathrm{E}, 17 \mathrm{~m}$, MNHN IM-2007-32529, SL $22.4 \mathrm{~mm}$, sequenced specimen. B. Caducifer decapitatus (Reeve, 1844), Vanuatu, 15³3.0'S, 16709.6'E, 20 m, MNHN IM-2007-32728, SL 13 mm, sequenced specimen. C. Caducifer decapitatus (Reeve, 1844), Papua-New Guinea, Madang lagoon, S Sek I., 0506.4'S, 14549'21.2'E, MNHN IM-2013-18102, SL 8.3 mm (young specimen with intact spire). D-E.

Prodotia lannumi (Schwengel, 1950), Vanuatu, Santo, south of Aoré I., 15³6.6'S, 167010.0'E, 10-18 m, D - MNHN IM-2007-32839, SL 11.6 mm, sequenced specimen; E - MNHN IM-2007-32859, SL $14.1 \mathrm{~mm}$. F.

Enzinopsis contracta Reeve, 1846 (holotype of Engina gannita Hedley, 1914), Australia, Queensland, Torres Strait, Darnley I., AMS C.7468, SL 17.2 mm. G. Speccapollia africana Fraussen \& Stahlschmidt, 2016, holotype, Mozambique, Nacala Bay, 3-5 m, MNHN IM- 2000-31691, SL 10 mm. H. Minioniella heleneae Fraussen \& Stahlschmidt, 2016, holotype, Tuamotu Islands, IM- 2000-31692, SL $6.7 \mathrm{~mm}$. I. Prodotia iostoma (Gray, 1833), New Caledonia, Koumac, KOUMAC 2.3 st. KB617, 2044,7'S, 164²15, 8'E, 13 m, SL $22.1 \mathrm{~mm}$ (radula, see Fig. 20D).

$170 \times 136 \mathrm{~mm}(300 \times 300 \mathrm{DPI})$ 

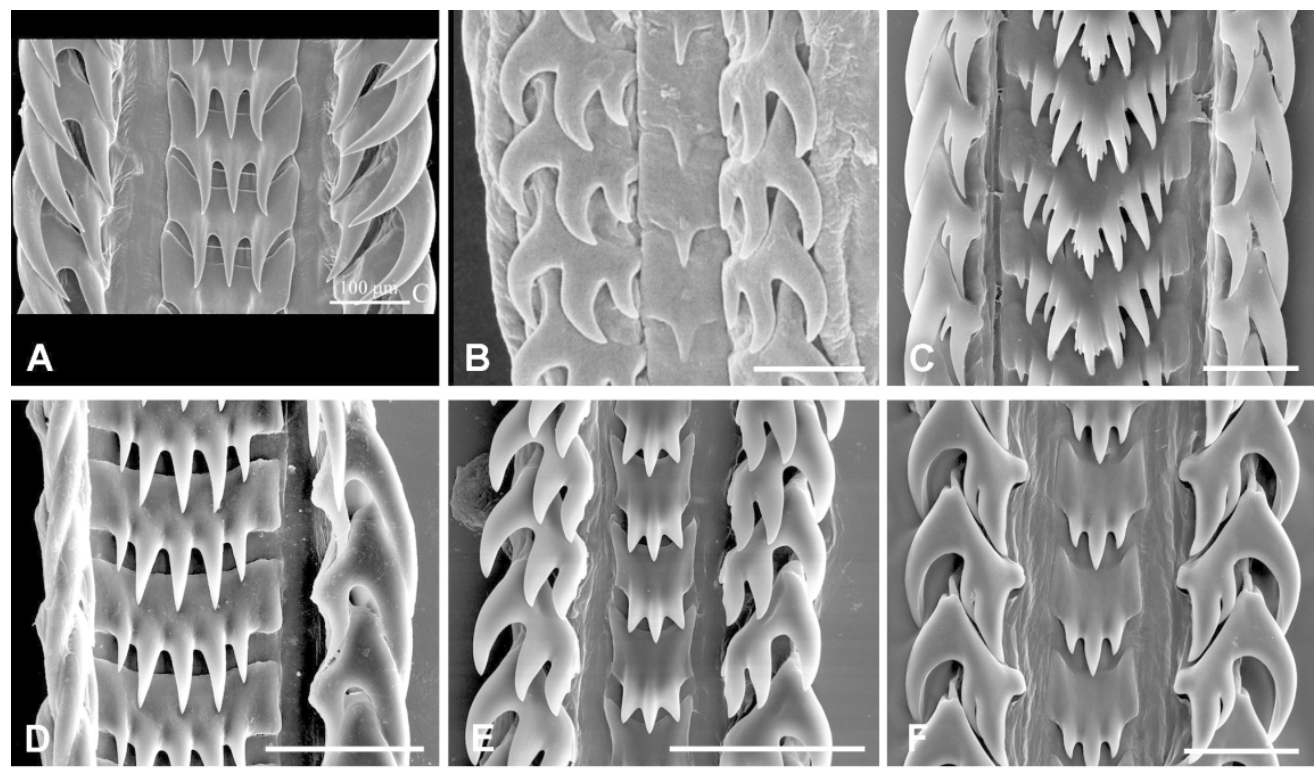

Figure 20. Radulae of Melongenidae (A), Chauvetiidae fam. nov. (B) and Prodotiidae fam. nov. (C-F) A. Volegalea cochlidium (Linnaeus, 1758), Vietnam, Haiphong, fishermen market (after Kosyan \& Kantor. 2004: fig. 3C, as Pugilina pugilina (Born, 1778)). B. Chauvetia mamillata (Risso, 1826) (after Gofas \& Oliver, 2010: fig. 2). C. Prodotia lannumi (Schwengel, 1950), New Ireland, Kavieng. D. Prodotia iostoma (Gray, 1833), New Caledonia, Koumac, KOUMAC 2.3 st. KB617, 2044.7'S, 164²15.8'E, 13 m (shell, see Fig. 19I). E. Clivipollia pulchra (Reeve, 1846), New Caledonia, Grand récif de Koumac, KOUMAC 2.3 st. KL39, 2045.1'S, 164¹4.0'E, 26 m, MNHN IM-2019-8415. F. Caducifer decapitatus (Reeve, 1844), New Caledonia, Grand récif de Koumac, KOUMAC 2.3 st. KB645, 2040.5'S, 164¹3.0'E, 16 m, MNHN IM-2019-9119. Scale bars: $A-100 \mu \mathrm{m}, \mathrm{B}-10 \mu \mathrm{m} ; \mathrm{C}-20 \mu \mathrm{m} ; \mathrm{D}, \mathrm{E}, \mathrm{F}-50 \mu \mathrm{m}$ 


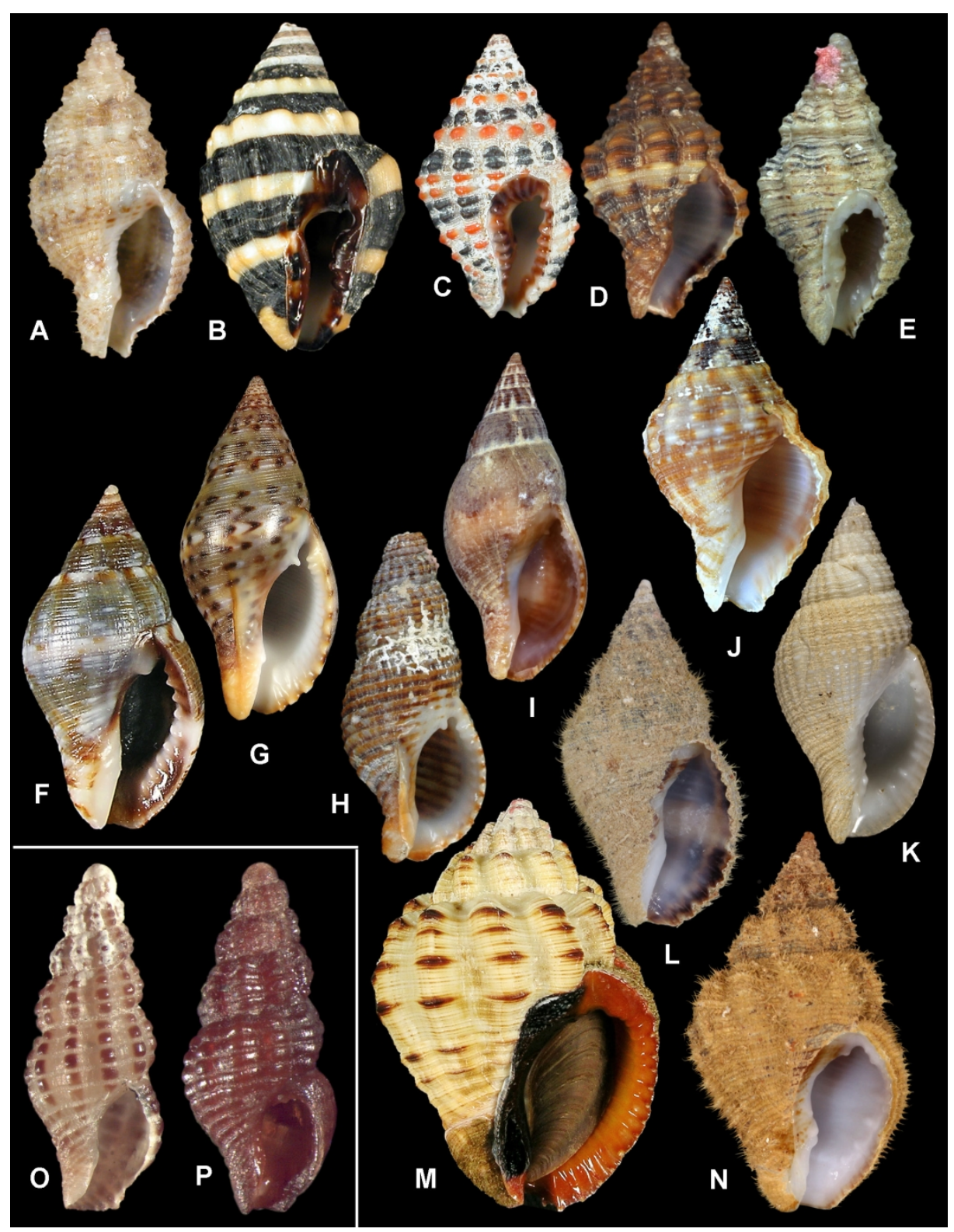

Figure 21. Shells of Pisaniidae (A-N) and Chauvetiidae fam, nov. (O-P). A. "Engina" egregia (Reeve, 1844), Vanuatu, Santo, SE Aesi I., 15²6.9'S, 167015.8'E, $11 \mathrm{~m}$, IM-2007-32918, SL $14 \mathrm{~mm}$, sequenced specimen. B. Engina mendicaria (Linnaeus, 1758), Vanuatu, S coast of Santo I., $15^{\circ} 34.9^{\prime} \mathrm{S}, 167^{\circ} 02.4^{\prime} \mathrm{E}, 0-1 \mathrm{~m}, \mathrm{MNHN}$ IM-2007-32893, SL 15.9 mm. C. Engina alveolata (Kiener, 1836), Vanuatu, Santo, E. of Malo I., 1543.4'S, $167^{\circ} 15.0^{\prime} E, 6$ m, MNHN IM-2007-32919, SL $12.4 \mathrm{~mm}$, sequenced specimen. D. Hesperisternia karinae

(Nowell-Usticke, 1959), Guadeloupe, 16²4'N, 6052'W, 72 -111 m, MNHN IM-2013-60604, sequenced specimen. E. "Engina" corinnae Crovo, 1971, Martinique, Ste Luce, Grand Caye, 14²7.3'N, 6055.5'W, 15 m, MNHN IM-2013-70604, SL 9.3 mm, sequenced specimen. F. Pisania striata (Gmelin, 1791), Greece, SL 16.5 mm, (c) Guido \& Philippe Poppe - www.conchology.be. G. "Pisania" pusio (Linnaeus, 1758),

Guadeloupe, SL 34.2 mm, (c) Guido \& Philippe Poppe - www.conchology.be. H. "Pisania" decollata (G.B.

Sowerby I, 1833), Papua New Guinea, 05¹1'S, 14550'E, 5 m, MNHN IM-2013-18270, SL 20.7 mm, sequenced specimen. I. "Pisania" ignea (Gmelin, 1791), N Madagascar, 25¹7'S, 46³1'E, 53-54 m, MNHN IM-2009-14631, sequenced specimen. J. Gemophos tinctus (Conrad, 1846), Guadeloupe, $16^{\circ} 20^{\prime} \mathrm{N}, 6^{\circ} 32^{\prime} \mathrm{W}$ $1 \mathrm{~m}$, MNHN IM-2013-8012, SL 16.4 mm, sequenced specimen. K. Cancellopollia gracilis Vermeij \& Bouchet, 
1998, holotype, New Caledonia, Norfolk Ridge, 435 m, MNHN IM-2000-6329, SL 29.8 mm. L. Pollia fumosa

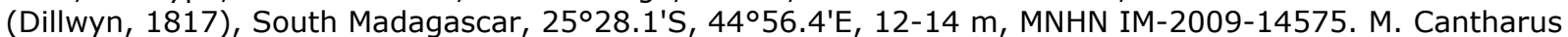
melanostoma (G.B. Sowerby I, 1825), Philippines, SL 59.2 mm@ Guido \& Philippe Poppe -

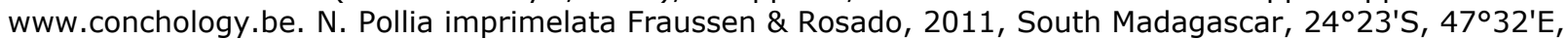
154-168 m, IM-2009-14603, sequenced specimen. O. Chauvetia mamillata (Risso, 1826), Spain, Malaga, 05 m, IEE BUC 193, SL 5.5 mm. P. Chauvetia procerula (Monterosato, 1889), Spain, Malaga, 0-5 m, IEE BUC 210, SL $4.2 \mathrm{~mm}$

$170 \times 219 \mathrm{~mm}(300 \times 300 \mathrm{DPI})$ 
Figure 22. Radulae of Pisaniidae. A. Pisania striata (Gmelin, 1791), Mediterranean (after Troschel, 1867, pl. 7, fig. 2). B. "Pisania" decollata (G.B. Sowerby I, 1833), New Caledonia, Koumac, MNHN unregistered. C. "Pisania" fasciculata (Reeve, 1846), New Caledonia, Koumac, KOUMAC 2.3 st. KB517, 20³7.6'S, 164¹7.3'E, 0 m, MNHN unregistered. D. "Pisania" (= Ecmanis) ignea (Gmelin, 1791) (after Ponder, 1972: text fig. 2). E. Engina turbinella (Kiener, 1836), French Guiana, 05¹7.5'N, 52³5.2'W, 7 m, MNHN IM-201357184 (sequenced specimen). F. Engina mendicaria (Linnaeus, 1758), Papua New Guinea, Laing I., IEE unregistered. G. Pollia fumosa (Dillwyn, 1817), Vietnam, Nha-Trang Bay, Mun I., IEE unregistered. H. Pollia undosa (Linnaeus, 1758), Vietnam, Nha-Trang Bay, Mun I., IEE unregistered. I. "Engina" egregia (Reeve, 1844), Papua New Guinea, Madang Lagoon, 05¹3.8'S, 14548.0'E, 15 m, MNHN IM-2013-12540. Scale bars: B, C, G, H - $100 \mu \mathrm{m} ; \mathrm{E}, \mathrm{F}-20 \mu \mathrm{m}, \mathrm{I}-50 \mu \mathrm{m}$. 
Figure 23. Shells of Nassariidae. Cylleninae: A. Cyllene owenii Gray, 1834 (syntype of Cyllene senegalensis Petit de la Saussaye, 1853), Senegal, MNHN IM-2000-6364, SL 16 mm. B. Cyllene parvula Bozzetti, 2014, Madagascar, holotype, MNHN IM-2000-27891, SL 12.5 mm. C. Neoteron ariel (Pilsbry \& Lowe, 1932), holotype, ANSP 155564, Nicaragua, SL $6.5 \mathrm{~mm}$ (photo ANSP). Tomliniinae: D. Nassaria acuminata (G.B. Sowerby III, 1913), Vanuatu, 153' S, 167015'E, 140-153 mm, MNHN IM-2007-32730, SL 23.6 mm, sequenced specimen. E. Tomlinia frausseni Thach, 2014, Vietnam, MNHN IM-2013-53362. Bulliinae: F. Bullia perlucida Bozzetti, 2014, holotype, Madagascar, MNHN IM-2000-27493, SL 19.9 mm. Dorsaninae: G. Dorsanum miran (Bruguière, 1789), Senegal, SL 22.5 mm, (c) Guido \& Philippe Poppe - www.conchology.be. Anentominae: H. Oligohalinophila dorri (Wattebled, 1886), syntype, MNHN IM-2000-6321, Vietnam, lagune de Koa-hai, SL 13.9 mm. I. Anentome sp. D, Vietnam, vicinities of Nha-Trang city, middle part of Kai river, IM-2009-29658, sequenced specimen. Nassariinae: J. Naytia glabrata (G.B. Sowerby II, 1842), Cameroon, SL 7.2 mm, (c) Guido \& Philippe Poppe - www.conchology.be. K. Phrontis complanata (Powys, 1835), Costa Rica, SL $7.1 \mathrm{~mm}$, (c) Guido \& Philippe Poppe -www.conchology.be. Photinae: L. Engoniophos unicinctus (Say, 1826) (syntype of Nassa guadelupensis Petit de la Saussaye, 1852), Guadeloupe, MNHN IM-2000-6713, SL 
$27.1 \mathrm{~mm}$. M. Antillophos candeanus (d'Orbigny, 1842) (syntype of Phos antillarum Petit de la Saussaye, 1853), Guadeloupe, MNHN IM-2000-6584, SL 28.5 mm. N. Phos senticosus (Linnaeus, 1758), Papua New Guinea, Laing I., intertidal, SL 33.5 mm (radula, see Fig. 24G). O. Northia pristis (Deshayes, 1844), Panama, Venado I., intertidal, IEE BUC YK1 (radula, see Fig. 24F). 

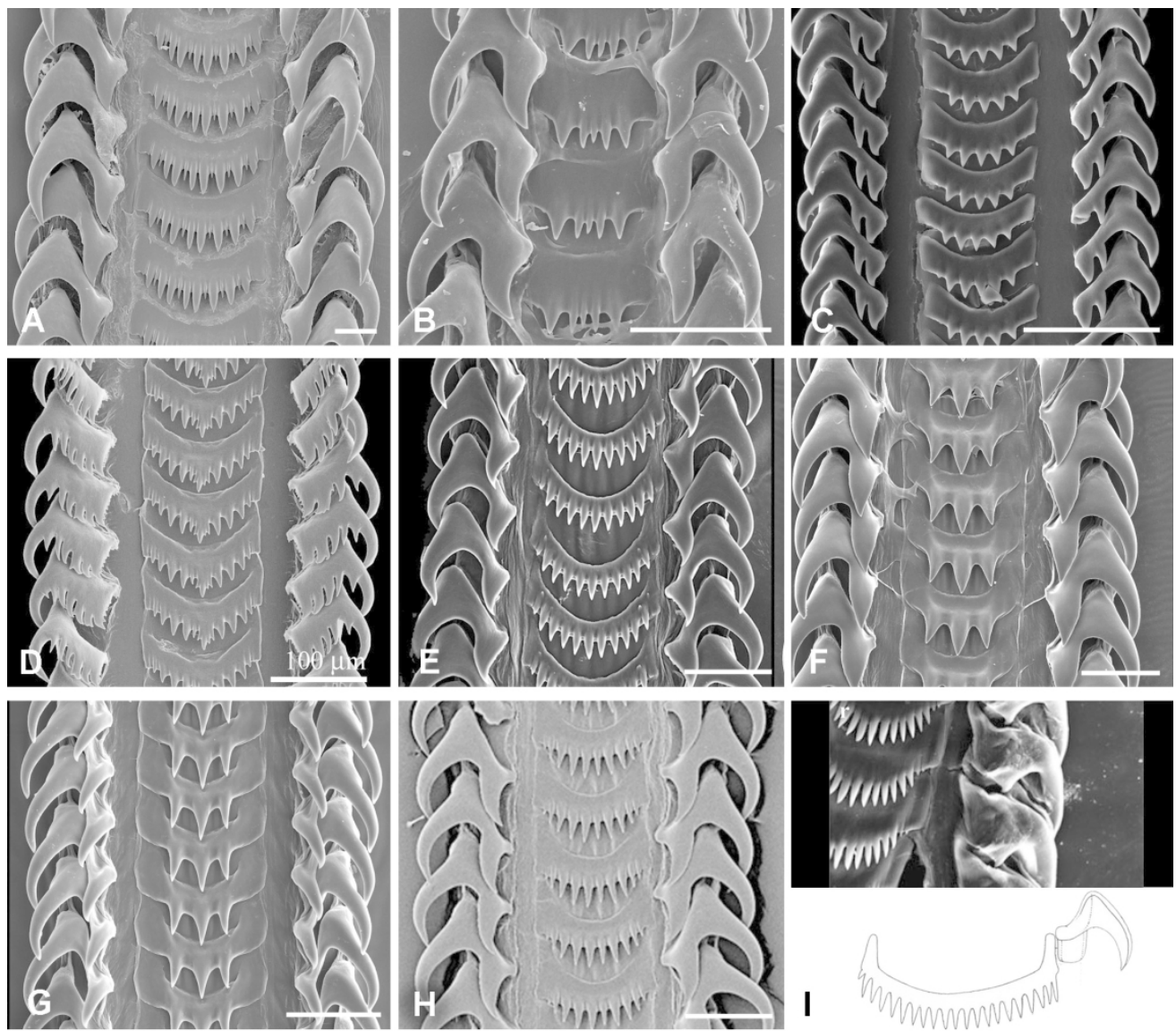

Figure 24. Radulae of Nassariidae. A. Tomlinia frausseni Thach, 2014, Vietnam, MNHN. B. Nassaria sp., Bismarck Sea, W Kairiru I., 0320'S, $143^{\circ} 28^{\prime} E$, 325-345 m, PAPUA NIUGINI st. CP4048, MNHN IM-201318779. C. Anentome sp. D, Vietnam, vicinities of Nha-Trang city, middle part of Kai river, MNHN IM-200929661. D. Oligohalinophila dorri (Wattebled, 1886), Vietnam (after Kantor \& Kilburn, 2001: fig. 18). E. Tritia reticulata (Linnaeus, 1758), Black Sea, Gelendzhik, IEE uncatalogued. F. Northia pristis (Deshayes, 1844),

Panama, Venado I., intertidal, IEE BUC YK1 (shell, see Fig. 21M). G. Phos senticosus (Linnaeus, 1758), Papua-New Guinea, Laing Id., intertidal, IEE uncatalogued, SL $33.5 \mathrm{~mm}$ (shell, see Fig. 21L). H. Engoniophos unicinctus (Say, 1826) (after Abbate et al., 2018: fig. 5). I. Radulae of Nassariidae, Cylleninae. Upper panel - Cyllene fuscata A.Adams, 1851 (after Yang \& Zang, 2011: pl. 1r). lower panel - Neoteron ariel (Pilsbry \& Lowe, 1932), after D'Attilio (1981). Scale bars: A-E, G, I - $100 \mu \mathrm{m}, \mathrm{F}-200 \mu \mathrm{m}$. 